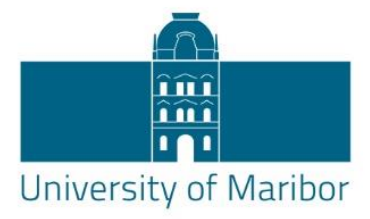

Faculty of Economics and Business

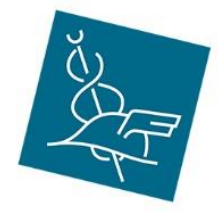

\title{
Proceedings of the 1ST International Scientific Conference »Teaching Methods for Economics and Business Sciences«
}

\section{May 2017, Maribor, Slovenia}

\section{Editor:} mag. Nataša Gajšt 


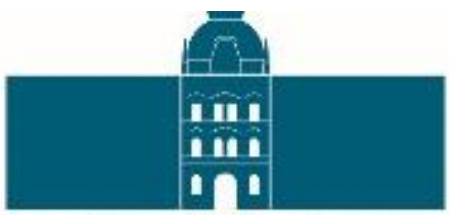

University of Maribor Press 


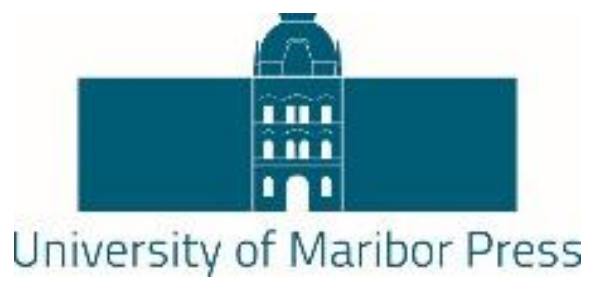

\section{Proceedings of the $1^{\text {ST }}$ International Scientific Conference »Teaching Methods for Economics and Business Sciences« \\ 8 May 2017, Maribor, Slovenia}

Editor:

mag. Nataša Gajšt 
Title: Proceedings of the $1^{\text {ST }}$ International Scientific Conference $»$ Teaching Methods for Economics and Business Sciences«

Subtitle: 8 May 2017, Maribor, Slovenia

Editor: Mag. Nataša Gajšt (University of Maribor, Faculty of Economics and Business)

Review: Assoc. Prof. Dr. Darja Boršič (University of Maribor, Faculty of Economics and Business), Assoc. Prof. Dr. Petya Dankova (University of Economics Varna), Assist. Prof. Dr. Anita Radman Peša (University of Zadar, Department of Economics), Assist. Prof. Dr. Tjaša Štrukelj (University of Maribor, Faculty of Economics and Business), Assist. Prof. Dr. Igor Todorović (University of Banja Luka, Faculty of Economics).

Tehnical Editor : Jan Perša (University of Maribor Press)

All graphic material: Authors of proceedings

Cover design: Jan Perša (University of Maribor Press)

Design and Layout: University of Maribor Press

Programme Committee: Assoc. Prof. Dr. Darja Boršič (University of Maribor, Faculty of Economics and Business), Assoc. Prof. Dr. Petya Dankova (University of Economics Varna), Mag. Igor Đukanović (University of Maribor, Faculty of Economics and Business), Mag. Nataša Gajšt (University of Maribor, Faculty of Economics and Business), Asist. Dr. Magdalena Graczyk-Kucharska, BA (Poznań University of Technology), Assist. Prof. Dr. Romana Korez Vide (University of Maribor, Faculty of Economics and Business), Assist. Prof. Dr. Anita Radman Peša (University of Zadar, Department of Economics), Mag. Alenka Plos (University of Maribor, Faculty of Economics and Business), Assist. Prof. Dr. Tjaša Štrukelj (University of Maribor, Faculty of Economics and Business), Assist. Prof. Dr. Igor Todorović (University of Banja Luka, Faculty of Economics), Prof. Dr. Zdenka Ženko (University of Maribor, Faculty of Economics and Business), Assist. Prof. Dr. Ewa Wiecek-Janka (Poznań University of Technology).

Organizing Committee: Assoc. Prof. Dr. Darja Boršič (University of Maribor, Faculty of Economics and Business), Mag. Nataša Gajšt (University of Maribor, Faculty of Economics and Business), Mag. Sanja Kocijan (University of Maribor, Faculty of Economics and Business), Mag. Alenka Plos (University of Maribor, Faculty of Economics and Business), Klemen Zapečnik (University of Maribor, Faculty of Economics and Business).

First published in 2017 by University of Maribor Press Slomškov trg 15, 2000 Maribor, Slovenia tel. +3862 25042 42, fax +38622523245 http://press.um.si, zalozba@um.si

\section{Co-published by}

University of Maribor, Faculty of Economics and Business

Razlagova ulica 14, 2000 Maribor, Slovenia

phone +38622290000, fax +38622290217

http://www.epf.um.si, epf@um.si 


\section{Publication type: e-publication}

Published: September 2017

\section{(C) University of Maribor Press}

All rights reserved. No part of this book may be reprinted or reproduced or utilized in any form or by any electronic, mechanical, or other means, now known or hereafter invented, including photocopying and recording, or in any information storage or retrieval system, without permission in writing from the publisher.

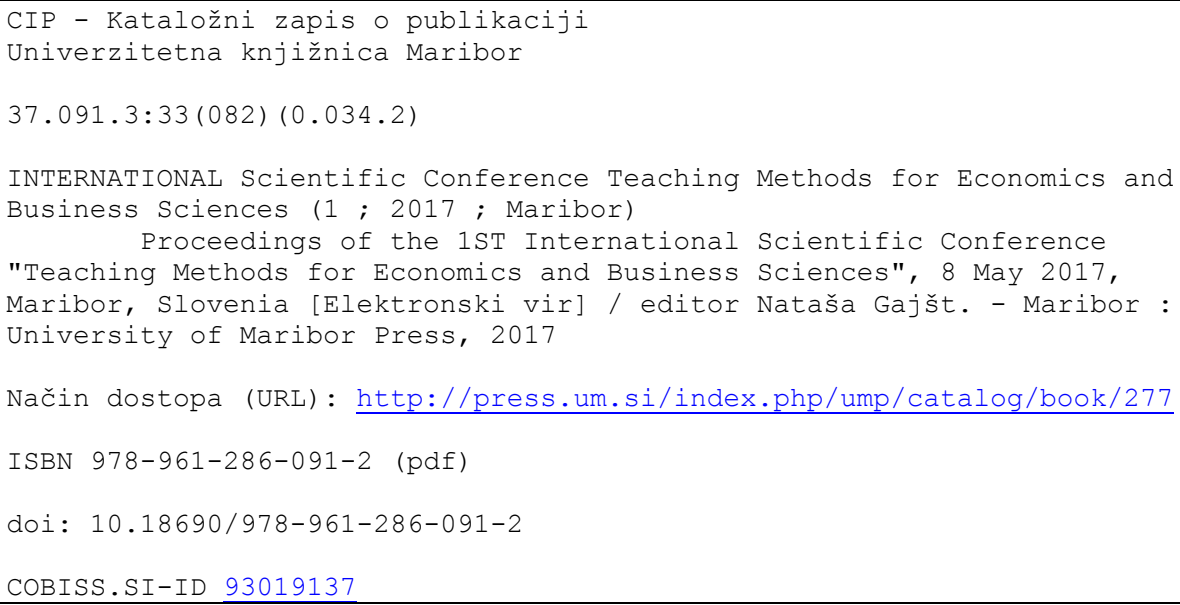

ISBN 978-961-286-091-2 (PDF)

DOI: https://doi.org/10.18690/978-961-286-091-2

Price: Free copy

For publisher: Full Prof. Dr. Igor Tičar, Rector (University of Maribor) 


\title{
$1^{\text {ST }}$ International Scientific Conference »Teaching Methods for Economics and Business Sciences«
}

\begin{abstract}
NATAŠA GAJŠT
Teaching is a challenging but also a rewarding profession. It is underpinned by one key question: how do we build a good teaching and learning environment so that our students can acquire professional competences which will enable them to be successful in today's global business environment.

These proceedings include the papers presented at the $1^{\text {st }}$ International Scientific Conference »Teaching Methods for Economics and Business Sciences« held on 8 May 2017 at the University of Maribor, Faculty of Economics and Business. The papers address students' learning outcomes, the development and measurement of students' professional and transversal competences and skills, creative teaching and learning techniques such as brainstorming and creative problem solving, active learning and collaborative learning, students' self-assessment of their learning, experiential learning and lifelong learning, practical teaching methods such as business simulations, action-based learning and knowledge integration, innovations and sustainability of different teaching methods, non-formal learning and teaching activities for vocational competences development, ethical aspects of creating a good student environment, capacity building, students' learning styles, teaching styles, students' creativeness, and, last but not least, students' academic success and their personal wellbeing.
\end{abstract}

These papers provide valuable insights into academic teaching practice and contribute to the answer to the above question.

Keywords: • teaching methods $\bullet$ economics and business $\bullet$ international conference $\bullet$ higher education $\bullet$ students $\bullet$

CORRESPONDENCE ADDRESS: mag. Nataša Gajšt, Lecturer in English, University of Maribor, Faculty of Economics and Business, Razlagova ulica 14, 2000 Maribor, Slovenia, e-mail: natasa.gajst@um.si. 
$1^{\text {ST }}$ InTERnATIONAL SCIENTIFIC CONFERENCE »TEACHING METHOdS FOR ECONOMICS AND BUSINESS SCIENCES«

\section{Table of Contents}

\section{CONFERENCE PROCEEDINGS}

The Importance of Relationships and Consistency in Bologna

Bob Johnson - Invited plenary lecture

A Review of Selected Measurement Tools of Transversal

Competences in Practical Training in Polish Higher Education

Beata Butryn, Anna Kuropka, Edyta Kulej-Dudek, Robert Kucęba \& Waldemar Jędrzejczyk

Creative Problem Solving Techniques in Undergraduate and

Postgraduate Economics and Business Studies

Vesna Čančer

Selected Methods of Practical Teaching in Polish Higher Education

Robert Kucęba, Waldemar Jędrzejczyk, Edyta Kulej-Dudek, Beata Butryn \& Anna Kuropka

Mindfulness: Does it Influence Students' Academic Success and

Personal Wellbeing?

Sonja Sibila Lebe \& Heri Špička

Contemporary Dilemmas in Teaching Economics and Business

Sciences

Franjo Mlinarič

Exam Wrappers: Reflecting on The Study Skills of Freshmen in MIS

Birgit Oberer \& Alptekin Erkollar

Participative Approach and Experiential Learning Approaches for the Students of Economics and Business Igor Perko \& Zoraida Mendiwelso Bendek

Simulations as a Teaching Method in Public Economics

Javier Sierra

Innovations in the Sustainable Accounting Teaching Methods in Hungary - Best Practices

Ágnes Siklósi \& Krisztina Sisa 
Using Business Simulation Methodologies in Higher Education:

Paulino Silva

Nonformal Activities for the Improvement of the Development of

Vocational Competences - the Polish Example

Maciej Szafrański, Marek Goliński, Ewa Wiecek-Janka, Magdalena

Graczyk-Kucharska \& Magorzata Spychała

Brainstorming Method for Developing Students' Transversal Skills

Tjaša Štrukelj

Selected Approach to Faculty's Ethical Decision-Making towards Building a Good Student Environment

Tjaša Štrukelj

Creative Learning through Simulated Firm

Amalia Venera Todoruţ

The Quest for Optimal Fusion of Learning, Teaching and Evaluation for Improving Student Classroom

Aneta Vasiljevic-Shikaleska, Martin Stojanovikj, Zanina Kirovska, Martin Kiselicki \& Biljana Gjozinska

Teaching Methods to Support Creative Environment 


\title{
The Importance of Relationships and Consistency in Bologna
}

\author{
BOB JOHNSON \\ ECBE COMMISSIONER FOR CREDIT RATING AND EX OFFICIO MEMBER OF THE BOARD OF \\ DIRECTORS
}

INVITED PLENARY LECTURE

\begin{abstract}
The basis of the Bologna process is a change in philosophy and pedagogy; a movement from 'inputs' to 'outcomes' which impacts upon the role and responsibilities of faculty, no longer just lecturers but a wider remit of being facilitators of student learning. The definition of level descriptors which overarch the whole process, lead to the definition of Intended Learning Outcomes (ILOs). Student performance is measured by the attainment of ILOs in relation to successful completion of assessment tasks. Assessment tasks and marking/grading schemes should be consistent with the level of demand of the ILOs and clearly identified as being diagnostic, formative or summative. A student's progress is measured in credits defined by a university or by state decree, where 1 credit is based upon ' $x$ ' Notional Learning Hours. Faculty need to recognise that NLT includes more than class contact hours (inputs) and that 'all relevant learning' should be considered.
\end{abstract}

Keywords: • level descriptors • intended learning outcomes (ILOs) • notional learning time $(\mathrm{NLT}) \bullet$ assessment $\bullet$ student performance $\bullet$

CORRESPONDENCE AdDRESS: Bob Johnson, Ph.D., Professor, European Council for Business Education, Rue J. Coosemans 30, B - 1030 Brussels, Belgium, e-mail: Bob.johnson66@ talktalk.net. 


\section{$1 \quad$ Introduction}

This paper examines the relationship and inter-connectivity between the fundamental building blocks of the Bologna process. It identifies the key words for the implementation and monitoring of the basic principles of Bologna and charts the sea-change from an 'inputs' dominated curriculum to an 'outcomes and achievement' philosophy. In addition, it gives guidelines for the successful use of the key indicators, an approach which is consistent with the Guidelines for European Standards (2015) as promulgated by ENQA and its members.

\section{Bologna - basic structure}

Bologna is underpinned by the measurement of the learning which takes place and the successful demonstration of its achievement. This has two facets, namely volume and level. The volume is measured by the number of ECTS credits - basic standard is 60 credits per full-time year of successful study. This could be two semesters, three terms or the equivalent for part-time and e-learning programmes.

\subsection{Number of credits}

The standard measure against which all credit-rating is based is 60 credits for a one year full-time programme of study which in theory should make it easy to work out the number of hours of learning per credit. Unfortunately this is not the case. Firstly, there is no standard agreement upon the number of hours a typical student spends learning per week. Is 40 hours per week reasonable?

Secondly, there are differences in the length of semesters; examples range from 12 weeks to 20 weeks! In most countries, the state or statutory body decides the number of hours per credit -a situation which has led to a range of learning hours per credit varying from $22 \mathrm{hrs}$ to $30 \mathrm{hrs}$. This is further confused by some working on clock hours and others on university hours (i.e. class hours of 55 minutes, 50 or even 45 minutes. In Russia, for example, 1 credit is based upon 36 (class) hours, usually equivalent to 27 clock hours).

\section{$2.2 \quad$ Level descriptors}

\subsubsection{Programme and qualification level descriptors}

There are three levels in the Bologna qualifications framework; bachelor, master and doctorate. Although this would appear to be a fairly standard approach, on its introduction the concept of a bachelor qualification was a major change for many countries that had a long history of five-year qualifications, e.g. the specialist programme in Russia. Some countries adopted a 3-year bachelor programme, but others a 4-year programme. Consequently, Bologna recognises both a 3 year, (180 credits) and a 4 year (240 credits) bachelor qualification. 
B.Johnson: The Importance of Relationships and Consistency in Bologna

Likewise, similar dilemmas arose at the master's level. Although in the majority of cases countries decided on a 2-year course (full-time or full time equivalent), there were others with extended 1-year masters' programmes. In addition, some masters are extensions of the bachelor studies, whilst others are 'conversion' masters where the main subject matter differs from that of the bachelors. As a consequence, the Bologna masters qualification is awarded to students with at least 90 credits; with a minimum of 60 credits at master's level where the subject remains the same.

Research doctorates are usually not credit-rated, apart although some universities may credit-rate specific aspects, such as research methodology. Taught doctorates, such as DBAs are credit-rated at 360 credits.

For each of these three cycles, there are programme level descriptors which identify the knowledge, skills and competences expected of students graduating from the three levels of qualifications.

\subsubsection{Stage/year (Credit) level descriptors}

Most qualifications are acquired over a period of three or four years of full-time study. It is unreasonable and not logical to expect the qualification (programme) level descriptors to apply to each year/stage of the programme. In order to identify the differences, it is necessary to define credit level descriptors to describe the knowledge, skills and competences achieved at the end of each stage or part of a stage, such as a module or course.

One way of distinguishing the differences between qualification/programmes level descriptors and stage/year/module/course credit level descriptors is that the former are a basis for determining the assurance of quality of the qualification and the latter are more generally used for programme development.

\subsubsection{Notional Learning Time (NLT)}

In devising a course or a module, it is necessary to bear in mind the time it will take a student to complete successfully the learning involved.A student's progress is measured in credits which are defined within a university or by national/state decree, as being 1 credit based upon ' $x$ ' Notional Learning Hours. Part of the learning time is easy to measure, notably class contact time, (CC); lectures, tutorials, seminars, in class assessment tasks etc. Whereas, other learning time such as preparation for the above activities, is directed study time, (DS) and relies on the time a student is expected (by the teacher) to spend on individual and group work preparing for lectures and other class activities. Furthermore, whilst junior students may not be expected to read 'outside'/'beyond the directed work, as they proceed through their programme, it is expected that there will be throughout the programme a consistently larger increase in the proportion of independent learning time (IS). 
In summary: $\underline{\mathrm{NLT}}=\mathrm{CC}+\mathrm{DR}+\mathrm{IS}+$ assessment time

Therefore, in designing the curriculum based on the number of credits, the faculty should bear in mind the expected learning hours and the proportion of time they expect the student to spend on each category.

In summary, in the planning and the monitoring stages, it is clear that there should be an overall coherence of the content matter (knowledge and skills) and progression in terms of increasing the demands of the course, its complexity, the depth of study and student autonomy (proportion of independent work).

There are a number of ways in which Credit Level Descriptors can be used e.g. Programme planning; internal and external quality assurance; but primarily, they are used to provide a framework of transparency for the design of intended learning outcomes/achievements. The intended learning outcomes for a course are there to give a clear and transparent view of the learning for both students and faculty.

\subsubsection{Intended Learning Outcomes}

The work developed by SEEC initially in 2002 with an update ' 3 rd education' in 2008 by D. Gosling and J. Moon, is still relevant and a valuable source for use by faculty. The principles they identified include the following

- All learning at whatever level can be expressed in terms of the outcomes to be demonstrated;

- Courses, modules, programmes are described in terms of their learning and assessment tasks and criteria;

- Learning outcomes should be as clear and unambiguous as possible;

- Learning outcomes identify the essential learning to be achieved to merit the award of credit.

An intended learning outcome is written within a framework of the relevant level descriptors and identifies what a student is expected to know, understand and/or be able to demonstrate at the end of a 'period' of learning. For any particular course, the ILO should be consistent with the framework of the programme learning outcomes and also the stage/year learning outcomes.

Hence ILOs are used in a number of situations, most notably

- at programme level, PLOs,

- at stage or year of programme level, and

- at course or module level, CLOs.

The number of intended learning outcomes is critical to the process of organising and delivering the learning. It is thought that between 5 and 8 intended learning outcomes are 
appropriate. They require the setting of appropriate assessment tasks and the defining of precise criteria. More than 8 leads to over-prescription, more appropriate to practical skill vocational courses; less than 5, usually leads to ILOs which are too general to be useful. Furthermore, they must be transparent and readily understood by both students and lecturers and hence should be written in clear everyday language.

A learning outcome should be clear and concise, leading to measurable achievements. An ILO usually starts with the phrase "At the end of this course students should be able to: "

ILO1 $\ldots . . . .$.

ILO2 $\ldots \ldots \ldots$

etc.

The learning outcome includes

- a verb that indicates what a learner should be able to do,

- words about the situation in which or on which the learner is working,

- words describing the nature of the performance required as evidence.

In turn, the course learning outcomes should assist the lecturer in designing the curriculum, in identifying the relevant elements of the NLT for their courses, together with the appropriate assessment tasks and criteria.

\section{$2.4 \quad$ Assessment tasks}

Assessment tasks are designed to allow the student to provide evidence that they have achieved the learning outcomes of the course. However, the purpose and role of each assessment task must be made clear to the students; is it diagnostic, formative or summative? Only the summative tasks are to be graded/marked and accumulated to give the overall grade/mark for the course.

Obviously therefore, they have to be consistent with the level determined by the ILOs. Many teachers find it useful to devise a matrix with the ILOs along one axis and the assessment tasks along the other.

Furthermore, it is important that the marking/grading is consistent with the level of learning described in the ILOs. This can be illustrated, for instance as follows in the example below.

\section{Example: Assessment task based upon a case study}

The same case study, asking the same question, the same assessment criteria, but with a different marking schemes (Table 1). 

AND BUSINESS SCIENCES«

B.Johnson: The Importance of Relationships and Consistency in Bologna

Table 1: Assessment criteria and marking schemes

\begin{tabular}{|l|l|l|}
\hline Marking criteria & Scheme A & Scheme B \\
\hline Description of problem & 50 & 5 \\
\hline Analysis of data & 30 & 55 \\
\hline Conclusions & 20 & 40 \\
\hline Total & 100 & 100 \\
\hline
\end{tabular}

Marking scheme A is designed for bachelor year 1 student, whilst scheme B is more appropriate for a year 3 student.

In short, generic Bologna qualification programme level descriptors are the over-arching framework within which

programme learning outcomes are defined and used as a framework under which are written the intended learning outcomes for each stagelyear of the programme.

The course/module learning outcomes are defined within the framework of stage/year ILOs, bearing in mind the programme ILOs.

Assessment tasks together with the appropriate assessment criteria are devised so that they provide the opportunity for students to produce the evidence to show that the course ILOs have been achieved.

\section{Conclusion}

None of these building bricks are easy to devise and will need constant monitoring, especially by those responsible for course ILOs, namely the teachers. They are the ones that keep a vigil on the continued relevance in a changing world. The teachers too will be monitoring the assessment tasks and grading criteria to ensure that they are consistent in content and level to that required to meet the Intended learning Outcomes, ILOs.

\section{References}

ENQA. 2015. Standards and guidelines for quality yssurance in the European higher education area (ESG). Brussels: Belgium. 


\title{
A Review of Selected Measurement Tools of Transversal Competences in Practical Training in Polish Higher Education
}

\author{
BeAta Butryn, AnNa Kuropka, Edyta KuleJ-DudeK, ROBERT KuCĘBA \& \\ WALDEMAR JĘDRZEJCZYK
}

\begin{abstract}
Competence measurement is related to the problems of assessing the growth of knowledge. Measuring the competence can estimate the level in each competence in relation to the expected requirements. Choosing the right measurement tools allows obtaining the information about which competencies expected by employers are the same alumni have. This article presents some of the tools for the measurement of transversal competences in the practical training of students. The authors have presented the characteristics of measurement tools for transversal competences, and indicated measurement standards for transversal competences. The paper includes the analysis of how selected tools are used for exploring transversal competences.
\end{abstract}

Keywords: - competences - transversal competences • competences measurement $\bullet$ practical training $\bullet$ higher education $\bullet$

CorRespondence AdDresses: Beata Butryn, Ph.D., Assistant Professor, Wrocław University of Economics, Ul. Komandorska 118-120, 53-345 Wrocław, Poland, e-mail: beata.butryn@ue.wroc.pl. Anna Kuropka, M.Sc., Ph.D. student, Wrocław University of Economics, Ul. Komandorska 118-120, 53-345 Wrocław, Poland, e-mail: anna.kuropka@ue.wroc.pl. Robert Kucęba, Ph.D., Czestochowa University of Technology, Armii Krajowej 19B Avenue, 42-201 Częstochowa, Poland, e-mail: robertkuceba@wp.pl. Waldemar Jędrzejczyk, Ph.D. Associate Professor, Czestochowa University of Technology, Armii Krajowej 19B Avenue, 42-201 Częstochowa, Poland,e-mail: waldekj@zim.pcz.pl. Edyta Kulej-Dudek, Ph.D., Assistant Professor, Czestochowa University of Technology, Armii Krajowej 19B Avenue, 42-201 Częstochowa, Poland, e-mail: edku@ zim.pcz.pl. 


\section{Introduction}

Competences are knowledge, the ability to work and the basis for the whole, depending on the objectives and operating conditions (Thiery, Sauret, \& Monod, 1994, p. 6). The role of competences in the time of increasing globalization and technological progress is constantly growing. Human capital is an essential element of economic growth of any country. Rapid changes in the labor market and the changing demand for certain skills necessitate continuous training (life-long learning) and the development of the skills related to their work or future. According to the report by Eurydice (www.eurydice.gov.pl) 'Developing Key Competences at School in Europe: Challenges and Opportunities for Policy' in schools, too little attention is placed on transversal competences (technical, entrepreneurial). Therefore, it is very difficult to evaluate them, because testing and external examinations focus on the analysis of basic skills. At the same time, the report points to the existence of a large need for the support for the development of transversal competences; as compared with basic skills, these competences are rarely taught. Ultimately, this will require from schools a change of the whole curriculum, and thus formalizing some of the transversal competences, considered learning outcomes and assessment methods. It is important to note that labor market is the main verifier of student's competences. Acquired competences during the academic education process are one of the main determinants of a career. Over the last years, the discussion about the role of universities in Polish economy has been a continuous one. It has been identified that there is a need for education which is designed to match the needs of employers due to the changing situation on global labor market and the growing demand for highly-skilled workforce. The creation of the curriculum which will correspond to the current needs of the market is one of the main challenges currently faced by every university in the world. There is a strong need to create an offer that will allow the student to acquire such competencies which are in demand by employers. Trying to correspond with the expectations of employers and knowing the dynamics and variability of individual sectors of the economy, the main objective in the design of the curriculum should be training people who will have those skills to enable them to smooth the transition to the labor market and continue a career on both the local and international markets. This goal determines further tasks associated with the selection of methods and tools for measuring transversal competences. In the case of verifying the transversal competences acquired in the process of teaching in Polish higher education, a challenge associated with reliable, correct and consistent selection of appropriate methods and tools exists.

\section{$2 \quad$ Methods and tools of transversal skills measurement}

The measurement of competence allows for the evaluation of the level of mastery of transversal competences in relation to the formulated requirements. Its purpose is the analysis and opinion about real competence, which will result in obtaining information for determining whether the competencies expected by employers are the real powers held by the graduates. 
B. Butryn, A. Kuropka, E. Kulej-Dudek, R. Kucęba \& W. Jędrzejczyk: A Review of Selected Measurement Tools of Transversal Competences in Practical Training in Polish

Higher Education

The concept of diagnosis, prognosis and assessment is closely related to the measurement of a competence. Diagnosis means recognizing states of affairs on the basis of their symptoms (Jurek, 2013). The forecast is determined by the prediction of what will be observed before it occurs in reality. The rating is defined as the measurement with use of estimates so that only the public, objectively observed behavior is assessed (Reber, 2000). This includes a record of the appearance or absence of the behavior and valuation and/or estimating the intensity and frequency of behavior (Pocztowski \& Miś, 2000). The premise of measurement is to look for certain types of competencies and their level of fulfilment among the respondents. In the literature, there is no uniform position regarding the methods of measuring competence. During the process of methods selection, the methods which are normally taken into consideration are those that are (Jurek, 2010):

- generally recognized and used in the practice of human resource management,

- methodologically and psychometric diversified,

- popular.

Taking into consideration the above criteria, it is possible to identify three groups of tools that can be used to measure the development of transversal competences:

- tests,

- interviews,

- multi-source,

- Assessment \& Development Center.

There are new trends emerging in competence testing, and they primarily include (Jurek, 2013):

- complex cognitive exercises used during an Assessment Center session,

- computer games, which allow the diagnosing of competences (Jurek \& Marcinkiewicz, 2014).

Tests are one of the most popular methods to diagnose competences (WieczorekSzymańska, 2012, pp. 105-108).Testing professional knowledge is commonly used to evaluate the competence of job candidates, but is rarely used to analyze the competence of students. However, the implementation of this tool in the evaluation of the growth of transversal competences among students can be a modern solution in the process of teaching. More extensive tools are competency tests (Emmons, Diener, \& Larsen, 1986), which are designed to identify patterns of behavior of respondents arising from their knowledge and experience acquired. In practice, competency tests are often an alternative to situation testing. This is due to comparatively high costs of preparing and carrying out situational judgment tests, which require procedures to reconstruct situations which may occur in reality (Smółka, 2008, p. 82). Psychometric tests provide standardized and 
objectified methods used for determining the possessed or only expected psychological traits in subjects. The research tools of this type need to be prepared and carried out, and the results interpreted by a person with specialized competences - a psychologist (Wieczorek-Szymańska, 2012, pp. 105-108). It should be highlighted that the most reliable results are obtained with a combination of different tools of specific method verification and research. Tests are simple and fast to use, allow easy analysis of the results as reliable, and enable simultaneous testing of a large number of people. The disadvantage of this method is to obtain quantitative results, which do not allow the correct inference quality (ibid.). Situational judgment tests (task tests), also known as simulations, allow us to obtain the most quality results. Here, the essence is to assess the level of selected competences on the basis of observing a subject's behavior in a situation that simulates a challenge characteristic for the professional role or position or - in the case of students - the tested transversal skills. Tests of this type are the basis for integrated assessment (Assessment \& Development Center). Situational judgment tests have a significantly higher cost of preparation and application.

Interviews can be a good tool to supplement information obtained through a selected test method. In the process of evaluating growth of transversal skills, interviews may take the form of biographical (focused on a subject's social and professional experience), behavioral (focused on typical behaviors of the evaluated person in specific social and professional situations) or situational interviews (involving hypothetical determination of a subject's future behavior) (Dipboye, Wooten, \& Halverson, 2004, pp. 273-316).

Participation in the interview helps to obtain much more information about a respondent. It is important to note that the material gathered during the interview contains only subjective statements of respondents; therefore, it should not be used as the only tool for reliable assessment of practical skills.

Competencies assessment in addition to the tests and interviews can be made by collecting comments about the student from the people who interact with it. The idea of such an assessment of competence is to provide the assessed person multifaceted feedback on the perception of the behavior of other regressed persons (using feedback). It should be noted that in the case of the 360 degrees feedback, the researchers may use different variants of it, 180 degrees, 270 degrees or 540 degrees feedback. The 180 degrees method utilizes two in the $270^{\circ}$ three sources of information on the skills, the $540^{\circ}$ all those who had the opportunity to work together with the audited student (McCarthy \& Garavan, 2001, pp. 11-12).

A fundamental feature distinguishing $360^{\circ}$ feedback from the traditional method of evaluating employees or students lies in the multi-source of opinions, which allows a comparison of an employee's self-evaluation with the evaluation by others. This method requires appropriate training of participants, which is associated with specific costs, while increasing the number of assessors may prolong the process. Other limitations of the 
B. Butryn, A. Kuropka, E. Kulej-Dudek, R. Kucęba \& W. Jędrzejczyk: A Review of Selected Measurement Tools of Transversal Competences in Practical Training in Polish

Higher Education

method relate to, among others, an incorrectly constructed evaluation questionnaire, and a sense of danger in:

- assessed, subjective selection of evaluators,

- assessment of the difficulties of transversal competences (Garavan Morley, \& Flynn, 1997, pp. 144-145).

Methods that provide highly reliable results of competence evaluation are Assessment Center (AC) and Development Center (DC) (Zachariasz-Łobodzińska, 2009, p. 55). These are multi-factorial, most advanced methods to evaluate competence potential. They consist of the preparation and conduct of meetings during which students perform a series of exercises (e.g. discussion, case study, role play, etc.) constructed in such a way that the subjects are able to demonstrate specific competencies. Assessment of the level of competence development is performed by assessors using appropriately designed tools, for example, scales estimates. Process A\& DC may be affected by several factors. Critical areas may relate primarily to improper preparation of assessors, improper selection of techniques and exercises during the session, and incorrectly prepared feedback. They are also characterized as time-consuming and costly (Parteka, 2003, p. 29). Despite the potential 'problems' with carrying out of A \&DC, these methods have advantages. Feedback, which the test person receives, is usually clear and constructive, and using a variety of techniques and the complicity of many assessors can provide a relatively high level of objectivity and versatile evaluation.

\section{Standards of transversal skills measurement}

Most theorists believe that competence measurement is a complex process, which can be carried out in an objective manner based on specific behaviors. The complexity and the difficulty of assessing the measurements arise from the volatility of competence over time. Even at relatively short intervals, changes in the level of development of a given competence, acquired through education and experience, can be observed. In order to ensure a reliable measurement, that is, a measurement which actually reflects the level of competence shown, the adopted standards should be respected. In determining standards for the measurement normally is accounted:

- the effect of the beholder (evaluator),

- the effect of the object (assessed person),

- the effect of relationships, the effect of the methods (procedures, tools). 
$1^{\text {ST }}$ INTERNATIONAL SCIENTIFIC CONFERENCE $\gg$ TEACHING METHOdS FOR ECONOMICS AND BUSINESS SCIENCES«

B. Butryn, A. Kuropka, E. Kulej-Dudek, R. Kucęba \& W. Jędrzejczyk: A Review of Selected Measurement Tools of Transversal Competences in Practical Training in Polish Higher Education

Planning to observe behavior in the transversal competences assessment should keep in mind several conditions, such as (Pocztowski, \& Miś, 2000):

- any behavior is located in a situational context,

- any behavior or sequence of behavior has its cause and consequences for future behavior,

- any behavior subjected to observation should not be analyzed without considering the role of the individual to whom certain behavior is expected.

Filipowicz distinguishes 5 basic methods of competence measurement, such as (Filipowicz, 2002, pp. 25-26):

- observation scale describing a person's behavior at a given competence level,

- competence tests, used for initial self-diagnosis and introducing participants to the issues related to competence measurement-introspective tests, as well as those focusing on the ability to select effective behavior in given, specifically defined situations - performance tests,

- participant observation with the use of the information collected during observation of the evaluated person when performing tasks,

- self-tests carried out using standard, universal questionnaires or interviews (group, individual, expert panels),

- development center requiring considerable expenditure of resources and time of the person assessed and involvement of auditors.

Scales are used for competence measurement. Such scales can be used to describe competence levels. Usually, these are (Czyżyński, Łęgocki, \& Werewka, 2012):

- nominal scales,

- ordinal scales,

- interval scales together with ordering the levels,

- quotient scales.

The most common description of the competence of the cross-cutting is done on a 5-level, anchored rating scale in which the first level is the lowest possible degree of ownership of competence (can also mean lack thereof), and the fifth level is the highest degree (Filipowicz, 2007, p. 26):

- level 1 (low) - lack of acquiring a particular competence; the subject does not manifest behavior indicative of possessing such a competence in a situation, which requires it;

- level 2 (basic) - the competence acquired at a basic level; the subject attempts to behave as expected, to deal with tasks that require a particular competence; 
B. Butryn, A. Kuropka, E. Kulej-Dudek, R. Kucęba \& W. Jędrzejczyk: A Review of Selected Measurement Tools of Transversal Competences in Practical Training in Polish

Higher Education

- level 3 (good) - competence acquired at a good level; the subject is able to use a particular competence when carrying out specific tasks;

- level 4 (advanced) - competence acquired at a very good level, allowing for very good performance of tasks in a given field;

- level 5 (outstanding) - competence acquired at an excellent level, the subject creates model solutions and good practices.

Another category of descriptive scale is a scale which shows the behavior patterns corresponding to different levels of assimilation that competency. It is created based on the identification of several specific categories of behaviors for each competency, and then determines the expected behavior for different levels of competences. This description of competence is applicable in cases where the level of control competence of the examined person is inconsistent (some of the indicators reach a high level, other lower) (Staniszewska, 2014).

Regardless of the methods or tools chosen to measure transversal competence, it is important to meet each of the requirements (ibid.):

- accuracy,

- reliability,

- normalization.

In the transversal competences case, a major problem for the assurance of the accuracy, reliability, and normalization is to ensure consistency regarding the competence and determination nature of the criteria, whether the powers are examined on the basis of direct behaviors, or indirectly, have the status of abstract qualities. Many difficulties are also competency creating models that are 'tailor-made', which is not accompanied by comprehensive theoretical background and the stages of empirical confirmation defined criteria; therefore, the assessment of the competence may be taken into account is behaviors that do not have to coexist.

\section{The application of methods and measurement tools among Polish students}

Because of market requirements and the increasing competition between academic centers, higher education institutions are obliged to use systematic actions to measure and evaluate learning outcomes and finally their maximization. For the measurement of competence, surveys and tests are used primarily.

A questionnaire survey is a measurement tool which can be used in a traditional way or via the web. It is currently the most popular method of testing due to the flexibility in choosing how to carry it out, and the nature of questions asked (questions can be open or closed). Most of the problems during the testing of the students are related to the same weaknesses as surveys measuring tools: poor formulation of questions (suggesting 
B. Butryn, A. Kuropka, E. Kulej-Dudek, R. Kucęba \& W. Jędrzejczyk: A Review of Selected Measurement Tools of Transversal Competences in Practical Training in Polish Higher Education

questions, too complex questions, etc.), inappropriate choice of scale. A well-designed questionnaire allows the capturing of the competence of the individual student and also the entire population of students. At the same time, it should be a source of information for lecturers and university authorities. Obtaining a critical evaluation should not be perceived negatively. It should be an indication, motivation and incentive to change ways of teaching and focus on obtaining a student specific competence. The survey and its results allow universities to adapt to the dynamic market environment, and properly carried out and used, it allows educational services to be provided at the possible highest level.

When in Poland, in the framework of the project 'Human Resources for the Economy', periodic checks are carried out under the title 'The degree of adjustment of students' skills to the needs of future employers', the analysis is subjected to the competence of students, that is, knowledge, experience and attitudes (personality traits). They have been developed based on the research literature and research in the scientific community. In the questionnaire, respondents are asked to assess the competence identified. It includes two perspectives:

- state of possession,

- opinion on the usefulness in terms of the view of the labor market.

In order not to suggest answers to questions asked during the survey, the respondents are not disclosed competence groups, nor their names. Also, the respondents answer the questions: 'Do you agree with the statement?' and 'Is the given ability, in your opinion, useful on the labor market?'. Possible answers and scales are:

1 - definitely yes,

2 - rather yes,

3 - neither yes nor no,

4 - probably not,

5 - definitely not.

Students also answer additional questions:

- their current status,

- faculty, course of study and specialization,

- academic performance,

- additional parallel studies in other fields,

- experience gained during studies,

- gender,

- year of birth,

- place of residence,

- their parent's education level. 
B. Butryn, A. Kuropka, E. Kulej-Dudek, R. Kucęba \& W. Jędrzejczyk: A Review of Selected Measurement Tools of Transversal Competences in Practical Training in Polish Higher Education

Open-ended questions allow for the expression of an opinion on the level of preparation of students for professional work and the motives for study. Only the collection and comparison of the opinions of those three groups allows for a full assessment of the competence of the students. The questionnaire was prepared in three different versions.

The second most popular method for testing a competence is the participation in the tests, which allows for the identification of the strengths and weaknesses of the student and the organization. An example of a standardized test of competence used in Poland includes 4 test auxiliaries which facilitate diagnosis competence in the field of social competence, organizational, personal and cognitive.

\section{Description of the structure of the test}

30 questions concerning practical knowledge necessary for the proper functioning of the group: networking and building relationships with others, providing information and persuading others about their own position.

Tested competences:

1. Interoperability - to establish working groups to achieve common goals.

2. Communication skills - ensuring the exchange of information between other persons.

3. Influence -- convincing others to their own position and the incitement to the proposed course of action.

* 30 questions concerning practical knowledge necessary to cope with difficulties and changing working conditions.

Tested competences:

1. Adapting to change - easy to adapt to changing situations.

2. Focusing on the task-focusing on actions needed to achieve the expected results.

3. Coping with stress - functioning in situations accompanied by load/emotional tension.

* 30 questions concerning practical knowledge necessary for the efficient implementation of tasks in accordance with the assumptions.

Tested competences:

1. Planning - determining the course of action with regard to the stages and the necessary measures.

2. Organize - to implement activities in accordance with the prescribed plan.

3. Control-control the compliance of the prescribed plan. 
$1^{\text {ST }}$ INTERNATIONAL SCIENTIFIC CONFERENCE $\gg$ TEACHING METHOdS FOR ECONOMICS AND BUSINESS SCIENCES«

B. Butryn, A. Kuropka, E. Kulej-Dudek, R. Kucęba \& W. Jędrzejczyk: A Review of Selected Measurement Tools of Transversal Competences in Practical Training in Polish Higher Education

* 30 questions concerning practical knowledge necessary to cope with the analysis of problematic situations, making inferences and creative problem solving.

Tested competences:

1. Analytical thinking - a detailed analysis of the situation and its components.

2. Thinking conceptual - the creation of general concepts and strategies.

3. Innovation - seeking and accepting new ways of tasks (www. Jobfitter.pl).

For comparison, a characteristic example of the method of testing the competence of the students and to measure the results of educational programs is the Collegiate Learning Assessment (CLA), launched in 2000 by the Council for Aid to Education (CAE) in New York. It requires students to use their cognitive skills to efficiently construct a reply in relation to real problems. Test modules include: reading, teaching critical thinking, math, writing skills and essay writing.

The purposes of CLA are: it uses direct measures of student learning rather than proxies for it; typical proxies include input or actuarial data (e.g., entrance examination scores or faculty salaries), student self-assessments of growth, or college faculty and administrator opinion surveys:

- the CLA project focuses not on discipline-specific content but, instead, on general education skills--critical thinking, analytic reasoning, and written communication. The measures are all open-ended rather than multiple-choice,

- the project uses a "matrix-sampling" approach to assessment. The traditional approach, which would be to administer an entire battery of instruments to all students, would be too time-consuming to be practical.

- the project was designed to assess value added, or the institutional contribution to student learning (http://www.aacu.org/publicationsresearch/periodicals/new-field-dreams-collegiate-learning-assessmentproject).

Schools participate in the CLA to gauge not only the range of academic abilities in their students and the extent to which these abilities are different from one group of students to the next, but also to see if these differences match up with their expectations and their efforts to improve and deliver quality programs (https://www.york.cuny.edu/studentdevelopment/college-learning-assessment/college-learning-assessment).

The diversification of the types and content of surveys and tests allows for the proper fit into different areas of specialization. Elements which have a substantial impact on the choice of research method are primarily the costs and the time required to carry out the 
B. Butryn, A. Kuropka, E. Kulej-Dudek, R. Kucęba \& W. Jędrzejczyk: A Review of Selected Measurement Tools of Transversal Competences in Practical Training in Polish Higher Education

research. Planning research ensures adequate sample size research, which makes students aware of the benefits of participation in them.

\section{Conclusions}

Based on a review of selected methods and tools for measuring transversal competences, it can be assumed that many methods and tools can be used to measure transversal competences in higher education, although in the case of test psychometrics parameters defining a given jurisdiction are normally declarative in nature. In contrast, Assessment $\&$ Development Center and the method of multi-source $360^{\circ}$ and $180^{\circ}$, allow for relatively satisfactory reliability of forecasts transversal competences in the process of practical students teaching.

Experience in Polish higher education shows that for testing transversal competences, surveys / questionnaires and tests are usually used. Analyzing tests leads to the conclusion that the inference about the level of transversal competences can accurately predict the expected behavior, but there is no assurance that specific competencies are tested. The presented method has a number of methodological limitations, mostly related to the creation of consistent competency models. It is advisable to apply for the level of competence based on the basis of more than one study and using more than one method.

\section{References}

Aranowska E. (2005). Pomiar ilościowy w psychologii. Warszawa: Scholar.

Czyżyński Ł., Łęgocki M., \& Werewka J. (2012). Zarządzanie kompetencjami kierowników projektów zgodnie ze standardami PMBOK $i$ definicja PMCDF, CSL R\&D Report 3/0/2009. Kraków: AGH.

Dipboye R. L., Wooten K., \& Halverson S.K. (2004). Behavioral and situational interviews. In J. C. Thomas (Ed.), Comprehensive handbook of psychological assessment (pp. 297 - 316). Hoboken, NJ: John Wiley \& Sons Inc.

Emmons R. A., Diener E., \& Larsen R.J. (1986). Choice and avoidance of everyday situations and affect congruence: two models of reciprocal interactionism. Journal of Personality and Social Psychology, 51 815-826.

Filipowicz, G. (2000). Pracownik wyskalowany czyli metody i narzędzia pomiaru kompetencji. Personel, 1(7). Warszawa.

Filipowicz., G. \& Sterczyński, R. (2002). Testy kompetencyjne - metody i narzędzi pomiaru kompetencji. Personel, 16(30), Warszawa.

Garavan, T. N., Morley, M., \& Flynn, M. (1997). 360 degree feedback: its role in employee development. Journal of Management Development, 16(2), 134-147.

Jurek, P. (2010). Rzetelność i trafność pomiaru kompetencji transferowalnych z wykorzystaniem wybranych narzędzi i metod. In S. Konarski, \& D. Turek (Eds.), Kompetencje transferowalne. Diagnoza. Ksztaltowanie Zarzadzanie (113-135). Warszawa: Oficyna Wydawnicza SGH. 
$1^{\text {ST }}$ INTERNATIONAL SCIENTIFIC CONFERENCE $\gg$ TEACHING METHOdS FOR ECONOMICS AND BUSINESS SCIENCES«

B. Butryn, A. Kuropka, E. Kulej-Dudek, R. Kucęba \& W. Jędrzejczyk: A Review of Selected Measurement Tools of Transversal Competences in Practical Training in Polish Higher Education

Jurek P. (2013). Definiowanie i pomiar kompetencji zawodowych. Seminarium pt. Droga do kariery- zawód czy kompetencje, Słupsk 16 października 2013. [PowerPoint slides]. Retrieved from: wup.gdansk.pl/g2/2013_10/f81833841991cc4689c36bb1faef1a92.ppt.

Jurek P., \& Marcinkiewicz, A. (2014, May 27). Gry komputerowe - przyszłość w diagnozie i rozwoju kompetencji zawodowych. GazetaPraca. Retrieved from http://gazetapraca.pl/gazetapraca/1,131108,16043411,Gry_komputerowe przyszlosc_w _diagnozie_i_rozwoju.html.

McCarthy A. M., \& Garavan T. N. (2001). $360^{\circ}$ feedback process: Performance improvement and employee career development. Journal of European Industrial Training, 25(1), 5-32.

Parteka A. (2003) Ocena kompetencji kluczowych dla firmy. Manager, 9, 26- 29.

Pocztowski A., \& Miś A. (2000). Analiza zasobów ludzkich w organizacji. Kraków: Wydaw, Akademii Ekonomicznej.

Reber, A. S. (2000). Stownik psychologii. Warszawa: Scholar.

Smółka P. (2008). Kompetencje społeczne. Metody pomiaru i doskonalenia umiejętności interpersonalnych. Kraków: Oficyna Wolters Kluwer Business.

Staniszewska A. (2014). Model kompetencji i kwalifikacji specjalistów do spraw zamówień publicznych $w$ administracji. Poznań: Politechnika Poznańska 2014. Retrieved from

http://repozytorium.put.poznan.pl/Content/315677/Anna_Beata_Staniszewska_Model_kompetenc ji_i_kwalifikacji_specjalistow_do_spraw_za

mowien_publicznych_w_administracji.pdf

Thiery D., Sauret Ch., \& Monod N. (1994). Zatrudnienie i kompetencje w przedsiębiorstwach w procesach zmian. Warszawa: Poltext.

Wieczorek-Szymańska, A. (2012). Metody pomiaru kompetencji pracowników worganizacji. Makro- I Mikroekonomiczne zagadnienia gospodarowania, finansowania, zarzadzania; Studia i Prace Wydzialu Nauk Ekonomicznych i Zarzadzania, 30, 105-115.

Zachariasz-Łobodzińska A. (2009). Badanie kompetencji. Proces doboru i oceny pracowników (3). Personel i Zarządzanie, 1, 56-59. 


\title{
Creative Problem Solving Techniques in Undergraduate and Postgraduate Economic and Business Studies
}

\author{
VESNA ČANČER
}

\begin{abstract}
This paper seeks to compare the need and the possibility of teaching Creative Problem Solving Techniques to undergraduate and graduate students in economic and business sciences. It aims to select arrays of techniques appropriate for and delineates the performance of the course at the undergraduate and postgraduate studies. It suggests graduate students the use of Problem Structuring Methods to deal with wicked problems or messes, and to raise their experience in the use of multimethodology. Reflections on the teaching of the topic draw the following conclusion. Since graduate students have an in-depth and systematic understanding of knowledge in their specialized study fields and across them, and because they usually have more work experience than their undergraduate colleagues, they can use creative problem solving techniques to solve specialized real-life problems, e.g. the ones that require a problem definition in multi-criteria decision making, and implement the results in practice.
\end{abstract}

Keywords: • creative problem solving • economic and business sciences - education • postgraduate studies $\bullet$ undergraduate studies $\bullet$

CORRESPONDENCE AdDRESS: Vesna Čančer, Ph.D., Associate Professor, University of Maribor, Faculty of Economics and Business, Razlagova ulica 14, 2000 Maribor, Slovenia, e-mail: vesna.cancer@um.si. 


$1^{\text {ST }}$ INTERNATIONAL SCIENTIFIC CONFERENCE »TEACHING METHODS FOR ECONOMICS
AND BuSINESS SCIENCES«
V. Čančer: Creative Problem Solving Techniques in Undergraduate and Postgraduate
Economic and Business Studies

\section{Introduction}

The courses on creative problem solving techniques suggest teaching current and potential problem solvers in economy and business: to define problems/opportunities/solutions, to generate and choose creative and useful ideas/opportunities/solutions, and to verify them. The intended learning outcomes are meant for problem solvers who are trying to solve a problem in a creative way (Vidal, 2010). Besides problem solvers, enterprises are generally interested in people who adopt creativity as a life-style, and are creative not only at work, but also at home and everywhere. We have already expressed our opinion that artistic persons are relevant especially for service enterprises that deal with advertising, cultural events etc. (Čančer, 2014).

Teachers and practitioners in several fields agree that problem solvers need the skills to enable them to face with complexity, among them the creative problem solving (CPS) skills (McWilliam \& Haukka, 2008; Wood \& Bilsborow, 2014). In the economy and business filed, too, it has already been recognized that decision makers require unconventional thinking to solve problems with limited information and resources, emphasizing the CPS skills (Butler, 2010). Although the literature review enables us to draw the conclusion that particularly on the undergraduate level, there are courses on CPS (Im, Hokanson \& Johnson, 2015; Wood \& Bilsborow, 2014), the belief that universities are "failing to equip graduates with the creative skills they require to be effective in the workplace" is strongly present (Wood \& Bilsborow, 2014, p. 111).

The paper aims to select arrays of techniques appropriate for undergraduate and postgraduate studies. It delineates the performance of the course at the postgraduate study and compares it with the one at the undergraduate study. Exploratory and descriptive research is employed to select arrays of creative problem solving techniques appropriate for undergraduate and graduate students in economic and business studies, and to compare the need and possibility of teaching these methods to them.

The organization of the paper is as follows: The second section introduces and compares the proposals of the syllabus outlines of the creative problem solving techniques suitable for the undergraduate and graduate studies. The third section specifies the courses on creative problem solving techniques at the undergraduate and postgraduate level, respectively. It delineates the performance and type of the courses, duration, learning and teaching methods. In the last section, we draw conclusions about the abilities of problem solvers obtained with the considered course, and give some suggestions for implication for teaching practice.

\section{Possible content of the courses on creative problem solving}

Creative Problem Solving is the framework process of solving problems, which includes the techniques of creative and critical (e.g. decision) thinking with the aim of designing and developing new and useful outcomes (Isaksen, Dorval \& Trefinger, 1994). According 
V. Čančer: Creative Problem Solving Techniques in Undergraduate and Postgraduate Economic and Business Studies

to Wood and Bilsborow (2014), the CPS framework needs to be adapted to suit the field of the study. To meet the intended learning outcomes for current and potential problem solvers in the economic and business field, the syllabus outline can include the phases of the CPS process (Cook, 1998): problem definition, generating ideas, choosing ideas, and solution implementation. When structuring the content of the course with respect to these phases, special attention can be given to:

- the tools and approaches for a mess, fact and problem/opportunity finding and definition, based on questions and visualization, together with Problem Structuring Methods (PSM);

- the creative thinking tools and approaches (verbal and written) for the generating, decomposing and analyzing of ideas/opportunities/solutions;

- the creative and Operations Research (OR) methods for their evaluation, selection and verification - among them we emphasize the multi-criteria decision-making (MCDM) ones;

- the tools and approaches for solution implementation.

Based on the above written CPS process, the content of the course on the creative problem solving techniques suitable in undergraduate studies can include:

- Methods for problem and opportunity definition:

- Introduction: types and characteristics of problems, problem definition, problem solving phases;

- Techniques;

- Computer support;

- Applications on practical cases with appropriate computer support;

- Methods for idea generation:

- Introduction: types of thinking, meaning, role and characteristics of creative thinking, conditions for creative thinking, blocks to creativity;

- Techniques;

- Computer support;

- Applications on practical cases with appropriate computer support;

- Decision-making methods supportive of creative problem solving:

- Introduction: decision-making support, role and overview of quantitative methods for problem solving, traditional and alternative approaches for the evaluation, selection and verification of ideas/opportunities/solutions, frame procedure of solving multi-criteria decision-making; 
V. Čančer: Creative Problem Solving Techniques in Undergraduate and Postgraduate Economic and Business Studies

- Quantitative methods supportive of decision-making (evaluation, selection and verification of ideas/opportunities/solutions) in creative problem solving considering multiple criteria;

- Computer support for decision-making;

- Applications on practical cases of evaluation, selection and verification of ideas/opportunities/solutions, with appropriate computer support.

Selected traditional and modern methods for strengthening creativity have already been included into several courses that are offered at undergraduate and postgraduate economic and business programs; however, these courses are usually limited only to some selected study fields. To overcome this deficiency, it is suggested that an elective course on creative problem solving is developed and offered to students of all study fields at the undergraduate level.

We also introduce possible content of the course on creative problem solving that is a part of the module on Quantitative Methods in Business Science at the postgraduate level:

- $\quad$ Problem structuring methods

- Methods for problem definition;

- Cognitive mapping, strategic options development and analysis;

- Strategic choice approach;

- Problem structuring with factor analysis;

- Multi-criteria decision-making methods

- An overview of multi-criteria methods;

- Multi-criteria value measurement;

- The determination of criteria's importance, interactions among criteria's importance (additive model, types of interactions, multiplicative model, Choquet integral);

- The analytic hierarchy process;

- Group decision-making;

- The analytic network process (networks, dependence and feedback);

- Preference programming;

- Solution implementation

- Selective deepening

- Applications of the considered methods and approaches in economic and business practice. 
V. Čančer: Creative Problem Solving Techniques in Undergraduate and Postgraduate Economic and Business Studies

Based on the proposed syllabus outlines, we selected arrays of creative problem solving techniques appropriate in undergraduate and postgraduate studies and introduced them in Table 1.

The syllabus outline for undergraduate students includes a wide-ranging array of techniques for problem definition, based on questions and visualization; idea generation, the written and the verbal ones; and idea selection, where special attention is given to the computer supported methods based on one of the most widely applied sets of multicriteria methods - multi-attribute value (or utility) theory (MAVT or MAUT), e.g. SMART and the Analytic Hierarchy Process (AHP) method (see, e.g. Belton \& Stewart, 2010; Saaty, 2005) (Table 1). At the postgraduate studies, however, the techniques for problem definition $^{1}$ that are taught at the undergraduate studies should be requisitely dealt with following the students' knowledge base and eventually expressed intentions for selective deepening. Greater attention is given to Soft OR or PSM in order to prepare the foundation for further problem solving based on the quantitative decision-making methods.

Table 1: Selected arrays of creative problem solving techniques in undergraduate and postgraduate studies

\begin{tabular}{|c|c|}
\hline $\begin{array}{c}\text { Selected techniques in undergraduate } \\
\text { studies }\end{array}$ & Selected techniques in postgraduate studies \\
\hline $\begin{array}{l}\text { METHODS FOR PROBLEM AND } \\
\text { OPPORTUNITY DEFINITION } \\
\text { W, 5Ws \& H, why, the five whys; } \\
\text { Mind mapping; fishbone diagrams, outcome } \\
\text { checklists; } \\
\text { CREATIVE THINKING METHODS } \\
\text { Brainstorming, brain-writing, ideas writing, } \\
\text { nominal technique, forced relationships, } \\
\text { attribute listing, morphological analysis; } \\
\text { DECISION-MAKING METHODS } \\
\text { SUPPORTIVE OF CREATIVE PROBLEM } \\
\text { SOLVING } \\
\text { Simplified Multi-attribute Rating Technique } \\
\text { - SMART, The Analytic Hierarchy Process - } \\
\text { AHP; }\end{array}$ & $\begin{array}{l}\text { PROBLEM STRUCTURING METHODS } \\
\text { Methods for problem definition: W, 5Ws \& H, } \\
\text { why, the five whys; } \\
\text { Cognitive Mapping, Strategic Options } \\
\text { Development and Analysis - SODA; } \\
\text { Strategic Choice Approach - SCA; } \\
\text { Problem structuring with factor analysis - } \\
\text { Principal Component Analysis and } \\
\text { Exploratory Factor Analysis; } \\
\text { MULTI-CRITERIA DECISION-MAKING } \\
\text { METHODS } \\
\text { The Analytic Hierarchy Process - AHP, The } \\
\text { Analytic Network Process - ANP; } \\
\text { Preference Programming (Preference } \\
\text { Assessment by Imprecise Ratio Statements - } \\
\text { PAIRS, Simple PAIRS; Rank Inclusion in } \\
\text { Criteria Hierarchies - RICH, Preference } \\
\text { Ratios in Multi-attribute Evaluation - } \\
\text { PRIME); } \\
\text { Modeling risk and uncertainty (decision trees } \\
\text { and influence diagrams); } \\
\text { SOLUTION IMPLEMENTATION METHODS } \\
\text { Balance sheets, implementation checklists, } \\
\text { critical path analysis; }\end{array}$ \\
\hline
\end{tabular}


According to our own practical experience and findings of other researchers (see, e.g., Harlim \& Belski, 2013), problem identification and definition is the most crucial stage in problem solving. The paper suggests graduate students the use of methodologies, known as Problem Structuring Methods to deal with wicked problems or messes, and to raise their experience in the use of multi-methodology. In everyday economic and business practices, many problems are ill-defined and consequently poorly structured. They are open and broad. Over the last fifty years, new methods and methodologies that are collectively known as Soft OR, Soft Systems, or PSM have been developed to deal with wicked problems (Churchman, 1967) or messes (Mingers, 2011), among them:

- Soft Systems Methodology (SSM)developed by Checkland (1981; 2001) for messy, changing, ill-defined problems;

- Strategic Options Development and Analysis (SODA)(Eden \& Ackerman, 2001) for problems that demand the ability to use model building, to help us work with both quantitative and qualitative aspects of a problem, together with its JOURNEY Making variant and its technical component of cognitive mapping (Ackermann \& Eden, 2001), which is useful in problem definition as well;

- Strategic Choice Approach (SCA)(Friend \& Hickling, 1987; Friend, 2001) to deal with interconnectedness and to manage uncertainty; and

- Multi-methodology that employs more than one quantitative / qualitative method or methodology in tackling some real-world problem (Mingers \& Gill, 1997; Mingers \& Rosenhead, 2001; Mingers, 2011).

According to Mingers (2011), Soft OR is not recognised as a legitimate part of OR everywhere. According to our knowledge, SSM has already been included in the courses on systems theory and innovation management; other above-mentioned methods and methodologies, however, have been paid attention to in only selected parts of the world, for example, in the United Kingdom and India (see, e.g., Mingers, 2011). Traditional, mathematically-based decision analysis methods and methodologies should be completed also with SODA, SCA and multi-methodology to tackle complex, wicked problems.

At the postgraduate level, a student acquires a thorough and systematic understanding of decision analysis in business sciences regarding problem structuring methods, multicriteria decision making and solution implementation.

It has already been shown that creative approaches are not limited to merely problem definitions and problem structuring (Čančer \& Mulej, 2013). In postgraduate studies, selective deepening can be in the use of creative thinking in typically analytical phases of the framework procedure of MCDM, e.g. in the establishing of the criteria weights (Čančer, 2012; Čančer \& Mulej, 2013) and in considering interactions, i.e. synergies and redundancies, among criteria. 
V. Čančer: Creative Problem Solving Techniques in Undergraduate and Postgraduate Economic and Business Studies

\section{Performance}

\subsection{Type of the course}

The inclusion of selected traditional and modern methods for strengthening creativity into several courses that are offered at business programs has proved fruitful; however, these courses are usually limited only to some selected study fields. To overcome this deficiency, Creative Problem Solving Methods can be developed as an elective course at the undergraduate study. In postgraduate studies, however, it can be developed as a compulsory course of the decision making group or as an elective course.

\subsection{Duration, learning and teaching methods}

At the undergraduate level, the course can run for 30 weeks (or 15 weeks). The direct pedagogical work can include two hours (or four hours) per week.

Among learning and teaching methods, lecturing, teaching with the case method, and active group work with discussion are at the forefront at the undergraduate level. At the beginning of each meeting, the teacher gives lectures, with the emphasis on student participation (e.g. when tying together topics from the last meeting, repeating topics, making connections between topics that have already been studied). When dealing with the first and the second phase of the CPS process, with a problem/opportunity definition and with generating ideas, the meeting continues with exercises (tutorials). Each technique is performed on the case study. Special attention is given to group work when appropriate. However, a distinction is being made between individual (e.g. wishing) and group techniques (e.g. brainstorming), and even between individual and group phases of the group techniques (e.g. nominal technique). When a technique can be performed individually or in groups, the advantages of interdisciplinary cooperation (as the opposite of the over-specialization) are put into forefront. Most often, not more than two creative techniques are planned per meeting (two hours).

Computer technologies are used to facilitate teaching of CPS. For computer-supported problem solving, computer programs are presented to students in a lecture room fully equipped with computers. Then, students solve the problem of the case study by using computer support. The use of computer support is more intensive in the third phase of the CPS process, in the decision-making phase. The student's commitments that are assessed are seminar work and its presentation, activities with tutorials, and a written examination.

At the postgraduate level, however, the direct pedagogical work should exceed eight hours of lectures; to strengthen group work and to facilitate seminar work based on the real-life application in the economic-business practice, we propose 12 hours of tutorials. With four hours per meeting, direct pedagogical work should encompass one week. 
$1^{\text {ST }}$ INTERNATIONAL SCIENTIFIC CONFERENCE $\gg$ TEACHING Methods FOR ECONOMicS AND BUSINESS SCIENCES"

V. Čančer: Creative Problem Solving Techniques in Undergraduate and Postgraduate Economic and Business Studies

Among learning and teaching methods, lecturing, case studies, active research work and discussion, together with problem solving are at the forefront at the postgraduate level. Since the number of direct pedagogical work (lectures) is lower at the postgraduate level as compared with undergraduate level, teacher's lectures should be compressed into four hours blocks, with a greater emphasis on students' participation (e.g. when making connections between topics that have already been studied at other courses, giving cases of application possibilities of several techniques, discussing other similar approaches). The meetings should continue with tutorials; their aim is to facilitate seminar work based on the real-life application in the economic-business practice by strengthening group work. One of key/transferrable skills at the postgraduate level is that a problem solver can lead and work effectively with group; can define and structure holistic business decision problems and handling conflict with confidence.

The student's commitments which are assessed are seminar work and its oral presentation, and oral or written examination. The seminar work is an autonomous work written individually or in groups (with from two to four participants, exceptionally up to six). The real-life problem found or/and defined by the students is solved with several selected creative problem solving methods. When needed, additional instructions are given or an opinion is expressed by the teacher. The difference between undergraduate and postgraduate level is reflected also in the topics of seminar works. Selected example cases of business CPS in undergraduate studies are as follows: the use of the $\mathrm{W}$ technique for the definition of the problem of choosing mutual funds (MCDM); the use of the six questions technique for a creative problem definition in selecting printing media (MCDM); creative thinking (W, mind mapping, fishbone diagram; morphological analysis, attribute listing) and deciding about the types of advertising (MCDM); the selection of CRM (W, AHP). In postgraduate studies, the proposed selected topics of seminar works include consumer preference measurement (factor analysis and MCDM), modeling consumer behavior (cognitive mapping and MCDM), the use of SCA in the structuring of the renovation of the service program, the use of SODA and MCDM for the structuring and selection of the most appropriate organization type, and e-commerce with MCDM.

Additional literature includes several selected real-life applications of creative techniques and MCDM in CPS in enterprises by phases (e.g. Čančer, 2012; 2014; Čančer \& Mulej, 2013).

\section{Conclusion}

Graduate students should be able to operate in complex and unpredictable specialized contexts and to exercise initiative and personal responsibility in professional practice. Because they have in-depth and systematic understanding of the knowledge in their specialized study fields and across them, and because they usually have more work experience than undergraduate students, graduate students can use CPS methods to solve specialized real-life problems, e.g. the ones that require a problem definition in MCDM, 
V. Čančer: Creative Problem Solving Techniques in Undergraduate and Postgraduate Economic and Business Studies

and implement the results in practice. In comparison with their undergraduate colleagues, they should be able to design or develop new approaches for new situations.

The syllabus outline can be completed regarding the students' interests and the specifics of the practical problems they are faced with in their real-life situations in economic and business practice. The selective deepening part of the course enables problem solving supported by several qualitative and quantitative methods and methodologies which we see as a step forward toward multi-methodology.

\section{Notes}

1 Some of problem definition techniques can be used also for idea generation (e.g. the W technique, mind mapping). When the alternatives (ideas/opportunities/solutions) are not yet developed, the techniques of the second CPS phase can be included in selective deepening as well.

\section{References}

Ackermann, F., \& Eden, C. (2001). SODA - Journey making and mapping in practice. In J. Rosenhead \& J. Mingers (Eds.), Rational analysis for a problematic world revisited: Problem structuring methods for complexity, uncertainty and conflict (pp. 43-60). Chichester, New York, Weinheim, Brisbane, Singapore, Toronto: John Wiley \& Sons, Ltd.

Belton, V., \& Stewart, T. (2010). Problem structuring and multiple criteria decision analysis. In M. Ehrgott, J. R. Figuiera, \& S. Greco (Eds.), Trends in Multiple Criteria Decision Analysis (pp. 209-240). New York, Dordrecht, Heidelberg, London: Springer.

Butler, S. A. (2010). Solving business problems using a lateral thinking approach. Management Decisions, 48, 68-64.

Checkland, P. (1981). Systems thinking, systems practice. Chichester: John Wiley \& Sons.

Checkland, P. (2001). Soft systems methodology. In J. Rosenhead \& J. Mingers (Eds.), Rational analysis for a problematic world revisited: Problem structuring methods for complexity, uncertainty and conflict (pp. 61-89). Chichester, New York, Weinheim, Brisbane, Singapore, Toronto: John Wiley \& Sons, Ltd.

Churchman, C. W. (1967). Wicked problems. Management Science. 14, B141-B142.

Cook, P. (1998). Best practice creativity. Hampshire: Gower Publishing Limited.

Čančer, V. (2014). Teaching creative problem solving methods to undergraduate economics and business students. Journal of Further and Higher Education, 38(4), 485-500.

Čančer, V., \& Mulej, M. (2013). Multi-criteria decision making in creative problem solving. Kybernetes, 42(1) 67-81.

Čančer, V. (2012). Criteria weighting by using the 5Ws \& H technique. Business Systems Research Journal, 3(2), 41-48.

Čančer, V., \& Mulej, M. (2010). The Dialectical Systems Theory's capacity for multi-criteria decision-making. Systems Research and Behavioral Science, 27(3), 285-300.

Eden, C., \& Ackermann, F. (2001). SODA - The principles. In J. Rosenhead \& J. Mingers (Eds.), Rational analysis for a problematic world revisited: Problem structuring methods for complexity, uncertainty and conflict (pp. 21-41). Chichester, New York, Weinheim, Brisbane, Singapore, Toronto: John Wiley \& Sons, Ltd.

Friend, J. (2001). The strategic choice approach. In J. Rosenhead \& J. Mingers (Eds.), Rational analysis for a problematic world revisited: Problem structuring methods for complexity, 

AND BUSINESS SCIENCES «

V. Čančer: Creative Problem Solving Techniques in Undergraduate and Postgraduate Economic and Business Studies

uncertainty and conflict (pp. 115-149). Chichester, New York, Weinheim, Brisbane, Singapore, Toronto: John Wiley \& Sons, Ltd.

Friend, J. K., \& Hickling, A. (1987). Planning under pressure. Pergamon Press: Oxford.

Harlim, J., \& Belski, I. (2013). Long-term innovative problem solving skills: Redefining problem solving. International Journal of Engineering Education, 29(2) 280-290.

Im, H., Hokanson, B., \& Johnson, K. K. P. (2015). Teaching creative thinking skills: A longitudinal study. Clothing and Textiles Research Journal, 33(2), 129-142.

Isaksen, S. G., Dorval, K. B., \& Treffinger, D. J. (1994). Creative approaches to problem solving. Dubuque, IA: Kendall/Hunt.

McWilliam, E., \& Haukka, S. (2008). Educating the creative workforce: new directions for twentyfirst century schooling. British Educational Research Journal, 34(5), 651-666.

Mingers, J. (2011). Soft OR comes of age - but not everywhere. Omega, 39(6), 729-741.

Mingers, J., \& Gill, A. (1997). Multimethodology: The theory and practice of combining management science methodologies. Chichester, New York, Weinheim, Brisbane, Singapore, Toronto: John Wiley \& Sons.

Mingers, J., \& Rosenhead, J. (2001). An overview of related methods: VSM, system dynamics, and decision analysis. In J. Rosenhead, \& J. Mingers (Eds.), Rational analysis for a problematic world revisited: Problem structuring methods for complexity, uncertainty and conflict (pp. 268-88). Chichester, New York, Weinheim, Brisbane, Singapore, Toronto: John Wiley \& Sons, Ltd.

Saaty, T. L. (2005). Creative thinking, problem solving \& decision making. Pittsburgh: RWS Publications.

Vidal, R. V. V. (2010). Creative problem solving: An applied university course. Pesquisa Operacional, 30(2), 405-426.

Wood, D., \& Bilsborow, C. (2014). 'I am not a person with a creative mind': Facilitating creativity in the undergraduate curriculum through a design-based research approach. The Electronic Journal of e-Learning, 12(1), 111-125. 


\title{
Selected Methods of Practical Teaching in Polish Higher Education
}

\author{
RoBERT KuCĘBA, WALDEMAR JęDRZEJCZYK, EDYTA KulEJ-DUdEK, BEATA BUTRYN \& \\ ANNA KUROPKA
}

\begin{abstract}
The article shows the important role of selecting a proper method of working with students, didactic resources as well as a proper form of student work. The authors indicate in it the application of problem solving and activating methods which activate student activeness and contribute to skills and competencies development. Several sample practical teaching methods applied while working with students are presented in it. Each method has been described with reference to its characteristic features, implementation stages and the results achieved through its application. The authors have also summarized the application of selected practical teaching methods.
\end{abstract}

Keywords: - skills - competencies - methods of practical teaching • problem solving methods $\bullet$ activating methods $\bullet$

Correspondence Addresses: Robert Kucęba, Ph.D., Czestochowa University of Technology, Armii Krajowej 19B Avenue, 42-201 Częstochowa, Poland, e-mail: robertkuceba@wp.pl. Waldemar Jędrzejczyk, Ph.D. Associate Professor, Czestochowa University of Technology,Armii Krajowej 19B Avenue, 42-201 Częstochowa, Poland,e-mail: waldekj@zim.pcz.pl. Edyta KulejDudek, Ph.D., Assistant Professor, Czestochowa University of Technology,Armii Krajowej 19B Avenue, 42-201 Częstochowa, Poland,e-mail: edku@zim.pcz.pl. Beata Butryn, Ph.D., Assistant Professor, Wrocław University of Economics, Ul. Komandorska 118-120, 53-345 Wrocław, Poland, e-mail: beata.butryn@ue.wroc.pl. Anna Kuropka, M.Sc., Ph.D. student, Wrocław University of Economics, Ul. Komandorska 118-120, 53-345 Wrocław, Poland, e-mail: anna.kuropka@ue.wroc.pl. 
$1^{\text {ST }}$ INTERNATIONAL SCIENTIFIC CONFERENCE $\gg$ TEACHING Methods FOR ECONOMicS AND BUSINESS SCIENCES«

R. Kucęba, W. Jędrzejczyk, E. Kulej-Dudek, B. Butryn \& A. Kuropka: Selected

Methods of Practical Teaching in Polish Higher Education

\section{Introduction}

Information society and knowledge society determine many aspects of our lives. One of them is the need of learning throughout the whole life - the concept of Life-Long Learning and is related to the requirements concerning the employees' growth together with the constant scientific and technological progress. The society has to constantly improve their qualifications and take care of development of competences in order to maintain the position on the labour market. Learning throughout the whole life is a key issue to remain professionally active even at an older age. The Life-Long Learning concept is a leading element of the Lisbon strategy, announced in 2000 by the European Union. According to it, education is one of the most important components contributing to the EU economy becoming the most competitive and dynamic economy in the world.

The time of studying significantly affects the system of values and attitudes of students, determining not only their initial expectations and aspirations that accompany their entry to the labour market, but also their attitude to life. University graduates, when they become employed on the labour market, are characterized by particular attitudes, and they also possess knowledge, skills and competences acquired at particular levels of education. Therefore, a proper selection not only of methods of working with students but also of proper didactic resources and forms of student work are of vital importance.

The main goal of this article is to identify and characterize practical teaching methods which are most frequently used in the educational process at universities.

\section{Organizational forms of the teaching process}

We learn and develop in all the areas of life in the course of our whole lives. However, university studies are the form of learning which prepares students for professional life. Apart from students' acquiring knowledge of the professional domain's instrumental knowledge, the goal of studies is also to prepare them for active participation in the society, acquiring the ability to adapt to the changing requirements of the labour market and the possibility to function successfully in the professional and social world. These elements are influenced by a proper selection of forms, methods and didactic resources as well as the quality of teaching at the given university.

Education quality development systems at universities are presently becoming one of the main factors of building a strong competitive position on the more and more demanding market of educational services. The growing demands are conditioned by (Banaszyk, 2008, p. 181):

- an increased number of competing universities, which is the result of nonpublic universities sector emergence,

- cross-border competition from foreign universities, 
R. Kucęba, W. Jędrzejczyk, E. Kulej-Dudek, B. Butryn \& A. Kuropka: Selected Methods of Practical Teaching in Polish Higher Education

- more and more significant drop in the number of candidates for stationary courses caused by acquiring student age by the generation of demographic decline.

Learning is most frequently identified as formal education carried out, for example, by a university. Teachers who run classes while organizing the teaching process can use various methods and techniques by means of which it is possible to achieve particular educational goals. The portfolio of forms, techniques and methods is very wide. Particular tools can be used in different ways at each educational level. However, more stress is put on independence and growing involvement of learners in the organization of the teaching process. Studying involves not only being present in classes on the schedule, but it also consists of exploring the issues discussed in the course of formal teaching through consolidation and broadening of previous knowledge during informal and non-formal education.

At Polish universities, there are several organizational forms of classes for students. The most popular of them include: lectures, subject classes, laboratory classes, seminars and projects. Each form of carrying out these forms (i.e. the didactics) has its specificity, offers various possibilities, and requires the teacher to possess different skills and different ways of preparing for classes. The way of running classes is also largely influenced by the number of students in the group, their level of knowledge and expectations towards classes (Kaszuba-Perz, \& Perz, 2010, p. 48).

Lecture is the basic, traditional organizational form of classes at universities, which makes it possible to pass logically ordered contents in a form accessible for a larger number of students. Frequently, teachers also provide additional examples which help students to understand and remember a given material. Each lecture can be conducted differently. Usually, it takes the conventional form, where students are provided with ready contents of the lecture to memorize. It can take the form of a problem lecture, which requires mental involvement of the students in the course of formulating problems and searching for solutions (Andrzejczak, 2014, p. 22-23). Other distinguished organizational forms of classes have been presented in the further part of the paper in the context of practical teaching methods applied in formal teaching at the selected university in Poland.

\section{$3 \quad$ Portfolio of practical teaching methods - case study}

Employees of the Czestochowa University of Technology (members of the project team) conducted in 2016 studies at the mother university, the aim of which was to identify the forms and methods applied in the teaching processes. The studies were conducted within the project 'The acceleration method of development of transversal competences in the students' practical training process', carried out in cooperation with Poznan University of Technology (Poland), Wroclaw Economic University (Poland), Western Chamber of Industry and Commerce in Gorzow Wielkopolski (Poland), Centria ammattikorkeakoulu (Finland), JEDU Jokilaaksojen koulutuskuntayhtymä (Finland), 
$1^{\text {ST }}$ INTERNATIONAL SCIENTIFIC CONFERENCE »TEACHING Methods FOR ECONOMICS AND BUSINESS SCIENCES«

R. Kucęba, W. Jędrzejczyk, E. Kulej-Dudek, B. Butryn \& A. Kuropka: Selected

Methods of Practical Teaching in Polish Higher Education

Univerza v Mariboru (Slovenia) and Univerzita Mateja Bela v Banskej Bystrici (Slovakia).

The portfolio of practical teaching methods in formal education contains: problemsolving methods, activating methods, demonstrating methods, programmed methods and practical methods. The group of problem-solving methods includes methods such as: brainstorming, observation, panel discussion, problem lectures, metaplan, management training, business narrative and case study. The group of activating methods used in formal practical education in Poland includes: case study, staging, management training and business narrative. The portfolio of practical teaching methods in formal learning also contains, as it has already been noted, demonstrating methods such as: shows, psychodramas, management training, business narrative and educational simulation games. Currently, it is very common for formal practical education processes to widely employ diverse programmed methods, which are not merely limited to using a handbook or a computer. Polish institutions of higher education make an extensive use of e-learning solutions (both off-line and on-line). E-learning platforms are often created in the MOODLE environment. In the case of practical methods, summarized also in the portfolio of practical teaching methods in formal learning, classes run adopt various forms. They include practical classes, laboratory classes, production classes, project methods, seminars, simulation, management training and business narrative (The report concerning applied teaching methods of transversal skills and methods of practical trainings, 2016, pp. 53-54).

One of the common forms of courses is classes. Their goal is to enable students to systematically acquire knowledge with better understanding, thanks to discussing the topics during classes, acquiring certain practical by solving tasks, problems and discussions (Andrzejczak, 2014, p. 23). In the case of practical classes, which in formal practical teaching make up $57.53 \%$ in reference to all summed-up types of classes, the most popular teaching method is a case study $-61.90 \%$. High rates in reference to all teaching methods used in practical classes were obtained for the following methods: panel discussion $-36.90 \%$, and problem lecture $-30.95 \%$. Referring further to programmed methods, methods employed using computers are more popular - $29.76 \%$, in comparison with the methods employed using a book $-28.57 \%$. Currently, the difference is only $1.19 \%$. Laboratory classes in technical fields of study make up $15.76 \%$ in reference to all summed-up types of classes. The most popular practical teaching method in formal education is the programmed method - using a computer, which makes up $86.95 \%$. Computers with specialized subject-related software are the basic equipment of laboratory workstations, which allows the reflection on the real work environment. In the case of laboratory classes, demonstrating and activating methods are also commonly used, in particular shows $-43.47 \%$, and a case study $-26.08 \%$. Currently, one can observe in formal practical teaching a dynamic increase (13.04\%) in the use of simulation games while working with students during laboratory classes. This concerns, in particular, MMOG (massively multiplayer online game). To complement the use of the abovementioned practical teaching methods during laboratory classes, other methods are used, such as: brainstorming, observation, panel discussion, problem lecture, staging, and 


\section{R. Kucęba, W. Jędrzejczyk, E. Kulej-Dudek, B. Butryn \& A. Kuropka: Selected Methods of Practical Teaching in Polish Higher Education}

mobile apps whose share stands at the level of $4.34 \%$ (The report concerning applied teaching methods of transversal skills and methods of practical trainings, 2016, p. 5657).

Within the project classes, students develop their own projects on a selected topic, working independently or in small project teams. The project methods' share in reference to all the summed-up types of classes is at the level of $23.28 \%$. In the case of project methods used in formal practical education, tutors, in particular, introduce case studies $58.82 \%$ as a reflection of the practical aspects of business and students' future work. Project methods are often employed using a computer $-55.88 \%$, including e-learning solutions $-5.88 \%$. Groups of problem-solving, activating and demonstrating methods also use: metaplan $47.05 \%$, panel discussions $-29.41 \%$, shows and problem lectures $11.76 \%$. Project methods also employ simulation games $-5.88 \%$ and mobile applications (The report concerning applied teaching methods of transversal skills and methods of practical trainings, 2016, p. 57).

Other methods requiring large student involvement form of courses are diploma and master seminars, in the course of which students carry out their own research work on a particular topic. The final effect is a ready diploma or master's thesis. The goal of the seminar is to make students acquainted with particular stages of independent research work - from formulating the research goal and problem to the method of gathering and analysing the research material (Andrzejczak, 2014, p. 23-24). The share of this type of classes in reference to all the summed-up types of practical methods stands at the level of $3.43 \%$. Formal practical education employs, during seminars, problem-solving methods, activating methods and demonstrating methods. In particular, due to the above-quoted function of seminars in the formal practical education, the following methods are used: panel discussions, problem lectures, and metaplan. The unit contribution of these methods to seminars is $80 \%$.

The results of the conducted research are included in full in 'The report concerning applied teaching methods of transversal skills and methods of practical trainings' (2016).

\section{Characteristics of selected practical teaching methods applied at the Czestochowa University of Technology}

\subsection{Brainstorming}

Brainstorming is one of heuristic methods. These are methods of creative problem solving. The goal of brainstorming is to improve group decisions, frequently used as a form of a didactic discussion or one of teaching methods. It is included into activating methods in the sub-group of problem methods. It engages all the participants, providing each of them with an opportunity to express themselves freely. This method consists of the possibility of a quick accumulation of numerous, differentiated solutions to the assigned problem in a short time. It stimulates creative thinking of the participants. 
R. Kucęba, W. Jędrzejczyk, E. Kulej-Dudek, B. Butryn \& A. Kuropka: Selected

Methods of Practical Teaching in Polish Higher Education

Particularly important here is moving away from patterns and using experience coming from different domains, even if they do not seem related to the problem domain at first sight.

Brainstorming includes the three stages:

- Preparation/Introduction;

- Session of ideas/Collecting ideas;

- Analyzing and evaluating ideas.

The session participants include:

- The moderator who runs the session and makes ongoing records of the session (there can be two moderators as well):

- Stakeholders: the student group divided into three test groups.

The moderator conducting the session controls that the determined rules are adhered to. Session duration:

1. Introduction - selecting a proper number of students, discussing the principles of the session by the moderator, discussing the problem - up to 45 minutes.

2. Generating ideas (according to the given topic) - until students run out of ides, in practice no longer than 45 minutes.

3. Another meeting during which the moderator consolidates the lists generated during the session of ideas, dividing them into categories - up to 15 minutes.

4. Reducing ideas and assigning priorities to them - about 30 minutes.

The course of brainstorming:

\section{Preparation/Introduction}

The first step is the selection of a proper number of participants, choosing the moderator/leader and the person to record the ideas. The task of the leader is to organize and run the session. The moderator prepares the participants to understand the problem that they are supposed to solve (through, e.g., lecture, talk, working with text). The moderator communicates the group rules of work, indicates the necessary materials, explains the doubts that the participants may have with relation to the rules and problem which is the subject of the meeting. The task of the moderator is also to acquaint the students with the rules of brainstorming.

\section{Ingenuity session/Collecting ideas}

Students are encouraged to freely submit the ideas to solve the presented problem. They submit ideas, which the moderator or the appointed person records on the board. Each 
time only one idea can be submitted, which is meant to prevent the situation when only more ingenious students speak, at the expense of the others. In the case when the process of submitting the ideas comes to a standstill, the moderator can ask guiding questions (using a special list of guiding questions), thus encouraging the participants to submit the combinations of previously submitted ideas or to develop them. The moderator can all the time ask questions that activate the students. At the end of the session, the moderator encourages the participants to submit final ideas. Its end is determined by a significant decrease in the number of submitted ideas or the moderator's decision that the collected material is comprehensive and allows to solve the problem.

\section{Analysis and evaluating the ideas}

Evaluation of the ideas takes place after all the proposals are submitted. The participants should group similar ideas into relevant categories. Then, each solution is being discussed and evaluated. Together with the moderator, the participants select most accurate solutions to the problem and justify their opinion. The best solution can be put into practice and assessed with regard to its effectiveness.

Brainstorming can be applied for various classes, lectures, laboratories and project work, as application of this method fosters the ability of creative thinking and behaviour. At the Czestochowa University of Technology, this method is used during classes at the $1^{\text {st }}$ and $2^{\text {nd }}$ level of full-time studies and extramural studies in various courses. Sample subjects that make use of this method include, among others: Management, Methods of Organization and Management, Sciences of Organization, Marketing, Organizational Behaviours, Basics of Management, Human Resources Management. This method is very popular and frequently applied by lecturers. Brainstorming is used in formal, informal and non-formal teaching. The results of the study shows that within formal teaching in subject classes the method is applied in $4,76 \%$, laboratory classes $4,34 \%$ and project classes $14,7 \%$. In informal teaching, the use of brainstorming has been indicated by scientific associations and student organizations. In non-formal teaching, this method is used during courses and trainings.

\subsection{Group work}

One of problem methods activating students to act is group work. The goal of group work is to identify the differences of individual students and also shaping their knowledge, general abilities (among others, the ability to cooperate in a group, ability to communicate, critical thinking ability), attitudes as well as learning one from another and combining the abilities of particular students while carrying out a particular task. A group is a set of individuals subordinate to common goals and able to cooperate together. The group is not just a sum of particular individuals - the group offers grater possibilities and creates a totally new quality. Particular individuals in the group change their behaviour and act differently than they would if they worked alone. Selection of the group depends on the type of task that is to be performed, but best results are achieved 
$1^{\text {ST }}$ INTERNATIONAL SCIENTIFIC CONFERENCE $\gg$ TEACHING Methods FOR ECONOMicS AND BUSINESS SCIENCES«

R. Kucęba, W. Jędrzejczyk, E. Kulej-Dudek, B. Butryn \& A. Kuropka: Selected Methods of Practical Teaching in Polish Higher Education

by small groups ( 4 to 5 persons), of mixed sexes. Group work is characterized primarily by the cooperation of task performers - cooperation, helping one another, advice, fulfilling various functions and also joint responsibility for the results of the work. An important advantage of group work is an increase of knowledge and experiences within the group. This form of activeness provides activating stimuli and facilitates the socialization of group participants. A significant stress while applying this method should be put on multidimensional communication within the group. Members of the group communicate with the teacher and also with other members of the group, which makes it easier to agree on the position or it deepens the relationships within the group.

At the Management Faculty of the Czestochowa University of Technology, this method is applied in classes both at the $1^{\text {st }}$ and $2^{\text {nd }}$ level of full-time and extramural courses of different fields of studies. Sample subjects carried out with the use of this method include: Management, Methods of Organization and Management, Sciences of Organization, Marketing, Organizational Behaviours, Basics of Management, Human Resources Management.

The goal of running classes with the use of the group work method is to develop the ability to cooperate, make decisions, encourage the students to be creative while solving problems, satisfy the needs connected with cognitive activeness as well as social and emotional ones and integrate the group and activate its members to creative and entrepreneur activity. Working within a group requires division of tasks and responsibilities among the group members. Each of the members receives the tasks to perform from the teacher, and is responsible for them. Groups perform work fast, more efficiently thanks to the support provided by other members of the group. Group work is an opportunity to widen ones' competences and knowledge, using the experiences and skills of the other group members. Important aspects of group work include partner interpersonal relationships, equal rights to participate in the work of the group, considering various beliefs and ideas and arriving at the accepted by all the members, realistic solution. It requires that the equality of rights while submitting the ideas is maintained and assumes mutual responsibility for decisions that have been made.

Stages of group work in the classes:

1. Introduction - the teacher divides the students into groups, formulates goals of work, and indicates the ways of achieving them. He does not limit the ingenuity of the students, instead tries to guide them to search for individual ways of achieving the set goals. The teacher assigns particular tasks.

2. Action - students, supported by the teacher, work in groups according to the assigned task following the accepted plan and division of work and responsibilities.

3. Summary - this should concern acquired information and efficiency and presenting the results of group work. Remarks can be written on result sheets and then discussed with the students with reference to what new experiences they have gained and what results of work they have obtained, and so on. 
R. Kucęba, W. Jędrzejczyk, E. Kulej-Dudek, B. Butryn \& A. Kuropka: Selected Methods of Practical Teaching in Polish Higher Education

4. Group evaluation - students present and discuss the results of their work and also evaluate the completed tasks. They evaluate the quality of work, verify whether they completed the task successfully and whether they achieved goals set by the teacher. Students evaluate which stages of work were completed in a better way than it had been assumed and which require improvement. They discuss the reasons of success or failure.

5. Individual evaluation - each of the students individually evaluates their participation in the group work, their weaknesses and strengths and the level of mastering skills and competences necessary to complete the task, with particular stress on transversal competences.

All newly acquired experiences and conclusions can be used to perform a similar task in the future. While analyzing particular stages of the performed task, one can validate the usefulness of introduced changes, which will allow further evaluations to be conducted. In this way teaching can acquire cyclical nature. Group work motivates the team members to act, as their individual participation increases the work efficiency of the whole group. It teaches cooperation, respecting the accepted principles and discipline and allows shared responsibility to be felt. It also enables to improve communicative competences through expressing one's opinion, listening to other students, exchanging experiences in the course of common work. It also facilitates activation and has an inspiring effect on the other team members. The confrontation of various opinions is a very frequently occurring element in the course of group problem solving, as a result of which cognitive activeness of students is promoted, which consequently leads to new ways of thinking, in this arguing, explaining, formulating thoughts and acting. A positive result of group work is also developing the feeling of unity and cooperation with the team, which inhibits the development of individual competition.

\subsection{Wykład problemowy}

Lecture belongs to the group of presentation methods, i.e. the methods of assimilating knowledge based primarily on cognitive activeness of reproductive nature. Lecture is one of the most frequently used and one of the simplest (both for the listeners and the teacher) teaching methods applied in higher education in which the person passing the knowledge conducts an extensive speech on a given topic. It requires the listeners to memorize a large amount of information, as well as possessing significant mental maturity and understanding the cause and result dependencies. Apart from the substantive competence the lecturer should know how to relate the content of the lecture with real life and selects accurate and interesting examples.

Problem lecture is a word-based method. It belongs to the group of problem methods, i.e. methods of independent acquisition of knowledge, based on creative cognitive activeness, which consists in solving problems. In contrast to conventional lecture, where the content is presented by the lecturer in the form which is ready to memorize, problem lecture reflects a scientific or practical problem. The way in which a given subject is taught is 
$1^{\text {ST }}$ INTERNATIONAL SCIENTIFIC CONFERENCE $\gg$ TEACHING METHOdS FOR ECONOMICS AND BUSINESS SCIENCES«

R. Kucęba, W. Jędrzejczyk, E. Kulej-Dudek, B. Butryn \& A. Kuropka: Selected

Methods of Practical Teaching in Polish Higher Education

most frequently a series of lectures in a given semester which are thematically related and which present the discussed issues from different perspectives. In case of problem lecture, the discussed issues may concern various grasps of the set problem, its history and ways of solving it and also detailed and full explanation of the given problem domain. It is applied when contents of the lecture are concentrated around certain problems. Problem lecture is characterized by maintaining a broader contact between the lecturer and students, which is reflected in careful, active following the lecture's reasoning and thinking concurrently with the teacher. The lecturer during the lecture expresses their thoughts, allowing students to participate in gathering incentives, follow his course of thinking: from understanding the nature of the problem to the moment of solving it.

This method is often applied in formal teaching, but also in informal one (used by scientific associations, student organizations as well as during conferences, symposiums or lectures of representatives of the world of science, politics and business) and nonformal one (courses, trainings). This method applied in the course of practical teaching allows for acquisition of extensive knowledge and its later use in professional practice. Practical methods are used to comprehensively develop skills and competences of effective functioning in real conditions of business activity. The percentage index of the distinguished method of practical teaching share (problem lecture) in formal teaching in subject classes amounts to $30.95 \%$ with reference to all summarized types of classes. Problem lecture is applied in almost all subjects taught at the Czestochowa University of Technology.

Problem lecture is a good teaching method if there is a need to acquaint students with a particular domain, but also to present more detailed issues which are the continuation of a previous lecture. Problem lecture is also successful in transferring knowledge in the form of a series of definitions, standards, regulations, formulas and procedures. However, this is not a satisfactory method to memorize well and understand issues being taught. It should be remembered that in order to consolidate knowledge in a given scope other methods will be more effective, as they require active participation of students in the classes rather than just passive acquisition of the transferred knowledge.

A description of all the above methods was elaborated within the EU funded project 'The acceleration method of development of transversal competences in the students' practical training process'.

\section{$5 \quad$ Conclusions}

In contemporary didactic system, the selection of teaching methods depends, among other, on goals, contents and didactic tasks. Teaching method selection criteria are not unambiguously defined. They are of a guiding nature, indicating main tendencies. Therefore, teachers should not limit themselves to one type of methods as such approach will not ensure good results of didactic work. 
The application of activating teaching methods requires from the teacher a greater ingenuity, increased involvement in the teaching process as well as additional preparation for classes. Their application in the teaching process leads to strengthening competences in the scope of communicativeness, creativity and entrepreneurship and it strengthens the relationships during the group work. These methods also develop student abilities in the scope of independent problem solving and applying the acquired knowledge in practice. They activate cognitively and affect imagination of group members. Thanks to this, in the course of performing tasks students acquire the skill of group cooperation, participate in common activities and gain satisfaction from the fulfilled roles, having the feeling of being a member of the group.

Thus, the distinguished methods develop the ability to communicate and cooperate, allow abilities and skills to be developed, help to become responsible for one's decisions, make it possible to learn from others, increase the involvement and motivation to work, and also encourage participation in open discussions and undertaking new tasks.

\section{References}

Andrzejczak, A. (2014). Uczelnia jako miejsce zdobywania wiedzy i doświadczeń - kultura studiowania. In A. Andrzejczak (Ed.) Metodyka studiowania. Poznań: Wyd. UE w Poznaniu.

Banaszyk P. (2008). System kształtowania jakości kształcenia w Akademii Ekonomicznej w Poznaniu. In (ed.) J. Dietl, \& Z. Sapijaszka, Studia ekonomiczne - czy tylko wiedza $i$ umiejętności?. Łódź: Fundacja Edukacyjna Przedsiębiorczości.

Kaszuba-Perz A., Perz P. (2010). Przygotowanie do zajęć. In A. Rozmus (Ed.), Wykładowca doskonaty. Warszawa: Oficyna Wolters Kluwer Business.

The report concerning applied teaching methods of transversal skills and methods of practical trainings. (2016). Part of on-going Erasmus+ Programme project 'The acceleration method of development of transversal competences in the students' practical training process. Poznań. Retrieved from http://www.awt.org.pl/erasmus/do pobrania/?lang=en 
$1^{\text {ST }}$ INTERNATIONAL SCIENTIFIC CONFERENCE $\gg$ TEACHING METHOdS FOR ECONOMICS AND BUSINESS SCIENCES« 


\title{
Mindfulness: Does it Influence Students' Academic Success and Personal Wellbeing?
}

\author{
SONJA SIBILA LEBE, HERI ŠPIČKA
}

\begin{abstract}
Many students in higher education are experiencing stress and anxiety - both hinder their academic success, as well as their personal wellbeing. The authors thus decided to test whether regular mindfulness practice has the potential to decrease the students' feelings of anxiety and stress. Methodological approach consisted of tree stages: a) students were asked to fill in a questionnaire that was testing their self-respect, selfconfidence, and their abilities to learn and to concentrate; $b$ ) the poll was repeated after six weeks among students who participated at least ten times in the meditation; c) parallel, two teachers who initiated this research were observing possible changes in students' behaviour as result of the mindfulness meditation. Preliminary results show very encouraging results: more self-confidence by the students, a better communication between the professor and the students, as well as a noticeably higher level of attention/concentration, and a higher quality of discussions during the courses.
\end{abstract}

Keywords: - higher education • student opinion poll • self-esteem • anxiety and stress reduction $\bullet$ mindfulness meditation $\bullet$

Correspondence AdDresses: Sonja Sibila Lebe, Ph.D., Associate Professor, University of Maribor, Faculty of Economics and Business, Razlagova ulica14, 2000 Maribor, Slovenia, e-mail: sonjasibila.lebe@um.si. Heri Špička, B.Sc., Lecturer, University of Maribor, Faculty of Economics and Business, Razlagova ulica 14, 2000 Maribor, Slovenia, e-mail: heri.spicka@um.si. 
$1^{\text {ST }}$ INTERNATIONAL SCIENTIFIC CONFERENCE $\gg$ TEACHING Methods FOR ECONOMicS AND BUSINESS SCIENCES«

S. Sibila Lebe \& H. Špička: Mindfulness: Does it Influence Students' Academic

Success and Personal Wellbeing?

\section{Introduction}

\subsection{What is mindfulness?}

Mindfulness, as used in ancient texts, is an English translation of the Pali word sati, which connotes awareness, attention, and remembering. Pali is the language in which the teachings of the Buddha were originally recorded. The first dictionary translation of sati into 'mindfulness' dates to 1921 (Siegel et al., 2008).

The word 'mindfulness' can be used to describe a theoretical construct (mindfulness), a practice of cultivating mindfulness (such as meditation), or a psychological process (being mindful). A basic definition of mindfulness is "moment-by-moment awareness." Other definitions include: "Keeping one's consciousness alive to the present reality". "The clear and single-minded awareness of what actually happens to us and in us at the successive moments of perception"; "attention control"; "keeping one's complete attention to the experience on a moment-to-moment basis"; and, from a more Western psychological perspective, a cognitive process that employs creation of new categories, openness to new information, and awareness of more than one perspective. Ultimately, mindfulness cannot be fully captured with words because it is a subtle, non-verbal experience (Germer, 2004).

\subsection{Mindfulness definition}

As we shall see, the definition of 'mindfulness' has been somewhat modified for its use in psychotherapy, and it now encompasses a broad range of ideas and practices (Siegel et al., 2008). Primarily known as an element of the Buddhist tradition, the concept of mindfulness has gained, in more recent times, increasing attention in both scientific and lay communities (Chiesa, 2012).

Early conceptualizations of mindfulness can be found in traditional Buddhist scriptures such as the Abhidhamma and the Vishuddimagga. The Abhidhamma is a classic scholastic compilation of Buddhist psychology and philosophy, and the Vishuddimagga is a summary of the part of the Abhidhamma that deals with meditation. The original term of what is commonly referred to as mindfulness is Sati, a Sanskrit word that has been both used to indicate a lucid awareness of what is occurring within the phenomenological field and as a term that could be translated as 'remembrance' or memory. Indeed, mindfulness has traditionally been defined as an understanding of what is occurring, before or beyond conceptual and emotional classifications about what is or has taken place. Furthermore, mindfulness has also been defined as a development of one's own memory. This, in turn, is supposed to enhance the ability not to forget past experience so as to facilitate greater awareness and sense of purpose for one treading the ethical development emphasized by traditional mindfulness practices (Chiesa, 2012).

In the last 35 years, mindfulness is getting attention in psychology, medicine, and, recently, in education. It has become the focus of a large community of clinicians and, to 
S. Sibila Lebe \& H. Špička: Mindfulness: Does it Influence Students’ Academic Success and Personal Wellbeing?

a lesser extent, empirical psychology. Much of the interest in the clinical applications of mindfulness has been sparked by the introduction of Mindfulness-Based Stress Reduction (MBSR), a manualised treatment program originally developed for the management of chronic pain (Bishop et al., 2004), (Chiesa, 2012). Psychological support to patients with cancer by practicing mindfulness is reported by (Brown \& Ryan, 2003) and by (Carlson \& Brown, 2005).

\subsection{Mindfulness meditation}

Practicing mindfulness meditation has its roots in Eastern philosophical traditions (Schwind et al., 2017). Although various meditation practices are taught in mindfulness approaches to treatment, they are similar in their basic procedures and goals. A description of sitting meditation will illustrate the basic approach. The client maintains an upright sitting posture, either in a chair or cross-legged on the floor and attempts to maintain attention on a particular focus, most commonly the somatic sensations of her or his own breathing. Whenever attention wanders from the breath to inevitable thoughts and feelings that arise, the client will simply take notice of them and then let them go as attention is returned to the breathing. This process is repeated each time that attention wanders away from breathing. As sitting meditation is practiced, there is an emphasis on simply taking notice of whatever the mind happens to wander to and accepting each object without making judgments about it or elaborating on its implications, additional meanings, or need for action (Bishop et al., 2004).

The client is further encouraged to use the same general approach outside of his or her formal meditation practice as much as possible by bringing awareness back to the hereand-now during the course of the day. This can be achieved by using the breathing as an anchor, whenever the practitioner notices a general lack of awareness or whenever the attention has become focused on streams of thoughts, worries or similar. These procedures apparently lead to a state of mindfulness (Bishop et al., 2004).

\subsection{Mindfulness in education}

Life in today's society is becoming more and more stressful. Education is no exception: here, practicing mindfulness has first been adopted in nurse education (Schwind et al., 2017). Learning foreign languages integrated mindfulness in its teaching process, as well (Wang \& Liu, 2016).

Recently, mindfulness is becoming an important part of the education process in Slovenia, too (Orel, 2016), embracing all levels of education (from kindergarten till university studies). Medical students of Slovenia are using guided mindfulness meditation to overcome the stress associated with their studying (Zupančič, 2015). We know that not only the medical, but practically all students in higher education are experiencing stress and anxiety. This hinders their academic success and personal wellbeing. Different kinds of mindfulness practice and loving-kindness meditation have the potential to decrease 
$1^{\text {ST }}$ INTERNATIONAL SCIENTIFIC CONFERENCE $\gg$ TEACHING METHODS FOR ECONOMICS AND BUSINESS SCIENCES «

S. Sibila Lebe \& H. Špička: Mindfulness: Does it Influence Students’ Academic

Success and Personal Wellbeing?

students' negative feelings, to increase their self-confidence, and compassion for themselves and for others (Schwind et al., 2017).

\section{$2 \quad$ Methodology}

This paper is based on a case study performed at the Faculty Economics and Business, University of Maribor, Slovenia, within three selected courses in the summer semester of the academic year 2016/2017 (from February to June 2017). Two teachers, inspired by the 'International MINDfulness conference', organised in Ljubljana in October 2016, decided to introduce a short (10-minute) guided meditation for their students at the beginning of every lesson they hold during the summer semester. Students attending the second semester (first year of undergraduate study) experienced one meditation a week (during practical classes (tutorials) in Business Information Systems), whereas the students of semesters four and six (second and third year of undergraduate study) participated in the meditation twice a week (lectures and practical classes (tutorials) in tourism). The project has three phases: 1) Introductory lecture (first lecture in the semester) with explanations and first meditation, 2) Interim testing and report (the latter being a conference paper) after six weeks of practicing mindfulness, and 3) Final opinion poll and final report, including the report of teachers' observations.

Phase 1 was carried out in three steps. Step one happened within the first session of the summer semester: the two teachers who initiated this research explained to the students the purpose and the schedule of the project. In step two, the students were asked to fill in a questionnaire by rating 50 statements. They marked their level of agreement by using a 5-level Likert-type scale, where 1 meant complete disagreeing and 5 complete agreeing with the statement. To avoid marking the level 3 (neither-nor) when they were not sure about the answer (or did not wish to score a statement), we introduced a possibility of choosing 0 in case they would have no opinion or could not rate the statement due to other reasons (e.g. not understanding the meaning of the statement).

The questions were based on a combination of two already elaborated mindfulness questionnaires, namely the Five Facet Mindfulness Questionnaire Using a Rasch Approach (Medvedev et al., 2017), and the Mindful Attention Awareness Scale (MAAS) (Brown \& Ryan, 2003), from which we took some questions, and modified them. We upgraded this collection with some additional questions that explicitly tested possible feelings of anxiety and stress associated with educational process (lectures, exercises, exams, communication among students and communication between students and professors). Our aim was measuring different items as questionnaires meant to detect the moods of segments described in the literature (e.g. cancer patients); therefore, our clustering of questions was modified. Instead of Rasch's model (which clusters questions by focusing on a) observing, b) acting, c) non-judging, d) describing and e) non-reacting), our statements were testing the students': a) feelings (including self-esteem and selfrespect), b) attitudes and behaviour (e.g. towards their peers and/or professors), c) attentiveness and (conscious) awareness of the environment, d) behaviour and e) their ability to communicate (express their wishes/ thoughts). 
S. Sibila Lebe \& H. Špička: Mindfulness: Does it Influence Students’ Academic Success and Personal Wellbeing?

The third step in the introductory session was a short lecture on meditation: how to approach the practice, why it is good to meditate, and which the benefits associated with regular meditating are. This step concluded by taking for the first time part in a guided mindfulness meditation, following an audio file prepared by the Society of medical students of Slovenia (Zupančič, 2015). Students of all semesters $\left(2^{\text {nd }}, 4^{\text {th }}\right.$ and $\left.6^{\text {th }}\right)$ were also encouraged to perform individual mindfulness meditation on their own at home (link to the meditation is available online on YouTube, and was additionally sent by email to all students enrolled into the mentioned courses and is available in the Faculty of Economics and Business Moodle e-learning environment for Tourism subjects and for subject Business Information Systems).

The 10-minute meditation at the beginning of the session became a rule, and a regular part of the pedagogical process by the two teachers who also are the authors of this paper. The students are aware that this practice would continue until the end of the semester.

Phase 2 consisted of two steps: carrying out the second opinion poll, and preparing an interim report (in form of a conference paper). The questionnaire for the second poll comprised all statements from the first questionnaire, and was extended with 21 additional statements that were examining the students' attitude towards the mindfulness meditation and their experiences with its possible influence on their academic success and personal wellbeing. These statements were about feeling better, having more energy, being more efficient when learning, being better centred, having less conflicts with peers etc. We also added some negative statements, e.g. "I consider the introductory meditation being a waste of time"; "I feel uncomfortable when meditating in a group of peers" or "I would prefer not meditating any longer". On the other hand, we added some positive statements, e.g. "I started meditating at home as well"; "I inspired my friend(s) / family member(s) to start meditating" or "I intend to continue meditating even after the semester is over".

For the purpose of this paper, Phase 2 was performed towards the end of March 2017. The opinion poll was limited to the students of the second and third year of study only, thus to the students who participated in the mediation twice a week (therefore, the first results of practicing mindfulness could already be noticeable).

The first limitation of this research is, therefore, the fact that we are here presenting preliminary results (approximately half-time results), and the second one is the limitation to 25 regular participants of at least 10 meditation sessions.

Phase 3 will follow at the end of the lectures in the summer semester of 2017, and will consist of an opinion poll of the entire population that is included into the meditation project (129 students attending semesters 2, 4, and 6). We shall use the same questionnaire as in Phase 2. Final results will be available after the summer semester is completed (after 15 June, 2017). 
$1^{\text {ST }}$ INTERNATIONAL SCIENTIFIC CONFERENCE $\gg$ TEACHING METHOdS FOR ECONOMICS AND BUSINESS SCIENCES «

S. Sibila Lebe \& H. Špička: Mindfulness: Does it Influence Students’ Academic Success and Personal Wellbeing?

Throughout the project, both teachers were (and still are) observing the behaviour of the students, giving special attention to three points: 1) self-esteem of students (participation in debates, finding suitable words to appropriately describe their experiences and thoughts etc.), 2) concentration (being centred on the subject of the lesson, asking questions to get to know more about the matter), and 3) students' personal well-being (smiling, laughing, responding spontaneously to remarks etc.).

Not to lose the point, both teachers have, from time to time, mentioned some positive impacts of mediation: that it can augment the practitioners' self-esteem, their health condition, ability to communicate and to learn, which all affects their overall wellbeing.

The second research method in this project is observation: both teachers who are performing the meditation systematically observe its impact on their students. They observe their behaviour by following the three areas they have agreed on (mentioned above), trying to detect possible impacts of the mindfulness meditations.

\section{$3 \quad$ Research and preliminary results}

25 students have filled in the questionnaires 1 and 2. Statements were numbered from 1 to 50 , and from 1 to 71 respectively. The first 50 statements in both opinion polls were identical; the last 21 (numbered 51 to 71) in the questionnaire 2 were added to check the students' opinion on the meditation practice during the lessons. The participating students rated the statements by ticking values on a 5-degree Likert-type scale, where 1 meant completely disagree, and 5 meant completely agree; 0 was given as choice for no opinion (more in chapter Methodology).

The table below shows the evaluation of the statements as collected during the first and the second opinion poll (the first and the second row in the table respectively) by students attending the $4^{\text {th }}$ and the $6^{\text {th }}$ semester. Having to do with preliminary results, we did not elaborate a very extensive statistical analysis - this will follow after all results are available at the completion of the project. Albeit the data was gathered separately for the unique study years $\left(1^{\text {st }}, 2^{\text {nd }}\right.$ and $\left.3^{\text {rd }}\right)$ and separately for both sexes, we only present the cumulative values for both sexes and for the second and the third study year. 
$1^{\text {ST }}$ InTERNATIONAL SCIENTIFIC CONFERENCE $\gg$ TEACHING METHOdS FOR ECONOMICS AND

BuSINESS SCIENCES«

S. Sibila Lebe \& H. Špička: Mindfulness: Does it Influence Students’ Academic Success and Personal Wellbeing?

Table 1: Results of two opinion polls performed in February and March

\begin{tabular}{|c|c|c|c|c|c|c|c|}
\hline $\mathbf{N}$ & Statement & 1 & 2 & 3 & 4 & 5 & $\mathbf{0}$ \\
\hline \multirow[t]{2}{*}{1} & I pay attention to sensations. & 1 & 4 & 10 & 8 & 1 & 1 \\
\hline & & 3 & 3 & 6 & 12 & 1 & 0 \\
\hline \multirow[t]{2}{*}{2} & I watch my feelings without getting lost in them. & 0 & 3 & 13 & 7 & 1 & 1 \\
\hline & & 1 & 6 & 5 & 10 & 3 & 0 \\
\hline \multirow[t]{2}{*}{3} & I should not be feeling the way I am feeling. & 2 & 7 & 3 & 8 & 5 & 0 \\
\hline & & 9 & 8 & 6 & 0 & 2 & 0 \\
\hline \multirow[t]{2}{*}{4} & I believe my thoughts are abnormal or bad. & 7 & 7 & 6 & 3 & 1 & 1 \\
\hline & & 11 & 6 & 5 & 1 & 2 & $\overline{0}$ \\
\hline \multirow[t]{2}{*}{5} & I make judgments about my thoughts. & 6 & 5 & 6 & 5 & 3 & 0 \\
\hline & & 6 & 8 & 8 & 2 & 1 & 0 \\
\hline \multirow[t]{2}{*}{6} & I should not be thinking the way I am thinking. & 5 & 7 & 7 & 1 & 4 & 1 \\
\hline & & 9 & 11 & 3 & 1 & 1 & 0 \\
\hline \multirow[t]{2}{*}{7} & I judge myself as good or bad. & 2 & 1 & 8 & 7 & 5 & 2 \\
\hline & & 2 & 2 & 8 & 8 & 5 & 0 \\
\hline \multirow[t]{2}{*}{8} & I think my emotions are bad or inappropriate. & 7 & 8 & 7 & 1 & 2 & 0 \\
\hline & & 13 & 8 & 2 & 1 & 1 & $\mathrm{O}$ \\
\hline \multirow[t]{2}{*}{9} & $\begin{array}{l}\text { I notice how emotions affect thoughts and } \\
\text { behaviour. }\end{array}$ & 0 & 4 & 5 & 7 & 7 & 2 \\
\hline & & 2 & 3 & 3 & 13 & 4 & 0 \\
\hline \multirow[t]{2}{*}{10} & I disapprove of myself. & 7 & 6 & 7 & 4 & 1 & 0 \\
\hline & & 12 & 5 & 6 & 1 & 1 & 0 \\
\hline \multirow[t]{2}{*}{11} & I criticise myself for inappropriate emotions. & 8 & 5 & 4 & 6 & 2 & 0 \\
\hline & & 11 & 7 & 3 & 4 & 0 & 0 \\
\hline \multirow[t]{2}{*}{12} & I worry too much about the past and the future. & 0 & 5 & 3 & 6 & 7 & 4 \\
\hline & & 3 & 6 & 6 & 2 & 8 & 0 \\
\hline \multirow[t]{2}{*}{13} & $\begin{array}{l}\text { I perceive my emotions without reacting to } \\
\text { them. }\end{array}$ & 0 & 4 & 11 & 5 & 3 & 2 \\
\hline & & 2 & 1 & 7 & 8 & 7 & 0 \\
\hline \multirow[t]{2}{*}{14} & $\begin{array}{l}\text { I am good at finding words to describe my } \\
\text { feelings. }\end{array}$ & 2 & 4 & 6 & 11 & 1 & 1 \\
\hline & & 5 & 4 & 5 & 8 & 3 & 0 \\
\hline \multirow[t]{2}{*}{15} & I can easily put my thoughts into words. & 2 & 5 & 9 & 8 & 1 & 0 \\
\hline & & 5 & 5 & 8 & 5 & 2 & 0 \\
\hline \multirow[t]{2}{*}{16} & $\begin{array}{l}\text { When in trouble, I cannot find appropriate words } \\
\text { to explain it. }\end{array}$ & 1 & 7 & 10 & 5 & 2 & 0 \\
\hline & & 3 & 2 & 10 & 9 & 1 & 0 \\
\hline \multirow[t]{2}{*}{17} & $\begin{array}{l}\text { When getting into trouble, I want them solved } \\
\text { immediately. }\end{array}$ & 0 & 1 & 5 & 9 & 9 & 1 \\
\hline & & 1 & 4 & 4 & 9 & 6 & 1 \\
\hline
\end{tabular}


$1^{\text {ST }}$ INTERNATIONAL SCIENTIFIC CONFERENCE $\gg$ TEACHING METHOdS FOR ECONOMICS AND BUSINESS SCIENCES «

S. Sibila Lebe \& H. Špička: Mindfulness: Does it Influence Students' Academic Success and Personal Wellbeing?

\begin{tabular}{|l|l|r|r|r|r|r|r||}
\hline $\mathbf{N}$ & Statement & $\mathbf{1}$ & $\mathbf{2}$ & \multicolumn{1}{|c|}{$\mathbf{4}$} & \multicolumn{4}{|c}{} & $\mathbf{5}$ & $\mathbf{0}$ \\
\hline 18 & It's hard for me to find the words to describe. & 2 & 7 & 7 & 8 & 1 & 0 \\
\hline & & 3 & 4 & 7 & 3 & 8 & 0 \\
\hline 19 & I have trouble thinking of the right words. & 1 & 10 & 8 & 4 & 2 & 0 \\
\hline & & 3 & 4 & 8 & 7 & 3 & 0 \\
\hline 20 & $\begin{array}{l}\text { I cannot find the right words to describe } \\
\text { sensation. }\end{array}$ & 2 & 10 & 7 & 4 & 2 & 0 \\
\hline & & 3 & 5 & 6 & 7 & 4 & 0 \\
\hline 21 & When upset, I can find a way to put it into words. & 1 & 2 & 5 & 9 & 5 & 3 \\
\hline & & 6 & 3 & 6 & 5 & 5 & 0 \\
\hline 22 & Tendency is to put experiences into words. & 1 & 3 & 8 & 5 & 8 & 0 \\
\hline & & 4 & 2 & 7 & 8 & 3 & 1 \\
\hline 23 & I can usually describe how I feel at the moment. & 0 & 4 & 3 & 10 & 8 & 0 \\
\hline & & 2 & 6 & 5 & 9 & 2 & 1 \\
\hline 24 & I notice the sensations of my body moving. & 0 & 2 & 3 & 12 & 8 & 0 \\
\hline & & 2 & 5 & 5 & 6 & 7 & 0 \\
\hline 25 & I find it difficult to stay focused. & 1 & 7 & 10 & 5 & 2 & 0 \\
\hline & & 5 & 4 & 11 & 3 & 2 & 0 \\
\hline 26 & I do not pay attention to what I am doing. & 3 & 13 & 2 & 6 & 1 & 0 \\
\hline & & 2 & 9 & 10 & 2 & 2 & 0 \\
\hline 27 & I sometimes follow only half-hearted to the & 0 & 4 & 3 & 14 & 4 & 0 \\
& lecture, and do other things. & & & & & & \\
\hline & & 1 & 2 & 4 & 12 & 6 & 0 \\
\hline 28 & I just notice distressing things and let them go. & 0 & 4 & 10 & 8 & 3 & 0 \\
\hline & & 1 & 10 & 4 & 7 & 3 & 0 \\
\hline 29 & I am absent-minded while doing my work. & 1 & 11 & 6 & 3 & 4 & 0 \\
\hline & & 3 & 5 & 9 & 3 & 5 & 0 \\
\hline 30 & I often check my cell-phone during lectures. & 0 & 1 & 8 & 10 & 5 & 1 \\
\hline & & 2 & 2 & 3 & 9 & 9 & 0 \\
\hline 31 & I feel calm soon after distressing experiences. & 1 & 5 & 10 & 5 & 4 & 0 \\
\hline & 0 & 4 & 10 & 6 & 5 & 0 \\
\hline 32 & I rush through activities without being attentive. & 2 & 3 & 11 & 8 & 1 & 0 \\
\hline & 2 & 6 & 5 & 7 & 5 & 0 \\
\hline 33 & I do jobs or tasks automatically. & 1 & 5 & 7 & 8 & 4 & 0 \\
\hline & & 2 & 2 & 8 & 9 & 4 & 0 \\
\hline 34 & Notice distressing things without reacting. & 2 & 5 & 11 & 4 & 2 & 1 \\
\hline & & 3 & 5 & 12 & 4 & 1 & 0 \\
\hline 35 & Doing things without paying attention. & 1 & 4 & 11 & 7 & 2 & 0 \\
\hline & 3 & 4 & 9 & 7 & 2 & 0 \\
\hline 36 & I am aware of distressing thought or image. & 0 & 1 & 7 & 13 & 4 & 0 \\
\hline & & 1 & 5 & 12 & 2 & 0 \\
\hline
\end{tabular}


$1^{\text {ST }}$ InTERNATIONAL SCIENTIFIC CONFERENCE $\gg$ TEACHING METHOdS FOR ECONOMICS AND

BuSINESS SCIENCES«

S. Sibila Lebe \& H. Špička: Mindfulness: Does it Influence Students’ Academic Success and Personal Wellbeing?

\begin{tabular}{|c|c|c|c|c|c|c|c|}
\hline $\mathbf{N}$ & Statement & 1 & 2 & 3 & 4 & 5 & $\mathbf{0}$ \\
\hline \multirow[t]{2}{*}{37} & I can pause without immediately reacting. & 1 & 2 & 4 & 14 & 4 & 0 \\
\hline & & 2 & 3 & 7 & 8 & 5 & 0 \\
\hline \multirow[t]{2}{*}{38} & $\begin{array}{l}\text { I often eat snacks without even noticing that I am } \\
\text { eating. }\end{array}$ & 5 & 10 & 5 & 4 & 1 & 0 \\
\hline & & 8 & 8 & 2 & 6 & 1 & 0 \\
\hline \multirow[t]{2}{*}{39} & $\begin{array}{l}\text { I tend to use Internet services that are not part of } \\
\text { the pedagogical process. }\end{array}$ & 6 & 7 & 4 & 3 & 4 & 1 \\
\hline & & 1 & 0 & 7 & 11 & 6 & 0 \\
\hline \multirow[t]{2}{*}{40} & $\begin{array}{l}\text { When I face troubles I want to solve them } \\
\text { myself. }\end{array}$ & 0 & 4 & 7 & 8 & 6 & 0 \\
\hline & & 1 & 2 & 4 & 10 & 8 & 0 \\
\hline \multirow[t]{2}{*}{41} & I am "running on automatic". & 2 & 4 & 4 & 10 & 4 & 1 \\
\hline & & 7 & 4 & 7 & 5 & 2 & 0 \\
\hline \multirow[t]{2}{*}{42} & I stay alert to the sensations of water. & 4 & 3 & 6 & 9 & 3 & 0 \\
\hline & & 6 & 6 & 3 & 9 & 1 & 0 \\
\hline \multirow[t]{2}{*}{43} & I notice how foods and drinks affect thoughts. & 1 & 4 & 5 & 8 & 6 & 1 \\
\hline & & 6 & 4 & 5 & 8 & 2 & 0 \\
\hline \multirow[t]{2}{*}{44} & I am easily distracted. & 2 & 2 & 9 & 9 & 2 & 1 \\
\hline & & 4 & 5 & 6 & 8 & 2 & 0 \\
\hline \multirow[t]{2}{*}{45} & I am attentive to distractions in the room. & 0 & 2 & 6 & 12 & 5 & 0 \\
\hline & & 1 & 3 & 5 & 8 & 8 & 0 \\
\hline \multirow[t]{2}{*}{46} & I notice visual elements in art or nature. & 0 & 1 & 5 & 12 & 6 & 1 \\
\hline & & 1 & 3 & 5 & 10 & 6 & 0 \\
\hline \multirow[t]{2}{*}{47} & It is difficult for me to remain focused. & 2 & 4 & 10 & 6 & 3 & 0 \\
\hline & & 2 & 1 & 11 & 7 & 4 & 0 \\
\hline \multirow[t]{2}{*}{48} & I pay attention to sounds. & 0 & 1 & 3 & 14 & 6 & 1 \\
\hline & & 1 & 1 & 2 & 16 & 5 & 0 \\
\hline \multirow[t]{2}{*}{49} & My mind wanders off and I am easily distracted. & 0 & 6 & 6 & 8 & 4 & 1 \\
\hline & & 2 & 4 & 5 & 8 & 6 & 0 \\
\hline \multirow[t]{2}{*}{50} & I notice the smells and aromas of things & 0 & 2 & 5 & 15 & 2 & 1 \\
\hline & & 3 & 2 & 1 & 12 & 7 & 0 \\
\hline 51 & I took part in meditating regularly. & 1 & 1 & 4 & 10 & 9 & 0 \\
\hline 52 & $\begin{array}{l}\text { I inspired others for meditation (e.g. family } \\
\text { member, friend). }\end{array}$ & 9 & 8 & 4 & 3 & 1 & 0 \\
\hline 53 & When meditating I feel uncomfortable. & 3 & 7 & 5 & 4 & 6 & 0 \\
\hline 54 & Meditating during the lessons is loss of time. & 3 & 6 & 10 & 4 & 1 & 1 \\
\hline 55 & $\begin{array}{l}\text { Presence of other people is disturbing me while } \\
\text { meditating. }\end{array}$ & 9 & 6 & 5 & 4 & 1 & 0 \\
\hline$\overline{56}$ & $\begin{array}{l}\text { I do not like group meditation and would prefer } \\
\text { quitting it. }\end{array}$ & 5 & 5 & 9 & 3 & 2 & 1 \\
\hline
\end{tabular}


$1^{\text {ST }}$ INTERNATIONAL SCIENTIFIC CONFERENCE »TEACHING METHODS FOR ECONOMICS AND BUSINESS SCIENCES «

S. Sibila Lebe \& H. Špička: Mindfulness: Does it Influence Students' Academic Success and Personal Wellbeing?

\begin{tabular}{|l|l|r|r|r|r|r|r||}
\hline $\mathbf{N}$ & Statement & $\mathbf{1}$ & $\mathbf{2}$ & $\mathbf{3}$ & $\mathbf{4}$ & $\mathbf{5}$ & $\mathbf{0}$ \\
\hline 57 & $\begin{array}{l}\text { During this period I was meditating regularly at } \\
\text { home as well. }\end{array}$ & 14 & 5 & 2 & 4 & 0 & 0 \\
\hline 58 & $\begin{array}{l}\text { I shall continue meditating after the project at the } \\
\text { faculty is over. }\end{array}$ & 6 & 13 & 5 & 1 & 0 & 0 \\
\hline 59 & $\begin{array}{l}\text { I think meditation improved my condition in } \\
\text { general. }\end{array}$ & 7 & 5 & 7 & 4 & 1 & 0 \\
\hline 60 & $\begin{array}{l}\text { I think I can better concentrate since I am } \\
\text { meditating. }\end{array}$ & 6 & 9 & 5 & 3 & 1 & 1 \\
\hline 61 & $\begin{array}{l}\text { I can better remember the subject matter as } \\
\text { before meditation. }\end{array}$ & 7 & 9 & 6 & 2 & 0 & 1 \\
\hline 62 & Since I meditate, I feel calmer. & 6 & 7 & 5 & 5 & 1 & 1 \\
\hline 63 & Since I meditate, I became more self-confident. & 9 & 7 & 3 & 5 & 0 & 1 \\
\hline 64 & $\begin{array}{l}\text { I think I can communicate more easily with my } \\
\text { peers and professors due to meditation. }\end{array}$ & 7 & 8 & 6 & 2 & 1 & 1 \\
\hline 65 & $\begin{array}{l}\text { Due to meditation, I participate more actively in } \\
\text { the educational process. }\end{array}$ & 4 & 5 & 10 & 5 & 0 & 1 \\
\hline 66 & $\begin{array}{l}\text { Since I meditate, I notice I run into less conflict } \\
\text { situations with family members/peers. }\end{array}$ & 6 & 8 & 7 & 3 & 0 & 1 \\
\hline 67 & I think I have more vitality since I meditate. & 8 & 6 & 4 & 6 & 0 & 1 \\
\hline 68 & $\begin{array}{l}\text { My health condition has improved due to the } \\
\text { meditation. }\end{array}$ & 8 & 7 & 6 & 2 & 0 & 0 \\
\hline 69 & $\begin{array}{l}\text { Since I am meditating, I became more } \\
\text { emotionally balanced. }\end{array}$ & 9 & 4 & 6 & 5 & 0 & 1 \\
\hline 70 & Since I meditate, I can sleep better. & 9 & 6 & 5 & 5 & 0 & 0 \\
\hline 71 & $\begin{array}{l}\text { I think I became a better human being since I } \\
\text { meditate. }\end{array}$ & 6 & 6 & 2 & 1 & 2 \\
\hline
\end{tabular}

The biggest shifts in the table between the first opinion poll and the second one are coloured. Most of the highlighted values demonstrate a positive personal development of the participating population: they have developed a noticeably higher self-esteem and have improved their attitude towards themselves (statements 3, 4, 6, 8 and 10, being the most depressive statements in the questionnaire).

What the teachers are glad about are the improved scores regarding the students' being centred (focussed) as well as regarding their active participation in the course: especially some second semester students (the youngest ones) reacted somewhat childish to the first experiencing of meditating. They laughed, jiggled (found it obviously funny) or showed unrespectable behaviour towards the teacher and the meditating peers by talking with their neighbours, checking their mobile phones, or working on their tablets/computers (found it boring). Such behaviour decreased with the ongoing process. 
S. Sibila Lebe \& H. Špička: Mindfulness: Does it Influence Students’ Academic Success and Personal Wellbeing?

We have to consider that this is a still an ongoing process and that some results will most probably change considerably by the end of the project (semester). If the teachers have not noticed an 'overwhelming enthusiasm' about meditating at the beginning - the students were surprised and seemed to be either a bit embarrassed, bored or amused - so things have changed soon, and are still changing. Most of the students who are experiencing meditation regularly got used to it and seem to enjoy it increasingly. Students who (still?) do not wish to participate (one student in each $4^{\text {th }}$ and $6^{\text {th }}$ semester) seat quietly during the 10 minutes of meditation, allowing their colleagues to contemplate. The atmosphere in both courses is positive, and the students calm considerably down during the mediation. The teachers' experience regarding the students' eagerness to cooperate is without any doubt much higher than it was without the meditation.

\section{Conclusion}

The aim of the paper was to discover whether - and if yes, to what extent - practicing meditation as the best known mindfulness practice increases the wellbeing of students and their attentiveness - in other words: does it influence students' academic success?

Although this paper is presenting preliminary results of this still lasting project, several positive outcomes can clearly be stated already in this early stage. The most important ones are regarding the self-esteem of the participating students, as well as their ability to concentrate. The opinion poll results are confirmed by the observations that the teachers could gather in this period: the students are noticeably more eager to discuss the matter, are much more centred, and also seem to be more interested in the matter than - of course on average - the generations before them.

The authors think that even these preliminary results might be interesting for other professors attending this conference - perhaps even interesting enough to encourage further pedagogic staff to perform a similar project.

\section{References}

Bishop, S. R., Lau, M., Shapiro, S., Carlson, L., Anderson, N. D., Carmody, J., Devins, G. (2004). Mindfulness: A proposed operational definition. Clinical Psychology: Science and Practice, 11(3), 230-241. Retrieved from http://www.personal.kent.edu/ dfresco/mindfulness/Bishop_et_al.pdf

Brown, K. W. \& Ryan, R. M. (2003). The benefits of being present: Mindfulness and its role in psychological well-being. Journal of Personality and Social Psychology, 84, 22-848.

Carlson, L. E. \& Brown, K. W. (2005).Validation of the mindful attention awareness scale in a cancer population. Journal of Psychosomatic Research, 58(1), 29-33.

Chiesa, A., 2012. The difficulty of defining mindfulness: Current thought and critical issues. Mindfulness, 4(3), 255-268. doi:10.1007/s12671-012-0123-4

Germer, C. (2004). What is mindfulness. Insight Journal, 22, 24-29. 

AND BUSINESS SCIENCES«

S. Sibila Lebe \& H. Špička: Mindfulness: Does it Influence Students’ Academic Success and Personal Wellbeing?

Medvedev, O. N., Siegert, R. J., Kersten, P. \& Krägeloh, C. U. (2017). Improving the precision of the five facet mindfulness questionnaire using a rasch approach. New York: Springer Science+Business Media.

Orel, M. (Ed.). (2016). International Conference MINDfulness 2016, »Be Mindful, Teach Mindfully, Teach Mindfulness" (Mednarodna konferenca MINDfulness 2016»Bodite čuječni, poučujte čuječno in učite čuječnost «). Polhov Gradec: EDUvision.

Schwind, J. K., McCay, E., Beanlands, H., Martin, L. S., Martin, J., \& Binder, M. (2017). Mindfulness practice as a teaching-learning strategy in higher education: A qualitative exploratory pilot study. Nurse Education Today, 50, 92-96.

Siegel, R. D., Germer, C. K. \& Olendzki, A. (2008). Mindfulness: What is it? Where did it come from?. In F. Didonna (Ed.), Clinical handbook of mindfulness (pp. 17-35). New York: Springer-Verlag.Retrieved from http://www.mindfulselfcompassion.org/articles/nicamb_mindfulness.pdf

Wang, Y. \& Liu, C. (2016). Cultivate mindfulness: A case study of mindful learning in an English as a foreign language classroom. The IAFOR Journal of Education, 4(2), 141155.

Zupančič, D. (2015, November 12). MF Helpline - Vodena meditacija čuječnosti (Mindfulness) [Video file]. Retrieved from https://www.youtube.com/watch?v=Xklj6HXxGik 


\title{
Contemporary Dilemmas in Teaching Economics and Business Sciences
}

\author{
FRANJO MLINARIČ
}

\begin{abstract}
Teaching economics and/or business sciences is probably one of the most challenging occupations. The multidisciplinary nature of economics was best described by Keynes (1924): "The master-economist must be mathematician, historian, statesman, philosopher - in some degree". Some similarly diverse creature might be demanded to master and teach business sciences. Fortunately, teachers are only humans, trying to find the right balance between student aspirations, labour market expectations and their own abilities. Teaching such abstract and predominantly ambiguous concepts confronts us with a balancing act between theory and practice, especially with the younger audience lacking experience. At the same time, it is still unclear how to respond to potential employer's expectations who seem to prefer (like Keynes, 1931) “... humble, competent people on a level with dentists capable of solving pressing problems within their limited areas of expertise". Education in general has various long-term spill-over effects, hence it is hard to establish precisely which knowledge, skills and competences will contribute most to an individual's happiness during her lifetime. Therefore, we might follow Keynes's ambition by promoting interdisciplinary knowledge and teamwork, encourage scepticism and demonstrate the benefits of ethical and humble behaviour.
\end{abstract}

Keywords: • teaching economics and business knowledge $\bullet$ hard and soft skills $\bullet$ experience $\bullet$ grading dilemma $\bullet$ work ethics $\bullet$

CORRESPONDENCE AdDress: Franjo Mlinarič, Ph.D., Assistant Professor, University of Maribor, Faculty of Economics and Business, Razlagova 14, 2000 Maribor, Slovenia, e-mail: franjo.mlinaric@um.si. 
$1^{\text {ST }}$ InTERnATIONAL SCIENTIFIC CONFERENCE $»$ Teaching METHOdS FOR ECONOMICS AND BUSINESS SCIENCES «

F. Mlinarič: Contemporary Dilemmas in Teaching Economics and Business Sciences

\section{$1 \quad$ Introduction}

The main purpose of any branch of science is creating and disseminating (i.e. teaching) general knowledge, which can be used repeatedly. Thus, natural sciences have a relatively easy task due to the fact that their matter of research is stable and their well-founded tower of knowledge is higher with every successfully executed empirical test. Understanding and teaching economics and business sciences is inherently ambiguous task due to the ever-changing relations between human decision makers and consequent interpretations by various schools of economic thought or best practice promoters.

Following the Europe 2020 Strategy, adopted by the European Council in 2010, we find tertiary education attainment of the population aged 30-34 as one of the headline indicators, which should be above $40 \%$ by 2020 . On the other hand, the data show an increasing unemployment rate even for young people with tertiary education, although it is still much lower in comparison with lower levels of education. Hence, it has become obvious that quantitative goal setting in education contributes mainly to resource squandering and frustrated degree holders.

According to 2014 findings (EC, 2014) “92\% of employers are looking for transversal skills such as openness to and curiosity about new challenges, problem-solving and decision-making skills, confidence, tolerance towards other personal values and behaviours." Top 5 most important skills for recruitment from EU employers' perspective are: team work skills, planning and organisational skills, adaptive capabilities, communication skills, analytical and problem-solving skills (EC, 2016).

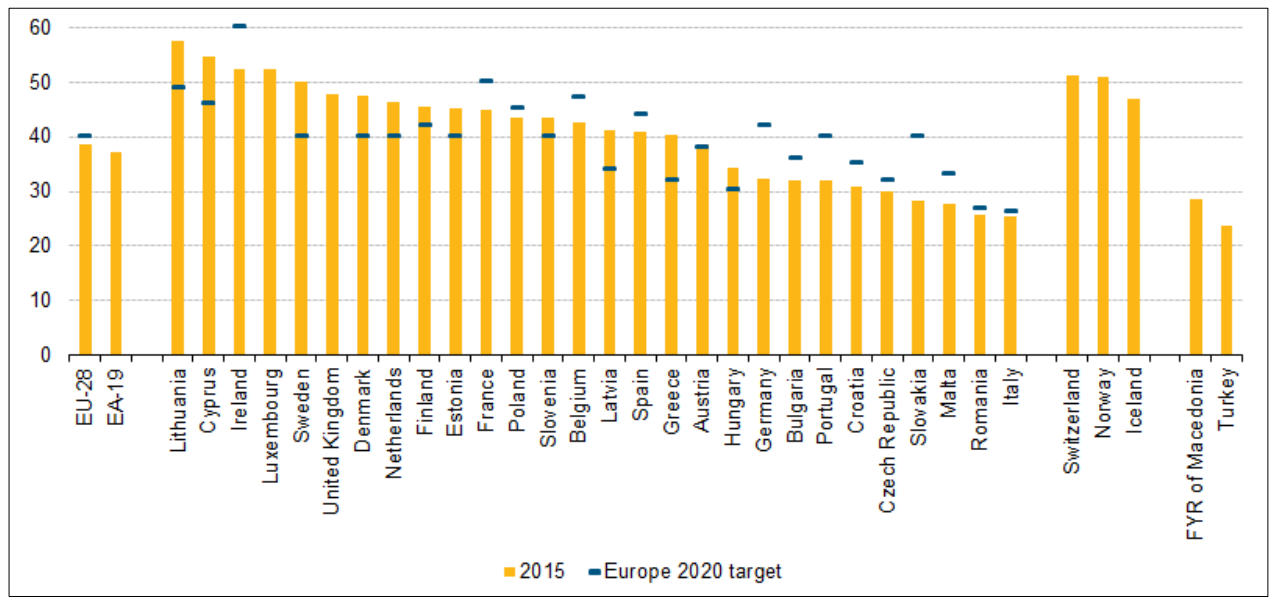

Figure 1: Population aged 30-34 with tertiary education attainment (ISCED 5-8), by country (EUROSTAT, 2017)

Our society and especially individuals should accept the fact that education is actually a long-term investment and as such, it should be properly analysed by each potential student 
(investor) before making a decision. Inherent risks in the education market are relatively high due to extreme information asymmetry. This is the key reason why the state should impose effective regulatory measures for quality control and enhance competition between educators at the same time.

Unfortunately, educators in both natural and social sciences are habitually isolated from the real expectations of the labour market. According to Mourshed et al. (2014), education providers demonstrate high overconfidence levels (Figure 2) when asked: "Do you agree that your students are well prepared for the job market?". Thus, we run the risk of overspending on national goal of increased tertiary education and contributing to structural unemployment.

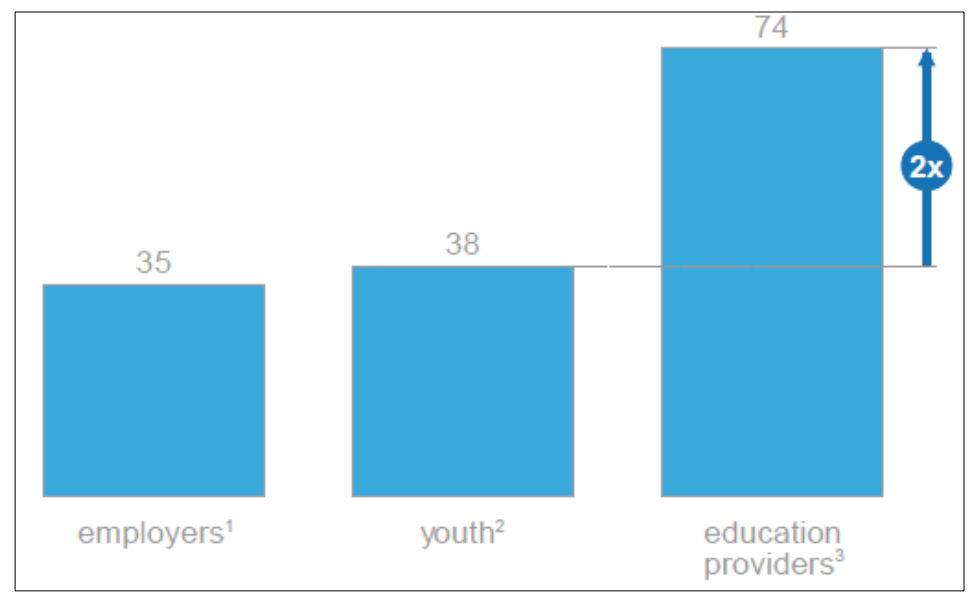

Figure 2: E2E gap - education providers' overconfidence (Mourshed et al., 2014, p. 10)

Nowadays educators should concentrate on the whole E2E (Education-to-Employment) path in order to understand the challenges which young people have to master on their journey. Therefore, a 'seamless care' concept should be built around the student and not around the educator. Consolidating diverse expectations towards education, we should not simply follow the employers uncritically, but at the same time, the upper figure reminds us that a productive coalition between employees, youth and education providers is urgently needed.

\section{The grading dilemma}

Great management thinker P. Drucker expressed it bluntly: "you can't manage what you can't measure", but at the same time we should also heed A. Einstein's warning: "Not everything that counts can be counted...".

Following the trends in international education standards, we get the impression that Drucker's idea is gaining momentum. From national education strategies to recognised 
$1^{\text {ST }}$ INTERNATIONAL SCIENTIFIC CONFERENCE $»$ TEACHING MeThods FOR ECONOMICS AND BUSINESS SCIENCES«

F. Mlinarič: Contemporary Dilemmas in Teaching Economics and Business Sciences

accreditation standards, we perceive increased awareness that relevant learning outcomes can be efficiently planned, developed and achieved if they are:

- cooperatively established and monitored by key stakeholders (students, employers and educators); and

- properly measured in the assessment processes.

According to our experience, the whole education system (including tertiary level) is still concentrated on teaching hard skills like (local or foreign) language proficiency, basic math skills, computer literacy, etc. These skills are also relatively easy to measure in the assessment process, because they are easy to check and justify.

Our informal hypothesis could be confirmed on a sample of $8 \mathrm{EU}$ education systems. The following figures are based on the McKinsey study (Mourshed et al., 2014) which asked employers to rate entry-level employees hired in the past year. Surveyed employers first rated the importance of key skills for the effective work of newcomers, and later they had to rate for each skill how competent, on average, the young employees were.

Using the survey results, we assume a direct link between low skill gaps for those hard skills, which are a clear priority in the education system and are easy to assess. On primary education level this might be less of a problem, because subjects have a narrower scope like math, local language etc. Regardless of this narrowness, even in the first years of primary school, teachers have to assess soft skills like creativity, spoken communication, teamwork etc. However, when the subjects became more complex with years, it becomes ever harder to produce a final grade, which would fairly and honestly reflect a comparative measure of adopted hard and soft skills.

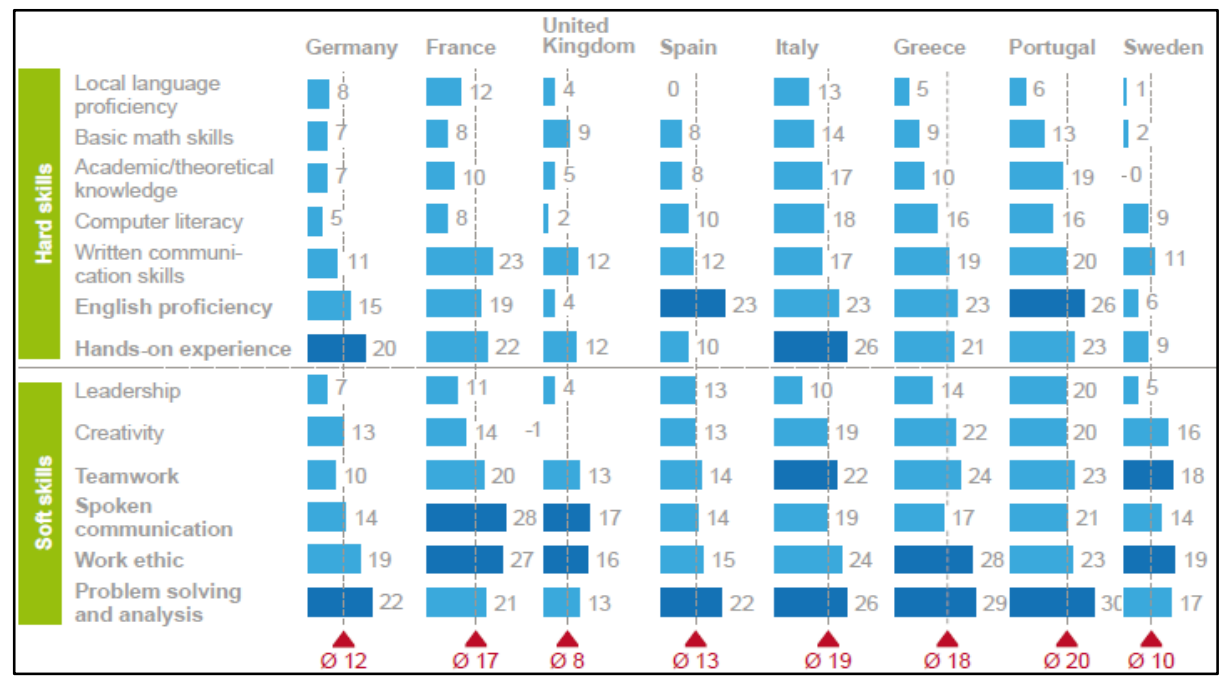

Figure 3: Skill gaps quantified by employers across Europe (Mourshed et al., 2014, p. 45) 
F. Mlinarič: Contemporary Dilemmas in Teaching Economics and Business Sciences

EU data demonstrate relatively low gaps for basic hard skills in most developed EU countries and the UK. Nevertheless, even such skills are at risk if national education systems lack proper teaching methods and final scrutiny (e.g. Italy and Portugal). Interestingly, most presented countries indicate a relatively high gap in written communication skills, which can be associated with a demise in reading habits.

Appropriate assessment, which is predominantly expressed with a number, becomes increasingly challenging with complex subjects (and their learning outcomes) at the tertiary level of education. With every study year, the students are required to conquer ever-bigger fragments of Bloom's pyramid of learning. Unfortunately, the assessment tools are still mainly concentrated on basic hard skills (like academic/theoretical knowledge, basic math skills and local language proficiency).

In consequence, our grading (measuring) systems mainly pretend to measure the aggregate level of achieved skills, since easily measured hard skills needed for the lower levels of Bloom's pyramid still prevail. Finally, the whole grading system is biased towards rule-obeying fact memorisers and shows a grading inflation for decades. At the same time, it is a misguiding signal of skill adoption for students as well as for teachers and useless information for human resource departments.

Trying to squeeze different aspects of hard and soft skills into a cumulative measure (called grade) might be 'mission impossible' for 3 main reasons:

- criteria clarity (incomparable skills, arbitrary weights),

- lack of assessment support system resources, and

- administrative rules.

Thus, the whole assessment process often succumbs to fact checking activity. It is easier to prepare, verify, set the grade and defend it with unsatisfied students, especially when considering the assigned time and other resources.

'Grade inflation' is a well-known phenomenon even with Ivy League Universities. Latest data show an increase in average grade by around 1/3 since 1963. Thus, the most commonly awarded grade is an A (The Economist, 2014). The problem might be even more exaggerated with elective courses, which have to attract the minimum number of students to be offered. Finally, there is a risk that skewed incentives for university financing and teachers tenure lead to a system of rewarding those students who are best in finding the path of least efforts through the education system.

\section{$3 \quad$ Effective teaching}

Students represent a very heterogeneous sample of individuals with various motivations, social backgrounds, learning styles, accumulated knowledge, skills etc. Consequently, each of them would require a tailored teaching approach to achieve the highest retention rates. The model of effective teaching obviously has several variables. Only consistent 
$1^{\text {ST }}$ INTERNATIONAL SCIENTIFIC CONFERENCE $\gg$ TEACHING MethodS FOR ECONOMicS AND BUSINESS SCIENCES«

F. Mlinarič: Contemporary Dilemmas in Teaching Economics and Business Sciences

following of best practice and own innovations can help us to improve. Therefore, the minimum checklist for every educator should follow the four fundamental questions established by Anderson et al. (2001):

- What is important for students (the learning question)?

- How to plan and deliver instruction (the instruction question)?

- How to select or design assessment instruments and procedures (the assessment question)?

- How to align objectives, instruction and assessment (the alignment question)?

One of the most well-known intuitive models for effective learning was presented by Edgar Dale in 1946 and was called 'Cone of Experience' or 'Cone of Learning' (left triangle). It is not based on scientific research, but various users started to add round values for assumed retention rates. The cone of learning demonstrates the importance of various teaching methods in order to stimulate student's commitment.

Interestingly, the cone of learning corresponds with Bloom's revised learning pyramid. Combined approaches signal a necessary continuum of learning methods, which contribute to the size of different levels of Bloom's skills pyramid. It functions as a positive feedback loop which re-enforces the never ending learning process.

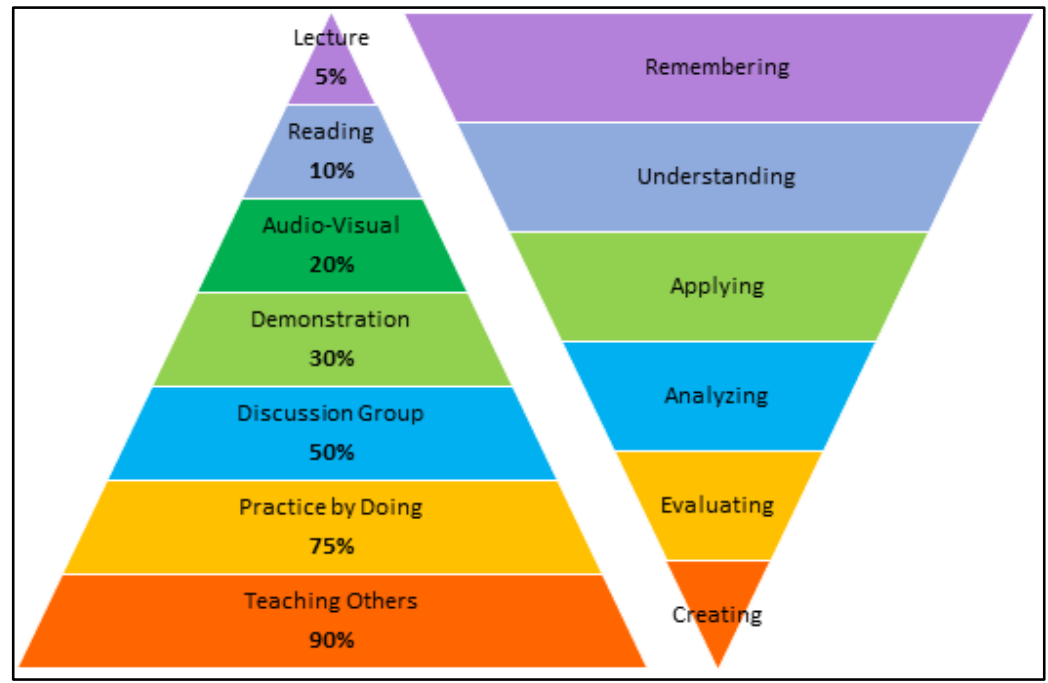

Figure 4: Cone of learning and Bloom's revised taxonomy (Lalley et al., 2007, p. 45)

Teaching is a complex process based on the knowledge dimension and cognitive process dimension. The journey to the top of this steep stairway depends on in-school and out-ofschool activities. Each of the coloured blocks in the pyramid represents a learning goal, which needs to be conquered before moving to the next level. There are almost no shortcuts on the way to the top, since the whole construction is as strong as its fundaments. 
F. Mlinarič: Contemporary Dilemmas in Teaching Economics and Business Sciences

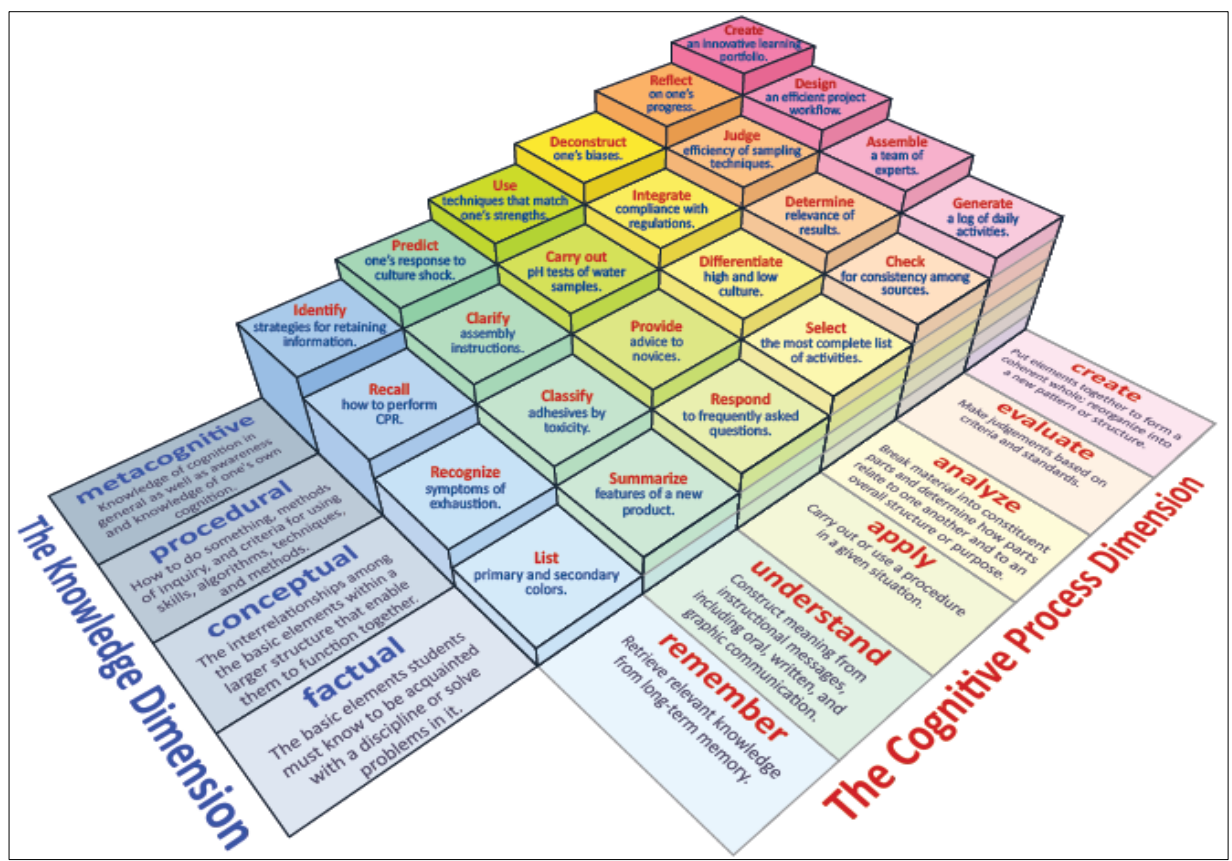

Figure 5: Learning objectives (Heer. R., 2012)

Higher level of education is still tough, long-term and risky endeavour and this is one of the reasons why many educational institutions promote the Latin saying 'per aspera ad astra'. However, it enables people to gain handsomely if they are able to mitigate those risks, otherwise great disappointment and loss of time as well as money in inevitable.

A passionate, competent, emphatic and well-organised teacher is one part of the effective teaching puzzle. On the other side, we have students with their motivations, capabilities, interests etc. When teachers excel in their part, students have to follow with their obligations. Although, we observe a worrying trend where academic teachers are under ever more pressure for their teaching, research and professional results (within the same resources), whereas the students receive ever more relaxed requirements (56\% for a positive grade - as lowered from $60 \%$, no homework, no obligation to participate, etc.).

The greatest challenge in teaching economics and business sciences nowadays is to commit the students to a very old and simple idea: Practice makes perfect. We shall call it the axiom of success, which is comprehensively presented in Willingham (2009) for a sample of violin students. Figure 6 actually indicates 'a ten year rule' which is needed to achieve the best performance on a violin or any other professional activity. The main differentiator between different levels of success seems to be the amount of accumulated hours of practice. However, we could also describe it with a quote from T. A. Edison: "Genius is 1 percent inspiration, 99 percent perspiration." 
$1^{\text {ST }}$ InTERnational SCIENTIFIC CONFERENCE $\gg$ TEACHING METHOdS FOR ECONOMICS AND BUSINESS SCIENCES «

F. Mlinarič: Contemporary Dilemmas in Teaching Economics and Business Sciences

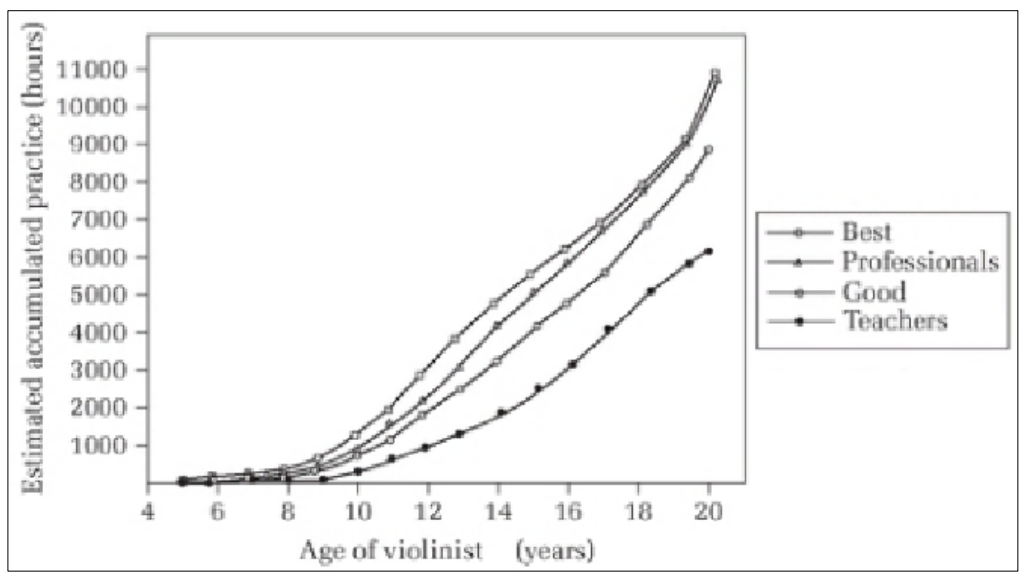

Figure 6: Total amount of hours for violinists accumulated over the years (Willingham, 2009)

\section{Conclusion}

Standardising acquired knowledge and adopted skills in social sciences in order to evaluate them on common grounds will probably remain an unreachable goal. Nevertheless, we need more collaborative and clearly defined course objectives as well as more or less clearly measurable learning outcomes. They shall benefit all three interest groups and the society in general, since: i) the students could make more informed decisions about their specialisation and electives, as well as tailor made feedback on their skills; ii) the schools could optimise their portfolio of programs and courses towards the long-term market needs; iii) the employers would receive a well-structured skills profile of potential employees.

Teaching economics and business sciences will most probably remain a challenge for the next generations while it has to become more open: i) for innovation in the field of teaching methods, ii) for more cooperation between stakeholders, and iii) for a complex grading system, which supports an efficient carrier development based on Bloom's revised taxonomy.

\section{References}

Anderson, L. W., Krathwohl, D.R., Airasian, P. W., Cruikshank, K. A., Mayer, R. E., Pintrich, P. R., Raths, J., \& Wittrock, M. C. (2001). A taxonomy for learning, teaching, and assessing: A revision of Bloom's taxonomy of educational objectives. New York: Longman.

EC-European Commission. (2010). Europe 2020. A strategy for smart, sustainable and inclusive growth. Brussels: European Commission. Retrieved from http://ec.europa.eu/eu2020/pdf/COMPLET\%20EN\%20BARROSO\%20\%20\%20007\%20$\% 20$ Europe $\% 202020 \% 20-\% 20 \mathrm{EN} \% 20$ version.pdf 
F. Mlinarič: Contemporary Dilemmas in Teaching Economics and Business Sciences

EC-European Commission. (2014). The Erasmus impact study. Luxembourg: Publication Office of the European Union. Retrieved from

http://ec.europa.eu/dgs/education_culture/repository/education/library/study/2014/erasmu s-impact_en.pdf

EC-European Commission. (2015). EU youth report. Luxembourg: Publication Office of the European Union. Retrieved from http://ec.europa.eu/assets/eac/youth/library/reports/youth-report-2015_en.pdf

EC-European Commission. (2016). The Erasmus impact study - Regional analysis. Luxembourg: Publication Office of the European Union. Retrieved from http://ec.europa.eu/dgs/education_culture/repository/education/library/study/2016/erasmu s-impact_en.pdf

EURYDICE. (2011). Teaching reading in Europe: Contexts, policies and practice. Brussles: Education, Audiovisual and Culture Executive Agency. Retrieved from http://eacea.ec.europa.eu/education/eurydice/documents/thematic_reports/130EN.pdf

Keynes, J. M. (1924). Alfred Marshall, 1842-1924. The Economic Journal 34(135), 311-372.

Keynes, J. M. (1931). Essays in persuasion. London: Macmillan. Retrieved from https://www.gutenberg.ca/ebooks/keynes-essaysinpersuasion/keynes-essaysinpersuasion00-h.html

Lalley, J. P., \& Miller, R. H. (2007). The learning pyramid: Does it point teachers in the right direction?. Education, 128(1), 64-79.

Mourshed, M., Patel, J., \& Suder, K. (2014). Education to employment: Getting Europe's youth into work. Berlin: McKinsey Center for Government. Retrieved from https://www.mckinsey.de/files/a4e2e_2014.pdf

OECD. (2016). PISA 2015 results in focus. Paris: OECD. Retrieved from https://www.oecd.org/pisa/pisa-2015-results-in-focus.pdf

The economics of university grading: What Ivies can learn from Wellesley. (2014, August 11)

The Economist. Retrieved from

http://www.economist.com/blogs/freeexchange/2014/08/economics-universitygrading? fsrc=scn/tw/te/bl/ed/whattheiviescanlearn

Willingham, D. T. (2010). Why don't students like school? A cognitive scientist answers questions about how the mind works and what it means for the classroom. San Francisco, CA: John Wiley \& Sons. 
$62 \mid 1^{\text {ST }}$ International SCIENTIFiC CONFERENCE $»$ Teaching Methods For ECONOMics AND BUSINESS SCIENCES« 


\title{
Exam Wrappers: Reflecting on the Study Skills of Freshmen in MIS
}

\author{
BIRGIT OBERER \& ALPTEKIN ERKOLLAR
}

\begin{abstract}
Exam wrappers are a tool geared toward helping students reflect on their studying approach. After an exam, students reflect on their exam preparation, their performance on the exam, and their preparation for future exams. The purpose of this reflection activity is for the students to evaluate what they know, take ownership of what they know and don't know, and examine their exam performance. In this study, exam wrapper reflection analysis was applied for freshmen in management information systems at a higher education institution. This reflection method was used for two courses offered to MIS students in their first year; exam wrappers were provided for two exams for each course. The results of the study revealed that exam wrappers could make exams worth more than the grade, transforming how instructors and students use exams as a tool for learning, thereby directly influencing instructors' and students' behavior.
\end{abstract}

Keywords: • text wrapper • higher education • business management • learning $\bullet$ reflection $\bullet$

Correspondence Addresses: Birgit Oberer, Ph.D., Associate Professor, Sakarya University, Sakarya Business School, Esentepe Campus, 54187 Serdivan, 54000 Sakarya, Turkey, e-mail: oberer@sakarya.edu.tr. Alptekin Erkollar, Ph.D., Professor, Sakarya University, Sakarya Business School, Esentepe Campus, Esentepe Campus, 54187 Serdivan, 54000 Sakarya, Turkey, e-mail: erkollar@sakarya.edu.tr. 


\section{Introduction}

Teaching students how to manage a qualitative self-assessment of their knowledge and learning behavior may lead to positive, long-lasting effects on student learning. These skills and abilities can be developed by allocating class time to teach students alternative study strategies or by giving assignments that force students to practice these skills outside of class. One method to embed metacognitive training and education into a course is by utilizing course exams as an opportunity for students to practice metacognition itself and apply their new knowledge on their individual learning processes. Exam wrappers and their effect on student learning have been explored in various disciplines. They are one method to be used for analyzing students' metacognitive abilities. According to Lovett (2013), exam wrappers are based on the following questions:

$\checkmark$ How did a student prepare for the exam?

$\checkmark$ What kind of errors did the student make on the exam?

$\checkmark$ What could a student do differently next time?

The overall purpose of this classroom research project is to evaluate the impact of exam wrappers in two introductory Management Information Systems courses, on students' study behavior and their perception of this new metacognitive training and evaluation tool.

\section{Literature review}

\subsection{Metacognition}

Metacognition refers to the processes used to plan, design, monitor, and assess one's understanding, ability for critical review, and performance. It includes a critical awareness component of one's (1) thinking and learning and (2) oneself as a thinker and learner (Chick et al., 2009; Halpern, 1996; Garner, 1990). Metacognition, or the ability to control one's cognitive processes (self-regulation), has been linked to intelligence (Scheid, 1993; Sternberg, 1986). Sternberg (1984) refers to these executive processes as 'metacomponents' in his theory of intelligence. Metacognitive practices increase students' abilities to transfer or adapt their learning to new contexts and tasks; they also think about the tasks and contexts of different learning situations and themselves as learners in these different contexts (Silver, 2013; Kegan \& Lahey, 2009; Livingston, 1996). Pintrich (2002) asserts that 'students who know about the different kinds of strategies for learning, thinking, and problem solving will be more likely to use them' and notes that the students must 'know about' these strategies, not just practice them. There are two studies (Lovett et al., 2013; Winkelmes, 2013) focusing on metacognition, the process of 'thinking about your thinking' as a process to improve learning. The studies demonstrate how reflection and metacognition can be used to improve students' learning habits and exam performance by focusing on critical review and self-based learning control flow. Metacognitive approaches help students become aware of their strengths and weaknesses as learners, test-takers, and group members. A key element is recognizing 
B. Oberer \& A.Erkollar: Exam Wrappers: Reflecting on the Study Skills of Freshmen in

the limit of one's knowledge and figuring out how to expand that knowledge. Those students who know their strengths and weaknesses in these areas will be more likely to 'actively monitor their learning strategies and resources and assess their readiness for particular tasks and performances' (Ramirez \& Beilock, 2011; Bransford et al., 2000; Roberts \& Erdos, 1993).

\subsection{The role of reflection in metacognition}

The concept of 'reflective thinking' was introduced by John Dewey in 1910 in his book 'How We Think' in order to represent active, persistent, and careful consideration of any belief or supposed form of knowledge in the light of the grounds that support it and the further conclusion to which it tends (Dewey, 1933). Reflection here involves the learner as the object of reflection. Schön (1987) states that the reflective thinker is aware of their knowledge and lack of knowledge and recognizes that there may not be only a single correct solution to a given problem or interpretation of a situation. Self-reflection is related to metacognition. It provides not only a better understanding of what a student knows, but also a way of improving metacognitive strategies because the learner can examine how they performed a specific learning task. Zimmerman (2000) argues that self-reflection has a central role in achieving self-regulation in learning. When a learner reflects on an action that they have just performed, they are consciously revisiting the information. Along with the advantage of re-reading, if the student is engaged in an activity that requires them to restructure or explain their thinking, it is expected to result in better learning.

\section{$3 \quad$ Exam wrapper reflection analysis}

One teaching goal at higher education institutions is to help empower students for becoming self-directed learners, organizing and structuring their individual learning processes on their own. One method used in this effort is wrappers. A wrapper is a short form that students complete along with an exam, assignment, or assessment focusing not on the content but rather on the process of learning as well. Lovett et al. (2013) created exam wrappers, providing students with the ability to reflect, compare, and adjust their learning habits and learning strategies. They showed that students could make changes in their learning strategies based on the exam wrapper outcome and tend to be more successful when regularly used exam wrapper analysis for evaluating their study behavior.

\subsection{Guidelines for using wrappers}

Wrappers are a tool given to students so that they are able to evaluate how they were prepared for an exam, assessment, or assignment, for what went well, what did not, and how they might have to adjust their studying behavior. 
$1^{\text {ST }}$ INTERNATIONAL SCIENTIFIC CONFERENCE »TEACHING METHODS FOR ECONOMICS AND BUSINESS SCIENCES «

Oberer \& A.Erkollar: Exam Wrappers: Reflecting on the Study Skills of Freshmen in MIS

Therefore:

$\checkmark$ wrappers should be used in class frequently;

$\checkmark$ a flexible wrapper template should be used so that it can be adjusted and individualized for any kind of exam, assessment, or assignment;

$\checkmark$ wrappers can be handed out to students (1) one dimensional: when the exam has been written/assignment been handed in and has been graded to evaluate study performance reactively (AFTER - REACTIVE) or (2) two dimensional: one when the exam/assignment has been written and once more when the exam has been graded (BEFORE and AFTER - PROACTIVE.

The exam wrapper process (Gezer-Templeton, 2017; Lovett et al., 2013) can be summarized in the following steps:

$\checkmark$ Wrappers are handed out when exams/assignments are returned or after they are written and once more when they are returned (for getting a postevaluation).

$\checkmark$ Students are asked to fill out the form in less than 10 minutes inside or, if necessary, outside of class.

$\checkmark$ Students are not graded based on the wrapper content, but they may receive points for returning the wrapper (optional).

$\checkmark$ The instructor collects the forms and reads through them to find some general themes. Potential adjustments to the course may be made as a result of the findings.

$\checkmark$ Before another exam or assignment, the instructor may discuss the wrapper analysis results with students, basically to get in touch with them regarding how to adjust their learning strategies when preparing for the upcoming exam.

$\checkmark$ Students may discuss and compare their learning strategies in small groups.

$\checkmark$ A wrapper may be used several times during a course.

4 The study: Exam wrapper reflection analysis applied for Management Information Systems courses

\subsection{Objectives}

The objectives guiding this study were for:

(1) examining students' metacognitive skills and abilities, such as goal setting and self-assessment, and

(2) evaluating the correlation between study behaviors and student performance. 
$1^{\text {ST }}$ InTERNATIONAL SCIENTIFIC CONFERENCE $\gg$ TEACHING METHOdS FOR ECONOMICS AND

B. Oberer \& A.Erkollar: Exam Wrappers: Reflecting on the Study Skills of Freshmen in

MIS

\subsection{Target group and target courses}

The target group for the exam wrapper analysis conducted in this study is first-year students of a management information systems program at the bachelor's level at a higher education institution in Turkey.

The exam wrapper reflection analysis was applied for the following courses:

(1) MIS101 introduction to management information systems (to be taken in the first semester)*

(2) MIS 102 introduction to marketing (scheduled for the second semester).**

* 36 students, all of whom contributed to both exam wrappers

** 54 students, 53 of whom contributed to both exam wrappers

For MIS101 introduction to management information systems, students had to write two exams (midterm and final) and had to do weekly assignments. The exam wrapper reflection analysis was applied for both exams. For MIS102 introduction to marketing, students had to complete two exams (midterm and final) and had to do four assignments. The exam wrapper reflection analysis was applied for both exams.

\subsection{Exam wrapper reflection analysis}

This reflection method was used for two courses offered to MIS students in their first year; exam wrappers were provided for two exams for each course. After exams, students reflected on their exam preparation, performance on the exam, their expectations on future exams, and how they plan to change the way they prepare for exams, based on their exam wrapper results. After taking exams, the students reflected on the exam content and their experience taking the exam by using exam wrappers handed over to them before the exam and when they received feedback on their exam results. The purpose of this activity was for students to (1) evaluate what they know, and (2) examine their exam performance. After each exam, students reflected on their experience taking the exam by answering a series of questions, such as:

(1.1) Estimate the time studying for the exam;

(1.2) Estimate the percentage of preparation time spending on activities, such as setting targets for studying, writing notes, studying lecture notes, listening to audio lecture notes, and watching lecture videos).

The instructor collected the exam wrappers and had a look for emerging themes to be addressed. After the instructor graded the exams and the students saw their results, the instructor gave them their exam wrappers again and the students had to reflect on the answers that they gave directly after writing the exam and before getting the instructor's feedback; and answering the following questions: 
(2.1) Estimate the percentage of points lost due to different reasons, such as the application of wrong concepts, non-studying relevant topics, mixing up theories, or not reading exam instructions carefully).

(2.2) Identifying four to five things that students plan to do differently when preparing for the next exam.

(2.3) If working in groups when preparing for the exam: what could the learning group do (differently) to support students' learning activities?

(2.4) What could the instructor do (differently) for supporting students' learning activities and exam preparation?

On the exam wrapper sheets, there are two columns to be filled: (1) directly after the exam, (2) after receiving the exam results. For (1) students got the same questions and had to reflect their initial answers when receiving the exam results. In case the answers before and after the exam grading differed in a third column, the students could fill in a comment on why, according to their opinion, the answers differed. Section 2 has to be filled in after getting the grading results; reflecting where students lost points, what they would do differently in the future, and (if available) how the learning group and instructor could support them on preparing for an upcoming exam. In the section of the exam wrapper, they could formulate their lessons learned and summarize again how they plan to prepare for upcoming exams. All of the exam wrappers start with the following explanation:

'As with the first exam, this activity is designed to give you a chance to reflect on your exam performance and, more importantly, on the effectiveness of your exam preparation. Again, please answer the questions sincerely. Your responses will be collected to inform the instructional team; they will have no impact on your grade.'

Questions from one of the exam reflection sheets are listed below:

Questions Type A: These are evaluated twice, directly after the exam and after receiving the grading results, table 1 and table 2).

$\checkmark \quad$ Do you think that the problems on the exam fairly reflected the topics covered in class and recitation? (YES/NO)

$\checkmark \quad$ Did the grader's comments, together with the solutions, provide you with adequate feedback? (YES/NO) (evaluation only after receiving grading results)

Percentage questions are asked after the exam and after receiving grading results. The difference in $\%(\Delta)$ has to be filled in by students and optionally they can add a comment, according to their opinion why, if there is a delta, they answered these questions differently before and after learning their exam results.

$\checkmark \quad$ What percentage of the preparation for the exam was done alone and what percentage with one or more persons? ( $\%$ alone, $\%$ with other(s)). 
B. Oberer \& A.Erkollar: Exam Wrappers: Reflecting on the Study Skills of Freshmen in

MIS

$\checkmark \quad$ What percentage of your exam preparation time was spent with each of the following activities (to be answered in hours (h):

$\diamond$ Reading textbook section(s) for the first time: $\mathrm{h}$

$\diamond$ Re-reading textbook section(s):

$\diamond$ Reading additional materials: $\mathrm{h}$

$\diamond$ Reviewing homework solutions: $\mathrm{h}$

$\diamond$ Reworking old homework problems:

$\diamond$ Solving problems for practice:

$\diamond$ Reworking sample exams:

$\diamond$ Reviewing own notes:

$\diamond$ Working additional problems:

$\diamond$ Attending review sessions: $\mathrm{h}$

$\diamond$ Reviewing materials on the university wide learning platform: $\mathrm{h}$

What materials?

Approximately, how much time did you spend on preparing for the exam? $\mathrm{h}$ What aspect(s) of your preparation for this exam seemed different from your midterm exam preparation? Did these changes have any effect? (To be asked for the final exam)

Table 1: Evaluation structure for YES/NO questions

\begin{tabular}{|l|l|l|l|l||}
\hline \multirow{2}{*}{ Question } & \multicolumn{4}{|c||}{ Evaluation } \\
\cline { 2 - 5 } & \multicolumn{2}{|c|}{ After exam } & \multicolumn{2}{c|}{ After grading } \\
\hline Q1 & YES & NO & YES & NO \\
\hline Q2 & YES & NO & YES & NO \\
\hline Qn & YES & NO & YES & NO \\
\hline
\end{tabular}

Table 2: Evaluation structure for PERCENTAGE questions

\begin{tabular}{|l|c|c|c||}
\hline \multirow{2}{*}{ Question } & \multicolumn{3}{c||}{ Evaluation } \\
\cline { 2 - 4 } & After exam & After grading & Difference in $\%(\Delta)$ \\
\hline Q1 & $\%$ & $\%$ & \\
\hline Q2 & $\%$ & $\%$ & \\
\hline Qn & $\%$ & $\%$ & \\
\hline \hline
\end{tabular}

Questions Type B: these are evaluated after receiving the grading results.

$\checkmark \quad$ Now that you have looked over your exam, estimate the percentage of points you lost due to each of the following (ensure the percentages add up to 100):

$\diamond \quad \%$ from not being careful (mistakes,...)

$\diamond \quad \%$ from not understanding a concept

$\diamond \quad \%$ from not being able to formulate an approach or problem 
$1^{\text {ST }}$ INTERNATIONAL SCIENTIFIC CONFERENCE $\gg$ TEACHING METHODS FOR ECONOMICS AND BUSINESS SCIENCES «

Oberer \& A.Erkollar: Exam Wrappers: Reflecting on the Study Skills of Freshmen in MIS

$\diamond \quad$ \% from not being able to compare theories

$\diamond \ldots$ _ $\%$ from other reasons (please specify:

$\checkmark \quad$ Based on the estimate hereinabove, what will you do differently in preparing for the next exam? For instance, will you change your study habits or try to sharpen particular skills? Please be specific.

$\checkmark \quad$ What can your instructor do to help?

\section{$5 \quad$ Findings and discussion}

In this study, exam wrapper reflection analysis was applied for freshmen in management information systems at a higher education institution. In the two courses mentioned in this study, the exam wrapper reflection methodology was used several times; considering each course separately, it could be recognized that students get used to reflecting their performance before getting grading results more adequate than at the beginning.

Study Objective 1: students' metacognitive skills and abilities, such as goal setting and self-assessment

Goal setting

Table 3 was generated by the self-reported responses of students to the question 'How did you prepare for the exam?' Table 4 was generated on the results to the question 'What changes in your study habits do you plan when preparing for the next exam?' 
B. Oberer \& A.Erkollar: Exam Wrappers: Reflecting on the Study Skills of Freshmen in

Table 3: How did students prepare for the exams?

\begin{tabular}{||l|l|l||}
\hline \multicolumn{4}{|l|}{ Course MIS101: introduction to management information systems } \\
\hline Current Study strategy & Exam 1 & Exam 2 \\
\hline Reading textbook section(s) for the first time & 29 & 36 \\
\hline Re-reading textbook section & 22 & 35 \\
\hline Reading additional materials & 5 & 31 \\
\hline Reviewing homework solutions & 31 & 31 \\
\hline Reworking old homework problems & 25 & 35 \\
\hline Solving problems for practice & 8 & 11 \\
\hline Reworking sample exams & 12 & 15 \\
\hline Reviewing own notes & 34 & 36 \\
\hline Working additional problems & 0 & 13 \\
\hline Attending review sessions & 5 & 16 \\
\hline $\begin{array}{l}\text { Reviewing materials on the university wide learning } \\
\text { platform }\end{array}$ & 29 & 35 \\
\hline \multicolumn{2}{|l||}{} & \\
\hline Course MIS102: introduction to marketing & \multicolumn{2}{|l||}{} \\
\hline Current Study strategy & Exam 1 & Exam 2 \\
\hline Reading textbook section(s) for the first time & 43 & 52 \\
\hline Re-reading textbook section & 20 & 34 \\
\hline Reading additional materials & 1 & 15 \\
\hline Reviewing homework solutions & 32 & 43 \\
\hline Reworking old homework problems & 11 & 51 \\
\hline Solving problems for practice & 26 & 39 \\
\hline Reworking sample exams & 32 & 48 \\
\hline Reviewing own notes & 50 & 52 \\
\hline Working additional problems & 11 & 25 \\
\hline Attending review sessions & 10 & 16 \\
\hline $\begin{array}{l}\text { Reviewing materials on the university wide learning } \\
\text { platform }\end{array}$ & 32 & 51 \\
\hline \hline & \multicolumn{2}{|l||}{} \\
\hline
\end{tabular}


$1^{\text {ST }}$ INTERNATIONAL SCIENTIFIC CONFERENCE $\gg$ TEACHING METHOdS FOR ECONOMICS AND BUSINESS SCIENCES «

Oberer \& A.Erkollar: Exam Wrappers: Reflecting on the Study Skills of Freshmen in MIS

Table 4: Planned changes in study habits

\begin{tabular}{||l|l|l||}
\hline \multicolumn{3}{||l|l||}{ Course MIS101: introduction to management information systems } \\
\hline Planned Changes on Study strategy & Exam 1 & Exam 2 \\
\hline Spending more hours on studying & 12 & 18 \\
\hline Review on class notes regularly & 5 & 16 \\
\hline Form or join study groups & 1 & 52 \\
\hline Creating own notes & 0 & 4 \\
\hline Go to office hours and ask questions & 10 & 19 \\
\hline Attending review sessions & 22 & 45 \\
\hline Use online resources & 31 & 32 \\
\hline Pay more attention in class & 12 & 8 \\
\hline & \multicolumn{2}{||}{} \\
\hline Course MIS102: introduction to marketing & \multicolumn{2}{|l||}{} \\
\hline Planned Changes on Study strategy & Exam 1 & Exam 2 \\
\hline Spending more hours on studying & 23 & 34 \\
\hline Review on class notes regularly & 12 & 43 \\
\hline Form or join study groups & 3 & 35 \\
\hline Creating own notes & 0 & 6 \\
\hline Go to office hours and ask questions & 17 & 37 \\
\hline Attending review sessions & 12 & 32 \\
\hline Use online resources & 45 & 51 \\
\hline Pay more attention in class & 4 & 15 \\
\hline \hline
\end{tabular}

It is promising that the students were able to generate their own strategies. This does not necessarily mean that students were more successful in future exams or in following their future targets, but it shows that students are able to identify and reflect their learning strategies and prepare plans for future learning activities. The number of students attending the review sessions that were offered by the instructor doubled in both courses, the same for the number of students going to office hours asking questions on course topics or learning strategies. Students newly formed study groups and reviewed class notes regularly.

\section{Self-assessment}

To be able to evaluate how accurately students are able to self-assess their learning performance, their ability to correctly estimate their grade immediately could be taken as an indicator. Students were asked to fill in their predicted letter grade in the exam wrapper directly after the exam. These predictive grades were compared with their actual grades to be able to determine if the students (1) underestimated, (2) overestimated, or (3) correctly estimated their grades. Students were grouped into grade categories and the percentage of times those students over-, underestimated, or correctly estimated their exam grades were plotted by average exam grade category. By analyzing students' estimations, it could be recognized that students with higher exam grades tended to 
B. Oberer \& A.Erkollar: Exam Wrappers: Reflecting on the Study Skills of Freshmen in

underestimate their results while students with lower grades tended to overestimate their exam performance. This kind of trend could be seen for both exams of MIS101 and exam 2 for MIS102. According to Kruger and Dunning (1999), unskilled participants overestimate their performance, which is a result of their lack of metacognitive skills. According to them, an improvement in metacognitive skills would result in better exam results as well as improved self-assessment ability. In this study, exam wrappers were used to improve students' self-assessment ability.

\section{Study objective 2: correlation between study behaviors and student performance}

Students' current and planned study habits were compared with their exam grades, but no trend was recognized.

In a follow up study, it should be analyzed:

$\checkmark$ if there is a positive correlation between the number of study strategies used by students for preparing for exams and their exam grades,

$\checkmark$ if there is a positive correlation between students who used more effective study strategies, such as study group methods, and their exam grades.

$\checkmark$ if an improvement in metacognitive skills result in better exam results, and

$\checkmark$ the correlation between student study behavior, their exam performance, and final grade performance.

\section{Conclusions and recommendations}

The results of the study revealed that exam wrappers could make exams worth more than just the grade, transforming how instructors and students use exams as a tool for learning; directly influencing instructors' and students' behavior. Students learn to reflect their learning process, compare that to the outcome, and make the required adjustments, while instructors reflect on how students performed, compare the performance to the course related learning outcomes, and adjust, if necessary, their subsequent teaching to address the unmet needs. The process of reflection - comparison and adjustment - promotes a view of exams as part of a learning excellence cycle in which a refined understanding informs the changed behavior and in turn produces improved performance.

Exam wrappers are a useful reflection activity, but it is important to integrate reflection throughout the course; using a learning management system for implementing exam wrappers and other reflection activities might simplify data collection and data management.

Exam wrappers are useful as long as instructors are willing to adopt the results of this type of analysis in their teaching and are willing and able to talk to students about important details. The final goals should be to develop strong study skills that will benefit students throughout the institution. Exam wrapper reflection analysis is not only an 
$1^{\text {ST }}$ InTERnational SCIENTIFIC CONFERENCE $\gg$ TEACHING METHOdS FOR ECONOMICS AND BUSINESS SCIENCES «

Oberer \& A.Erkollar: Exam Wrappers: Reflecting on the Study Skills of Freshmen in MIS

exercise focusing on improving exam scores; it is an exercise to lead the development of learners.

\section{References}

Bransford, J. D., Brown A. L., \& Cocking R. (2000). How people learn: Brain, mind, experience, and school. Washington, D.C.: National Academy Press

Chick, N., Karis, T. \& Kernahan, C. (2009). Learning from their own learning: how metacognitive and meta-affective reflections enhance learning in race-related courses. International Journal for the Scholarship of Teaching and Learning, 3(1), 1-28.

Dewey, J. (1933). How we think. Lexington MA: Heath.

Kruger J., \& Dunning D. (1999). Unskilled and unaware of it: How difficulties in recognizing one's own incompetence lead to inflated self-assessments. Journal of Personality and Social Psychology, 77(6), 1121-1134.

Garner, R. (1990). When children and adults do not use learning strategies: Toward a theory of settings. Review of Educational Research, 60, 517-529.

Gezer-Templeton, G., Mayhew, E. J., Korte, D. S. \& Schmidt, S. J. (2017). Use of exam wrappers to enhance students' metacognitive skills in a large introductory food science and human nutrition course. Journal of Food Science Education, 16, 28-36.

Halpern, D. F. (1996). Thought and knowledge: An introduction to critical thinking. Mahwah, New Jersey: Lawrence Erlbaum Associates, Publishers.

Livingston, J. A. (1996). Effects of metacognitive instruction on strategy use of college students. Unpublished manuscript, State University of New York at Buffalo.

Roberts, M. J., \& Erdos, G. (1993). Strategy selection and metacognition. Educational Psychology, $13,259-266$.

Kegan, R., \& Lahey, L. L. (2009). Immunity to change: How to overcome it and unlock the potential in yourself and your organization. Boston: Harvard Business Review Press.

Lovett, M. C. (2013). Make exams worth more than the grade: Using exam wrappers to promote metacognition. In M. Kaplan, N. Silver, D. Lavaque-Manty, \& D. Meizlish (Eds.) Using reflection and metacognition to improve student learning (pp. 18-52). Sterling: Stylus Publishing.

Pintrich, P. R. (2002). The role of metacognitive knowledge in learning, teaching, and assessing. Theory into Practice, 41(4), 219-225.

Ramirez, G. \& Beilock, L. (2011). Writing about testing worries boosts exam performances in the classroom. Science, 331 (6014), 211-213.

Scheid, K. (1993). Helping students become strategic learners: Guidelines for teaching. Cambridge, MA: Brookline Books.

Schön, D. A. (1987). Educating the reflective practitioner: toward a new design for teaching and learning in the professions. San Francisco: Jossey-Bass.

Silver, N. (2013). Reflective pedagogies and the metacognitive turn in college teaching. In M. Kaplan, N. Silver, D. Lavaque-Manty, \& D. Meizlish. (Eds.), Using reflection and metacognition to improve student learning (pp. 1-17). Sterling: Stylus Publishing.

Sternberg, R. J. (1986). Inside intelligence. American Scientist, 74, 137-143.

Sternberg, R. J. (1984). What should intelligence tests test? Implications for a triarchic theory of intelligence for intelligence testing. Educational Researcher, 13(1), 5-15.

Winkelmes, M. (2013). Transparency in teaching: Faculty share data and improve students' learning. Liberal Education, 99(2), 48-55. 
B. Oberer \& A.Erkollar: Exam Wrappers: Reflecting on the Study Skills of Freshmen in

MIS

Zimmermann, B. J. (2000). Attaining self-regulation. In M. Boekaerts, P. Pintrich, \& M. Zeidner (Eds.), Handbook of self-regulation (pp. 13-39). San Diego: Academic Press. 


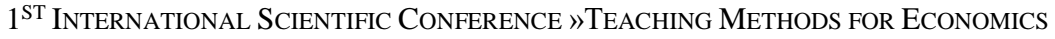
AND BUSINESS SCIENCES« 


\title{
Participative Approach and Experiential Learning Approaches for Students of Economics and Business
}

\author{
IGOR PERKO \& ZORAIDA MENDIWELSO BENDEK
}

\begin{abstract}
The paper examines the potentials of the applicability of experiential learning participative approach concepts and methods in the regular learning process for economics and business students. These approaches prove a high success rate in lifelong learning programs and in the learning of people with disabilities and those discarded from the society. First, the preferred properties of learning environment for the students of economics and business, as found in literature, are examined. Next, the main principles and results of participative approach and experiential learning are elaborated. In the synthesis, the desired properties are compared with the principles of the proposed methodologies. The report provides value-added for teachers and students in the regular learning process, equipping them with the methods that have proven a positive impact in lifelong learning. It also elaborates the gap between the desired properties in the regular learning process and the methodologies, potentially capable of closing this gap.
\end{abstract}

Keywords: • participative approach • experiential learning • regular learning process $\bullet$ lifelong study $\bullet$ disabilities $\bullet$

CoRrespondence AdDresses: Igor Perko, Ph.D., Assistant Professor, University of Maribor, Faculty of Economics and Business, Razlagova ulica 14, 2000 Maribor, Slovenia, e-mail: igor.perko@um.si. Zoraida Mendiwelso Bendek, Senior Research Fellow in Citizenship, University of Lincoln, Brayford Pool, Lincoln, Lincolnshire, LN6 7TS, United Kingdom, e-mail: zbendek@lincoln.ac.uk. 
$1^{\text {ST }}$ INTERNATIONAL SCIENTIFIC CONFERENCE $»$ TEACHING MeThods FOR ECONOMICS AND BUSINESS SCIENCES«

I. Perko, Z. Mendiwelso Bendek: Participative Approach and Experiential Learning Approaches for Students of Economics and Business

\section{$1 \quad$ Introduction}

The learning environment for students of economics and business is rapidly changing. We expect the students not only to understand the economic background mechanisms and to fit into the business environment but also to be the carriers of change, helping the companies to adapt to the new business challenges (European Commision, 2016). They are supposed to master the use and development of the latest IT tools to optimise and upgrade business processes.

Multiple approaches are proposed to upgrade the operational skills and the capacity to absorb the tacit knowledge of the students whilst still comprehending theoretical backgrounds. The development of information and communications technologies (ICT) provides us with numerous new options for the learning process execution. For instance, the appropriate use of multimedia, online learning, instant communication, remote cooperation and sharing of ideas in the educational is a major challenge (Kirkwood \& Price, 2014).

Nevertheless, ICT is merely an enabler, providing new tools for the old task: to deliver the appropriate connection of the theory and practice to learners, preparing them to be actionable in the real world. Successful learning process should join two opposite goals: first, the individual treatment of every student, providing tailor-made learning process, and, second, a high availability of the programs to the masses.

There are multiple examples of providing content to students. Case studies, for instance, are used to provide the situational insight, but indirectly support building new theoretical background (Welch, Piekkari, Plakoyiannaki, \& Paavilainen-Mantymaki, 2011). Nevertheless, for the cases to be well accepted, they must resolve issues which are close to students. The challenge remains how to deliver personalised contents to a large number of students, accessible by many and adapted to their personal needs (Kaplan \& Haenlein, 2016; Su, Huang, \& Ding, 2016).

Experiential learning and participative approach provide learners with an option to acquire their competencies in collaboration with the experts in resolving their issues. Teachers and learners use the approach to learn how to master the situations the learners will face in the future, how to connect with the environment to resolve the challenges (Mayo, 2013; Mendiwelso-Bendek et al., 2013; Richards, 2014). Experiential learning and participative approach are mostly used in learning with the community groups and people with disabilities. The methodologies are considered time- and resource-consuming since they require active engagement of all of the participants and have, therefore, not been preferred in regular higher education curriculum.

In this paper, the research question is focused on the applicability of experiential learning and participative approach methods in the regular teaching process for the students of economics and business. We assume that these approaches could be used in regular teaching process if suitably supported with the state-of-the-art ICT technology. 
I. Perko, Z. Mendiwelso Bendek: Participative Approach and Experiential Learning Approaches for Students of Economics and Business

The research starts with the state-of-the-art analysis of teaching environment that enables students of economics and business to build their competencies favoured by the employers now and in the future. In the next step, we focus on the analysis of the main concepts of experiential learning and participative approach. We try to identify examples, the value added and the shortcomings of the methodologies in the perspective of using them on a large scale. In the synthesis, we elaborate the potentials of applying the proposed approaches in the dedicated environments with the state of the art ICT as an enabler and propose the processes for the successful introduction of experiential learning and participative approach to the teaching environment for the students of economics and business. The research is limited to assessing the potentials and the proposition of the introductions steps. Thereby, we are not in the capacity of assessing the success of introduction or the effects of the proposed approaches, to the regular teaching process.

\section{Teaching environment for the students of Economics and Business}

In the first step, the preferred properties of the learning environment for the students of economics and business found in the literature are examined.

The research in teaching methods for teaching graduate and post-graduate students is vivid and provides evidence of upgrading the processes to allow students a more productive involvement in the education process. The research heads in two quite contrasting directions: first, the options to involve large numbers of students in the educational process, and the second, providing the highest level of quality by delivering the contents in the educational process, adapted to the student individual needs, expectations and capacities.

Students should gain multiple competencies and advance their insight on the topics of business and economics. In Table 1, the linkage between skills acquired in youth work, and the requirements of the labour market is presented. 
$1^{\text {ST }}$ INTERNATIONAL SCIENTIFIC CONFERENCE $\gg$ TEACHING METHOdS FOR ECONOMICS AND BUSINESS SCIENCES«

I. Perko, Z. Mendiwelso Bendek: Participative Approach and Experiential Learning Approaches for Students of Economics and Business

Table 1: Correspondence between skills in youth work and the labour market

\begin{tabular}{|c|c|c|}
\hline $\begin{array}{l}\text { Overarching skill } \\
\text { categories }\end{array}$ & $\begin{array}{l}\text { Outcomes identified in the } \\
\text { research literature }\end{array}$ & $\begin{array}{l}\text { Skills identified by } \\
\text { employers }\end{array}$ \\
\hline $\begin{array}{c}\text { Personal } \\
\text { (confidence and } \\
\text { self-esteem) }\end{array}$ & $\begin{array}{l}\text { - Increased confidence and self- } \\
\text { esteem } \\
\text { - Self-awareness (personal and } \\
\text { social) } \\
\text { - Readiness to take on new and } \\
\text { more diverse experiences }\end{array}$ & $\begin{array}{l}\text { - Adaptability and } \\
\text { flexibility }\end{array}$ \\
\hline $\begin{array}{l}\text { Interpersonal } \\
\text { (social and } \\
\text { communication } \\
\text { skills, teamwork, } \\
\text { assertiveness) }\end{array}$ & $\begin{array}{l}\text { - Improved teamwork } \\
\text { - Increased communication } \\
\text { - Improved pro-social behaviour } \\
\text { - More open to people from } \\
\text { diverse backgrounds } \\
\text { - Positive peer relationships } \\
\text { - Enhanced leadership }\end{array}$ & $\begin{array}{l}\text { - Leadership } \\
\text { - People management } \\
\text { and teamwork } \\
\text { - Influencing } \\
\text { - Communication }\end{array}$ \\
\hline $\begin{array}{l}\text { Self-management } \\
\text { skills (e.g. } \\
\text { reliability) }\end{array}$ & $\begin{array}{l}\text { - Motivation, commitment, } \\
\text { resilience } \\
\text { - Increased life skills }\end{array}$ & $\begin{array}{l}\text { - Innovation and } \\
\text { entrepreneurship }\end{array}$ \\
\hline $\begin{array}{l}\text { Competencies in } \\
\text { initiative and } \\
\text { delivery (planning, } \\
\text { problem-solving, } \\
\text { prioritising) }\end{array}$ & $\begin{array}{l}\text { - Critical thinking skills } \\
\text { - Planning, decision-making } \\
\text { - Developed and focused career } \\
\text { aspirations }\end{array}$ & $\begin{array}{l}\text { - Change management } \\
\text { - Project management } \\
\text { - Decision making } \\
\text { - Time management }\end{array}$ \\
\hline
\end{tabular}

(Bamber and group, 2012)

The competencies, required by the employers in the future, according to the Institute for the Future (2011) are:

- Social intelligence,

- Adaptive thinking,

- Cross-cultural competencies,

- Multimedia literacy, and

- Virtual collaboration.

The relations between topics versus competencies are often comprehended as the understanding of the backgrounds versus the ability to act. The art of delivering the appropriate topics, to build up the required skills and competencies that are perceived by the learned as appropriate is a challenging task.

Revell and Wainwright (2009) examine the perceptions of academics and students as to what makes a lecture 'unmissable'. The findings show three significantly factors: (i) a high degree of participation and interactivity ('active learning'), (ii) a clear structure which 
I. Perko, Z. Mendiwelso Bendek: Participative Approach and Experiential Learning Approaches for Students of Economics and Business

enables integrative links to be more easily made, and (iii) a passionate, enthusiastic lecturer, who can bring a subject to life for students. As research has shown that a high degree of interactivity encourages deeper approaches to learning, the paper argues that a move away from conventional lecturing towards more applied methods and small-group teaching may be a way of improving teaching excellence.

There are multiple examples of providing real-life content to the students. Case studies, for instance, are used to provide the situational insight, but with appropriate interpretation indirectly support building new theoretical background (Welch et al., 2011). Nevertheless, for the cases to be well accepted, cases must resolve issues, close to students. The challenge remains how to deliver real-life content to a large number of students, accessible by many and adapted to their personal needs. (Kaplan \& Haenlein, 2016; Su et al., 2016).

Teachers and students are using new technologies to resolve some of teaching challenges. Among others, new technologies should support learning by enabling:

- ubiquitous access to the working environment,

- remote presence to the lectures and recordings access,

- interactive use of multimedia materials,

- individual learning speed support and continuous progress monitoring,

- multilingual access to the materials, and

- seamless communication in project groups.

Even though new technologies support the learning process, the contents and the execution of learning resides in the quality of the interaction during this process. The interaction in experiential learning and participative approach could provide additional value to the learning process to students in business and economics.

\section{$3 \quad$ Experiential learning}

Experiential learning is the process of learning through experience and is more specifically defined as "learning through reflection on doing" (Wikipedia, 2017). Experiential learning provides the student with an option to gather its own experience. It can be provided in multiple forms, ranging from passively observing and event, through experiencing the effects, actively involving as an individual or a member of a team, to managing and planning the event.

Although it is presumed that in experiential learning the teacher plays a comparatively passive role, supporting the student in gathering, understanding and remembering the body of knowledge through experience, the road to success may be a different one. To deliver a successful learning experience, the teacher must also be challenged (re)experience the case and - hopefully, gain new insights resulting from the interaction with the student (Revell \& Wainwright, 2009). 
$1^{\text {ST }}$ INTERNATIONAL SCIENTIFIC CONFERENCE $\gg$ TEACHING METHODS FOR ECONOMICS AND BUSINESS SCIENCES«

I. Perko, Z. Mendiwelso Bendek: Participative Approach and Experiential Learning Approaches for Students of Economics and Business

In the terms of resources spent by the teacher, the student and the learning environment, experience learning is a very high-cost learning method, but providing high-level results.

According to Kolb and Kolb (2005), experiential learning is repetitive, as depicted in Figure 1. The process starts with concrete experience, involves observation, conceptualisation and finishes with planning for new experiences.

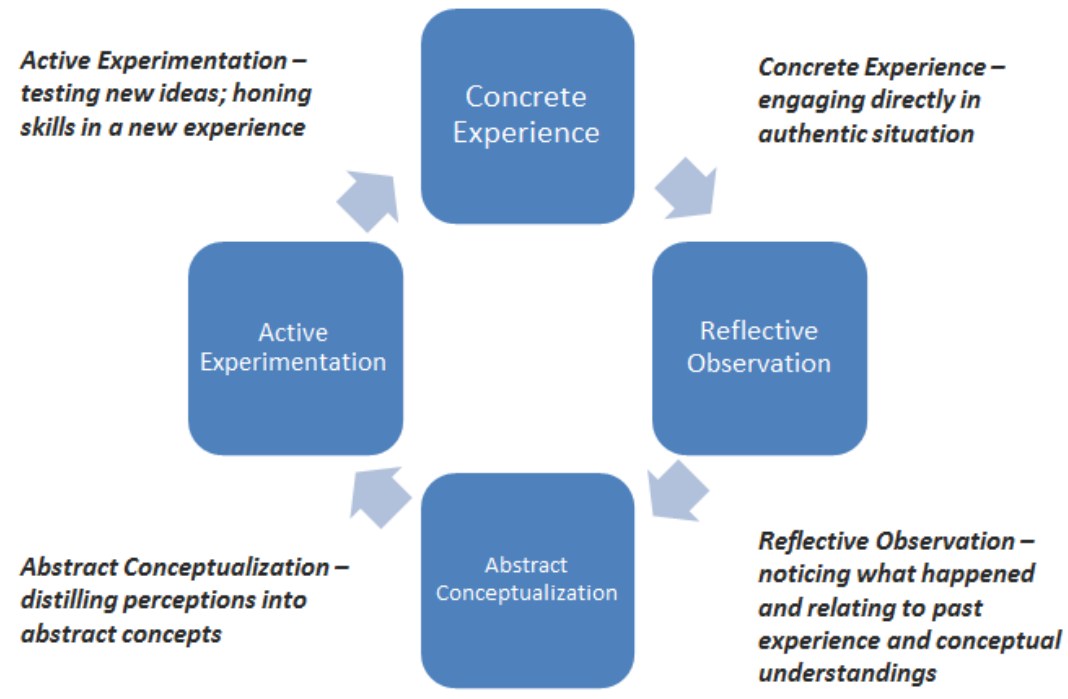

Figure 7: Cycle of experiential learning (Kolb \& Kolb, 2005)

There is a vast variety of experiential learning examples at multiple levels of complexity:

- Internship is often a credit-bearing, free standing activity in a student's field of interest not connected to a theoretical course.

- Case studies are in classroom examinations of real-life examples.

- Cooperative education: students gain practical relevant work experience over a period of multiple terms that intersperse their coursework.

- Student teaching: his experience is specific to students in pre-professional and pre-service teacher education who are gaining required and evaluated experience in supervised teaching.

- Practicum: a relative of the internship, this form of experiential learning usually is a course or student exercise involving practical experience in a work setting.

- Undergraduate research experience: students function as research assistants and collaborators on faculty projects.

- Community-based research: faculty and students cooperate with local organisations to conduct studies to meet the needs of a particular community. 
I. Perko, Z. Mendiwelso Bendek: Participative Approach and Experiential Learning Approaches for Students of Economics and Business

- Field work: supervised student research or practice carried out away from the institution and in direct contact with the people, natural phenomena, or other entities being studied.

- Study abroad: students usually engage in courses at higher education institutions in another country.

There are multiple research reports on experiential learning results. Lantz, Hansen and Antoni (2015) explore job design mechanisms that enhance team proactivity within a lean production system where autonomy is uttermost restricted. They suggest that team learning process builds the shared meaning of work and mediates the relationship between team participative decision-making, inter-team relations and team proactive behaviour.

Kakouris (2015) addresses an instructional perspective for entrepreneurship courses, where critical thinking is connected with experiential learning in a common framework thus facilitating entrepreneurship education for various heterogeneous populations through lifelong learning or vocational training. He suggests the conceptualization through critical instruction either to resolve disorienting situations or to lead to postponement of courses and reconsideration of the theoretical framework.

Checkland (2010) summarises the programme of action research which ran for 30 years and provides reflections on the experience of social development gained during that research.

Hemetsberger and Reinhardt (2006) elaborate learning and building collective knowledge by the members of innovative online communities through the use of 'technologies' and the establishment of discursive practices that enable virtual re-experience. They review the theories of knowledge creation and learning and suggest that re-experience is enabled by code, transactive group memory, instructive content and discourse, and reflective discourse. The manifestations of learning processes lead to concrete experience, reflective observation, abstract conceptualization, and active experimentation at the individual level. Collective reflection, collective conceptualization, virtual experimentation, and participative practice are initiated at the social level.

Experiential learning is used in organisations as a part of preparing employees for new tasks and positions; while in faculties, it is used as a supplementary part of the curriculum. A relatively low level of experiential learning in faculties can be deducted to its high price. All the participants, i.e. the teachers, the students and the institution, must dedicate a high level of resources to actively execute experiential learning methods in the learning process.

Since the experiential learning is universal, it can support any domain of knowledge, and involve experiences on multiple levels of complexity, the question arises what kind of experiential learning would provide the most value added for the students of business and economy. To help understand basic topics, simple examples are adequate, but to provide 
I. Perko, Z. Mendiwelso Bendek: Participative Approach and Experiential Learning

Approaches for Students of Economics and Business

a higher-level understanding of complex business, economic and social processes, more complex experiential models, such as the participative approach, may be appropriate.

\section{$5 \quad$ Participative approach}

Participative approach in its original form is intended to support active citizenship (Mendiwelso-Bendek et al., 2013) in order to:

- build the skills and confidence of local people so that they can pursue civic activism, community leadership and lay governance roles (including local councillor),

- $\quad$ support people and organisations in developing an understanding of barriers to participation, and how to overcome them,

- $\quad$ raise awareness of routes into lay governance roles, especially those involving local strategic partnership partners, and

- support people in their progression through those routes to enable improvement against public service agreement national indicators.

Participative approach is partially in conflict with the traditional teaching aspect, stating that the purpose of teaching process is to form individuals capable of fitting into existing organisations and executing the predefined tasks and services in the name of that organisation.

The participative approach is designed to equip the learners with the skills required to address the complexity of the environment, not only to thrive but also to actively change it for the better. It joins the understanding of the environment they operate in, the method on how to apply changes, and the outcome of the changes they will imply. It provides understanding that they have the power to change the environment by supporting them in executing their activities and helping them to connect with the society.

Participative approach was originally focused on people that lived on the edge of the system and did not have the organisational support to provide the change, i.e. the deprived people who do not comply with the traditional education system and may have abandoned it. It was adopted as one of learning techniques to support active citizenship by providing support and experiences of other people and groups in similar situations. 
I. Perko, Z. Mendiwelso Bendek: Participative Approach and Experiential Learning Approaches for Students of Economics and Business

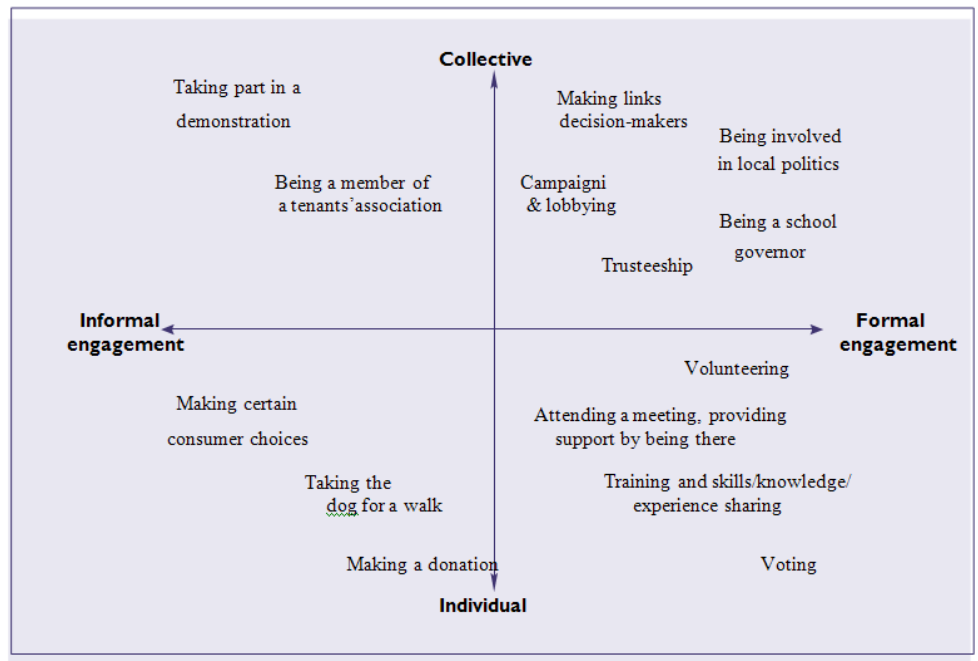

Figure 8: Different types of active citizenship practices (Jochum, Pratten \& Wilding, 2005)

Participative approach plays a significant role in the engaging youth in experiencing processes. Freire's approach to community education and experiential learning is a cornerstone of Active Citizenship Learning international programs. The approach is based on constant dialogical and dialectic reflection, observation and understanding of the power structures. It enables individual and collective to develop a critical understanding of their realities and contexts in order to develop strategies for social transformations (Freire, 1972). Offering opportunities within the learning in processes that influence decision making (Mendiwelso-Bendek, 2015).

The complexity of participatory approach surpasses standard teaching methods and requires more effort of all of the participants. Somech (2002)proposes a multidimensional approach to introducing participative management and examines five dimensions: decision domain, degree of participation, structure, target of participation, and rationale. Guerin, van der Ploeg, and Sins (2013), on the other hand, report on issues in applying participative approach in standard curriculum and argue three kinds of constraints that make the implementation of such a participative approach unrealistic: (1) insufficient specialist knowledge on the part of teachers and head teachers, (2) time and budget constraints, and (3) an overcrowded curriculum.

Subramaniam (2012) explores the concept of lifelong learning programmes implemented in the Malaysian Community Colleges in terms of goals, types and features. He reveals that age, gender, occupational strata, and qualifications were not a barrier to participation and that the variety of courses, including specialised courses offered for a nominal fee in the community colleges, attracted participation from different members of the community. 
$1^{\text {ST }}$ INTERNATIONAL SCIENTIFIC CONFERENCE $\gg$ TEACHING METHOdS FOR ECONOMICS AND BUSINESS SCIENCES«

I. Perko, Z. Mendiwelso Bendek: Participative Approach and Experiential Learning Approaches for Students of Economics and Business

In Table 2, the connections between citizen learning process and the citizenship outcomes are presented. These skills and capabilities are essential for active involvement in EU environment.

Table 2: Aspects of active citizenship

\begin{tabular}{|c|c|c|}
\hline $\begin{array}{l}\text { Aspects of } \\
\text { Active } \\
\text { Citizenship }\end{array}$ & $\begin{array}{c}\text { Citizen learning processes: } \\
\text { I feel able to...I know more } \\
\text { about... } \\
\text { I know how to... } \\
\end{array}$ & $\begin{array}{l}\text { Citizenship outcomes: } \\
\text { Local, national, European } \\
\text { and global dimensions }\end{array}$ \\
\hline Personal & $\begin{array}{l}\text { - Value my own skills, } \\
\text { knowledge and confidence } \\
\text { - Know where to go to get what I } \\
\text { need } \\
\text { - Communication skills, } \\
\text { negotiation skills, lobbying skills } \\
\text { - Feel able to have a voice }\end{array}$ & $\begin{array}{l}\text { - People identity and articulate } \\
\text { their issues and problems } \\
\text { - People take leadership roles } \\
\text { in their community } \\
\text { - People have the power and } \\
\text { will to make choices in their life } \\
\text { - People voice their concerns }\end{array}$ \\
\hline $\begin{array}{l}\text { Community } \\
\text { relations }\end{array}$ & $\begin{array}{l}\text { - Recognise that social exclusion } \\
\text { is the responsibility of all } \\
\text { - Understand how their behaviour } \\
\text { affects others } \\
\text { - Know the basis of inequality and } \\
\text { how power operates } \\
\text { - Understand more about people } \\
\text { who are different to themselves } \\
\text { - Feel more confident in asking }\end{array}$ & $\begin{array}{l}\text { - Improved relations between } \\
\text { diverse groups of people } \\
\text { - Community projects are } \\
\text { inclusive of people with } \\
\text { different backgrounds } \\
\text { - Increased points of contact } \\
\text { between different communities } \\
\text { - Increased networking } \\
\text { between communities }\end{array}$ \\
\hline $\begin{array}{c}\text { Civil } \\
\text { participation }\end{array}$ & $\begin{array}{l}\text { - Understand how } \\
\text { groups/networks work } \\
\text { - Know how to encourage fair } \\
\text { and democratic decision-making } \\
\text { - Understand how to encourage } \\
\text { support and develop volunteers } \\
\text { - Know the importance of } \\
\text { networking and delivering change } \\
\text { - Chairing, meeting and } \\
\text { facilitation skills } \\
\text { - Negotiation and campaigning }\end{array}$ & $\begin{array}{l}\text { - More civil society groups } \\
\text { active in community-led service } \\
\text { provision } \\
\text { - Well-run democratic } \\
\text { community groups } \\
\text { - Increased informal } \\
\text { community organising } \\
\text { - Increased networking } \\
\text { between } \\
\text { community and voluntary } \\
\text { groups } \\
\text { - Effective representation in } \\
\text { partnership and involvement } \\
\text { with public bodies } \\
\text { - Increased volunteering } \\
\text { opportunities }\end{array}$ \\
\hline $\begin{array}{c}\text { Civic } \\
\text { engagement }\end{array}$ & $\begin{array}{l}\text { - Knowing how the external } \\
\text { world operates }\end{array}$ & $\begin{array}{l}\text { - More people want to and feel } \\
\text { capable of having a responsible }\end{array}$ \\
\hline
\end{tabular}


I. Perko, Z. Mendiwelso Bendek: Participative Approach and Experiential Learning Approaches for Students of Economics and Business

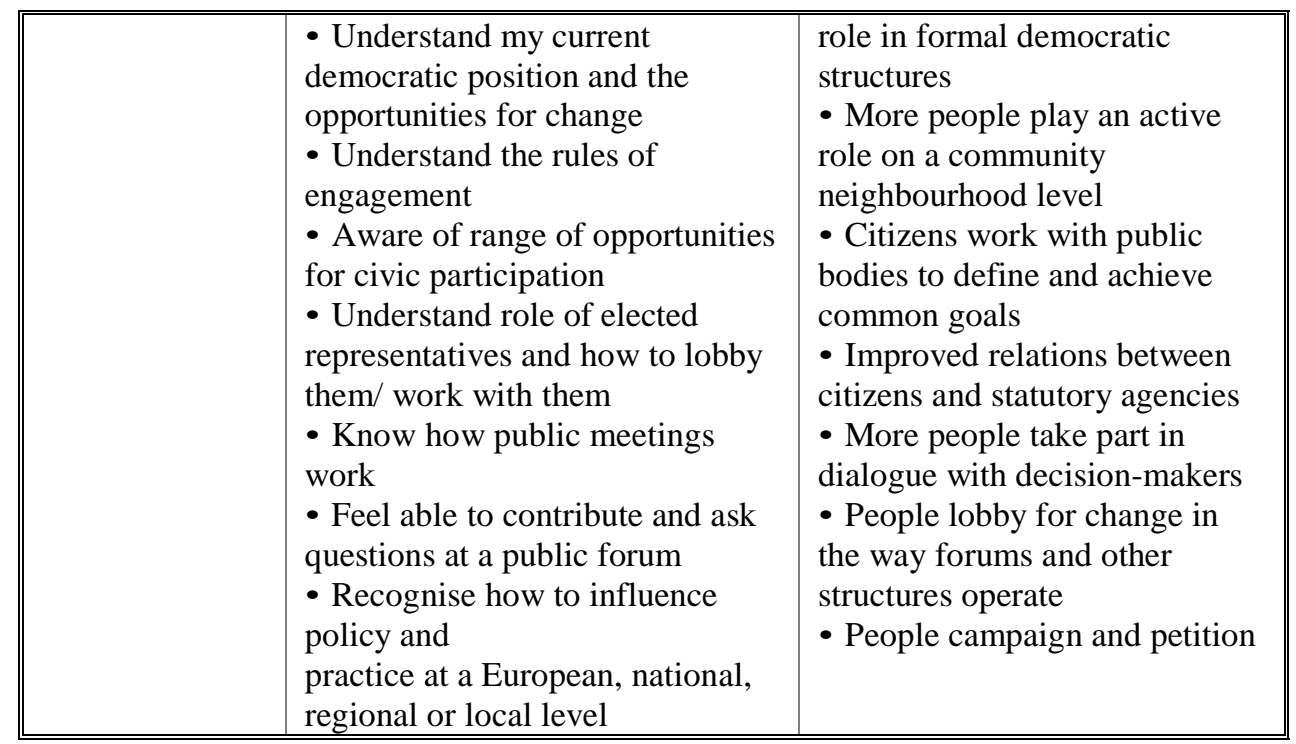

(Mendiwelso-Bendek et al., 2013)

\section{Synthesis and conclusion}

Experiential learning and participative approach address multiple current and future key competencies of students for the business environment and for their personal growth.

Personal: confidence, self-esteem, self-awareness, readiness to take on new and more diverse experiences, adaptability and flexibility, multimedia literacy. All of these can be acquired by positive feedback in experience learning and participatory approach, by valuing their own skills, knowledge and confidence to have the power and will to make choices in their life. The technology insight may give them the required feeling that they can contribute something new to the environment.

Interpersonal: teamwork, communication, pro- and inter-social behaviour, leadership people management, social intelligence, cross-cultural competencies, virtual collaboration. To acquire these skills, experience learning and participatory approach are of immense importance since these can only be tested in real-life scenarios. Mastering virtual collaboration will enable them to acquire cross-cultural experiences by cooperating in virtual multi-cultural teams.

Initiative and delivery: critical thinking, planning, decision-making, developed and focused career aspirations, change management, project management, decision making, time management, adaptive thinking. To test these skills, experience learning is crucial. Since for the standard situations, the best of breed solutions are predefined the theory, the experience in simulations or gaming environment can play a major role. 
$1^{\text {ST }}$ INTERNATIONAL SCIENTIFIC CONFERENCE »TEACHING METHOdS FOR ECONOMICS AND BUSINESS SCIENCES«

I. Perko, Z. Mendiwelso Bendek: Participative Approach and Experiential Learning Approaches for Students of Economics and Business

Both experiential learning and participative approach post high demands for the involvement of all of the involved parties: the students, the teachers and the organisation. Therefore, their use is currently limited. With the use of technology, supporting the creation of virtual teams with nearly unlimited communication capabilities, the organisational effort may be lessened, but the involvement of the teacher and the students must remain at the highest possible level if the results, we are hoping for are to be achieved.

\section{References}

Bamber, J. (2014). Developing the creative and innovative potential of young people throught non-formal learning in ways that are relevant to employability. European Commission Youth: Expert Group Report. Retrieved from http://ec.europa.eu/youth/library/reports/creative-potential_en.pdf

Checkland, P. (2010). Researching real-life: Reflections on 30 years of action research. Systems Research and Behavioral Science, 27(2), 129-132. http://dx.doi.org/10.1002/sres.1019

European_Commision. (2016). EU youth report 2015 Retrieved from http://ec.europa.eu/youth/library/reports/youth-report-2015_en.pdf

Freire, P. (1972). Pedagogy of the oppressed. Harmondsworth: Penguin.

Guerin, L. J. F., van der Ploeg, P. A., \& Sins, P. H. M. (2013). Citizenship education: The feasibility of a participative approach. Educational Research, 55(4), 427-440. http://dx.doi.org/10.1080/00131881.2013.844945

Hemetsberger, A., \& Reinhardt, C. (2006). Learning and knowledge-building in open-source communities - A social-experiential approach. Management Learning, 37(2), 187-214. http://dx.doi.org/10.1177/1350507606063442

Jochum, V., Pratten, B., \& Wilding, K. (2005). Civil renewal and active citizenship a guide to the debate. Retrieved from https://www.ncvo.org.uk/.../civil_renewal_active_citizenship.pdf

Kakouris, A. (2015). Entrepreneurship pedagogies in lifelong learning: Emergence of criticality? Learning Culture and Social Interaction, 6, 87-97. http://dx.doi.org/10.1016/j.lcsi.2015.04.004

Kaplan, A. M., \& Haenlein, M. (2016). Higher education and the digital revolution: About MOOCs, SPOCs, social media, and the Cookie Monster. Business Horizons, 59(4), 441450. http://dx.doi.org/10.1016/j.bushor.2016.03.008

Kirkwood, A., \& Price, L. (2014). Technology-enhanced learning and teaching in higher education: what is 'enhanced' and how do we know? A critical literature review. Learning Media and Technology, 39(1), 6-36. http://dx.doi.org/10.1080/17439884.2013.770404

Kolb, A. Y., \& Kolb, D. A. (2005). Learning styles and learning spaces: Enhancing experiential learning in higher education. Academy of Management Learning \& Education, 4(2), 193212. http://dx.doi.org/10.5465/amle.2005.17268566

Lantz, A., Hansen, N., \& Antoni, C. (2015). Participative work design in lean production: A strategy for dissolving the paradox between standardized work and team proactivity by stimulating team learning? Journal of Workplace Learning, 27(1), 19-33. http://dx.doi.org/10.1108/jwl-03-2014-0026

Mayo, P. (2013). Reconceptualizing lifelong learning. Political Sociology of Adult Education, 711. http://dx.doi.org/Book_Doi 10.1007/978-94-6209-227-3

Mendiwelso-Bendek, Z. (2015). Community-based research: enabling civil society's selforganisation. Kybernetes, 44(6-7), 903-912. http://dx.doi.org/10.1108/k-02-2015-0056 
I. Perko, Z. Mendiwelso Bendek: Participative Approach and Experiential Learning Approaches for Students of Economics and Business

Mendiwelso-Bendek, Z., Recknagel, G., Hartley, T., Rooke, A., Mayo, M., Packham, C., \& Milburn, K. (2013). TAKE PART UK Learning Framework. Retrieved from http://takepartresearchcluster.blogs.lincoln.ac.uk/files/2013/07/13946_Take-part-learningframework-final-2011.pdf

Revell, A., \& Wainwright, E. (2009). What makes lectures 'unmissable'? Insights into teaching excellence and active learning. Journal of Geography in Higher Education, 33(2), 209223. http://dx.doi.org/10.1080/03098260802276771

Richards, L. (2014). Education as a subversive activity: a proposal. Kybernetes, 43(9-10), 13921398. http://dx.doi.org/10.1108/k-07-2014-0149

Somech, A. (2002). Explicating the complexity of participative management: An investigation of multiple dimensions. Educational Administration Quarterly, 38(3), 341-371. http://dx.doi.org/10.1177/0013161x02383003

Su, Y. S., Huang, C. S. J., \& Ding, T. J. (2016). Examining the effects of MOOCs learners' social searching results on learning behaviors and learning outcomes. Eurasia Journal of Mathematics Science and Technology Education, 12(9), 2517-2529. http://dx.doi.org/10.12973/eurasia.2016.1282a

Subramaniam, S. R. (2012). Lifelong learning programmes for sustainable development. AsiaPacific Education Researcher, 21(3), 625-635.

The Institute for the Future. (2011). Future work skils. Retrieved from http://www.iftf.org/uploads/media/SR-1382A_UPRI_future_work_skills_sm.pdf

Welch, C., Piekkari, R., Plakoyiannaki, E., \& Paavilainen-Mantymaki, E. (2011). Theorising from case studies: Towards a pluralist future for international business research. Journal of International Business Studies, 42(5), 740-762. http://dx.doi.org/10.1057/jibs.2010.55

Wikipedia.(2017). Experiential learning. Retrieved from https://en.wikipedia.org/wiki/Experiential_learning 
$1^{\text {ST }}$ INTERNATIONAL SCIENTIFIC CONFERENCE $\gg$ TEACHING METHOdS FOR ECONOMICS AND BUSINESS SCIENCES« 


\title{
Simulations as a Teaching Method in Public Economics
}

\author{
JAVIER SIERRA
}

\begin{abstract}
This paper presents a new teaching method used within the framework of the course on Public Economics and Economics of the European Union in the Grade on Business Administration at the University of Salamanca. The aim of this methodology is to allow students to get a first-hand experience on Public Economics management at three different levels: local, national and international. This method is based on three different simulations through which students may apply their knowledge as regards the decision-making process in a practical an innovative way. Public Economics management at local level is simulated using the SIMCITY computer game; the decision-making process at national level is experienced by a simulation of the Congreso de los Diputados (the Spanish National Parliament); and a simulation of the ECOFIN is organised to offer students a first-hand experience of the mechanisms to manage Public Economics at international level. The results of the activities show that this approach contributes to a better learning of Public Economics management. This method has proven its worth as a valuable tool to increase student's interest and knowledge on public economic management at different levels.
\end{abstract}

Keywords: • simulation $\bullet$ teaching $\bullet$ innovation $\bullet$ technology $\bullet$ practical $\bullet$

CORRESPONDENCE AdDRESS: Javier Sierra, Ph.D. candidate, Lecturer, University of Salamanca, Faculty of Law, Department of Applied Economics, C/ Francisco Tomás y Valiente, 37007 Salamanca, Spain, e-mail: jsierra@usal.es. 
$1^{\text {ST }}$ INTERNATIONAL SCIENTIFIC CONFERENCE $\gg$ TEAChING MethodS FOR ECONOMICS AND BUSINESS SCIENCES«

J. Sierra: Simulations as a Teaching Method in Public Economics

\section{$1 \quad$ Introduction}

One of the main goals of the European Higher Education Area (EHEA) is to develop an increasingly knowledge-based learning system able to facilitate the development of student's skills and competences (European Commission/EACEA/Eurydice, 2015). For this purpose, study plans within the framework of the EHEA aim to provide students with a set of multi-dimensional skills, in addition to traditional theoretical knowledge of traditional study plans (ENQA, 2015).

Among these relatively new curricular skills, we may find several student-centred pedagogies such as teamwork, public speaking, research skills, management of new technologies and use of social networks (Watts \& Schaur, 2011). At the same time, study programs focus on the need of organising in-class practical activities closely linked to real-life situations and institutions (Becker \& Watts, 2001). If we add to this scenario that total course duration and classroom hours have been reduced, this new context may be highly challenging for teachers (Babcock \& Mars, 2011).

Teaching to large groups may also impose limitations on teaching methods and evaluation frameworks (Harter et al., 1999) as large groups are more likely to be evaluated using multiple choice tests and other online tools at the expense of a lower use of other assessment methods such as essays or other writing assignments (Harter et al., 2015). Even though new technologies offer a wide range of teaching tools and learning options, in class experiments and simulations may help to increase student engagement and interaction (Carter \& Emerson, 2012).

This article presents a new teaching method based on three different simulations which allow students to take an active role in their own learning. The main goal of this new method is to foster students' education using a new learning approach. This new method includes three different activities that have been organised separately in the last three years, within the framework of the courses Public Economics and Tax System and Economics of the European Union, both from the Grade of Business Administration at the University of Salamanca.

Due to their experimental characteristics, these three simulations were organised as optional evaluation activities within the framework of the continuous assessment for the course. In addition to the simulations, the continuous assessment includes another two activities: a weekly practical assignment and a book reading. As regards the weekly assignment, students submit a short essay answering a set of questions that mix theoretical exercises with the analysis of current issues based on public reports and news updates. Then, students have the option to discuss it with their colleagues in a weekly seminar session. As regards the book reading, the teacher proposes a book list and students work on a critical assignment, which is then submitted and discussed in a specific seminar ${ }^{1}$. We wish to highlight that approximately $60 \%$ of students have participated in the optional activities during the last two years. 


\section{$2 \quad$ Methodology}

\subsection{Teaching approach}

This learning method is based on three different simulations that allow students to implement the acquired theoretical concepts in a practical manner. Each of the three activities is designed to address Public Economics management at local, national and international levels. These three simulations allow student to develop a set of useful skills such as critical analysis, research skills and time management. Furthermore, each simulation enables students to develop and improve a set of specific skills related to different Public Economics scenarios, such as the use of new technologies, timemanagement, negotiation skills, teamwork, public speaking and use of English for academic and professional purposes.

The general framework which applies to all simulations is structured as follows: (1) a specific problem-scenario with different social and economic problems that need to be solved by students in a limited time; (2) an analysis exercise focused on problem-solving proposals; and (3) a debate and negotiation phase focused on finding solutions for the proposed problem. Since it is an experimental method, it will only be used for the assessment of those students who want to participate in the three activities (weekly assignment, book reading and simulations), but all enrolled students will have the chance to participate in the simulations. The specific characteristics of the three simulations and the set of skills developed on each are explained below.

\subsection{The simulations}

\subsubsection{Public Economics at the local level: SIMCITY}

The first of the three simulations focuses on the decision-making process at the local level. To practise Public Economics management problems at this level we use the SIMCITY computer game. The main goal of this game is to create cities and to manage their further development into more complex societies that interact with other towns. The initial scenario requires players to choose the location of their future city among different geographical environments with specific characteristics. These features include different locations (distance to sea, rivers, mountains, lakes, etc.), availability of natural resources (water sources, oil, wind, mineral resources, potential solar energy, etc.), the distance to other potential cities and land configuration, among other characteristics.

Once students have chosen the location for the new city, they have to take a set of decisions to develop a proper system of public services for their newly arrived citizens. During the first stage players take decisions to develop basic infrastructure and public services such as new roads, streets, water, electricity and sanitary services. They are also required to take urban planning decisions to divide land into the three possible uses: residential areas, commercial areas and industrial estate. At this point students need to 
pay attention to issues like connection to highways or railways, access to sea and environmental conditions such as wind direction or aquifer quality.

The level of difficulty of the required decisions increases over time, as the society evolves to a more complex environment where people demands local authorities to improve the basic services and to implement better and more diverse interventions to increase welfare standards. One important decision at this point is to decide the overall orientation of the whole town, and players may choose between several options to direct public investments to develop cities focused on tourism, culture, industry, the gaming sector, or trade, for example. For this purpose, they have to make investments to attract private actors, which in turn demand further public spending to improve accessibility, security conditions, waste management, and accommodation and transportation services, among many other social demands. All decisions are limited by two key factors: the public budget and citizen satisfaction. Following the game's dynamics, these two factors also increase their complexity in terms of information and management. For example, while in the first stage student may decide only to manage only one tax, in further stages the taxing systems increases its diversity, and students may use a broader range of taxes and tax rates tailored to different activities and income levels. In addition to this, it is increasingly complicated to meet the needs of citizens, industries and business established in the city.

SIMCITY is an excellent tool to allow students to discover first-hand how difficult it is to manage public budgets at the local level to meet social demands, and to realise to what extent it is complicated to balance interests from all involved stakeholders. Thanks to this activity, students understand the complexity of the decision-making process to improve existing public services and to implement new ones. In a short session of three or four hours, students are able to apply theoretical knowledge to real problems in a practical manner, and to increase their knowledge about how these interventions are managed. It helps to increase awareness about the importance of public services at the local level and the high complexity of the daily activities of local authorities.

This activity is undertaken individually in one of the several computer classroom of the campus, and the duration is approximately 4 hours. In addition to the practical exercise, students are required to submit a short essay answering a set of questions about their perception of public economics management at the local level. The objective of this written exercise is to promote a personal reflection on how their perception may have changed as a consequence of this simulation.

\subsubsection{Public Economics at the national level: National Parliament Simulation}

The second simulation focuses on the decision-making process at national level, and it consists of a simulation of the Congreso de los Diputados, the Spanish National Parliament. Students are randomly assigned to the different political groups represented at Parliament. Once the groups are formed, students work together to prepare a proposal regarding the topic of the debate, which is explained in a draft document proposed by the 
teacher and available at the moodle of the university. This document is always based on a topic from the real agenda of the parliament.

Each group has to submit a document explaining their position based on economic theory and the political position of the corresponding political parties. Then a general debate is celebrated, where each political group explains its initial position and debates with other groups through up to three spokespersons. This debate lasts for approximately two hours, and the document is voted in the last stage.

Since the goal of this simulation is to offer students an opportunity to experience a real parliamentary scenario, and to better understand the mechanisms underlying the decisionmaking process at the national level, the simulation may even finish without the required majority to pass the document. The main goal of this simulation is that students understand how difficult it may be to reach an agreement on Public Economics, when there may be conflicting positions between national and regional interests in a decentralized State.

\subsection{Public Economics at the international level: ECOFIN Simulation}

The third simulation focuses on the decision-making process at the international level and is organised into two different stages, entirely conducted in English. The first stage consists of two activities: (1) a theoretical session where the teacher summarises in English the concepts that students have studied in Spanish over the whole course, and (2) a set of presentations by researchers and professionals who work in EU-related topics. These interventions are held via videoconference and students are allowed to interact with the speakers.

The second stage consists of the simulation of a European Union institution, typically the Economic and Financial Affairs Council (ECOFIN), where students may participate representing the 28 Member States or the European Commissioner of Economic and Financial Affairs, Taxation and Customs. Students may participate individually or in groups of up to three people, depending on their command of English and public speaking skills in a foreign language. The teacher chooses a topic from the real ECOFIN's agenda. Then the student representing the Commissioner prepares a draft document which is distributed among the rest of students. Each student or group of students representing member States prepare a position paper explaining the position of each country as regards the proposed topic. This position paper is distributed among all students to help them to prepare the debate.

Then a debate is celebrated using a simple parliamentary procedure based on formal debate, moderated caucus and informal debate. Students explain their respective positions taking into consideration the real political and economic views of the countries they are representing. The last stage consists of voting on the draft document and its possible amendments presented by students. Again, the session may end without agreement, as the 
$1^{\text {ST }}$ INTERNATIONAL SCIENTIFIC CONFERENCE »TEACHING Methods FOR ECONOMICS AND BUSINESS SCIENCES«

J. Sierra: Simulations as a Teaching Method in Public Economics

objective of the simulation is to simulate a real parliamentary discussion ant thus it may be difficult to reach an agreement in about two hours.

Table 1: Specific skills developed through each simulation

\begin{tabular}{||c|c|c|}
\hline $\begin{array}{c}\text { Public Economics } \\
\text { Management Level }\end{array}$ & Simulation & $\begin{array}{c}\text { Specific Skills } \\
\text { Developed }\end{array}$ \\
\hline International & ECOFIN Simulation & $\begin{array}{c}\text { English command } \\
\text { Public speaking } \\
\text { Research skills } \\
\text { Negotiation skills } \\
\text { Time control }\end{array}$ \\
\hline National & Congreso de los & $\begin{array}{c}\text { Teamwork } \\
\text { Degotiation skills } \\
\text { Research skills }\end{array}$ \\
\hline Local & Parliament) & $\begin{array}{c}\text { Use of new technologies } \\
\text { Rapid-decision making }\end{array}$ \\
\hline
\end{tabular}

\section{Results of the pilot experience and implication for teaching practice}

These three simulations allow students to experience Public Economics decision-making process at different levels of public management in Spain. Impact on student education is evaluated through open surveys to assess to what extent their perception about the complexity of Public Economics management may have changed as a consequence of their experience. Results show that this method may contribute to an increase of students' engagement and motivation.

Students explain that participation in these three simulations has been useful to realise the importance of public sector intervention in the economy at all levels. They also highlight that these activities have helped them to better understand the different coexisting political and economic approaches. But the most important point is the recognition that after the first simulation they were much more motivated to fully benefit from the course on Public Economics and Tax System. This is a major achievement, as students' commitment has increased over time as well as their dedication to the weekly tasks, which consequently has resulted in higher participation and a better understanding of the course contents.

Students also explain that they have realised how difficult is for politicians to manage conflicting interests from different social groups, and to tackle the trade-off between short-term and long-term projects, always being aware of the constraints established by the political and economic cycle. They also argue that these practical framework is very useful to understand public sector's intervention in the economy as a whole, as the state that these three activities not only have been useful to understand the importance on the 
decision-making mechanisms at each level, but also how closely these three spheres are connected between them.

In addition to the open survey as regards their experience, an online survey was carried out at the end of the course to assess the usefulness for this project to help students to develop academic and research skills. This survey included a set of questions as regards the different skills inherent to the simulations. They argue that participating in these three practical activities has been very useful to develop several skills that may be of the utmost importance for their future academic and professional career. Students indicate that the five most valuable skills improved throughout the three activities are critical analysis of the real world, research skills, public speaking, team work and use of English. As regards the overall assessment of the simulations, $98 \%$ of participants consider these activities as very useful for their education and $96 \%$ would recommend future students to choose this practical teaching method within the framework of the course on Public Economics and Tax System.

From the teaching perspective, these three activities allow to tackle issues on the real agenda in a practical manner, providing a new insight to how to connect theoretical knowledge to real world problems. It has been very interesting to see how students have identified connections within the different public management levels, and how they explain economic, social and political positions demonstrating and adequate use of theoretical concepts and scientific terms. Nevertheless, the implementation of this project to all students enrolled in the course may be difficult because teacher monitoring may not be appropriate due to the large number of people enrolled.

This new teaching method will be implemented for the first time as a single pack within the course on Public Economics and Tax System during the academic year 2016 - 2017. Even though these three activities have been previously tested, this is the first year when these activities that are proposed as a single teaching and assessment method. The course has an approximate enrolment of 200 students, and the group is divided in three subgroups for the theoretical sessions and six sub-groups for the seminar sessions. Since it consists of a pilot project, students may choose whether to participate or not on the continuous assessment.

\section{Notes}

Students use Studium (the University of Salamanca Moodle) for submitting the weekly assignments and the book essay.

\section{References}

Babcock, P., \& Marks, M. (2011). The falling time cost of college: Evidence from half a century of time use data. Review of Economics and Statistics, 93(2), 468-78. doi:10.1162/REST_a_00093

Becker, W. E., \& Watts, M. (2001). Teaching economics at the start of the 21 st century. American Economic Review, 91(2), 446-51. doi:10.1257/aer.91.2.446 
J. Sierra: Simulations as a Teaching Method in Public Economics

Carter, L. K., \& Emerson T. L. N. (2012). In-class vs. online experiments: Is there a difference?. The Journal of Economic Education, 43(1), 4-18. doi:10.1080/00220485.2011.636699.

ENQA. 2015. Standards and guidelines for quality assurance in the European higher education area (ESG). Brussels: Belgium.

European Commission/EACEA/Eurydice. (2015). The European higher education area in 2015: Bologna process implementation report. doi:10.2797/128576.

Harter, C., Schaur G., \& Watts, M. (2015). School, department, and instructor determinants of teaching methods in undergraduate economics courses. Southern Economic Journal, 81(4), 1169-88. doi:10.4284/0038-4038-2013.266.

Lay Harter, C., Becker, W. E., \& Watts, M. (1999). Who teaches with more than chalk and talk. Eastern Economic Journal, 125(3), 343-356.

Watts, M., \& Schaur, G. (2011). Teaching and assessment methods in undergraduate economics: A fourth national quinquennial survey. The Journal of Economic Education, 42(3), 294-309. doi:10.1080/00220485.2011.581956. 



\title{
Innovations in the Sustainable Accounting Teaching Methods in Hungary - Best Practices
}

\author{
ÁGNES SIKLÓSI \& KRISZTINA SISA
}

\begin{abstract}
From time to time, one has to prepare for challenges in teaching accounting in higher education. They include varying expectations in the labour market, different attitudes and motivations of students, professional competence requirements, legal and business environments, the challenges of globalisation and, last but not least, the competition between universities. These factors all induce the need to become innovative. We are set to give an interpretation and a description of the concept of sustainable teaching of accounting in our study. We wish to provide a comprehensive view of teaching accounting in higher education institutions in Hungary. Our goal is to show the strengths and weaknesses of teaching accounting in higher education institutions of Hungary as well as the opportunities and threats that are found in teaching accounting in higher education institutions in a way that can innovate from time to time and is sustainable for many years.
\end{abstract}

Keywords: • tertiary education sector $\bullet$ accounting education $\bullet$ education methods $\bullet$ innovation $\bullet$ sustainability $\bullet$

Correspondence Addresses: Ágnes Siklósi, Ph.D., Associate Professor, Budapest Business School, Faculty of Finance and Accountancy, Buzogány utca 11-13, 1149 Budapest, Hungary, email: siklosi.agnes@uni-bge.hu. Krisztina Sisa, Ph.D., College Associate Professor, Budapest Business School, Faculty of Finance and Accountancy, Buzogány u. 10-12, 1149 Budapest, Hungary, e-mail: sisa.krisztina@uni-bge.hu. 

$100 \mid 1^{\text {ST }}$ International SCIENTIFIC CONFERENCE »TeACHING Methods For ECONOMics AND BUSINESS SCIENCES «

Á. Siklós \& K. Sisa: Innovations in the Sustainable Accounting Teaching Methods in Hungary - Best Practices

\section{Introduction - General features of Hungarian higher education system}

\subsection{Role of higher education in national economy}

Standing at the top of the education system, higher education specifically aims to improve quality of higher education par excellence to create a foundation necessary for acquiring and sharing competitive knowledge. Based on functional grouping of state related duties, the operation of higher education system is carried out as social welfare function of the state. Higher education - as opposed to public education - should not necessarily be provided exclusively within the public (re)production process, it is only an opportunity. In Hungary, the present form of higher education can be deemed as a mixed system, in which both state (tax) funding and self (private) funding exist parallel to each other, the latter entails a charge for customers engaging with higher education in form of a fee (service cost) to offset the value of provided service. The extent of state expenditures in education clearly indicates the involvement of the state in higher education, which can be best demonstrated by the ratio of education expenditures to GDP.

Table 1: Governmental education expenditures in Hungary 2001-2015

\begin{tabular}{|l|c|c|c||}
\hline Years & $\begin{array}{c}\text { GDP in current } \\
\text { prices, milliárd } \\
\text { HUF }\end{array}$ & $\begin{array}{c}\text { Total education } \\
\text { expenditures/GDP } \\
\text { \% }\end{array}$ & $\begin{array}{c}\text { Tertiary } \\
\text { expenditure } \\
\text { \% of GDP }\end{array}$ \\
\hline 2001 & 15383.4 & 5.01 & $1.05 \%$ \\
\hline 2002 & 17421.6 & 5.35 & $1.06 \%$ \\
\hline 2003 & 19077.3 & 5.62 & $1.13 \%$ \\
\hline 2004 & 21023.6 & 5.18 & $1.02 \%$ \\
\hline 2005 & 22470.8 & 5.21 & $1.01 \%$ \\
\hline 2006 & 24153.0 & 5.04 & $0.97 \%$ \\
\hline 2007 & 25560.4 & 4.81 & $0.99 \%$ \\
\hline 2008 & 27071.9 & 4.71 & $0.99 \%$ \\
\hline 2009 & 26297.4 & 4.70 & $1.00 \%$ \\
\hline 2010 & 27085.9 & 4.66 & $0.96 \%$ \\
\hline 2011 & 28166.1 & 4.30 & $0.96 \%$ \\
\hline 2012 & 28660.5 & 4.03 & $0.86 \%$ \\
\hline 2013 & 30127.3 & 3.79 & $0.81 \%$ \\
\hline 2014 & 32400.1 & 4.23 & $0.80 \%$ \\
\hline 2015 & 33999.0 & 4.35 & $0.78 \%$ \\
\hline
\end{tabular}

Source: KSH Statistics Hungary

International comparison helps to evaluate the level of public expenditures involved. 
Á. Siklós \& K. Sisa: Innovations in the Sustainable Accounting Teaching Methods in

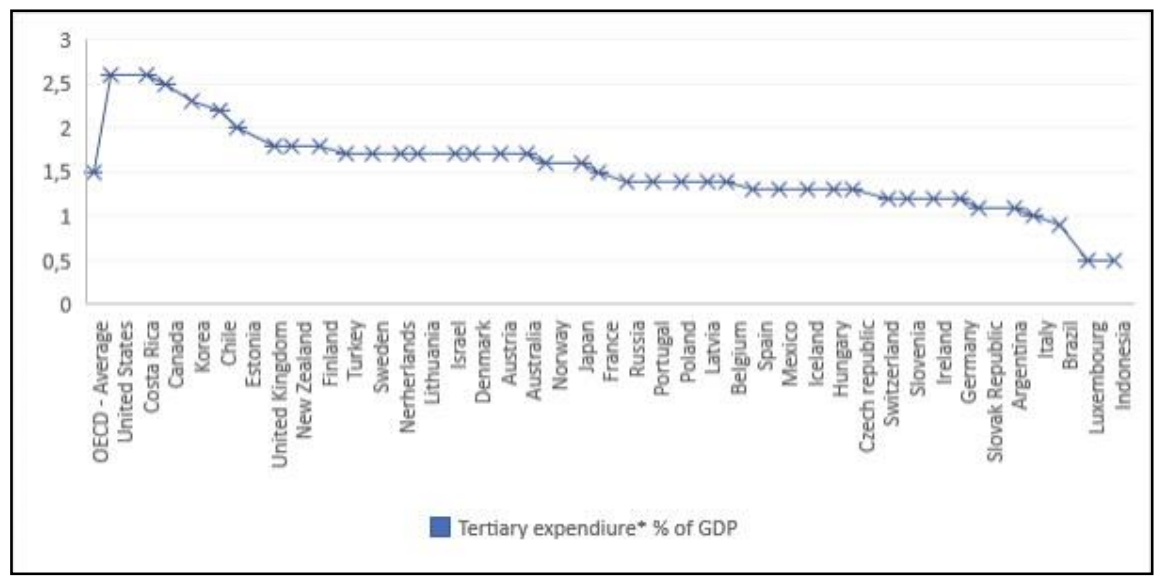

Figure 1: Education expenditure out of total GDP in international comparison-latest available (2014) (https://data.oecd.org/eduresource/education-spending.htm; OECD, latest available)

*Education spending covers expenditure on schools, universities and other public and private educational institutions. Spending includes instruction and ancillary services for students and families provided through educational institutions. Spending is shown as a percentage of GDP.

Among OECD member states, the latest data measured for higher education expenditures to GDP show an average of $1.50 \%$. Higher education expenditures in Hungary are below average, in the Visegrád Group however only Poland has a better result. In broader international comparison the picture is rather mixed. In Europe, with the ratio of $2 \%$ (expenditures to GDP) Estonia can be deemed as a country with the highest spending on higher education based on the OECD survey, while Luxembourg has the lowest value $(0.5 \%)$.

\subsection{Size and entities of the higher education sector}

Both the number of institutions and participating students in higher education clearly illustrates the size of the Hungarian higher education sector. 
$1^{\text {ST }}$ INTERNATIONAL SCIENTIFIC CONFERENCE »TEACHING Methods FOR ECONOMicS AND BUSINESS SCIENCES«

Á. Siklós \& K. Sisa: Innovations in the Sustainable Accounting Teaching Methods in Hungary - Best Practices

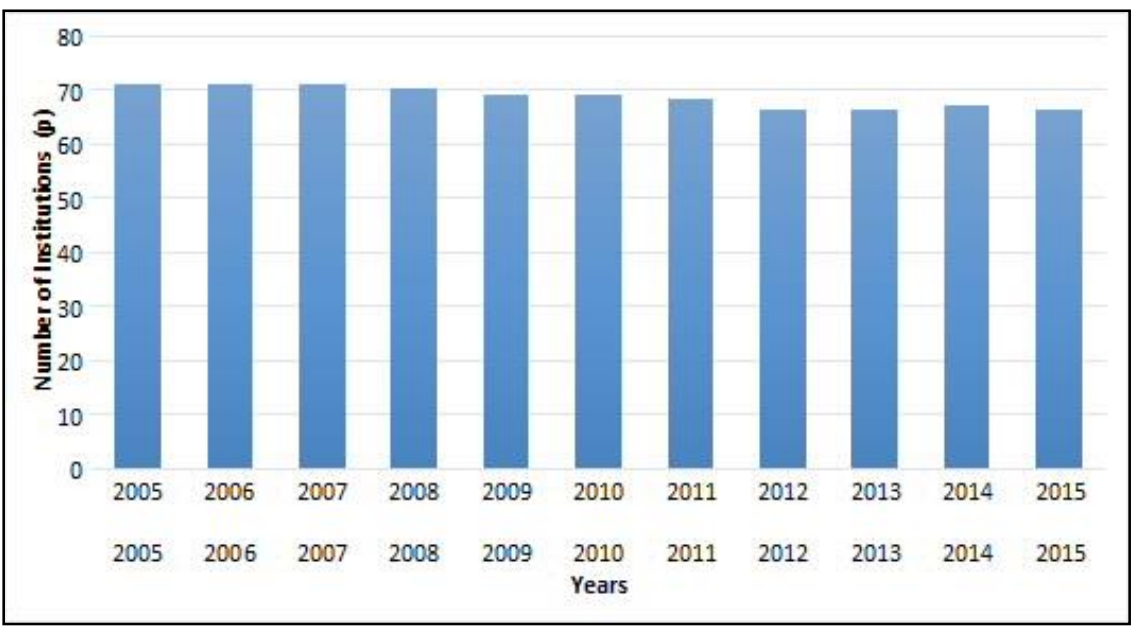

Figure 2: Number of Higher Education Institutions 2005-2015

At present in Hungary, 66 higher education institutions are offering various higher education programmes. Post-secondary vocational trainings, undergraduate (Bachelor's) and postgraduate (Master's) programmes and other postgraduate courses are appearing in the higher education mix as well. 17 of $\mathbf{6 6}$ institutions are running accounting and finance Bachelor's programmes, which represents $25.75 \%$ of the total number of institutions.

Table 2: Number of students in High Education

\begin{tabular}{|c|r|r|r|r||}
\hline \multirow{2}{*}{$\begin{array}{c}\text { Academic } \\
\text { year }\end{array}$} & \multicolumn{2}{|c|}{ Number of students } & \multicolumn{2}{c|}{ From full time students } \\
\cline { 2 - 5 } & Total & $\begin{array}{c}\text { of whom } \\
\text { full time: }\end{array}$ & in first grade & foreign students \\
\hline $2005 / 2006$ & 380632 & 217245 & 61898 & 10072 \\
\hline $2006 / 2007$ & 375819 & 224616 & 61231 & 10757 \\
\hline $2007 / 2008$ & 359391 & 227118 & 55789 & 11435 \\
\hline $2008 / 2009$ & 340851 & 224894 & 52755 & 12934 \\
\hline $2009 / 2010$ & 328075 & 222564 & 61948 & 14290 \\
\hline $2010 / 2011$ & 318019 & 218057 & 68715 & 15090 \\
\hline $2011 / 2012$ & 316385 & 218304 & 70954 & 16450 \\
\hline $2012 / 2013$ & 299636 & 214320 & 67014 & 17277 \\
\hline $2013 / 2014$ & 282296 & 209208 & 46931 & 20041 \\
\hline $2014 / 2015$ & 271480 & 203576 & 44867 & 21730 \\
\hline $2015 / 2016$ & 259529 & 195419 & \multicolumn{3}{c}{} \\
\hline \hline
\end{tabular}

Source: KSH Statistics Hungary (2016) 
Á. Siklós \& K. Sisa: Innovations in the Sustainable Accounting Teaching Methods in Hungary - Best Practices

Year by year, we can witness a continuous decreasing trend in the number of students participating in higher education. On the one hand, demographic reasons - parallel with continuously decreasing number of births - are standing behind the reduction; on the other hand, changes in the sector's funding system can be referred to. Changes in the funding system resulted in a substantially reduced quota for students participating in state-funded programmes, while the quota for self-financed students increased in parallel.

As a result, the above factors (being the relative high number of higher education institutions and decreasing number of potential students entitled for higher education) created a strong competition for participants in Hungary. The hunt for students is pushing institutions towards permanent reform and innovation. Nowadays institutions are appearing as service providers, where students can be identified as 'clients' engaging themselves in education.

\subsection{Budapest Business School}

\subsubsection{General introduction}

The Budapest Business School (formerly a college, which has been granted the "University of Applied Sciences" title on the $1^{\text {st }}$ January 2016) was established on the

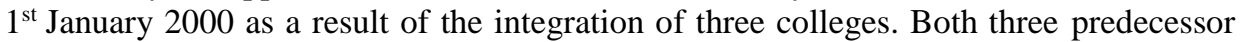
institutions possessed high education prestige, practical training of which was standing out in the country. After the integration Budapest Business School managed to retain and - in several areas - even to improve the quality of the education, and to increase the role of practical training. One of the results of such tenacious work was that the institution was among the first ones to receive the new classification for higher education institutions receiving the title 'University of Applied Sciences'. In 2013, the Institution obtained the title 'College of Applied Sciences' besides two other colleges to share this at the time. The university was among the first ones to create a dual education system in economics and informatics. The institution has continuously improved its activity in quality management, since 2013 it is holding the ISO 9001 quality management certification.

\subsubsection{Market position of BBS}

In recent years, the university was able to react to changes in higher education favourably, increasing the number of students in 2015 after initial drops in previous years. From the school year starting 2012 the government ceased to provide state-funding for education programmes in economics as a result of an education policy decision. As a consequence of this decision education programmes in economics are practically available in form of self-funding exclusively going forward. The indicative number of state-funded students is negligible compared to total education capacities. Despite all above funding for the institution is secured, any liquidity problems did not occur in recent years. 
$1^{\text {ST }}$ INTERNATIONAL SCIENTIFIC CONFERENCE »TEACHING METHOdS FOR ECONOMiCS AND BUSINESS SCIENCES«

Á. Siklós \& K. Sisa: Innovations in the Sustainable Accounting Teaching Methods in Hungary - Best Practices

Stable market position of BBS is mirrored by the number of applying and taken-up students at the university, which is clearly demonstrated in Figure 3. Despite some volatility the number of applying students indicates a multiple over-application in each year, substantially exceeding the potential limit of students according to our education capacities. On the whole, the university can fill the number of spaces available according to its capacities. Stable market position can be also granted by the diversified education portfolio of the BBS, as our Faculty is running several Bachelor's and Master's programmes. At the Faculty of Finance and Accountancy the education mix includes Bachelor's programmes, namely Finance and Accounting, Business Administration and Management, Human Resources and Business Information Technology, and Master's programmes, namely Accounting, Finance and Business Development.

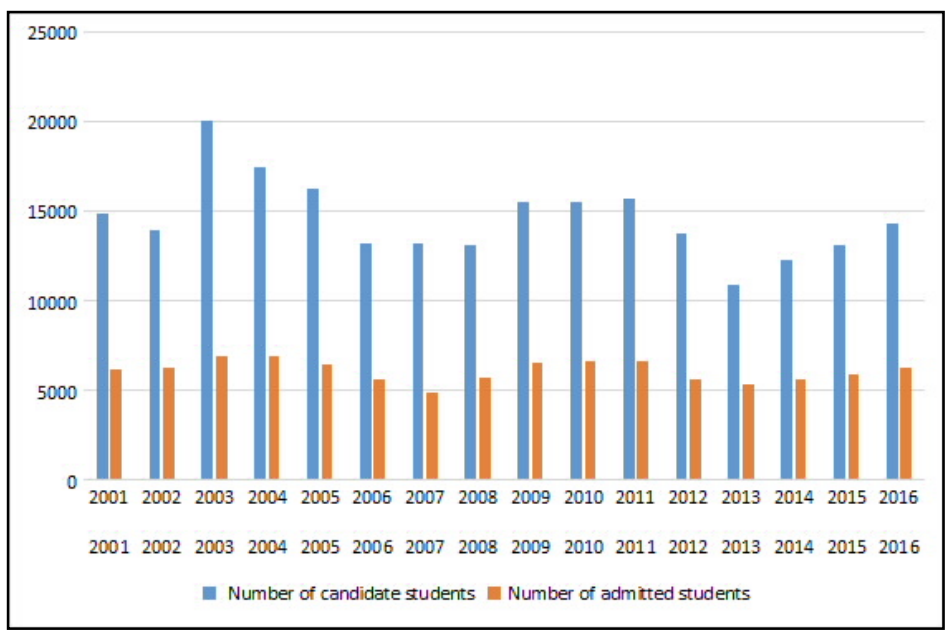

Figure 3: Number of candidates and successful admitted students in BBS between 20012016 years

Based on application statistics of recent years can be stated that most prospective students indicated an economic, engineering or pedagogic programme as priority among Bachelor's programmes. Business and management, nursery pedagogue and IT engineering (in order) proved to be the most popular undergraduate programmes. Beside IT engineering, also IT programme planning appears among the most popular Bachelor's programmes in the education area of informatics, the corresponding ones for engineering are mechanical engineer and electrical engineer. The Bachelor's programme named Finance and Accounting is ranked 9th based on the latest statistical data available. This ranking also indicates an attitude of the 'Generation $Z$ ' towards the profession of finance and accounting. 
$1^{\text {ST }}$ InTERNATIONAL SCIENTIFIC CONFERENCE »TEACHING METHODS FOR ECONOMICS AND

Á. Siklós \& K. Sisa: Innovations in the Sustainable Accounting Teaching Methods in Hungary - Best Practices

Table 3: The favourite academic institution attracting the top 14 first-place applications for undergraduate courses, and postgraduate courses starting September 2016

\begin{tabular}{|l|r|r||}
\hline \multicolumn{1}{|c|}{ Name of training } & $\begin{array}{c}\text { Number of first- } \\
\text { place applicants }\end{array}$ & Ranking \\
\hline \hline Business Administration and Management & 3879 & 1 \\
\hline Kindergarten teacher & 3145 & 2 \\
\hline IT-engineer & 3045 & 3 \\
\hline Mechanical engineer & 2974 & 4 \\
\hline Nursing and medical attendance & 2884 & 5 \\
\hline Psyhology & 2847 & 6 \\
\hline Tourism and catering & 2639 & 7 \\
\hline Commerce and marketing & 2431 & 8 \\
\hline Finance and accounting & $\mathbf{2 1 0 1}$ & $\mathbf{9}$ \\
\hline Infant educator & 2047 & 10 \\
\hline Program designer IT & 1955 & 11 \\
\hline Special education & 1703 & 12 \\
\hline Teacher & 1672 & 13 \\
\hline Electrical engineer & 1616 & 14 \\
\hline
\end{tabular}

BBS is continuously deepening its international integration. It is in an active relationship with professional organizations and higher education institutions abroad, and, additionally, it participates in international research projects.

Within this development process, the university aims to fulfil a more dominant position in regional-international higher education in business. Mission of BBS is to become a leading university of applied sciences in business in the education region of Central and Eastern Europe.

\section{Introduction of accounting education at BBS}

\subsection{Finance and Accounting Bachelor's and Master's Programmes at BBS}

Accounting training has a dominant and traditional role at the Faculty of Finance and Accountancy of the BBS. Accounting related courses appear in each programme in different thematic order and depth according to the specific needs of the programme.

In our study, the practice of accounting education will be introduced via the structure of the Finance and Accounting Bachelor's Programme and the succeeding Accounting Master's Programme, focusing on applied methods and their potentials, on the adaptation to changing environment and on the strengthened dimension of sustainability. 
$1^{\text {ST }}$ InTERnational SCIENTIFIC CONFERENCE $\gg$ TEACHING METHOdS FOR ECONOMICS AND BUSINESS SCIENCES «

Á. Siklós \& K. Sisa: Innovations in the Sustainable Accounting Teaching Methods in Hungary - Best Practices

Based on the system of education and the requirements, the number of credits to be collected to acquire the Bachelor's degree is $180+30$ credits. The Finance and Accounting Bachelor's Programme has a practice-oriented training structure, which means that about 60-70 per cent of total available credit can be collected via courses ending with a practical course mark. Minimum credit value of total extracurricular practical training: 30 credits, from which 10 credits are assigned to complete a thesis. Minimum credit value assigned to free choice courses: 10 credits.

\subsubsection{Educational goal of the Bachelor's Programme}

The educational aim of the Finance and Accounting Bachelor's Programme is to train finance and accounting professionals who possess up-to-date economic literacy complying with international requirements, theoretical and methodological knowledge for financial and accounting applications, who can produce and utilize the data representing the truth, who can increase knowledge capital as organizational asset, who can see through, operate and improve financial and accounting systems, who can make strategic decisions, who can apply up-to-date planning, management, settlement and controlling procedures and methods, who can shape organizational conditions, who can see through, operate information systems of international, national and regional enterprises, who can draw a position paper and make suggestions to achieve development objectives, who can coordinate negotiation processes and finally, who are prepared to continue studying in a Master's programme.

\subsubsection{Professional features}

Disciplines, specialties leading to the graduation, which the programme consists of:

- economic, methodological and business knowledge (mathematics, statistics, informatics, micro- and macroeconomics, international economics, finance, business economics, economic law, marketing, accounting, management, business communication, business language, environmental-economics, another business courses) 80-90 credits;

- knowledge of social sciences (European Union, general and economic law, economic history, sociology, philosophy,) 10-20 credits;

- professional knowledge related to finance and accounting (finance, law, financial calculations and financial markets, taxation, enterprise evaluation, financial accounting, basics of management accounting, methodologies for analysis and control, business planning, financial and accounting informatics, training for special accounting cases, and more free choice specializations) 7090 credits. 
Á. Siklós \& K. Sisa: Innovations in the Sustainable Accounting Teaching Methods in Hungary - Best Practices

Up to maximum of 30 credits, special knowledge can be acquired in professional areas complying with the requirements of the broader finance and accounting profession within the whole programme.

In the Finance and Accounting Bachelor's Programme, in full-time training following courses are obligatory:

$1^{\text {st }}$ semester: Introduction to Accounting (2+2), 5 credits, practical course mark;

$2^{\text {nd }}$ semester: Financial Accounting 1. (2+3), 6 credits, practical course mark;

$3^{\text {rd }}$ semester: Financial Accounting 2. (2+2), 5 credits, exam;

$4^{\text {th }}$ semester: Management Accounting (2+2), 5 credits, practical course mark;

$5^{\text {th }}$ semester: Accounting Specialties $(1+1), 3$ credits, practical course mark;

$6^{\text {th }}$ semester: Basics of Concern Accounting (1+1), 2 credits, exam and

International Accounting Lessons (1+1), 3 credits, practical course mark

Free choice courses: Non-profit Accounting, Accounting and Controlling in

Computerized Environment, Accounting in Credit Institutions.

In the $5^{\text {th }}$ and $6^{\text {th }}$ semester, beside purely accounting related courses, there is a huge emphasis on teaching curriculum materials based on accounting information systems, such as Complex Analysis, Performance and Resource Analysis, Business Planning, Basics of Auditing and Controlling.

Accounting course structure of the full time Accounting Master's programme (being the second level of the education) is as follows:

$1^{\text {st }}$ semester: Advanced Financial Accounting (2+2), 5 credits, practical course mark;

$2^{\text {nd }}$ semester: Advanced Management Accounting (2+2), 5 credits, practical course mark, Creation and Analysis of a Consolidated report (2+2), 5 credits, exam; $3^{\text {rd }}$ semester: IFRS (2+2), 5 credits, practical course mark, Accounting and Control of Credit Institutions $(2+2), 5$ credits, practical course mark, Accounting Regulation (2+2), 5 credits, exam;

$4^{\text {th }}$ semester: Accounting of Financial Instruments $(2+2), 5$ credit, practical course mark.

\subsubsection{Specializations in the Accounting Master's programme}

Specializations in this programme are:

- Control and Audit Specialization: one of the key topics of the specialization is the audit and control, which entails two-semester training. This is closely linked to a course named „Computerized Audit Support”, which emphasizes the practical aspects of audit activity, analysing concrete case studies with help of audit software. 
$1^{\text {ST }}$ InTERnATIONAL SCIENTIFIC CONFERENCE $»$ TeACHING METHOdS FOR ECONOMICS AND BUSINESS SCIENCES «

Á. Siklós \& K. Sisa: Innovations in the Sustainable Accounting Teaching Methods in Hungary - Best Practices

- Management Accounting Specialization: Main topics of the specialization are introduced in the courses of „Strategic Management Accounting” and „Cost and Performance Accounting”. Additionally, the courses of „Accounting Theory and Research”, „Computerized Accounting Support” and „Accounting Case Studies" also provide a lot of useful knowledge applicable at practice as well.

\subsection{Statistics of BBS-FFA Finance and Accounting Bachelor's Programme}

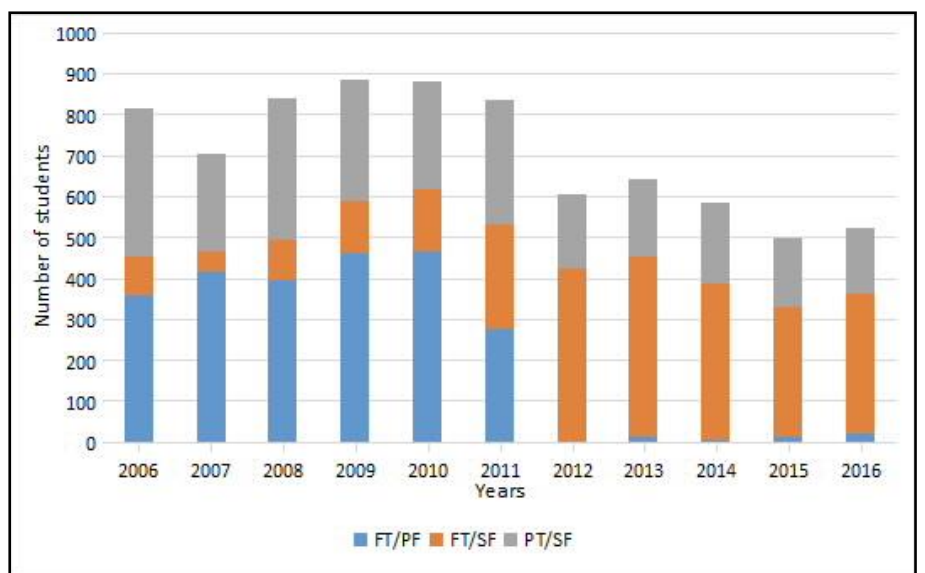

Figure 4: Number of admitted students at BBS Faculty of Finance and Accounting finance and accounting basic course between 2006 and 2016

\section{Supplementary information:}

FT/PF: full time publicly funded FT/SF: full time self -financing PT/SF: part time self-financing 
Á. Siklós \& K. Sisa: Innovations in the Sustainable Accounting Teaching Methods in

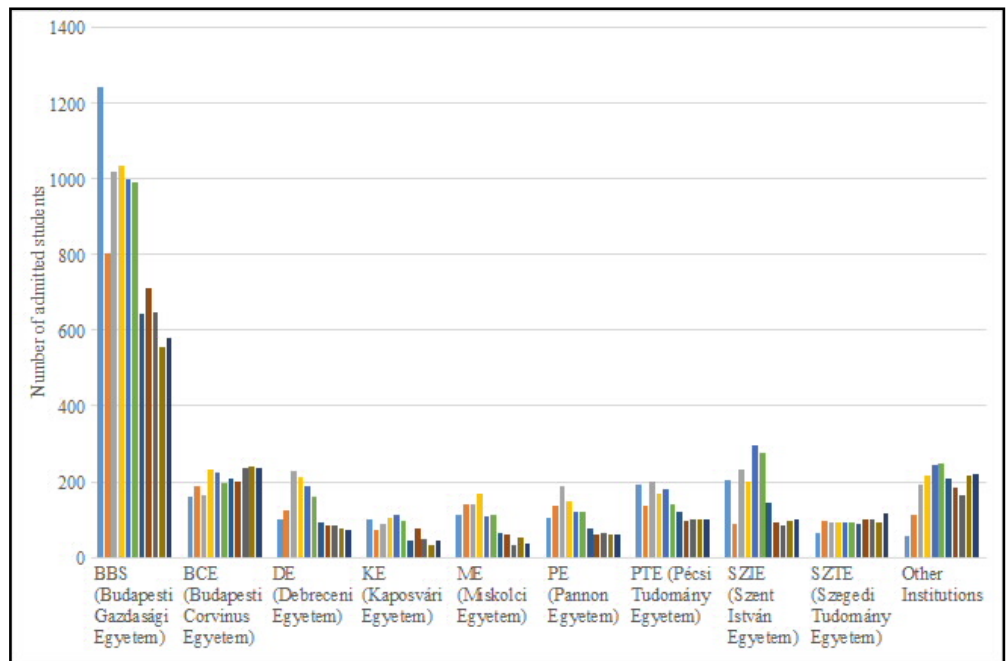

Figure 5: Number of students admitted to financial and accounting undergraduate students between 2006 and 2016

Today in Hungary, 17 institutions are running finance and accounting Bachelor's programmes $^{1}$. Data presented in the table show number of students taken up for both fulltime and part-time education in the last 11 years. BBS has a leading role in this education segment. In 2016 it had a market share of $37 \%$, in the whole period it moved around $40 \%$. One of the reasons for the decline is the high number of new entrants on the market, as a consequence of which the education of accounting and finance has become pretty much fragmented.

The accounting Master's programmes (linked to finance and accounting Bachelor's programmes) represent a much smaller market. Altogether 7 institutions are running such programmes, mostly in both full time and distance learning, but some are offering either full time or distance learning exclusively. Almost everywhere, programmes start both in the September semester and in the February cross-semester. In several cases, this can challenge the rentability of the education programme. 
$1^{\text {ST }}$ INTERNATIONAL SCIENTIFIC CONFERENCE $»$ TeACHING METHODS FOR ECONOMICS AND BUSINESS SCIENCES «

Á. Siklós \& K. Sisa: Innovations in the Sustainable Accounting Teaching Methods in Hungary - Best Practices

Table 4: Number of students admitted to accounting Master's course in Hungary depending by course (full-time or part-time) between 2009-2016

\begin{tabular}{|l|r|r|r|}
\hline Years & Full-time & Part-time & \multicolumn{1}{|c|}{ Total } \\
\hline 2009 & 16 & 127 & $\mathbf{1 4 3}$ \\
\hline 2010 & 188 & 189 & $\mathbf{3 7 7}$ \\
\hline 2011 & 190 & 200 & $\mathbf{3 9 0}$ \\
\hline 2012 & 143 & 202 & $\mathbf{3 4 5}$ \\
\hline 2013 & 118 & 218 & $\mathbf{3 3 6}$ \\
\hline 2014 & 125 & 256 & $\mathbf{3 8 1}$ \\
\hline 2015 & 129 & 243 & $\mathbf{3 7 2}$ \\
\hline 2016 & 110 & 244 & $\mathbf{3 5 4}$ \\
\hline
\end{tabular}

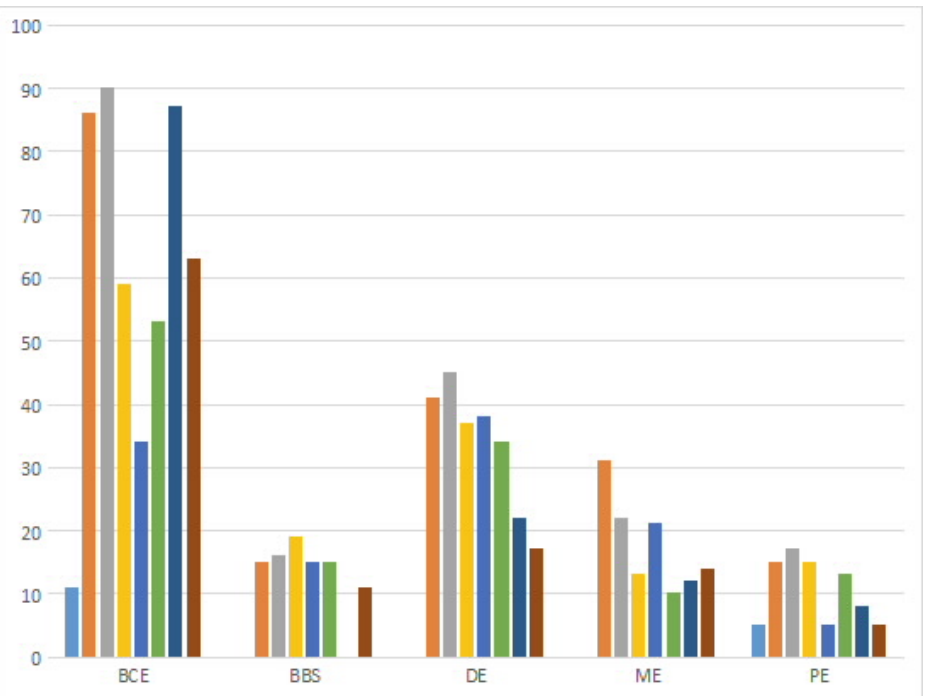

Figure 6: Number of students admitted to accounting Master's course in Hungary fulltime between 2009-2016

Figure 6 shows the number of students taken up for accounting Master's programme by institutions. Corvinus University of Budapest is the market leader within this segment. Application statistics show a high volatility for each institution in the corresponding period. Figure 7 shows the number of students taken up for distance learning, summarizing the data for both the September semester and the February cross-semester. Within this segment, BUTE and BBS are the market leaders. 
Á. Siklós \& K. Sisa: Innovations in the Sustainable Accounting Teaching Methods in Hungary - Best Practices

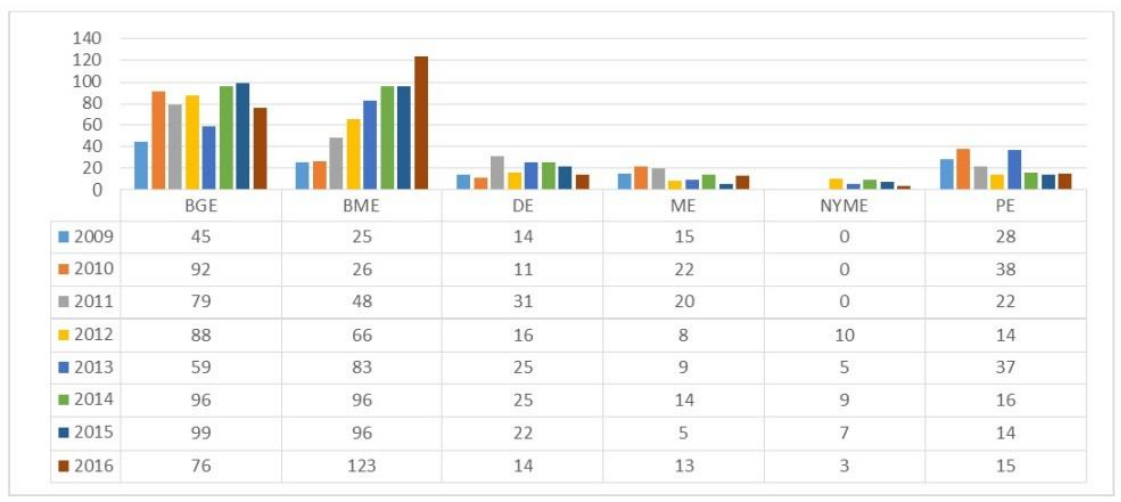

Figure 7: Number of students admitted to accounting Master's course in Hungary parttime (distance learning) between 2009-2016

\section{Teaching methodologies in the segment of BBS accounting education}

Teaching methodologies ".... are permanent and repetitive constituents of the teaching process, parts of the activities of the tutor and the student, which are applied organized in distinct strategies in order to achieve different goals" (Falus, 1999, p. 283).Mostly traditional teaching methods are applied during introductory courses in the Bachelor's Programme, beside casual application of their corresponding electronic forms. In the $5^{\text {th }}$ and $6^{\text {th }}$ semester, there is more room for interactive methods to be applied in smaller groups of students, but these will become more significant mainly in Master's programmes.

Among traditional teaching methods the following will be applied: lecture, explanation, recital, student presentation, discussion, debate, demonstration, project method, cooperative teaching, simulation, role play and game.

Among electronic correspondents of the methods above, webinar, podcast, chat, post, comment are used in our institution. Collaborative solutions suitable for online cooperation make the project method applicable, framework systems (CooSpace, Moodle) help to use cooperative teaching, (demo versions of relevant) software creates simulations.

Lectures are necessary, but the efficiency of a 90 minute lecture is unfortunately very low. It only helps the simple knowledge transfer, when the lecturer is able to keep the attention of the audience. Lecturers are typically using the method of power-point based slide projection, where we are trying to ease the acquisition of the material by using practical examples and spectacularization. In the near future, we intend to introduce a mobile application during the lectures, in which the student should face a test question approximately every 10-15 minutes to provide feedback on what is understood. The lecturer would get prompt results and would be able to decide whether to further proceed 
$1^{\text {ST }}$ INTERNATIONAL SCIENTIFIC CONFERENCE »TEACHING Methods FOR ECONOMicS AND BUSINESS SCIENCES«

Á. Siklós \& K. Sisa: Innovations in the Sustainable Accounting Teaching Methods in Hungary - Best Practices

with the material or another explanation is needed. This method can also be suitable to keep the attention and to measure the presence of the students, to control understanding of the part of the material just shared. Besides, it plugs the student into the flow of the lecture, it motivates for active participation through electronic tools embedded in their everyday life. Tests aiming to measure understanding of the material can be very varied, and should not necessarily be limited to multiple choice or true/false questions.

Due to changes in secondary education, the duration of classes was reduced to 30 from 45 minutes, taking into consideration the concentration ability and capacity of children in the age of elementary school. It should also be considered to reduce lecture duration to 60 from 90 minutes in case of accounting related courses. Justification of the above should be partly rooted in the concentration ability of today's 'Generation Z', the other factor is the complexity and hard-to-understand nature of accounting topics and profession. It is a huge challenge to continuously keep the attention of students in case of accounting related courses. The majority of the students get stuck early in the process of understanding, which also hampers the prolonged teaching and the presentation of explanations and connections.

The most common concept of traditional role of the tutor is the knowledge sharing mentality, the essence of which is the thorough and professional presentation of knowledge by the tutor. Besides (or even prior to) knowledge sharing, tutors are recently expected to provide a mentoring and constructivist attitude, which lays emphasis on the evolution of student's personality even at the expense of material knowledge share but assisting the student to unfold his/her potentials. To be able to do this, the tutor should possess adequate material and professional knowledge, good lecturing skills and the necessary attitudes for teaching. All this obviously means that outstanding professional knowledge of the tutor is not sufficient in higher education either, because the activity would also entail taking care of the student and a pedagogic attitude. There is much room to improve this area. Besides professional training, we also place emphasis on pedagogic training, getting familiar with up to date teaching methodologies.

Thus, in the area of teaching methodologies a paradigm shift is necessary. Education of the present generation via traditional methods exclusively does not necessarily lead to the success expected. Achievements of the modern world should be partly or wholly integrated into the education, the interest and attention of students should be kept through these instruments. The issue of under-motivation of students is really complex, but this is obviously an effect of mass education at higher level. Students reaching higher education are less motivated on the whole in case of the programme selected by themselves or possibly under pressure by the parents. In many cases they are not even aware of the content of the programme, their future prospects for more studying or on the job market, as numerous new programmes are continuously appearing under various labelling, occasionally with minimum differences in the very content.

At present in Hungary, natural sciences and different areas of engineering are priorities in terms of government education policies. As a consequence of the ongoing reform in 
Á. Siklós \& K. Sisa: Innovations in the Sustainable Accounting Teaching Methods in Hungary - Best Practices

primary and secondary education also the knowledge of graduates varies much more compared to previous period. In many cases higher education is forced to share knowledge not provided in public education, therefore even less time can be taken to transmit the learning material of the core programme.

We place the importance to individual efforts of students to be able to reach suitable competencies. Extracurricular processing of learning materials and other professional activities provide a substantial contribution for the student to be able to orientate themselves in the world of mass information:

- prioritize between pieces information of different level of importance;

- see through problems, nexus of the subject; and

- form own opinions, an through this to acquire basics of scientific thinking.

To achieve these goals, the tutor:

- gives tasks for successful seminars and practical courses;

- gets the students to write essays, to make presentations and evaluate them together;

- gets the students to read the most recent studies, actualities of the subject in domestic and foreign language;

- encourages the students for cooperative work in small groups along processing case studies;

- tries to invite professional organizations, corporate partners for a couple of lessons to transmit a practical approach of the actual learning material, and to bring science closer to life; and

- gives opportunities for fieldwork and site visits to enable close observation of the processes and methods learned.

The acquisition of practical knowledge plays a significant role in the teaching programme of Finance and Accounting Bachelor's Programme, which materializes during the programme in various forms and is linked to different parts of the theoretic material attainment. Practical training includes the following elements:

- 4 week professional practice in the summer after the $4^{\text {th }}$ semester;

- office practice for students participating in Accounting Master's programme;

- 13 week professional practice in full time training in $6^{\text {th }}$ semester of the programme;

- 13 week professional practice aiming to acquire practical experience required in distance learning in form described later;

- minimum of 13 consecutive weeks of professional practice after the $4^{\text {th }}$ active semester in distance learning. 
$1^{\text {ST }}$ INTERNATIONAL SCIENTIFIC CONFERENCE »TEACHING Methods FOR ECONOMicS AND BUSINESS SCIENCES«

Á. Siklós \& K. Sisa: Innovations in the Sustainable Accounting Teaching Methods in Hungary - Best Practices

We would like to highlight office practice. The goal of office practice for students of the Finance and Accounting Bachelor's Programme is to integrate theoretical knowledge acquired after passing on 'Financial Accounting 1' course into performing practical tasks, and to get familiar with economic environment of enterprises. During office practice activities (starting in each semester), participants get acquainted with the practice of enterprise formation, with the structure of accounting software, with the accounting of certain original documents, with the completion of different tax returns and with the routines of accounts closure and report making. Based on practical knowledge acquired during office practice, the student will be able to independently carry out accounting services for small- and medium-sized enterprises.

A key challenge of today is that beside the need for lifelong learning, employees are facing new expectations at workplaces during teamwork, i.e. the difficulties of carrying out an activity in a defined group, which our education system does not really prepare us for.

Teamwork is an activity which can be carried out in seminars in higher education, inter alia through creating case studies, project works, which strengthens students' competencies of contact making, cooperation, prioritization, creativity and forming an opinion. Here, training participants perform the task collectively in smaller groups of 2-5 individuals, which is followed by a presentation of the results, which is discussed in a chat or possibly in a debate.

Work of the group is managed by the members themselves; they create the framework for cooperation, which they later need to comply with. This is one of the best ways for learning by experience, because:

- own defined tasks should be performed,

- results should be presented, and

- performance of both own and other groups should be analysed.

In accounting education, teamwork is mainly applied in the Master's Programme or during courses of higher years in the Bachelor's Programme.

In the case of basic courses, we provide support for the preparation in form of e-learning materials beside traditional lectures and seminars, and other online sources including examples help the student to acquire the knowledge.

We place an emphasis on continuous rejuvenation of the programme, to restore the prestige of the accounting profession, and to increase the popularity of the accounting career path. A key point of this is to maintain intensive relationship with prominent representatives of the profession, through which we do not only get informed of professional requirements in case of graduates, but they integrate themselves into the 
Á. Siklós \& K. Sisa: Innovations in the Sustainable Accounting Teaching Methods in Hungary - Best Practices

education, they bring 'reality' into lecture and seminar rooms by introducing some career opportunities as well.

In our opinion, the biggest opportunity (for students) of recent years is that accounting trainings can also be held within the cooperation involving the Big 4 and another mediumsized accounting and audit advisory companies. In the course of this cooperation, interested students can attend a 4-to-6 week series of lectures and seminars. The training ends with professional test-writing, where companies are offering concrete job positions and internship programmes to students achieving the best results.

Developments of teaching methodologies should have an answer for new challenges of our era conforming to the needs of 'Generation Z', raising their interest, keeping their motivation. For this, a change is needed in the attitude of the tutors as well. This requires a paradigm shift beside infrastructural developments.

\section{$4 \quad$ SWOT analysis of higher education in accounting}

Based on statistical data and teaching experience discussed in the study, the strengths and weaknesses can be outlined for the Hungarian higher education in accounting.

Table 5: SWOT analysis of higher education in accounting

\begin{tabular}{|l|}
\hline External conditions, barriers \\
$\quad \square$ (shortfall of) state-funding \\
$\quad$ highest number of Bachelor's programmes in the country with permission \\
$\quad$ (extremely high competition) \\
\hline Strengths: \\
Students: \\
$\square$ our programme has the highest recognition among all accredited finance and \\
$\quad$ accounting Bachelor's programmes in higher education institutions of the \\
$\quad$ country \\
$\square$ students' involvement in departmental research activity \\
$\square$ special post-secondary training to provide the preparation for the Bachelor's \\
programme \\
$\square$ students' involvement in departmental professional programmes \\
$\square$ opportunity to progress towards a postgraduate programme (Finance and \\
Accounting Master's Programme) \\
Tutors: \\
$\square$ qualified, recognized tutors in the profession \\
$\square$ own educated tutors \\
$\square$ favourable age combination of tutors \\
$\square$ regular publications in scientific journals \\
$\square$ majority of our tutors are certified auditors \\
$\square$ our tutors are authors of country-wide used professional literature \\
\hline
\end{tabular}


$1^{\text {ST }}$ INTERNATIONAL SCIENTIFIC CONFERENCE $\gg$ TEACHING METHOdS FOR ECONOMICS AND BUSINESS SCIENCES «

Á. Siklós \& K. Sisa: Innovations in the Sustainable Accounting Teaching Methods in Hungary - Best Practices

$\square$ part of our tutors regularly participate in certified accounting trainings (as a tutor), in annual trainings for accountants and in the creation of the related professional literature

collective research and publication opportunities

$\square$ innovative management

Market:

country-wide recognized professional headquarters

permanent representation of the department in vocational and other trainings and exams organized by the Faculty

extensive domestic and foreign corporate relationships (primarily with 'BIG4' companies)

cooperation with the Chamber of Hungarian Auditors (providing internship programmes for students facilitated by the Chamber) and another professional organizations (Management and Controlling Association, Organization for Hungarian Accounting Professionals)

good job opportunities, attractive starting salaries

Teaching, developing learning materials:

professionally recognized guest tutors

e-learning materials supported by video-lectures for accounting courses

strong financial, accounting background

\section{Weaknesses}

Students:

$\square$ large group seminars even in case of courses demanding small group work

Tutors:

$\square$ rate of certified tutors should be further increased

Market:

only a few tutors participate in the training of auditors

Teaching, developing learning materials:

development of e-learning materials in case of controlling courses

full integration of research work into learning materials

system of student control (less opportunities for oral exams due to high number of students)

dominant frontal teaching methodologies

\section{Development, improvement opportunities}

Students:

$\square$ chance of the involvement of students into real corporate projects beyond professional practice

making office training opportunities available for all students in Finance and Accounting Bachelor's Programme

students' involvement in departmental research work in more organized manner increasing number of foreign language programmes, opportunity to acquire a 'dual diploma' through integration into the education of foreign peer universities

Tutors:

improvement of organization of the departmental research activity 
Á. Siklós \& K. Sisa: Innovations in the Sustainable Accounting Teaching Methods in Hungary - Best Practices

$\square$ strengthening international publication potential via departmental and international co-operations

Market:

shaping certain courses to reflect market needs related to other Bachelor's programmes

permanent consultation with market participants of development opportunities

Teaching, developing learning materials:

strengthening international relationships

starting joint projects with the other three departments belonging to our Faculty (Business Informatics, Business Administration and Management and Human Resources)

modernization and computer-supported presentation methods for the part of management accounting and controlling related courses according to current market expectations

introduction of dual education

\section{Threats}

Students:

$\square$ continuous decrease of students' interest for concrete professional knowledge departmental (tutor) resource limits for thesis-discussion

Tutors:

drop in teaching quality due to continuous publication expectations and too heavy tutor workload

Market:

departmental (tutor) resource limits for thesis-discussion

$\square$ large number of competitors

self-funding education form

decreasing level of interest towards accounting career in both domestic and international dimension

Teaching, developing learning materials:

$\square$ decreasing popularity of traditional professional literature, as students demand more colourful, bright and playful electronic learning materials

\section{Summary}

In our study we summarized the features, currently applied teaching methods and development opportunities for higher education in accounting of the Budapest Business School. As for a résumé, we make an attempt to define sustainable higher education in accounting. In our understanding, sustainable higher education in accounting is a flexible and open education system which is able to continuously rejuvenate itself, timeously reacting to market challenges, students' motivation and competencies. Openness means an intensive relationship with the profession, which is of utmost importance, since this ensures the prompt integration of up to date practical applications into the teaching process. 
$1^{\text {ST }}$ InTERnational SCIENTIFic CONFERENCE »TEACHING METHOdS FOR ECONOMics AND BUSINESS SCIENCES«

Á. Siklós \& K. Sisa: Innovations in the Sustainable Accounting Teaching Methods in Hungary - Best Practices

\section{Notes}

Other institutions not named in the table are as follows: BUTE, BMU, EKU, UWH, PAU, TPC, WBS, KSU. The table is created based on all data available of each faculty and education department of the corresponding institutions.

\section{References}

BGE (2016). BGE intézményfejlesztési terve. Retrieved from https://www.unibge.hu/documents/SZABALYOZO_DOKUMENTUMOK/05szervezeti_es_mukodesi_rend/SZMR_ME LLEKLET/24.-szamu-A-Budapesti-Gazdasagi-Egyetem-Intezmenyfejlesztesi-terve-(hatalyos-2016.marcius-18.-napjatol)/BGE_IFT_alairt.pdf

OECD. (2016). Public spending on education. Retrieved March 3, 2017, from https://data.oecd.org/eduresource/education-spending.htm

KSH. (n.d.). Education statistics of Hungary. Retrieved from https://www.ksh.hu/docs/hun/xstadat/xstadat_eves/i_zoi008.html

Falus, I. (Ed.) (1999) Didaktika (Második javított kiadás). Budapest: Nemzeti Tankönyvkiadó. 


\title{
Using Business Simulation Methodologies in Higher Education: Lessons Learned
}

\author{
PAULINO SILVA
}

\begin{abstract}
This paper presents the lessons learned with the inclusion of Business Simulation courses in the Accounting and Administration undergraduate degree at ISCAP - IPP (School of Accounting and Administration of Polytechnic Institute of Porto). These courses were introduced in the beginning of 2003 with a main purpose: to provide students a risk-free simulated business environment to prepare them for a very demanding real business world and be an alternative to the internship in a real company for those who wanted to be certified accountants. During the two semesters students perform the role of general managers. All the activities provided to students have a connection with previous knowledge they acquired in other courses of the degree. Business Simulation courses enabled a smoother transition to the business world, which demands a more action-based education. In this line, and besides technical skills, some soft skills are also promoted, such as critical thinking, collaboration and communication.
\end{abstract}

Keywords: • business simulation • learning methodologies $\bullet$ action-based learning $\bullet$ practical education $\bullet$ knowledge integration $\bullet$

Correspondence Address: Paulino Silva, Ph.D., Assistant Professor, Instituto Superior de Contabilidade e Administracao do Porto, Politécnico Do Porto, R. Jaime Lopes Amorim s/n, 4465004 Matosinhos, Portugal, e-mail: paulino@iscap.ipp.pt. 
$1^{\text {ST }}$ InTERnATIONAL SCIENTIFIC CONFERENCE $\gg$ TEACHING METHOdS FOR ECONOMICS AND BUSINESS SCIENCES «

P. Silva: Using Business Simulation Methodologies in Higher Education: Lessons Learned

\section{Introduction}

In February 2003, Business Simulation (BS) courses were introduced in the accounting and administration degree at ISCAP-IPP. There was a special context for the emergence of BS courses. First, future certified accountants need a practical course or an internship to access to the profession. Second, it was important to change the traditional role of accountants as bookkeepers and enhance them as members of the decision team within a company. Third, accounting and business education at ISCAP become too theoretical over the previous years, and there was no opportunity for students to apply in practice theoretical knowledge from other courses. Recognizing that students were not totally prepared for the real business life, the institution decided to change and introduced BS courses in the accounting and administration degree. For this change a huge investment was needed. Facilities such as computers, servers, printers, telephones, scanners and other office material were provided. Additionally, ERP software was also purchased and implemented to give the students a very close picture of the most technologically advanced business world. Contracts for new teachers and assistants with specific training were provided.

This article is organized as follows. After the introduction we present a brief literature review. The third section presents the methodology and field study. In the fourth section we present lessons learned and conclusion.

\section{Brief literature review}

With the strong proliferation of new information technologies, the problems of scarcity and access to the information had diminished dramatically. Knowing how to filter information became an essential skill in a market in which economic agents are more and more competitive. This trend reinforces the importance of the accountant in the organization's life: The accountant is, and always was, responsible for the preparation of financial and economic information. However, as a result of a more complex business world, translated into new technologies, more demanding customers, more competitive markets, etc., the accountant's job became more complex as well. The accountant of today is also a manager, a member of the decision-making team. He needs to capture and analyse, not only internal information, but also external information.

In this line, it is recognized that business-related professions are constantly subject to change, not only in Portugal but also in the rest of the world. The accountant and the manager need to adapt themselves in a continuous way to face these changes. To be good professionals they need diversified skills and competencies. For example, the International Accounting Education Standards Board (IAESB), in the Handbook of International Education 2014, defined different types of skills for an accounting student: technical competence, professional skills, and professional values, ethics, and attitudes (IAESB, 2014). Also, the International Federation of Accountants (IFAC) defined some guidelines for the education of the future professionals, such as intellectual skills, technical and functional skills, personal skills, interpersonal and communication skills 
P. Silva: Using Business Simulation Methodologies in Higher Education: Lessons

Learned

and management, organizational and education skills (IFAC, 2010). To meet these purposes and for a better integration into the labour market, it is recognized that accounting and business education should include a practical component. Adler and Milne (1997) argue that problem-based and peer-assisted learning tasks can help to improve several skills desired by professions and employers (Adler \& Milne, 1997). Around the world, there are some research experiences that found the need of change in business education areas. Lin et al. (2005) found that professionals, educators and students were dissatisfied with the way knowledge was delivered to accounting students. In this line, and as accounting education was too theoretical the researchers argue a need of a reform in Chinese accounting education (Lin, Xiong, \& Liu, 2005).

Methodology and Field Study

In this paper, we used a descriptive and exploratory case study. It is possible to understand the context and have a holistic view of the BS experience using this research methodology. Some informal interviews were also conducted among the teachers and students to collect feedback about the methodology and the whole system that was put in place and is still working.

ISCAP-IPP is a business school, part of one of the largest higher education institutions in Portugal - the Polytechnic Institute of Porto. Today, the school has more than four thousand students, almost three hundred teachers. Undergraduate degrees and master degrees are offered in the business areas. The BS project is associated with the undergraduate degree of accounting and administration. In this degree there are students with some work experience and without any work experience, which means heterogeneity of students. The implementation of BS courses in February 2003 had two main goals: prepare students to access the Order of Chartered Accountants (OCC); and improve business education methodologies to meet the requirements of the challenging business world. BS courses are a response not to a distant future, but to a nowadays challenge. Students are submitted to an experience that sometimes is more demanding than the one they will find in the real business world. So, a new paradigm of education was put in place. Some traditional lectures with lots of theoretical contents that have, in some cases, a boring effect among students, were substituted by practical classes in which students learn by doing. BS courses are the opportunity students had to put in practice their theoretical knowledge. Additionally, students had the opportunity to use an integrated management system (ERP - Enterprise Resource Planning) to manage all proposed activities in a business context. In order to give the students an idea about the external market and its impact on their businesses, there is an activity that consists of picking real news from media that should be related with their own company that should be commented and analysed. To set up a company with the needed legal procedures and to transform it into a public company are just other examples of the main complexity students find in BS courses. 
$1^{\text {ST }}$ InTERnational Scientific CONFEREnCE $\gg$ Teaching Methods For ECONOMics AND BUSINESS SCIENCES «

P. Silva: Using Business Simulation Methodologies in Higher Education: Lessons Learned

More concrete, here we enumerate some examples of activities and topics developed in BS courses:

- Set up the company: legal, fiscal and accounting procedures,

- Preparation of sales contracts,

- Preparation of purchase contracts,

- Preparation of invoices,

- Payroll management,

- Preparation of royalties' contracts,

- Preparation of leasing contracts,

- Preparation of factoring contracts,

- Inventory management,

- Financial accounting entries,

- Cost accounting systems,

- Management accounting,

- Cash flows management,

- Cost-volume-profit analysis,

- Balance sheet and income statement,

- Preparation of tax declarations,

- Preparation of reports,

- Oral presentations.

\subsection{Resources}

At the beginning, more than ten teachers and monitors were assigned to BS courses. These teachers have diversified backgrounds, such as accounting, management or economics. Besides the software (a professional ERP), computers, printers, scanners, telephones, barcode readers, mail boxes that were customized for this project, and archive materials were organized into two classrooms as seen in Figure 1. 
P. Silva: Using Business Simulation Methodologies in Higher Education: Lessons

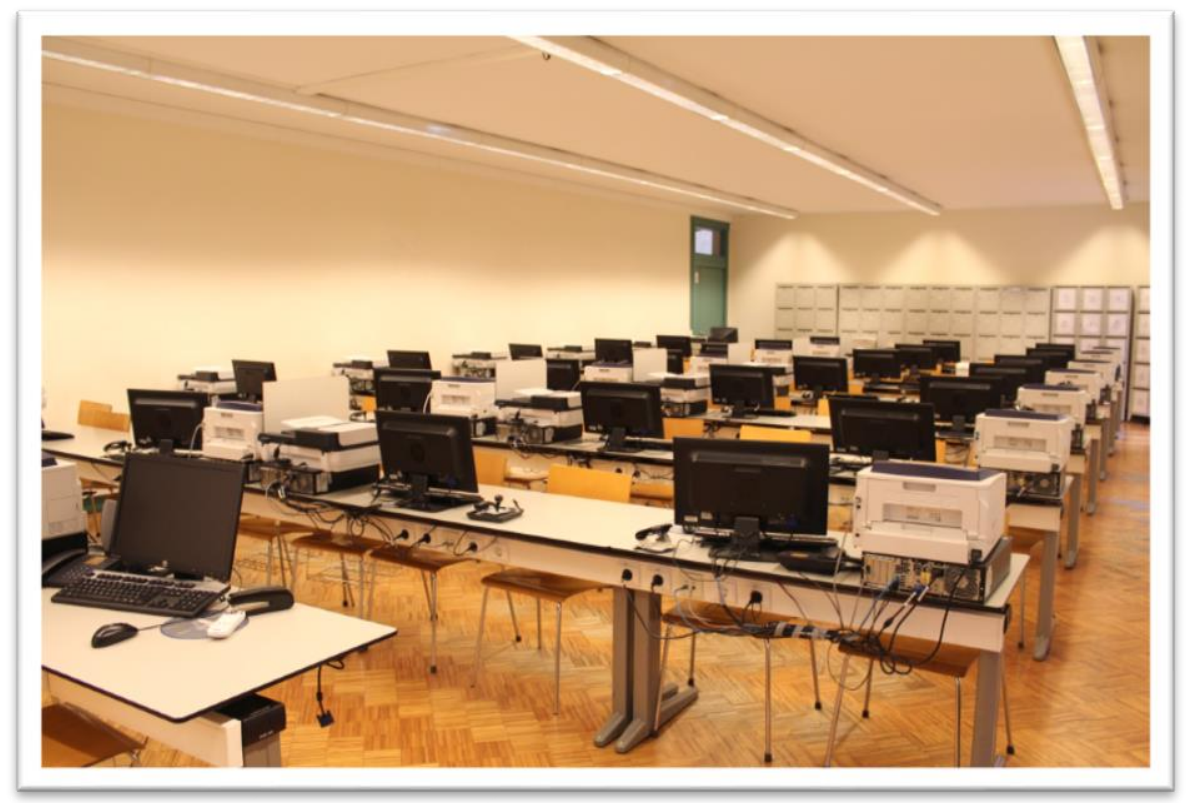

Figure 1: Business Simulation Classroom

\subsection{Classes}

During classes, teachers explain the activities that students need to develop according to a session guide, in which all activities were provided in advance of two sessions. Students also have the support from teachers when they have difficulties in performing the proposed activities. In each session, the teacher is assisted by one or two monitors. These professionals are graduated in accounting and management areas and are very well prepared in terms of software. The support of monitors is extended into other activities, such as administrative services and preparation of support documents for the classes. Students are divided into groups, each one representing a company. Each company has two computers, a printer, a scanner, a telephone, a barcode reader and three physical archives, among other office material (see Figure 2). For the control attendance, each student has a personal card that passes into the attendance control machine at the beginning and at the end of each class. 
$1^{\text {ST }}$ InTERnATIONAL SCIENTIFIC CONFERENCE $»$ TeACHING METHOdS FOR ECONOMICS AND BUSINESS SCIENCES«

P. Silva: Using Business Simulation Methodologies in Higher Education: Lessons Learned

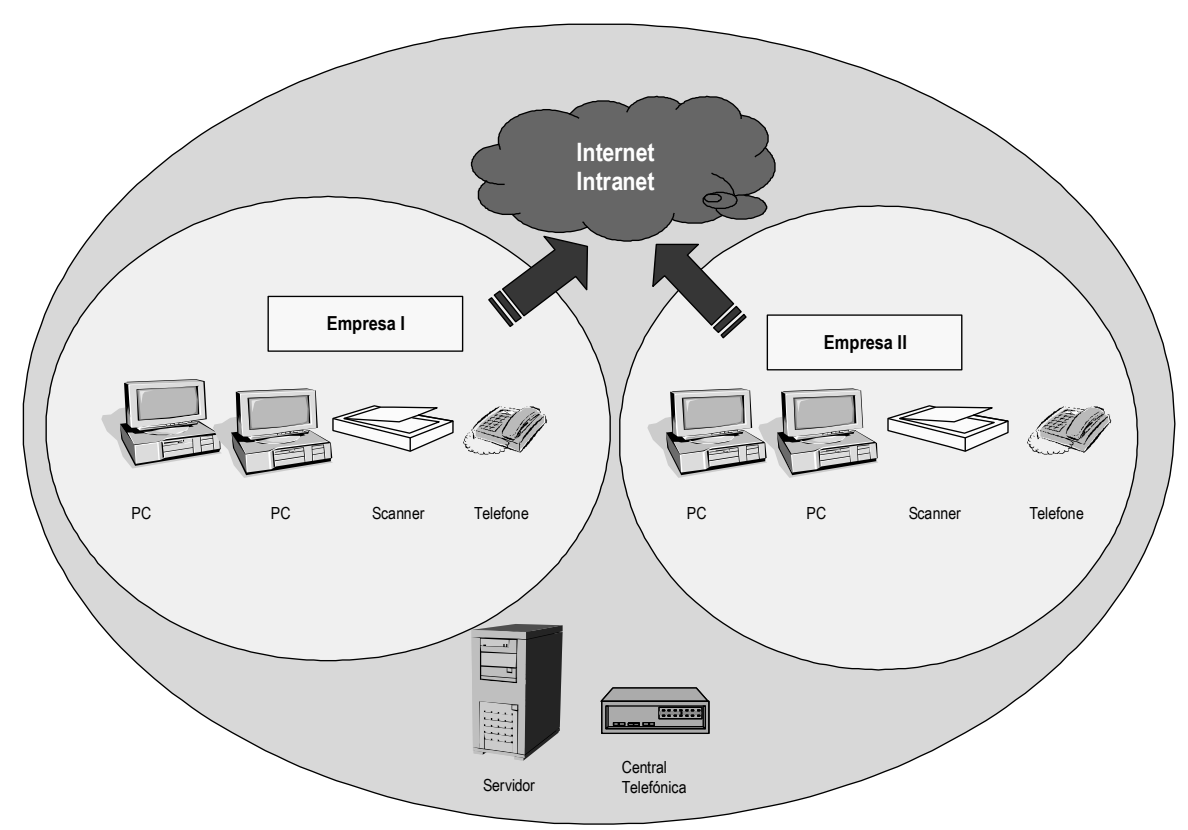

Figure 2: Example of companies' operation (Source: Business Simulation Guide I)

\subsection{The business environment}

The basis of BS courses is the business simulation model which consists of a market in which students' companies interact among themselves and with other external entities (see Figure 3). These external entities, such as social security, tax office, insurance company, bank, leasing company, factoring company, associations, just to mention a few, are managed by teachers and monitors. Students' companies compete and cooperate within the market and use collected information from real news to manage their own companies. Some activities, such as taxes and social security payments are aligned with a real calendar. Students need to perform these activities in a specific session of the month, which creates a certain professional pressure to be on time. Even the payroll management is performed in the last session of the month. Quality was, since the beginning, a preoccupation within the business environment. Students' companies were managed according to the ISO 9001:2000 standards. 
P. Silva: Using Business Simulation Methodologies in Higher Education: Lessons

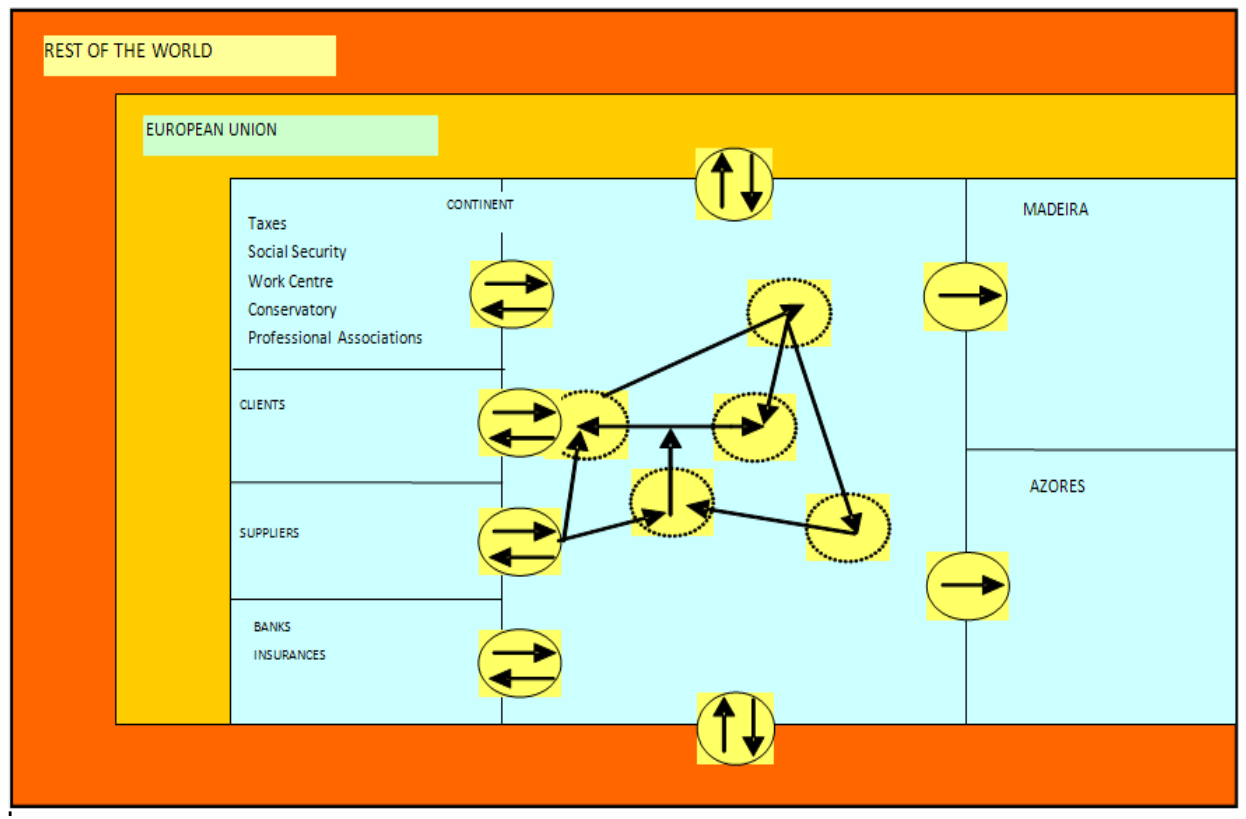

Figure 3: Business Simulation model (Source: Business Simulation Guide II)

\section{Evaluation}

The number of sessions for each semester is defined previously and must be accomplished strictly, because the activities and the links between them are planned. Students are assessed according to successful activities' performing. For the activities performance students have the session guide, a document that gives them the details of activities. This document can be printed, but also can be assessed digitally. There is a regulation, specifically created for the BS courses, the regulation of registry, attendance and evaluation (ISCAP, 2003). Besides other important considerations, this document provides the general rules for students' evaluation. The final grade of each student is essentially composed by two parts: group evaluation that represents $65 \%$ of the final grade and the individual evaluation that represents $35 \%$ of the final grade. As a result of the team work, group evaluation is obtained through two main parts, continuous evaluation and punctual evaluation. Continuous evaluation is mainly obtained during the classes, ant it is related with activities performed. Punctual evaluation is related with the audit of physical archives and with the final report. Despite the fact, there is a software that enables the management of all physical documents, it is compulsory for companies to have some paper documents saved, especially the ones related with the accounting system. So, physical archives are supposed to be well organized as it was in a real company. The final report is written in a paper document format (as a part of the group evaluation) and is also presented orally (as a part of the individual evaluation) at the end of the semester. This report encompasses a detailed description of the activities 
$1^{\text {ST }}$ INTERNATIONAL SCIENTIFIC CONFERENCE $\gg$ TEACHING METHODS FOR ECONOMICS AND BUSINESS SCIENCES «

P. Silva: Using Business Simulation Methodologies in Higher Education: Lessons Learned

performed, including strategic initiatives and a full financial analysis. The main financial statements, such as the balance sheet, the income statement and the cash flow statement are also included. The $35 \%$ of individual evaluation is divided into three parts: assiduity and punctuality, ethics and attitude, and oral presentation of the final report. Assiduity and punctuality means the student should attend all the classes and be responsible to be on time. This is how it should be in a real company. Ethics and attitude means the student should behave during the classes as they were in their job, work as a team, helping their colleagues, manage conflicts effectively, etc. The oral presentation of the final report is a test of the students in terms of their oral communication skills. As there is a time limit for the presentation, time management is also evaluated.

Writing and oral communication skills are very worked in class. Writing and oral communication skills are developed through different main activities. Writing skills are assessed through the intermediate report, a work group that develops a topic and the final report. Oral communication skills are assessed through the oral presentation of the work group and through the oral presentation of the final report.

\section{$5 \quad$ Lessons learned and conclusion}

Since February 2003, BS courses have been considered a very successful project at ISCAP-IPP, even knowing that the accounting and administration degree was changed to accommodate these courses. Students, teachers and employers were aligned in recognizing the merit of the project, which is in line with previous research studies (Bertuzi \& Silva, 2016; P. Silva, Bertuzi, \& Mesquita, 2016; P. L. Silva, Santos, \& Vieira, 2014; P. Silva, Mesquita, \& Bertuzi, 2015, 2016). The project had motivated external positive reactions by several entities. Among them we have the Portuguese Ministry of Science and Higher Education, other universities, intermediate schools, technological companies, associations and educational centres. Our Minister of Science and Higher Education visited ISCAP-IPP, the president of the Polytechnic of Porto had publicly revealed pride for BS project. This educational project was also chosen by other higher education institutions and it is still in place as well. During all these years, feedback from the students has been very positive. Teachers also are optimistic about the effective impact of BS courses in improving students' background. For several times, employers give very good feedback about the preparation of students. One of their most valued aspects of the training was the work under pressure with strict deadlines, as it happens very frequently in real life. The impact is very valuable for students that have the opportunity not only to learn how to work, but specially learn by doing. Problem-solving skills are improved this way. This is the main philosophy used in BS courses. As BS courses are provided also to students with some work experience we could expect less impact on those students. The feedback we received from them is that BS courses are very important for them, not only to experience another approach of the labour market, but especially because they learn how to do things correctly. Another important point transmitted by students is that they improve oral and written communication skills. The activities they need to do during classes and as homework related with written works are very demanding, leading to a consequent improvement. The teamwork was also strongly 
P. Silva: Using Business Simulation Methodologies in Higher Education: Lessons

emphasized when it comes to skills improvement. Students value the fact they do exactly what they will do in the real job. This is a way of being much more secure about their own capacities when they prepare themselves for a first job interview or for their first work experience. Besides a continuous improvement policy that is in place and results from a quality philosophy, there are still points that need to be improved. Creativity and marketing are still the areas that could be much more developed in BS courses, but because of lack of time and a more financial focus, associated with the accounting and administration programme of studies, they remain as a non-priority issue. Nevertheless, we realized that methodologies used in BS courses are in line with a more demanding higher education and business world.

\section{References}

Adler, R. W., \& Milne, M. J. (1997). Improving the quality of accounting students' learning through action-oriented learning tasks. Accounting Education, 6(3), 191-215. https://doi.org/10.1080/096392897331442

Bertuzi, R., \& Silva, P. (2016). The importance of the competences learned in the first job. In ICERI2016 Conference (pp. 1284-1291). Seville, Spain: IATED.

BS. (2003a). Business simulation guide I. Business Simulation Team.

BS. (2003b). Business simulation guide II. Business Simulation Team.

IAESB. (2014). Handbook of international education pronouncements 2014 edition. International Accounting Education Standards Board. New York: USA.

IFAC. (2010). Handbook of international education pronouncements - August 2010. International Federation of Accountants. New York: USA.

ISCAP, C. P. (2003). Regulamento de inscrição, funcionamento e avaliação das unidades curriculares projeto de simulação empresarial i e projeto de simulação empresarial II.

Lin, Z. J., Xiong, X., \& Liu, M. (2005). Knowledge base and skill development in accounting education: Evidence from China. Journal of Accounting Education, 23, 149-169.

Silva, P., Bertuzi, R., \& Mesquita, A. (2016). Business simulation before and after Entre4Future project: Lessons learned. In EDULEARN16 Conference (pp. 8889-8897). Barcelona, Spain.

Silva, P. L., Santos, J. F., \& Vieira, I. (2014). Teaching accounting and management through business simulation: A case study. In E. Ariwa (Ed.), Green technology applications for enterprise and academic innovation (pp. 33-47). Hershey, PA: Information Science Reference. Retrieved form https://doi.org/10.4018/978-1-4666-5166-1.ch003

Silva, P., Mesquita, A., \& Bertuzi, R. (2015). Simulation for entrepreneurship - ENTRE4FUTURE: An ongoing European project. In Technological Ecosystems for Enhancing Multiculturality - TEEM'15. Porto, Portugal: Polytechnic of Porto - School of Engineering (ISEP).

Silva, P., Mesquita, A., \& Bertuzi, R. (2016). The Entre4Future project: Educate entrepreneurs through simulation methodologies. In INTED2016 Conference (pp. 6659-6668). Valencia, Spain. 
$128 \mid 1^{\text {ST }}$ InTERnational SCIENTIFic CONFERENCE »TEACHING METHOdS For ECONOMiCS AND BUSINESS SCIENCES« 


\title{
Nonformal Activities for the Improvement of the Development of Vocational Competences - the Polish Example
}

\author{
MACIEJ SZAFrAŃSKi, MAREK GOLIŃSKI, EWA WIECEK-JANKA, MAGDALENA GRACZYK- \\ KUCHARSKA \& MAGORZATA SPYCHAŁA
}

\begin{abstract}
The review of methods and tools of formation of professional competences in Poland is shown in this article. The characteristics of the development of transversal and professional competences are presented as well as the forms of teaching them in formal, nonformal and informal way. The elaborated and developed national and regional policy helps to accelerate the improvement of vocational education in Poland. Presented project Time for Professionals BIS - Professional Wielkopolska Region helps in implementing many social innovations in vocational education. Contributions, idea and also the way of the implementation of that project are shown in this paper. The model of transforming of implemented and multi-annual activities in sustainable structure of the cooperation in the form of Economic-Educational Network in Wielkopolska Region is presented, which should help in the future multiplication of positive effects of the development of professional competences improvement in Poland.
\end{abstract}

Keywords: • vocational learning $\bullet$ projects $\bullet$ acceleration $\bullet$ knowledge management $\bullet$ competences $\bullet$

Correspondence AdDresses: Maciej Szafrański, Ph.D., Assistant Professor, Poznań University of Technology, ul. Strzelecka 1160-965 Poznań, Poland, e-mail: maciej.szafranski@put.poznan.pl. Marek Goliński, Ph.D. Assistant Professor, Poznań University of Technology, ul. Strzelecka 1160965 Poznań, Poland, e-mail: marek.golinski@put.poznanska.pl. Ewa Wiecek-Janka, Ph.D., Assistant Professor, Poznań University of Technology, ul. Strzelecka 1160-965 Poznań, Poland, email: ewa.wiecek-janka@ put.poznan.pl. Magdalena Graczyk-Kucharska, Ph.D., Assistant, Poznań University of Technology, ul. Strzelecka 1160-965 Poznań, Poland, e-mail: magdalena.graczykkucharska@put.poznan.pl. Magorzata Spychała, Assistant Professor, Poznań University of Technology, ul. Strzelecka 1160-965 Poznań, Poland, e-mail: malgorzata.spychala@ put.poznan.pl.

https://doi.org/10.18690/978-961-286-091-2.12

ISBN 978-961-286-091-2

(C) 2017 University of Maribor Press

Available at: http://press.um.si. 
$1^{\text {ST }}$ InTERnational SCIENTIFiC CONFERENCE $\gg$ TEACHING METHOdS FOR ECONOMICS AND BUSINESS SCIENCES«

M. Szafrański, M. Goliński, E. Wiecek-Janka, M. Graczyk-Kucharska \& M. Spychała:

Nonformal Activities for the Improvement of the Development of Vocational

Competences - the Polish Example

\section{Development of vocational competences in Poland}

\subsection{The notion and classification of competences}

Daily functioning of a human being provides plenty of situations which provoke the acquisition of competences. They are as important from the point of view of a business in order to create its values, culture, ethics, norms and climate (Belak \& Hauptman, 2011) both in private as well as public enterprises (Duh \& Štrukelj, 2017). However, we are not always able to use them in practice. It is the core of our deliberations on the development of competences to come up with an approach which combines both processes: the acquisition and the use of competences in the context of the demand for them in the employment market.

In common language, press publications, radio and TV statements as well as in documents which describe the Polish education system, terms such as competences, skills and qualifications are used interchangeably. However, this is not correct. Following the requirements for a detailed definition, we assume that competences require the acquisition of a certain scope of knowledge and give us the feeling that "we know what", and they let us use the knowledge in practice, i.e. "we know how", as well as being characterized by positive attitude, i.e. "we want to use our knowledge". There are also authors (Kossowska \& Sołtysińska, 2002) who add the features of one's personality as another element of competences to the list.

The body of literature on the subject is full of various classifications of competences (Lelińska, 2016; Rostowski, 2002; Woodruffe, 2003; Filipowicz, 2000). The classification which takes functional separation into account is one of the more popular ones. In this case Filipowicz (2000) lists: (1) personal competences connected with an individual approach to completion of tasks and striving at results, flexibility of thinking, analytical thinking, etc.; (2) social competences which are connected with the quality of completed tasks, especially in contact with other people, affect the effectiveness of cooperation and include: self-presentation, building relations with other people, communicativeness, openness to others, etc.; (3) managerial competences connected with staff management on which the organizational effectiveness of the organization depends. Key managerial competences include task delegation, management, motivating, strategic thinking, etc.; (4) specialist competences connected with completion of specific professional requirements.

As it can be suspected, competences are not permanent structures - they change not only under the influence of educational processes but also (or perhaps first and foremost) under the influence of experience which verifies knowledge in business practice situations (Duh et al., 2015). The development of a competence can be treated as a continuous process which is characterized by the fact that the longer we work on it, the higher the level we achieve. 
M. Szafrański, M. Goliński, E. Wiecek-Janka, M. Graczyk-Kucharska \& M. Spychała: Nonformal Activities for the Improvement of the Development of Vocational Competences - the Polish Example

Setting the level of competences and their growth is an ambiguous process which cannot be captured by objective measurements. Despite the difficulties, theoreticians (Filipowicz, 2000; Spychała, 2013; Branowska et al., 2012) consider observation of competence-characteristic behaviors as the best method for their evaluation. The fivelevel scale is the most often used instrument for the evaluation of competences: A(1) means the lack of a given competence (shows no behaviors proving that it has been acquired and is used in undertaken actions); $\mathrm{B}(2)$ means basic acquisition of a competence which means that it is used irregularly; $\mathrm{C}(3)$ says that a competence has been acquired to a good degree which enables its independent and practical use when completing professional tasks; $\mathrm{D}(4)$ determines competences which have been acquired to a very good degree and that contributes to completion of tasks from a given area; $\mathrm{E}(5)$ means that the competences in question are used at an excellent level. Moreover, the highest level of use of competences provides information about capacities of creative use and development of knowledge, skills and attitudes proper for a given scope of activities.

The development of competences needs to be considered an intentional process which can be competed via various paths, with the three basic forms of education being: the formal, non-formal and informal one.

\subsection{Forms of learning vocational competences}

Formal learning means institutional and formalized learning completed according to programs which enable acquisition of qualifications recognized in a given legal system. Informal learning means intended learning (self-learning) and unintended learning which is unknowingly present in daily life situations as well as when the person acquires experience during work outside of formal and non-formal trainings which are organized at the workplace. This form of learning is usually unorganized and inconsistent and covers any way in which knowledge and experience is acquired. Nonformal learning means institutional and formalized learning completed outside of programs which enable acquisition of qualifications recognized in a given legal system. It covers planned, intended and consistent activities, e.g. in the form of courses and trainings (Straka, 2002, pp. 152-156; Maslowski et al. 2009, pp. 11-19).

A diploma proving graduation from a school is not enough to provide the full picture of an employee's competences as it is only the effect of formal learning. Apart from acquiring knowledge and skills and shaping attitudes the formal way, the employee improves their competences when taking part in practical trainings and scientific circles or organizing holiday trips. Table 1 presents the examples of the development and improvement of student competences via the formal, nonformal and informal route. 
$1^{\text {ST }}$ INTERNATIONAL SCIENTIFIC CONFERENCE »TEACHING Methods FOR ECONOMicS AND BUSINESS SCIENCES«

M. Szafrański, M. Goliński, E. Wiecek-Janka, M. Graczyk-Kucharska \& M. Spychała:

Nonformal Activities for the Improvement of the Development of Vocational

Competences - the Polish Example

Table 1: Examples of student learning

\begin{tabular}{|c|c|}
\hline $\begin{array}{l}\text { Types of } \\
\text { learning }\end{array}$ & Examples \\
\hline Formal learning & $\begin{array}{l}\text { - upper secondary school (secondary school of technical } \\
\text { education, secondary school of general education) } \\
\text { - studies in the selected field of study, } \\
\text { - postgraduate studies in a given scope. }\end{array}$ \\
\hline Informal learning & $\begin{array}{l}\text { - } \text { self-development - reading literature connected with the } \\
\text { profession, interests, } \\
\text { - } \text { information and guidelines acquired from other people, e.g. } \\
\text { family and friends, } \\
\text { - learning through discussion, } \\
\text { - experience acquired in life situations, e.g. organizing a holiday } \\
\text { trip, organizing a concert, } \\
\text { - } \text { consultations with various specialists in a given area, } \\
\text { - imitating people who succeeded in a given area. }\end{array}$ \\
\hline $\begin{array}{l}\text { Nonformal } \\
\text { learning }\end{array}$ & $\begin{array}{l}\text { - professional work, } \\
\text { - running one's own business, } \\
\text { - learning during practical trainings, internships - experience } \\
\text { acquired in an organization, learning from experienced } \\
\text { superiors, imitating the employees who perform the tasks } \\
\text { correctly and in line with the organizational standards, } \\
\text { - taking part in trainings in a given area, } \\
\text { - participation in workshops, } \\
\text { - } \text { participation in scientific circles. }\end{array}$ \\
\hline
\end{tabular}

(Source: Spychała \& Matejun, Badanie ocen wybranych kompetencji menedżerskich studentów WOiZ Politechniki Łódzkiej, (Examining the evaluation of selected managerial competences of University of Łódź WOiZ students"), "Marketing i Rynek", 5/2015, pp. 1274-1293.)

According to the table, the student expands their competences by applying various methods and techniques. However, not every area of development can be documented, e.g. experience won in various life situations or recommendations acquired from other people. Despite that, the future employee will be able to use given tools or apply certain methods. Focusing on actual market requirements, it is possible to prepare students of upper secondary schools to perform tasks in workplaces in the future (Spychała, 2015). 
M. Szafrański, M. Goliński, E. Wiecek-Janka, M. Graczyk-Kucharska \& M. Spychała: Nonformal Activities for the Improvement of the Development of Vocational Competences - the Polish Example The EU program for the support of development of vocational competences

Due to the need to accelerate the development of vocational education, and in order to adjust it to the requirements of knowledge-based economy, in particular to the needs of businesses, Poland develops and improves national and regional policies in that respect (Matusiak, 2015; Zarząa Województwa Wielkopolskiego, 2012). Since 2004, EU funds have provided important support for those policies having been paid out to Poland as well as other European Union member states. The programs are used to finance various projects, both investment-related as well as social ones. The latter are financed from the European Social Fund. The framework program for the years 2014-2020 is being completed at the moment. Some of the funds under it have been allocated to the development of vocational education. The funds are consumed both at the national as well as the regional level.

The principles for the use of EU funds for the development of vocational education stem from the Guidelines for completion of projects with the use of the European Social Fund in the area of education for the years 2014-2020 (Minister of Development, 2016, pp. 4564 ), which are consistent with the aforementioned national policies and programs. Importantly, it was agreed that activities financed from EU funds should be additional in relation to formal vocational education program. It means that the European Union does not support activities which are financed by national funds in the vocational education system. The guidelines include general principles and directions for spending the money; however, they do require further detailing in the form of specific projects which will enable specific activities. Wielkopolska province has adopted the Wielkopolska Regional Operational Program 2014+ (the Wielkopolska Province Management, 2014). Its completion has been tasked to the Wielkopolska Province Self-Government. The Program comprises eight priority axes for the activities (Wielkopolskie Province Marshal's Office, 2015, pp. 221-275), with one of them, the eighth one, concerning education. As part of that axis, three categories of activities were distinguished while one of them (8.3) titled 'Strengthening and adjusting vocational education and training for the purposes of the employment market' concerns the acceleration of vocational education in Wielkopolska. Moreover, the region's authorities want to develop vocational education so that it supportes the development of businesses. Universities should be perceived as an important component in land development and human capital development (Petrikova et al., 2016). It must be pointed out that the needs and expectations of businesses constitute the genesis of activities in the program. Naturally, it must be expected that activities undertaken in the program should differ from the ones provided for in the formal learning system. It stems from the well known fact that vocational education in Poland, which is based on programs developed in the Ministry of National Education, is unable to keep up with the changing needs of businesses (Kocór \& Strzebońska, 2014 p. 69, pp. 72-73; Pfeiffer et al., 2012 p. 25, 99; Zaręba et al., 2013). This is not an accusation of the Ministry; it is a statement of the fact which will be difficult to eliminate basing only on the formal learning core curriculum whose naturalness stems from its very name (the word 'core'). Activity category 8.3 is divided into 3 sub-categories. 
$1^{\text {ST }}$ INTERNATIONAL SCIENTIFIC CONFERENCE »TEACHING Methods FOR ECONOMiCS AND BUSINESS SCIENCES«

M. Szafrański, M. Goliński, E. Wiecek-Janka, M. Graczyk-Kucharska \& M. Spychała:

Nonformal Activities for the Improvement of the Development of Vocational

Competences - the Polish Example

They are:

- vocational education of youth - contest mode (8.3.1),

- vocational education of adults - contest mode (8.3.2), and

- Time of Professional BIS - professional Wielkopolska - non-contest mode (8.3.3).

In the case of the first two sub-categories, contests are organized for various entities which submit project proposals while a single big systemic project is completed in the case of the third sub-category with the Wielkopolska Province Self-Government being its leading partner and the Poznan University of Technology, the biggest university in NorthWestern Poland, being its other partner. The program is also partnered by several dozen secondary schools of technical education and several hundred businesses from Wielkopolska, a region of about 3.6 million residents. The system of activities planned and completed in the project is an example of a big social innovation. Before we focus on the activities undertaken in the region, it is necessary to present the genesis of the project which started in late 2015 and will continue until 2022. Its creators wish the developed results to continue in the following years as well.

\section{The Time of Professionals Initiative}

The launch of the Time of Professional BIS - professional Wielkopolska (Czas Zawodowców BIS - zawodowa Wielkopolska (CZ BIS-ZW)) project is a result of longterm activities undertaken by the Poznan University of Technology and its partners under the Technical Knowledge Accelerator (Akcelerator Wiedzy Technicznej ${ }^{\circledR}(A W T \circledR)$ ) initiative. The development of the initiative since 2006 has been presented in Figure 1. The project follows the below mentioned projects which were completed before: The Wielkopolska System for Monitoring and Forecasting (Wielkopolski System Monitorowania $i$ Prognozowania - WSMiP) (Szafrański, 2011) and Time of Professionals -Wielkopolska vocational education (Czas Zawodowców - wielkopolskie ksztatcenie zawodowe - CZ-WKZ) (Szafrański, 2015c). As it can be seen from Figure 1, they are composed of original concepts which were developed when the Acceleration Program for Technical, Mathematical and Natural Science Knowledge (Program akceleracji wiedzy technicznej i matematyczno-przyrodniczej) was first developed in 2008. Time of Professionals, which has been completed since 2012, should be treated as one of the initiatives launched by the Wielkopolska Province Self-Government and the Poznan University of Technology. It is the ambition of the parties to transform it into a permanent cooperation structure in the form of the Wielkopolska Educational-andEconomic Network (Wielkopolska Sieć Edukacyjno-Gospodarcza - WSEG) (Szafrański 2015a; Szafrański et al. 2016). It is the strength of the developed innovative organizational solutions in the social sphere that they are universal in nature and have the potential to be implemented in other Polish and European regions. A number of results generated under Time of Professionals requires a scientific approach from the areas of 
M. Szafrański, M. Goliński, E. Wiecek-Janka, M. Graczyk-Kucharska \& M. Spychała: Nonformal Activities for the Improvement of the Development of Vocational Competences - the Polish Example

knowledge management and quality management as it has been confirmed in many scientific publications, e.g. (Szafrański, 2011; Szafrański 2015c).

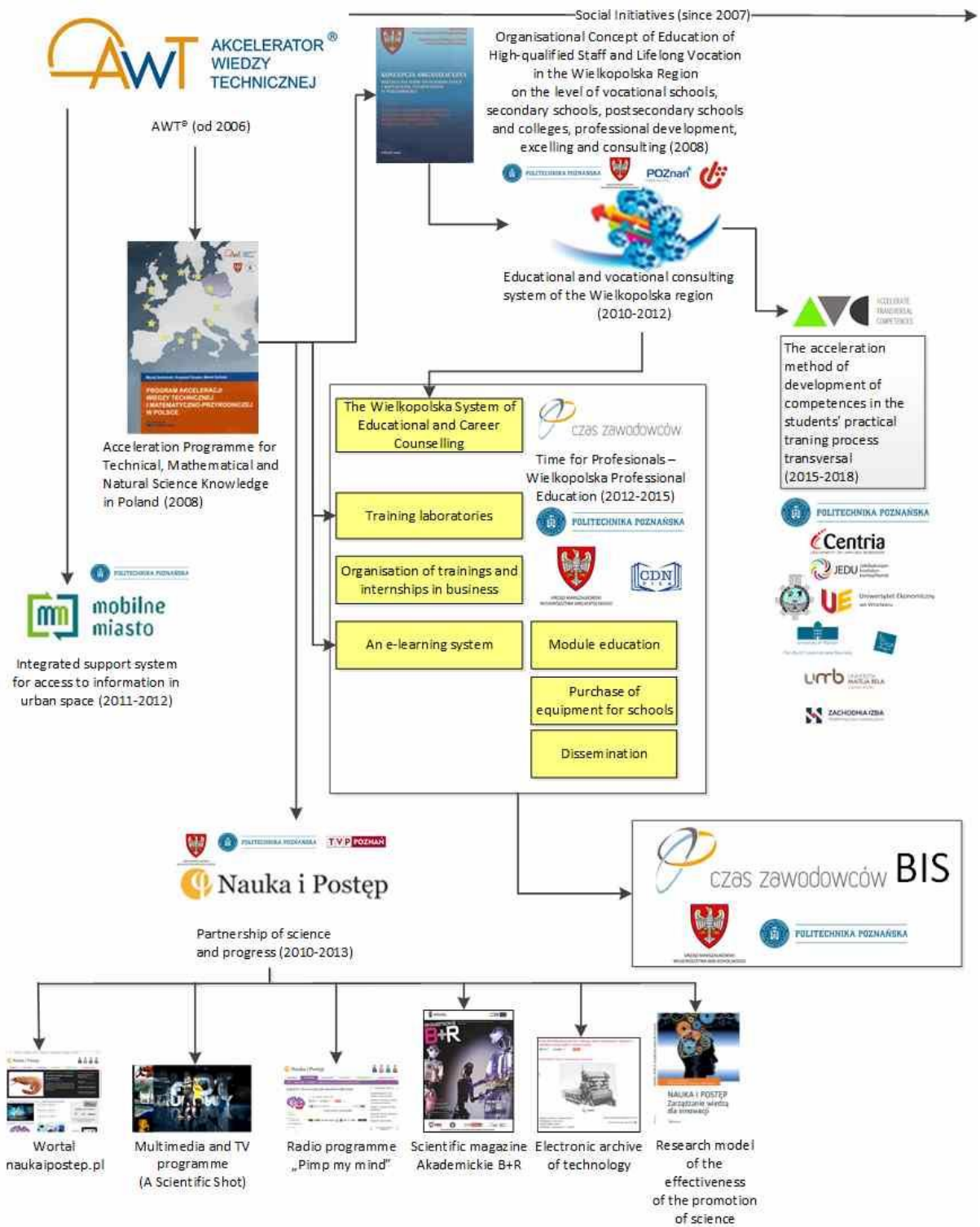

Figure 1: The Time of Professionals Initiative vs. the Technical Knowledge Accelerator initiatives 
$1^{\text {ST }}$ InTERNATIONAL SCIENTIFIC CONFERENCE $\gg$ TEACHING Methods FOR ECONOMiCS AND BUSINESS SCIENCES«

M. Szafrański, M. Goliński, E. Wiecek-Janka, M. Graczyk-Kucharska \& M. Spychała:

Nonformal Activities for the Improvement of the Development of Vocational

Competences - the Polish Example

Activities under the Time of Professionals Initiative for the development of vocational competences in Wielkopolska

Time of Professional BIS - professional Wielkopolska needs to be perceived in two aspects: the scientific and the utilitarian one.

In the scientific dimension, the project responds to the problem of shortage of employees with qualification and professional competence levels expected by businesses. Scientific works in the project are located in the sciences on management, in particular quality management and knowledge management. The activities were limited to the Wielkopolska province area due to the province authorities' need to solve the aforementioned problem. The activities undertaken in the project stem from scientific observations - interpretations of phenomena occurring on the market, a detailed analysis of separate cases of the identification of businesses' needs as well as statistical questions and answers which make it possible to interpret the phenomena on the scale of the region. The effects of the studies are analyzed critically by reference to scientific publications devoted to management.

The project focuses on graduates from vocational upper secondary schools for three reasons. Firstly, the problem of the lack of work among young people is vastly communicated - it is not only a problem of the region or the country, it is a problem of the whole Europe. Secondly, employers employ staff with vocational upper secondary education on over 50\% positions (Central Statistical Office). Thirdly, employers are not pleased with the preparation level of vocational school graduates for work (Szafrański, 2015 b, pp. 29-35), as it was proved on the basis of interviews conducted with representatives of employers under ended project CZ - WKZ.

The basic research goals of the project whose achievement is meant to permanently reduce the aforementioned problem identified in businesses are:

- coming up with a method for diagnosing the expectations of employers with respect to vocational competences of upper secondary school graduates who look for work;

- diagnosing the demand for competences with the developed method, providing feedback in the form of information about the availability of analyzed competences among graduates from upper secondary vocational schools;

- facilitating the process of communication between employers and students and graduates of vocational schools which was initiated and implemented under WSMiP and CZ-WKZ projects,

- diagnosing competence profiles of students of final years of upper secondary schools as part of the communication process with employers interested in implementing or developing quality management in businesses through knowledge management; 
M. Szafrański, M. Goliński, E. Wiecek-Janka, M. Graczyk-Kucharska \& M. Spychała: Nonformal Activities for the Improvement of the Development of Vocational Competences - the Polish Example

- coming up with a method of including businesses in the process of career counselling for students of upper secondary vocational schools and the process of educating them - a method extending the array of preventive activities in businesses; and

- coming up with more details for the model of the Wielkopolska Educational and Economic Network whose concept was developed under prior activities (Szafrański, 2015a, Szafrański et al. 2016) and implementation of that model.

It is the core of the activities undertaken in the project to implement and ensure the application of methods referred to in the research goals. The use of the methods serves the purpose of achieving the ultimate goal, i.e. the acceleration of the adjustment of the level of competences of graduates from upper secondary vocational schools to the needs diagnosed in businesses.

The achievement of the research goals is possible as a result of several key operational activities which ensure measurable practical benefits for the region as exampled by Minister of Regional Development's Best Investment into the Human Being 2014 award granted in 2015 to CZ-WKZ under the $8^{\text {th }}$ countywide contest Good Practice European Social Fund 2014 and the decision of the Wielkopolska Province Self-Government on continuing the project in the form of CZ BIS-ZW. Activities in the project constitute 'casing' of the formal vocational education process as depicted in Figure 2 which also lists the key activities in the project. 
$1^{\text {ST }}$ INTERNATIONAL SCIENTIFIC CONFERENCE »TEACHING METHOdS FOR ECONOMICS AND BUSINESS SCIENCES«

M. Szafrański, M. Goliński, E. Wiecek-Janka, M. Graczyk-Kucharska \& M. Spychała:

Nonformal Activities for the Improvement of the Development of Vocational

Competences - the Polish Example

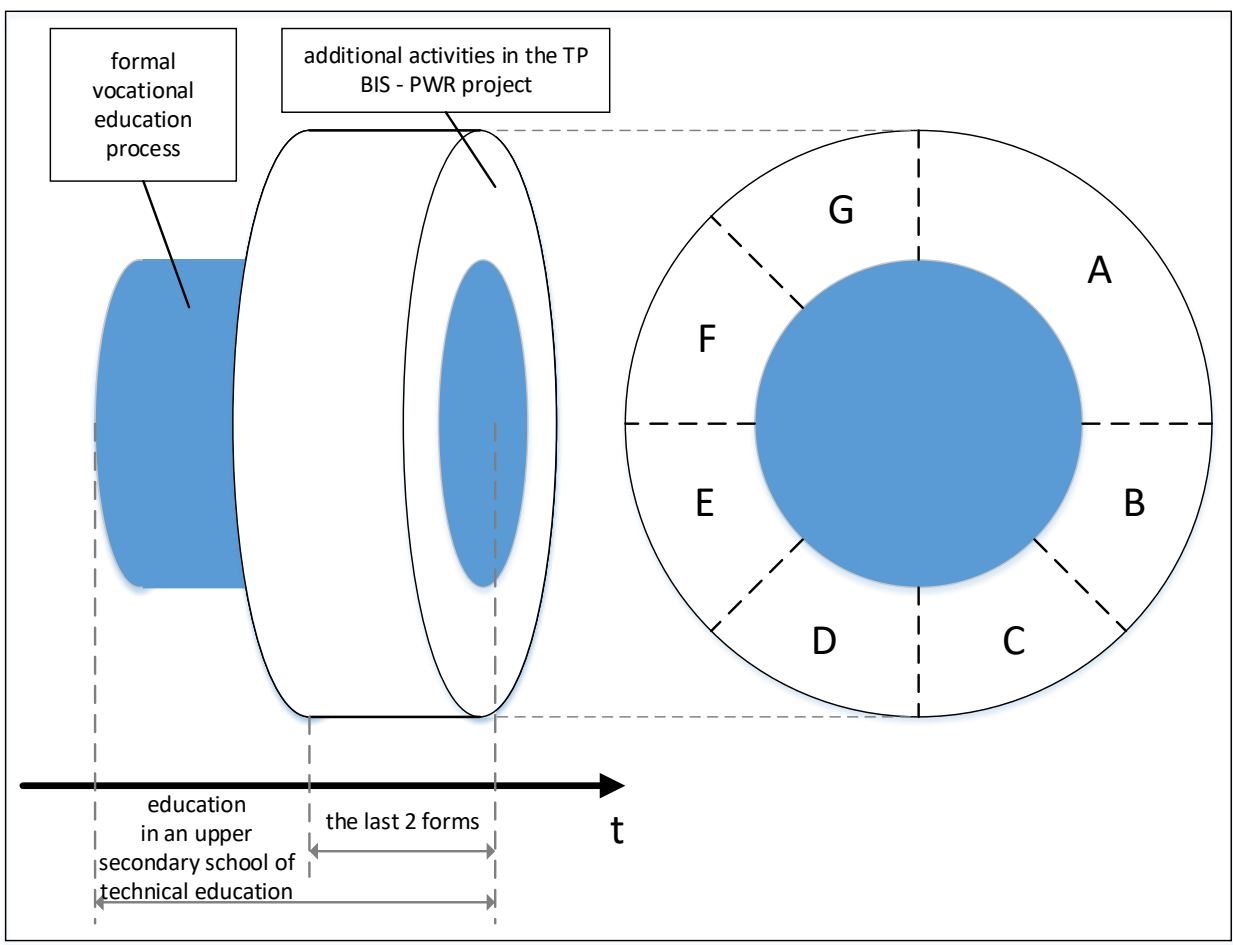

Figure 2: Activities in the Time of Professional BIS - professional Wielkopolska project: A - student internships in businesses, B - specialist classes in laboratories, C IT support for teachers and students via the Professionals System and WSEG, D development of didactic materials for students and teachers, $\mathrm{E}$ - providing schools with extra equipment, F - support for teachers of vocational subjects, $\mathrm{G}$ - patronage of the Poznań University of Technology.

The additional nature of CZ BIS-ZW activities mentioned in Chapter 2 in the utilitarian aspect is meant to serve the acceleration of:

- the preparation of young people for work in the conditions of growing volatility of markets and the economy;

- giving students of senior years in technical schools basic knowledge in own competence management; and

- creating conditions which facilitate shortening employees' adaptation to jobs in businesses and identifying and reducing the risk of hiring candidates with a wrong scope of competences.

Table 1 presents brief characteristics of separate activities. 
M. Szafrański, M. Goliński, E. Wiecek-Janka, M. Graczyk-Kucharska \& M. Spychała: Nonformal Activities for the Improvement of the Development of Vocational Competences - the Polish Example

Table 1. Characteristics of the key activities in the Time of Professionals BIS professional Wielkopolska project

\begin{tabular}{|c|c|c|}
\hline Symbol & Activity & Characteristics \\
\hline A & $\begin{array}{l}\text { student internships in } \\
\text { businesses }\end{array}$ & $\begin{array}{l}\text { assistance in shaping relations between } \\
\text { businesses and schools and students; aid in the } \\
\text { preparation of internship programs, student } \\
\text { support in career counselling; an offer of } 8,000 \\
\text { internships in the cooperating businesses and } \\
\text { internship scholarships; }\end{array}$ \\
\hline B & $\begin{array}{l}\text { specialist classes in } \\
\text { laboratories }\end{array}$ & $\begin{array}{l}40 \text { hours in specialist laboratories for every } \\
\text { student in one of } 3 \text { locations (Poznan, Piła, } \\
\text { Kalisz) in one of } 12 \text { technical professions: } \\
\text { information technology technician, ITC } \\
\text { technician, mechanic, mechatronics technician, } \\
\text { electrician, electronic technician, economist, } \\
\text { merchant, logistician, freight forwarder, } \\
\text { advertisement organization technician, graphic } \\
\text { digital processes technician; an offer of } \\
\text { transportation as well as accommodation and } \\
\text { catering for students and their guardians; } \\
\text { improvement with respect to selected } \\
\text { competences from the vocational education core } \\
\text { curriculum; the principles of preparation of the } \\
\text { specialist classes were presented on figure } 3 \text {; the } \\
\text { classes are a modified continuation of } \\
\text { laboratory practice trainings held in 2013-2015; } \\
\text { an offer for at least } 10,000 \text { students until 2022; } \\
\text { more detailed information about the meaning of } \\
\text { the laboratories is available in Szafrański } \\
\text { (2014). }\end{array}$ \\
\hline $\mathrm{C}$ & $\begin{array}{l}\text { IT support for teachers } \\
\text { and students via the } \\
\text { Professionals System } \\
\text { (Szafrański, 2011) and } \\
\text { WSEG (Szafrański, } \\
\text { 2015a, Szafrański et al. } \\
\text { 2016) }\end{array}$ & $\begin{array}{l}\text { measurement of changes in the students' skills } \\
\text { with personal predispositions diagnosis tools; } \\
\text { support for communication between senior } \\
\text { years students of vocational schools and } \\
\text { employers; preparation of reports and in-depth } \\
\text { statistical analyses on the employment market; } \\
\text { development and popularization of the process } \\
\text { of measuring competences among vocational } \\
\text { education students; preparation of referential } \\
\text { models of jobs offered by employers and } \\
\text { improvement of the competence code } \\
\text { describing employers' needs; development of }\end{array}$ \\
\hline
\end{tabular}


$1^{\text {ST }}$ INTERNATIONAL SCIENTIFIC CONFERENCE $\gg$ TEACHING METHOdS FOR ECONOMICS AND BUSINESS SCIENCES«

M. Szafrański, M. Goliński, E. Wiecek-Janka, M. Graczyk-Kucharska \& M. Spychała:

Nonformal Activities for the Improvement of the Development of Vocational

Competences - the Polish Example

\begin{tabular}{|c|c|c|}
\hline & & $\begin{array}{l}\text { the educational and economic network with the } \\
\text { participation of schools, employers, local } \\
\text { governments and the Poznan University of } \\
\text { Technology, including expansion and } \\
\text { strengthening of relations between schools and } \\
\text { employers; activation of employers and their } \\
\text { inclusion in the processes of counselling } \\
\text { students with respect to directions of their } \\
\text { professional development; initiating and } \\
\text { keeping permanent relations with at least } 110 \\
\text { big employers from the region and at least } 5 \\
\text { entrepreneur organizations. The current model } \\
\text { results of the analyses carried out on the basis of } \\
\text { data from the system and thus the examples of } \\
\text { the capacities of the system were presented by } \\
\text { M. Goliński and M. Szafrański (Szafrański \& } \\
\text { Goliński, 2015a; Szafrański \& Goliński, } \\
\text { 2015b). }\end{array}$ \\
\hline D & $\begin{array}{l}\text { development of } \\
\text { didactic materials for } \\
\text { students and teachers }\end{array}$ & $\begin{array}{l}\text { provision of online didactic materials to } \\
\text { teachers of schools participating in the project } \\
\text { on an e-learning platform: } 32 \text { interactive } \\
\text { vocational courses in } 12 \text { professions covered by } \\
\text { the laboratories, } 50 \text { templates for independent } \\
\text { creation of online courses in various } \\
\text { methodological schemes, vocational test and } \\
\text { practical task bases for } 12 \text { professions; } \\
\text { providing the teachers with the possibility of } \\
\text { using multimedia materials, texts, pictures for } \\
\text { independent creation and supplementation of } \\
\text { the didactic materials for the students; } \\
\text { additionally, an offer of specialist external } \\
\text { courses; a career counselling repository; support } \\
\text { for teachers by sharing online instructions with } \\
\text { them, technical services for the platform, } \\
\text { organization of information panels in schools; } \\
\text { the materials will be prepared on the basis of } \\
\text { modern communication technologies with the } \\
\text { use of simulators, multimedia, animations; } \\
\text { technical preparation of the materials necessary } \\
\text { to teach classes in the laboratories: online tests } \\
\text { and materials for the support of additional } \\
\text { classes for students; the technical-and- } \\
\text { methodological concept of the platform was }\end{array}$ \\
\hline
\end{tabular}


M. Szafrański, M. Goliński, E. Wiecek-Janka, M. Graczyk-Kucharska \& M. Spychała: Nonformal Activities for the Improvement of the Development of Vocational Competences - the Polish Example

\begin{tabular}{|c|c|c|}
\hline & & $\begin{array}{l}\text { described by Szafrański, Goliński and Grupka } \\
\text { (Szafrański et al., 2014). }\end{array}$ \\
\hline $\mathrm{E}$ & $\begin{array}{l}\text { providing schools with } \\
\text { extra equipment }\end{array}$ & $\begin{array}{l}\text { providing extra equipment to } 46 \text { schools which } \\
\text { offer vocational education and providing } \\
\text { equipment and didactic aids for the vocational } \\
\text { learning room to } 4 \text { Wielkopolska local } \\
\text { governmental vocational and lifelong education } \\
\text { centres; diagnosis of the schools' needs; }\end{array}$ \\
\hline $\mathrm{F}$ & $\begin{array}{l}\text { support for teachers of } \\
\text { vocational subjects }\end{array}$ & $\begin{array}{l}\text { a proposal of courses enabling the acquisition of } \\
\text { professional qualifications; individual } \\
\text { adjustment of the form of support to the needs } \\
\text { of the teachers; analysis of the scope of } \\
\text { qualifications offered within the courses; } \\
\text { confirmation of acquisition of qualifications } \\
\text { with proper documents, e.g. certificates; } \\
\text { payment for exams; possibility of undergoing } \\
\text { internships or trainings instead of the courses; } \\
\text { possibility of financing commutes and } \\
\text { accommodation for the supported teachers; } \\
\text { career counselling for teachers; an offer for } 371 \\
\text { teachers; }\end{array}$ \\
\hline $\mathrm{G}$ & $\begin{array}{l}\text { Patronage of the } \\
\text { Poznań University of } \\
\text { Technology }\end{array}$ & $\begin{array}{l}\text { granted to student forms which meet the criteria } \\
\text { stipulated in the regulations; for example, the } \\
\text { benefits from the support for forms and schools } \\
\text { include: the school's right to publicize } \\
\text { information about the patronage of the Poznan } \\
\text { University of Technology, giving the students } \\
\text { information materials on education at the } \\
\text { faculties of the Poznan University of } \\
\text { Technology in the fields of study related to the } \\
\text { profession they are learning; ongoing } \\
\text { information about the events organized at the } \\
\text { university; posting interesting materials } \\
\text { concerning the university on the e-learning } \\
\text { platform; facilitating contact of Patronage forms } \\
\text { with scientific circle students at the Poznań } \\
\text { University of Technology; support for the } \\
\text { students about career counselling; informing } \\
\text { employers about outstanding students of the } \\
\text { patronage forms; providing the students with } \\
\text { multimedia materials provided by the faculties } \\
\text { of the Poznań University of Technology on the } \\
\text { e-learning platform. }\end{array}$ \\
\hline
\end{tabular}


$1^{\text {ST }}$ INTERNATIONAL SCIENTIFIC CONFERENCE $\gg$ TEACHING METHODS FOR ECONOMICS AND BUSINESS SCIENCES«

M. Szafrański, M. Goliński, E. Wiecek-Janka, M. Graczyk-Kucharska \& M. Spychała:

Nonformal Activities for the Improvement of the Development of Vocational

Competences - the Polish Example

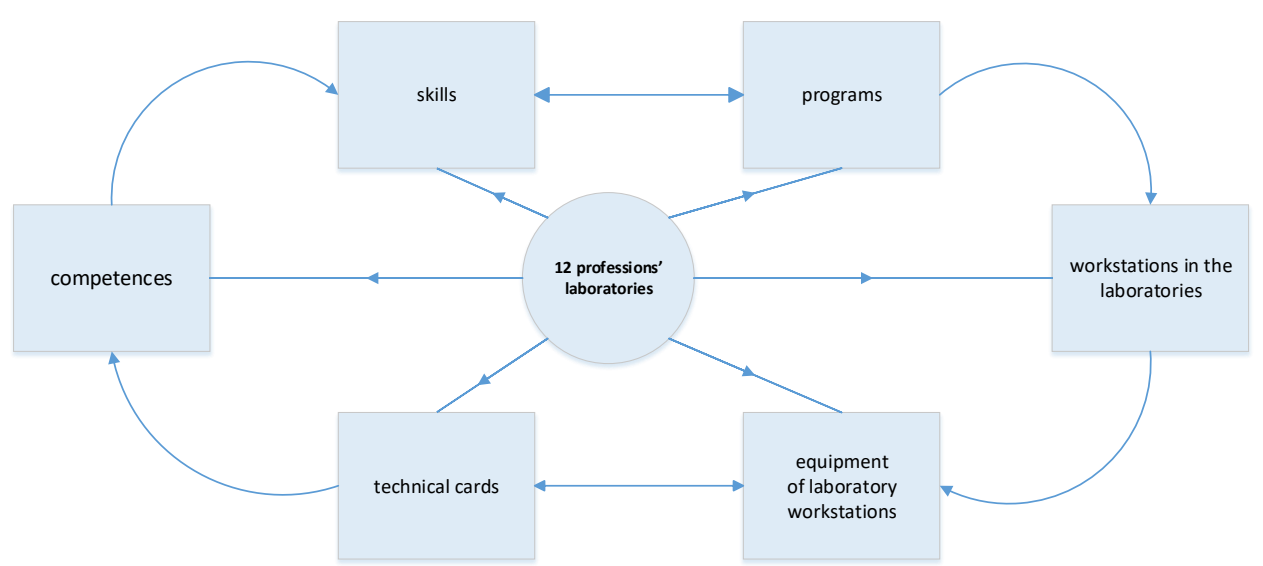

Figure 3: Preparation scheme for additional specialist classes in the laboratories under the project

The activities described in Table 1 are interrelated within processes. A model example has been presented in Figure 4.

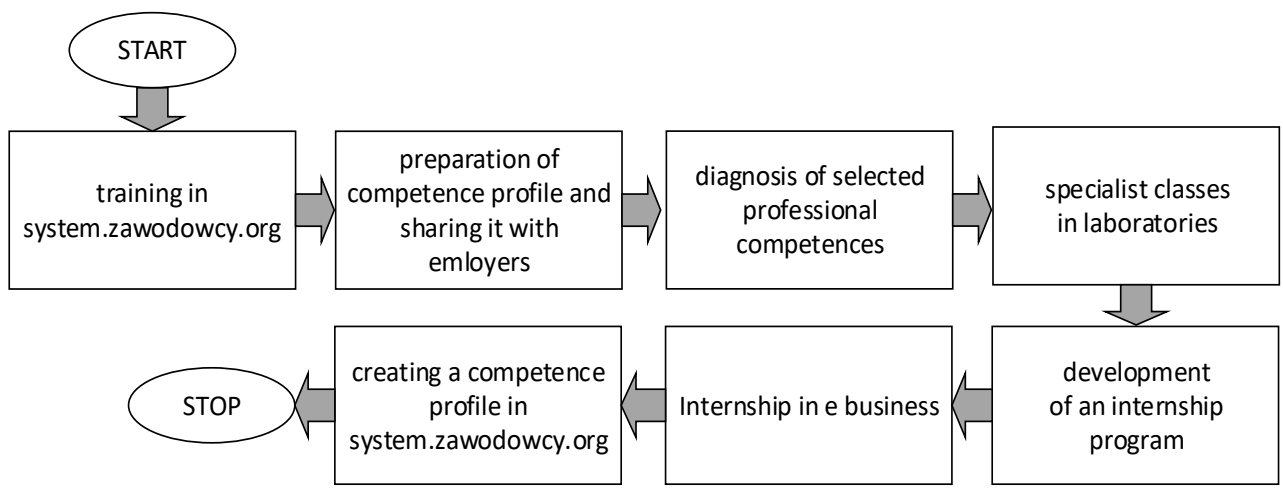

Figure 4: An example of the process of activities in CZ BIS-ZW project - support for a student of an upper secondary school of technical education (own study)

\section{$5 \quad$ Summary}

As it was shown in the article, at the moment the issue of developing professional competences is very popular but, unfortunately, the activities carried out in that respect are often unorganized and the absence of a systemic approach reduces the effectiveness of their results. 
M. Szafrański, M. Goliński, E. Wiecek-Janka, M. Graczyk-Kucharska \& M. Spychała: Nonformal Activities for the Improvement of the Development of Vocational Competences - the Polish Example

Formal vocational learning which should be the base for acquiring competences needed to perform future professional tasks is largely detached from the actual needs of the employment market, inflexible (lethargic and fossilized) and often subordinated to local short-term goals. The absence of any coherence between separate levels of vocational learning and insufficient exchange of information between the employment market and education centres about their mutual needs and potentials also strengthens the negative image of formal learning. Various supporting initiatives are being undertaken due to the key importance of vocational learning in the development of the economy - they are mainly information processes on the employment market but at the same time they integrate the activities of entities responsible for the development of economic initiatives in the scale of the region (or the country) and the development of education (particularly vocational learning at the upper secondary and higher education level). The Time of Professionals initiative which was discussed in the article is an example of nonformal activities for the improvement of the development of vocational competences. By connecting separate entities on the employment and education market via a system and tools, solutions such as Time of Professional are an efficient attempt at adjusting vocational education to the actual needs of employers with respect to professional competences. The scale of the solution and its results (past trainings, internships, number of users of system.zawodowcy.org) confirm that there is a need for such solutions not only in the region but the whole country as well.

\section{References}

Branowska A., Siemieniak P., \& Spychała M. (2012). Zarzadzanie kompetencjami w tradycyjnych i nowoczesnych organizacjach. Poznań: Wydawnictwo Politechniki Poznańskiej.

Duh, M., Letonja, M., \& Vadnjal, J. (2015). Educating succeeding generation entrepreneurs in family businesses - The case of Slovenia. Rijeka: InTech.

Duh M., \& Štrukelj T. (2011). The integration and requisite holism of the enterprises' governance and management as preconditions for coping with global environmental changes. Acta Polytechnica Hungarica, 8(1), 41-60.

Belak J., \& Hauptman L. (2011). Integral management approach: Business ethics and tax accounting as important enterprise success factors. African Journal of Business Management, 5(35), 13449-13509. Retrieved from http://www.academicjournals.org/AJBM

Filipowicz, G. (2000). Pracownik wyskalowany czyli metody i narzędzia pomiaru kompetencji. Personel 1(7). Warszawa.

Kocór M., \& Strzebońska A. (2014). Zapotrzebowanie na pracowników. Warszawa: PARP.

Kossowka, M., Sołtysińska, I. (2002). Szkolenia pracowników a rozwój organizacji. Kraków: Oficyna Ekonomiczna.

Maslowski, R., Breit, H., Eckensberger, L., \& Scheerens, J. (2009). A conceptual framework on informal learning of active citizenship competencies. In J. Scheerens, (Ed.), Informal learning of active citizenship at school: an international comparative study in seven European countries (pp.11-24). Dordrecht: Springer Science \& Business Media B.V. 
$1^{\text {ST }}$ InTERnATIONAL SCIENTIFIC CONFERENCE $\gg$ TEACHING METHOdS FOR ECONOMICS AND BUSINESS SCIENCES «

M. Szafrański, M. Goliński, E. Wiecek-Janka, M. Graczyk-Kucharska \& M. Spychała:

Nonformal Activities for the Improvement of the Development of Vocational

Competences - the Polish Example

Matusiak M. (2015). Regionalna Strategia Innowacji dla Wielkopolski na lata 2015-2020. Departament Gospodarki Urzędu Marszałkowskiego Województwa Wielkopolskiego w Poznaniu. Poznań.

Minister Rozwoju (2016). Wytyczne $w$ zakresie realizacji przedsięwzięć z udziałem środków Europejskiego Funduszu Społecznego w obszarze edukacji na lata 2014-2020. Warszawa.

Ministerstwo Rozwoju Regionalnego. (2012). Strategia rozwoju kraju 2020. Załącznik do uchwały Rady Ministrów z dnia 25 września 2012 roku. Warszawa.

Petrikova K., Borsekova K., \& Vanova A., (2016). Universities and their role in the development of multicultural environment. Éducation et Dialogue Interculturel, 33.

Pfeiffer, A. (Ed.) (2012). Szkoły i pracodawcy - razem ku lepszej jakości kształcenia zawodowego: materiały na konferencję: 11 października 2012. Warszawa: KOWEZiU.

Rostowski, T. (2002). Kompetencje jako jakość zarzadzania zasobami ludzkimi. Jakość zasobów firmy. Kultura, kompetencje, konkurencyjność. Warszawa: Wydawnictwo Poltext.

Spychała M., (2013). Kompetencje zawodowe menedżera przyszłości w wielkopolskim sektorze komunalnym. Kierunki ewolucji zachowań organizacyjnych. Acta Universitatis Lodziensis, Folia Oeconomica, 283, 185-198.

Spychała M., \& Matejun M. (2015). Badanie ocen wybranych kompetencji menedżerskich studentów WOiZ Politechniki Łódzkiej. Marketing i Rynek, 5, 1274-1293.

Straka, G. A. (2002). Valuing learning outcomes acquired in non-formal settings. In W. J., Nijhof, A. Heikkinen, L. F. M. Nieuwenhuis (Eds.), Shaping flexibility in vocational education and training (pp. 149-166). Dordrecht: Kluwer Academic Publishers.

Szafrański M. (2011). Wielkopolski system monitorowania i prognozowania w zakresie kształcenia zawodowego - innowacja w regionie. Poznań: Wydawnictwo Politechniki Poznańskiej.

Szafrański M. (2014). Laboratoria praktyk jako narzędzie wspomagające akcelerację dyfuzji wiedzy technicznej $\mathrm{w}$ przedsiębiorstwach. Pomiędzy zarządzaniem procesami edukacyjnymi a rynkiem pracy, 15 (8 Part III), 75-89.

Szafrański M. (2015a). Acceleration of educating as an external factor supporting preventive and improving actions in businesses. Procedia Manufacturing, 3, 4948-4955.

Szafrański M. (2015b). Praktyki zawodowe - narzędzie obniżania kosztów w przedsiębiorstwach. Przegląd Organizacji, 1, 29-35.

Szafrański M. (2015c). Zarządzanie akceleracją tworzenia zasobów wiedzy w przedsiębiorstwach. Poznań: Wydawnictwo Politechniki Poznańskiej.

Szafrański M., Ganowicz M., \& Goliński, M. (2016). Rozwój społecznej odpowiedzialności biznesu w sieci edukacyjno-gospodarczej. In J. Ejdys (Ed.) Społeczna odpowiedzialność $i$ zrównoważony rozwój w naukach o zarządzaniu.Aspekty teoretyczne i aplikacyjne (pp. 99114). Toruń: Wydawnictwo "Dom Organizacji”.

Szafrański M., Goliński M. (2015a). Monitoring demand for professional skills in SMEs of the Wielkopolska region. In A. Dunay (Ed.) Management, leadership and strategy for SME's competitiveness (pp. 73-77). Godolo: Szent Istvan University Publishing House. doi: 10.17626/dBEM.ICoM.P00.2015.p014

Szafrański, M., \& Goliński, M. (2015). System for Professionals-monitoring employers' demands for key competences in Wielkopolska. In X. Zhuang (Ed.) Recent Advances in Computer Science; Proceedings of the 19th International Conference on Computers (pp. 184-191). Zakhyntos, Greece

Szafrański, M., Goliński, M., \& Grupka, K. (2014). Akcelerator Wiedzy $\quad$ Technicznej®projektowanie przyszłości. Zeszyty Naukowe Wydziału Elektrotechniki i Automatyki Politechniki Gdańskiej, (37), 81-84. 
M. Szafrański, M. Goliński, E. Wiecek-Janka, M. Graczyk-Kucharska \& M. Spychała: Nonformal Activities for the Improvement of the Development of Vocational Competences - the Polish Example

Urząd Marszałkowski Województwa Wielkopolskiego. (2015). Szczegółowy opis osi priorytetowych programu operacyjnego (uszczegółowienie WRPO 2014+). Poznań.

Whiddett, S., \& Hollyforde, S. (2003). Modele kompetencyjne w zarządzaniu zasobami ludzkimi. Kraków: Oficyna Ekonomiczna.

Woodruffe, C. (2003). Ośrodki oceny i rozwoju. Kraków: OE

Zaręba P., Kępczyk R., Misztal J., Hadrian M., Biernat A. (2013). Wspótpraca szkót zawodowych z pracodawcami.Przykładowe rozwiazania. Warszawa: KOWEZiU.

Zarząd Województwa Wielkopolskiego. (2012). Wielkopolska 2020. Zaktualizowana strategia rozwoju województwa wielkopolskiego do 2020 roku. Załącznik do Uchwały NR XXIX/559/12 Sejmiku Województwa Wielkopolskiego z dnia 17 grudnia 2012 roku, Zarząd Województwa Wielkopolskiego. Poznań.

Zarząd Województwa Wielkopolskiego. (2014). WRPO 2014+. Wielkopolski Regionalny Program Operacyjny na lata 2014-2020, Poznań. 


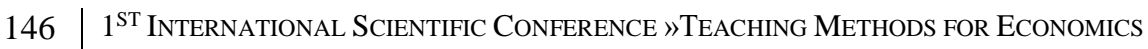
AND BUSINESS SCIENCES« 


\title{
Brainstorming Method for Developing Students' Transversal Skills
}

\author{
TJAŠA ŠTRUKELJ
}

\begin{abstract}
In business practice, employees need several transversal skills, e.g. entrepreneurship, creativity, communicativeness and teamwork. To be these skills more developed and thus to assure students to get their first job faster, faculty teachers may use several teaching methods. To accelerate transversal skills, members of the University of Maribor, Faculty of Economics and Business (members of the Department of Strategic Management and Company Policy), developed a teaching process model, which includes three selected teaching methods. One among them is the Brainstorming method, introduced in this article. Although well known, it has been a subject of the development, so in this article is explained a different version of this method.
\end{abstract}

Keywords: - brainstorming method - transversal skills $\cdot$ transversal competences $\bullet$ students $\bullet$ practical training •

Correspondence Address: Tjaša Štrukelj, Ph.D., Assistant Professor, University of Maribor, Faculty of Economics and Business, Razlagova 14, 2000 Maribor, Slovenia, e-mail: tjasa.strukelj@um.si. 
$1^{\text {ST }}$ InTERnATIONAL SCIENTIFIC CONFERENCE $»$ TeACHING METHOdS FOR ECONOMICS AND BUSINESS SCIENCES«

T. Štrukelj: Brainstorming Method for Developing Students’ Transversal Skills

\section{$1 \quad$ Introduction}

In the frame of the Erasmus+ co-funded project 'The acceleration method of development of transversal competences in the students' practical training process' (Accelerate transversal competences, 2017), eight project partners developed innovative pedagogical processes for accelerating the development of transversal skills/competences of students (i.e. entrepreneurship, creativity, communicativeness and teamwork) by enhancing and improving the use of practical training. Project partners defined transversal skills/competences as "a combination of knowledge, skills and attitudes appropriate to situations necessary to meet social aims. They offer added value in relation to employment, social cohesion (European pact for youth), which explains the significance of lifelong learning as regards adaptability to change and social inclusion" (ibid.). In the frame of this project, the members of the University of Maribor, Faculty of Economics and Business (members of the Department of Strategic Management and Company Policy) (UM FEB), developed a teaching process model, which includes three selected teaching methods (out of 85): Brainstorming, Teamwork and Case study (Table 1).

Table 1: Selection of the practical training methods for designing process model UM FEB based on the Matrix of the dependencies between practical teaching methods and an increase in students' transversal skills

\begin{tabular}{|c|c|c|c|c|c|c|c|c|c|}
\hline $\begin{array}{l}\text { No. of the } \\
\text { method in } \\
\text { the } \\
\text { process }\end{array}$ & $\begin{array}{l}\text { Name of } \\
\text { practical } \\
\text { teaching } \\
\text { method }\end{array}$ & Quartile & $\begin{array}{l}\text { Rank of } \\
\text { the } \\
\text { method } \\
\text { in matrix }\end{array}$ & $\begin{array}{l}\text { Entre- } \\
\text { preneur- } \\
\text { ship }\end{array}$ & $\begin{array}{l}\text { Crea- } \\
\text { tivity }\end{array}$ & $\begin{array}{l}\text { Commu- } \\
\text { nicati- } \\
\text { veness }\end{array}$ & $\begin{array}{l}\text { Team- } \\
\text { work }\end{array}$ & $\begin{array}{l}\text { Group of } \\
\text { methods }\end{array}$ & $\begin{array}{c}\text { Impact of the } \\
\text { method on } 4 \\
\text { transversal } \\
\text { competences }\end{array}$ \\
\hline 1. & $\begin{array}{c}\text { Brainstor- } \\
\text { ming }\end{array}$ & 1 & 3 & 0.97 & 1.25 & 0.96 & 0.94 & $\begin{array}{l}\text { Problem- } \\
\text { solving } \\
\text { methods }\end{array}$ & 4.11 \\
\hline 2. & Teamwork & I & 15 & 0.65 & 0.68 & 1.02 & 1.26 & $\begin{array}{l}\text { Problem- } \\
\text { solving } \\
\text { methods / } \\
\text { Activating } \\
\text { methods }\end{array}$ & 3.60 \\
\hline 3. & Case study & II & 24 & 1.03 & 1.00 & 0.60 & 0.82 & $\begin{array}{l}\text { Problem- } \\
\text { solving } \\
\text { methods / } \\
\text { Activating } \\
\text { methods }\end{array}$ & 3.44 \\
\hline
\end{tabular}

Source: Based on Matrix (2016).

Project research results are available on the project internet site $^{1}$ or on the UM FEB's Institute of Management Development internet site ${ }^{2}$.

This paper focuses on brainstorming as one of the practical teaching methods. After this introduction (section 1), the concept of brainstorming as a practical teaching method is introduced in section 2, followed by the explanation of the brainstorming technique at UM FEB (section 3), and a possible development of the brainstorming technique at UM 
T. Štrukelj: Brainstorming Method for Developing Students’ Transversal Skills

FEB is presented in section 4. A recommended use of this technique at UM FEB is introduced in section 5. Some conclusions are given in section 6 .

\section{$2 \quad$ Brainstorming as practical teaching method}

One of practical teaching methods selected for the testing process of developing transversal skills is definitely brainstorming. Brainstorming (Business Dictionary, 217) is a process for generating creative ideas and solutions through intensive and freewheeling group discussion. Every participant is encouraged to think aloud and suggest as many ideas as possible, no matter seemingly how outlandish or bizarre. Analysis, discussion, and/or criticism of the ideas aired are allowed only after the brainstorming session is over and evaluation session begins.

Brainstorming (MindTools, 2017) combines an informal approach to problem solving with lateral thinking. It encourages people to create thoughts and ideas that can, at first, seem fuzzy (out of their normal ways of thinking). Some of them can be crafted into new, creative solutions, while others can spark even more ideas. During brainstorming sessions, people should avoid criticizing or rewarding ideas. This opens up possibilities and breaks down incorrect assumptions about the problem's limits. Judgment and analysis at this stage stunts idea generation and limits creativity. Ideas are evaluating at the end of the session. Brainstorming provides a free and open environment which encourages everyone to participate. When used during problem solving, brainstorming brings team members' diverse experience into play. It increases the richness of ideas explored, which means better solutions to the problems. Brainstorming helps team members bond, as they solve problems in a positive, rewarding environment. While brainstorming can be effective, it's important to approach it with an open mind and a spirit of non-judgment. If participants don't do this, the number and quality of ideas plummets, and morale can suffer.

\section{Brainstorming at University of Maribor, Faculty of Economics and Business}

In Slovenia, at the University of Maribor, the Faculty of Economics and Business (UM FEB), faculty teachers usually use somewhat modified Alex Faickney Osborn's (Osborn, 1953 and later) brainstorming technique. This extraordinary means of creative thinking is, according to UM FEB former full prof. dr. Janko Kralj, carried out as follows (Kralj, 1995, p. 378, supplemented with the last bullet point):

- Participants participate in small groups of about 5-12 people, they are separated from other groups and have no contact with other groups. They must be well informed about the problem and they should 'warm up' to solve the problem.

- First 20 minutes of creative thinking process, group members collect ideas as follows. Each participant says anything he or she can think of related to the problem; also, he or she may present unusual ideas. No criticism or mockeries 
are allowed and the authorship of ideas is ignored. All ideas presented are recorded transparently and in detail.

- In the next 20 minutes, students devote time to idea maturing. Each participant is considering the ideas collected in the first 20 minutes.

- After that, the participants deal with the ideas - they either transform unusual ideas into useful ones or discarded them completely; they combine the ideas and also prepare a list of ideas, and after that, they prioritize them.

- The next step is to critically discuss the ideas that were given the highest priority and other ideas in the role of the devil's advocate. It is of key importance that extremely sceptical views on the proposals are presented so as to promote critical thinking. This process is known as 'reversal brainstorming' - how an idea fails. In this way, just good ideas that are worthy of further study remain for further consideration.

- Participants need to combine and improve the remaining good ideas that remain - as suggested by the slogan ' $1+1=3$ ', they need to find a synergy among them. To do this, some faculty teachers (e.g. assist. prof. dr. Tjaša Štrukelj) encourage participants to combine the brainstorming method with Mulej's (1974 and later; Mulej et al., 2000; 2013) Dialectical Systems Theory, which addresses synergy, interdependency and holistic approach.

The brainstorming approach to finding solutions combined with a systemic approach was encouraged at FEB also within the workshop delivered by Kovačič (2015), where the aim was to develop the skills of systems thinking. Here, gamification was used since this approach is becoming very popular for trying to solve specific business challenges. The gamification element was applied in the form of rewarding. That is, the participants were evaluated according to the principle 'the more ideas - the higher the score'. In the first phase, the participants focused on the addressing all viewpoints of a given challenge that were essential in their view. From all the viewpoints identified, they then chose a few which they considered significant. In the second phase, the participants focused on dealing with all significant relationships (linkages) between the selected viewpoints. In the end of this phase, they selected a few significant relationships between the viewpoints out of all the identified relationships. This was followed by the third phase in which the participants looked for the synergy effects between the selected significant viewpoints and their significant relationships (linkages) - they wrote one single most important statement that could represent an important development opportunity for the enterprise (as an answer to a specific business challenge that was solving). That is, in the context of gamification, the participants received a request from the enterprise director to solve a specific problem. For example, in their solution, they had to highlight how the enterprise will be able to comply with the request of the key value of corporate social responsibility $-0 \%$ waste in production in 2020 . The director has requested products which will be sustainable and developmental solutions which will support social responsibility. By raising awareness of the need for systemic thinking, the students were able to get more holistic solutions that included all and only the essential viewpoints, the significant relationships (linkages) between them and synergy effects. 
T. Štrukelj: Brainstorming Method for Developing Students’ Transversal Skills

At the University of Maribor, Faculty of Economics and Business (UM FEB), the brainstorming method is used within full-time and part-time study subjects at both firstand second-cycle levels. As an example of the use of diverse practical teaching methods (including brainstorming) in practical classes within a business subject (Belak et al., 2016, pp. 78-79, supplemented), we describe here the course 'Enterprise Policy and Strategic Management'. It is delivered to the students of the third (i.e. last) year of professional undergraduate study programme. We describe this example from our personal experiences perspective. Usually, practical teaching process in this subject starts with an empowering example with the aim to develop appropriate values, culture and ethics among students. In this subject, students learn how to make decisions as owners/governors and/or top managers of an enterprise or other organisation. To teach responsible values, appropriate culture and ethical attitudes, the teacher and the students first discuss their values, culture and ethics through stories with a moral lesson. A moral precept and the importance of moral behaviour for every person in the world are discussed. This is followed by a revision of essential theoretical starting points needed for work in the each time specific teaching process together with examples from practice. At this stage, 15-20 minutes are devoted to brainstorming, with students delivering ideas of examples from practice associated with this specific subject. During the teaching process, students learn how to choose a large amount of cases, even bizarre ones, and their ideas complement also other students. The teacher directs students to connect practical examples provided by students with content of the course. At the end of this process, the presented examples are critically assessed and the particularly useful ones are highlighted. In this way, students learn to integrate theory with practice. After that, the students are divided into an even number of groups and they receive their tasks. Each of the two groups that form a pair has the same task, but this task is different from the task of other 'two group pairs'. Therefore, students usually solve two or three different tasks (problems of two or three different enterprises). This, of course, depends on the number of groups (e.g. 4 groups -2 tasks; 6 groups -3 tasks). After they confirm that they understand their tasks, students use teamwork method to solve these tasks. When the time allocated for teamwork ends, students report their solutions to their colleagues. Since one of the aims of the subject 'Enterprise Policy and Strategic Management' is for students to learn how to make decisions as enterprise owners or top managers, the solution of each group solving the same task may be different although both can be correct. A higher mark is given to the group, which gives a correct solution (i.e. the solution based on correct theoretical backgrounds transferred to a concrete example/task at hand), which must also be well justified (i.e., students present better arguments). Therefore, the students develop a group discussion about the solution found, which is better also because of using brainstorming method at the beginning of the tutorials.

\section{Possible development of brainstorming at University of Maribor, Faculty of Economics and Business}

According to our further analysis, there are several possible ways in which further stages of using brainstorming at University of Maribor, Faculty of Economics and Business (UM 
FEB) should/could be conducted so that an increase in transversal competences, including skills making up these competences, could occur as quickly as possible.

UM FEB retired full prof. dr. Štefan Ivanko suggests solo brainstorming (Ivanko, 1996, p. 71), 6-3-5 brainwriting (also 635 Method, Method 635) (ibid., p. 71), and brainwriting pool (ibid., p. 73). Here, we provide only a brief explanation of each method:

- Solo brainstorming (Ivanko, 1996, p. 71) is used by individual by himself/herself. One is relaxed and can confidently produce ideas which he/she later evaluates. In this methods, group processes of course do not apply. Several studies have shown (MindTools, 2017) that individual brainstorming produces more - and often better - ideas than group brainstorming. This can occur because groups are not always strict in following the rules of brainstorming. Mostly, though, this happens because people pay so much attention to other people that they do not generate ideas of their own - or they forget these ideas while they wait for their turn to speak. This is called 'blocking'. When you brainstorm on your own, you do not have to worry about other people's egos or opinions, and you can be more free and more creative. However, you may not develop ideas as fully when you are on your own, because you do not have the wider experience of other group members to draw upon. In group brainstorming, you can take advantage of the full experience and creativity of all team members. When one member gets stuck with an idea, another member's creativity and experience can take the idea to the next stage. Participants can develop ideas in greater depth with group brainstorming than individual person can with individual brainstorming.

- 6-3-5 Brainwriting (or 635 Method, Method 635) is a group-structured brainstorming technique (McNicholas, 2011) aimed at aiding innovation processes by stimulating creativity developed by Bernd Rohrbach (Rohrbach, 1968). In brief, it consists of 6 participants supervised by a moderator who are required to write down 3 ideas on a specific worksheet within 5 minutes; this is also the etymology of the methodology's name. The outcome after 6 rounds, during which participants swap their worksheets passing them on to the team member sitting at their right, is 108 ideas generated in 30 minutes. The technique is applied in various sectors but mainly in business, marketing, design, writing as well as everyday real life situations (McNicholas, 2011). On each worksheet that participants receive (Ivanko, 1996, p. 72), they must attribute three ideas. Prior to this, they should read already written ideas and try new ideas associated with them, transform them or used otherwise.

- The brainwriting pool is a brainwave technique, which is also a group brainstorming method. It was first described by Helmut Schlicksupp (19432010) in 1975 as creative ideas for enterprises (Schlicksupp, 1975). This technique of creative co-operation (Ivanko, 1996, p. 73) is similar to the method 635, but participants do not need to forwards the ideas written on the worksheet in a certain order. Participants are seated at the table. In the middle of the table is a bunch of worksheets, which may be empty or they could have 
T. Štrukelj: Brainstorming Method for Developing Students’ Transversal Skills

written a few ideas. This bunch of worksheets is called 'pool'. When a participant records his ideas on a worksheet, he/she deposits it in the middle of the table. At the same time he/she takes a new worksheet in which another participant has already written a few ideas; he/she has to read these ideas and try to add new ones. When he/she has no more ideas, he/she returns the worksheet to the middle of the table and takes a new one. Participants repeat this as until they cannot produce new ideas any more. The evaluation of ideas follows later. When evaluating, all ideas can be classified into three groups: (1) the useful; (2) could be useful, but need to be further developed; and (3) unusable. Ideas can also be grouped according to their similarity; we can then make the evaluation within each group. In assessing the value of ideas, we must take into account the realization that the most popular ideas are usually not the best. The most creative ideas because of their originality, strangeness or shocking effect usually do not attract other participants.

You often get the best results by combining individual and group brainstorming (MindTools, 2017).

\section{Recommended use of brainstorming at University of Maribor, Faculty of Economics and Business}

In this section, we describe the way in which brainstorming method will be used in the testing process, which is described in the present document (compatibility of the description with the point 2 is ensured). The method will be used as a part of the subject "Management of small and medium-sized enterprises" in a group of first-cycle students at the University of Maribor, Faculty of Economics and Business (UM FEB), full-time studies, $6^{\text {th }}$ semester, elective subject for all students of the program (the subject taught during $30 \mathrm{hrs}$. of lectures and $30 \mathrm{hrs}$. of tutorials). Two meetings are planned (week-long interval between meetings is recommended).

\section{Meeting 1 (45 minutes):}

1. Introducing students to the content of the Erasmus + project "The acceleration method of development of transversal competences in the students' practical training process" (10 minutes).

2. Introducing students to the competencies to be developed in the process (entrepreneurial skills, communicativeness, creativity and teamwork skills) (10 minutes).

3. Introducing students to the testing process of developing transversal skills as part of practical training (including the planned implementation - on which meetings and how long will be the performance of this process carried out) (15 minutes).

4. Implementation of the survey "Questionnaire for the assessment of the evaluation of transversal skills level of the students in practical teaching process (the level of possessed skills)" (10 minutes). 
Meeting 2 ( 3 hours and 15 minutes pause).

The following steps are taken:

1. Comfortable meeting environment and the resources needed are prepared before the class (i.e. post-it notes, colour sheets and pens of different colours, flip chart or the whiteboard) (5-10 minutes).

2. Students are acquainted with general rules and the application of brainstorming and are given the criteria which are to be met. (25 minutes).

3. Students are then introduced to the entrepreneur. With the entrepreneur's help, the students are to solve the problem from practice (and the entrepreneur will play an active role during the whole process of brainstorming) (5 minutes).

4. The introduction of the entrepreneur (5 minutes).

5. Students are given the problem from practice and they 'warm them': Clearing on the problem to be solved; the problem is related to the success factors in the start-up and the development of the enterprise. Students have to be well informed about the problem (10 minutes)!

6. Students individually identify various viewpoints to solve the problem. They have to have enough quiet time to write down as many ideas as they can. The ideas are recorded on the colour sheets; each student has another colour of the sheet; each student writes 'Viewpoints' in the upper left corner of the sheet (5 minutes).

7. Teacher writes the number of collected ideas for each student on the flip chart or the whiteboard (3 minutes).

8. Students pass their colour sheet to the student on their left. All students are required to read the already written ideas and again individually identify (and write down) various viewpoints to solve the problem. They are encouraged to try new ideas associated with the already written ideas, transform them or otherwise use them. They have to have enough quiet time to write down as many ideas as they can. The ideas are recorded (version of 6-3-5 brainwriting) (5 minutes).

9. Students get their colour sheets back. They again try to find as many new viewpoints to solve the problem as possible. The idea is thus maturing. They have to have enough quiet time to write down as many ideas as they can. The ideas are recorded (5 minutes).

10. Teacher writes the number of additionally collected ideas for each student on the flip chart or the whiteboard. The 'winner' is the student with the highest number of collected ideas ( 3 minutes).

11. Students individually (and independently from one another) identify $3-5$ viewpoints to solve the problem which they consider as the most important ones (and circle them with a different colour pen) ( 2 minutes).

12. Students get the second sheet of paper in the same colour. They individually (and independently from one another) identify various relationships (linkages) between the selected viewpoints. They need to be given enough quiet time to find and write down as many relationships (linkages) as they can. The relationships (linkages) are recorded on the colour sheets; each student writes 'Relationships (linkages)' in the 
upper left corner of the sheet and below that he records "The most important viewpoints selected: viewpoint 1 , viewpoint $2, \ldots$, viewpoint n" ( 5 minutes).

13. Teacher writes the number of collected relationships (linkages) between the selected viewpoints for each student on the flip chart or the whiteboard (3 minutes).

14. Students pass their colour sheet to the student on their right. All students are required to read the already written relationships (linkages) and again individually (and independently from one another) identify various relationships (linkages) between the viewpoints their colleague has selected as the most important ones to solve the problem. They should try new ideas associated with the already written ideas, transform them or otherwise use them. They have to have enough quiet time to write down as many ideas as they can. The ideas are recorded (version of 6-3-5 brainwriting) (5 minutes).

15. Students get their colour sheets back. They again try to find as many as possible relationships (linkages) between the viewpoints to solve the problem. The idea is maturing. They need to be given enough quiet time to write down as many relationships (linkages) between the viewpoints as they can. The ideas are recorded (5 minutes).

16. Teacher writes the number of additionally collected relationships (linkages) between the viewpoints for each student on the flip chart or the whiteboard. The 'winner' is the student with the biggest number of collected relationships (linkages) between the viewpoints they pointed out to solve the problem is ( 3 minutes).

17. Students individually (and independently from one another) identify 3-5 most important relationships (linkages) between the viewpoints which they pointed out to solve the problem and circle them with a different colour ( 2 minutes).

18. Students get the third sheet of paper in the same colour. They independently from each other identify the synergies among 3-5 most important circled significant relationships (linkages) between the viewpoints they pointed out to solve the problem (from selected relationships between the selected viewpoints students write a sentence that best exemplifies viewpoints and links between them, which they consider to be most important for the solution of the problem to be solved). In such a way we get their personal solutions to the problem. The synergies between relationships (linkages) are recorded on the colour sheets; each student on the upper left corner writes "Synergies" and below that he records "The selected most important relationships (linkages): relationship (linkage) 1, relationship (linkage) 2, $\ldots$, relationship (linkage) n" (5 minutes).

19. Pause and idea maturing. Each participant is considering the collected ideas (viewpoints, significant relationships (linkages), synergies and keyword (keyword phrase)) (15 minutes). The rest of the process could be organised as a Meeting 3; when so, a 10 minute long conclusions - teacher summarising brainstorming process and key points till so far is needed before ending (before pause) and 10 minutes long starting "warm-up" in sense of summarising work so far is needed after pause.

20. Students pass their colour sheet, on which writes "Synergies" on the upper left corner, in the middle of the table. This bunch of worksheets is called "pool". Each student takes one colour sheet that is not his and read already written synergies. Independently from each other students on the basis of written phrases (synergies) 
$1^{\text {ST }}$ INTERNATIONAL SCIENTIFIC CONFERENCE $\gg$ TEACHING METHOdS FOR ECONOMICS AND BUSINESS SCIENCES«

T. Štrukelj: Brainstorming Method for Developing Students' Transversal Skills

write a keyword (keyword phrase), which in their opinion best describes written synergy. Then they return the colour sheet to the middle of the table and take a new one. Students repeat this until they can produce ideas. They have to have enough quiet time to write down as many keywords (keyword phrases) as they can. The ideas are recorded (version of brainwriting pool technique) (20 minutes).

21. Students take their colour sheet back and independently from each other subjectively identify one keyword (keyword phrase) most important for them to solve the problem (and circle keyword (keyword phrase) with another colour). Students write down the selected keyword (keyword phrase) on the post-it note (3 minutes).

22. Working as a group: Students share their keywords (keyword phrases) and attach post-it notes on the flip chart or whiteboard, in a line (3 minutes).

23. Analysis 1: Students are governing ideas under the guidance of teacher: Unusual ideas they transform into useful; they combine the ideas and in such a way seek priority ideas. Group discussion opens building on others ideas, which is perhaps most valuable viewpoint of group brainstorming. Teacher is guiding the discussion and takes care that all students participate. Creativity ideas are welcomed and no criticizing is allowed. New ideas are recorded (also on the post-it notes) (10 minutes).

24. Analysis 2: Students criticize priority ideas in the role of devil's advocate. With extremely sceptical views on the proposals is necessary to promote critical thinking. This is a reversal brainstorming: how an idea fails. Not all post-it notes stay on the flip chart or whiteboard, only priority ideas. In this way remain just good ideas that are worthy of further study (10 minutes).

25. Evaluation: Students evaluate the good ideas (that are still recorded on the flip chart or on the whiteboard) and to three in their opinion the best allocate points. They distribute points: (3) the most useful idea; (2) the second useful idea; and (1) the third useful idea that still gets points. Each student writes his evaluation on the flip chart or whiteboard. After the evaluation on the flip chart or whiteboard stay 3-5 selected extremely good ideas, which get the highest scores (10 minutes).

26. Students need to combine and improve 3-5 selected extremely good ideas, which get the highest scores and form a sentence or two representing their final proposal for a solution to the problem, which was solved. As suggested by the slogan "1+1=3" they need to find a synergy among 3-5 selected extremely good ideas (10 minutes).

27. Conclusion: "When managed well, brainstorming can help you generate radical solutions to problems. It can also encourage people to commit to solutions, because they have provided input and played a role in developing them" (MindTools, 2017). Discussion on the results and summarising the whole process (8 minutes).

28. The implementation of the survey Research methodology of the pace of an increase in competences during the implementation of training processes including selected practical teaching methods" (10 minutes).

The University of Maribor, the Faculty of Economics and Business members (members of the Department of Strategic Management and Company Policy) (UM FEB) are one of 
the partners the Erasmus+ project titled "The acceleration method of development of transversal competences in the students' practical training process". Other project partners are Poznan University of Technology (Poland) in the role of the coordinator of the project, Wroclaw University of Economics (Poland), Czestochowa University of Technology (Poland), Western Chamber of Industry and Commerce (Poland), Centria University of Applied Sciences (Finland), JEDU the Federation in Education in Jokilaasot (Finland) and Matej Bel University Banska Bystrica (Slovakia). The primary goal of the project is to elaborate and implement five innovative acceleration teaching process models with several teaching methods in each of them, for development of transversal skills of students. One of the teaching process models was developed by members of the University of Maribor, Faculty of Economics and Business (members of the Department of Strategic Management and Company Policy) (UM FEB). This teaching process model includes three selected teaching methods (out of 85): Brainstorming, Teamwork and Case study. In this article the Brainstorming method was introduced because by using this method, students can develop transversal skills (e.g. entrepreneurship, creativity, communicativeness and teamwork) very well, and the method is also easy to use.

\section{Notes}

1 http://www.awt.org.pl/erasmus/do-pobrania/?lang=en (see download/research)

\section{References}

Accelerate transversal competences (2017). The acceleration method of development of transversal competences in the students' practical training process. EU: Erasmus+ Programme. Retrieved March 31, 2017 from http://www.awt.org.pl/projekty/oprojekcie/?lang=en

Belak, J., Duh, M., \& Štrukelj, T. (2016). Practical teaching methods applied in higher education - Slovenian experiences. In Report O1: The report concerning applied teaching methods of transversal skills and methods of practical trainings. Prepared in the framework of the project "The acceleration method of development of transversal competences in the students' practical training process" (pp. 75-86).

Business Dictionary (2017). Brainstorming. WebFinance Inc. Retrieved from http://www.businessdictionary.com/definition/brainstorming.html

Ivanko, Š. (1996). Upravni praktikum I (Metodološki seminar). Ljubljana: Univerza v Ljubljani, Visoka upravna šola.

Kovačič, V. (2015). Izkustvena delavnica: Razvoj kompetenc sistemskega razmišljanja z igrifikacijo. EPF in družbena odgovornost (1.12. 2015). Maribor: Faculty of Economics and Business. Retrieved from http://www.epf.um.si/o-fakulteti/predstavitevfakultete/druzbena-odgovornost/do-dogodki/do-dogodkipodrobno/?tx_sfeventmgt_pievent $\% 5$ Bevent $\% 5 \mathrm{D}=118 \&$ tx_sfeventmgt_pievent $\% 5 \mathrm{Bactio}$ n\%5D=detail\&tx_sfeventmgt_pievent\%5Bcontroller\%5D=Event\&cHash=556899439265 ae $0543170 f 736 \mathrm{e} 28 \mathrm{e} 98 \mathrm{a}$

Kralj, J. (1995). Politika podjetja v tržnem gospodarstvu. Maribor: Ekonomsko-poslovna fakulteta.

Matrix (2016). Matrix of the dependencies between practical teaching methods and an increase in students' transversal competences. Prepared in the framework of the Erasmus+ project 
T. Štrukelj: Brainstorming Method for Developing Students' Transversal Skills

"The acceleration method of development of transversal competences in the students' practical training process". Retrieved March 28, 2017 from http://www.awt.org.pl/wpcontent/uploads/2016/09/Matrix-IO3-elaborating-steps-EN_5.pdf

McNicholas, C. (2011). Creativity and problem solving. COEUR-BCM, Business creativity module. RGU: Aberdeen Business School. Retrieved from https://is.vsfs.cz/el/6410/zima2012/E_CEP/2_BC_Lec_Creativity_not_hide_1_2011.pdf

MindTools (2017). Brainstorming: Generating many radical, creative ideas. Management Training and Leadership Training, Online. Retrieved from https://www.mindtools.com/brainstm.html

Mulej, M. (1974). Dialektična teorija sistemov in ljudski reki. Naše gospodarstvo, 21(3-4), 207212.

Mulej, M., Espejo, R., Jackson, M., Kajzer, S., Mingers, J., Mlakar, P., ... \& Vallée, R. (2000) . Dialektična in druge mehkosistemske teorije (podlage za celovitost in uspeh managementa). Maribor: Ekonomsko-poslovna fakulteta.

Mulej, M., Božičnik, S., Čančer, V., Hrast, A., Jurše, K., Kajzer, Š., ... Ženko, Z. (2013). Dialectical systems thinking and the law of requisite holism concerning innovation. Litchfield Park: Emergent Publications.

Osborn, A. F. (1953). Applied imagination: Principles and procedures of creative thinking. New York: Charles Scribner's Sons.

Rohrbach, B. (1969). Kreativ nach Regeln - Methode 635, eine neue Technik zum Lösen von Problemen. (Creative by rules - Method 635, a new technique for solving problems). Absatzwirtschaft 12, 73-53.

Schlicksupp, H. (1975). Grundlagen der ideenfindung und problemlösung. Darmstadt: Vogel Business Media. 


\title{
Selected Approach to Faculty's Ethical Decision-Making towards Building a Good Student Environment
}

\author{
TJAŠA ŠTRUKELJ
}

\begin{abstract}
Many human problems nowadays reflect unethical and socially irresponsible decision-making in the past and in the present. Individuals, groups, enterprises and other organizations as well as governments are responsible for social, animal and planet Earth survival. Although we are in the 21st century, our consciousness still needs the shift from independence to interdependence and towards more requisitely holistic approach. In this paper, we discuss enterprises in a broader sense (including all organizations) and introduce a selected ethical decisionmaking approach for them, with the proposed Code of Ethics to be realized within the teaching of economics and business subjects. Although enterprises have several possibilities to develop themselves towards more ethics and social responsibility, we research the mentioned approach which can be a useful tool for building a good student environment. In order to achieve the desired results, this approach must be supported with enterprise governance and resulting enterprise policy, strategic management, operative management and business practice innovation.
\end{abstract}

Keywords: • enterprise policy $\bullet$ strategic management $\bullet$ ethical decisionmaking $\bullet$ social responsibility $\bullet$ business education $\bullet$

Correspondence Address: Tjaša Štrukelj, Ph.D., Assistant Professor, University of Maribor, Faculty of Economics and Business, Razlagova ulica 14, 2000 Maribor, Slovenia, e-mail: tjasa.strukelj@um.si. 
$1^{\text {ST }}$ INTERNATIONAL SCIENTIFIC CONFERENCE $\gg$ TEACHING METHODS FOR ECONOMICS AND BUSINESS SCIENCES «

T. Strukelj: Selected Approach to Faculty's Ethical Decision-Making towards Building a Good Student Environment

\section{Introduction}

Our economy creates only some preconditions for well-being and happiness of people (Blanchflower \& Oswald, 2011; EC, 2011; Čančer \& Šarotar Žižek, 2015; Judge \& Kammayer-Mueller, 2011; Wu \& Wu, 2010; OECD, 2011). The innovation of planning and management criteria must, therefore, be oriented towards greater social responsibility and requisite holism (Dyck, 2011; EU, 2011; Hrast et al., ed., 2013; ISO, 2010; Motohashi et al., 2012; Mulej et al., 2013; Štrukelj \& Šuligoj, 2014; Wang \& Juslin, 2012). The process must lead towards enterprise ethics and socially responsible enterprise, as well (see e.g. Epstein, 2010; Madu \& Kuei, 2012; Rejc Buhovac \& Epstein, 2014; Wagner, 2012). Therefore, future social and economic development will require even more creativity and innovation, both technological and non-technological ones. New benefit for current and future generations should be, therefore, provided through enterprise policy (as a result of desired enterprise governance) innovation (Amman et al., 2011; Duh \& Štrukelj, 2011; Šarotar-Žižek et al., 2011; Štrukelj et al., 2012). One of possible modes of innovating enterprise policy implementation is achieving enterprise credibility through the Code of Ethics, which is the focus of our research. But we have to emphasize that none of the studied fields make sense when enterprises are not willing to innovate their enterprise policy - when its governance and management are not able to adapt to these new market conditions (for a previous version, see Štrukelj and Mulej (2014)); there is no conflict of interest).

In this article, we first research business ethics in decision-making. In section 2, we introduce interdependent approaches to enterprise's ethical decision-making: ethical routine decision-making, ethical analytical decision-making (according to the model, method, theory), and ethical intuitive decision-making (which happens in decisionmakers' sub-consciousness). In section 3, we introduce a practical viewpoint of the contents of routine ethical decision-making on the case of the FEB. Some conclusions are introduced in section 4 .

\section{Interdependent approaches to enterprise's ethical decision-making}

Ethical decision-making is not generally practiced as yet; otherwise, documents such as the ISO 26000 on social responsibility (ISO, 2010), etc., would not be needed; neither would the European Union's action plan on social responsibility be needed (EU, 2011). The moment of passing these documents says that ethics and social responsibility are supposed to help humans / humankind solve problems resulting from the decades of neoliberal economic theory and practice. The EU (2011) states this quite explicitly. Ethical decision- making is demanding when the manager, during the coordination of the interests of enterprise stakeholders, assesses the often opposing or incompatible values and chooses the right decisions (Možina et al., 2004, p. 397). Enterprises can implement enterprise ethics by ethical decision-making: there are different ways of ethical intuitive, analytical and routine decision-making that are interdependent (Tables 1-3). Routine decisions on ethical matters should be upgraded with analytical decision-making and analytical decision-making with intuitive decision-making. Ethical climate, which the 
author of this paper understands as the affection and willingness of enterprise stakeholders to promote enterprise ethics, often changes in the enterprise (Belak, Je. \& Mulej, 2009). Hence, enterprises implement enterprise ethics by active care and by regular measurement of enterprise ethics (Belak, Je. \& Milfelner, 2011).

Table 1: Interdependent approaches to enterprise's ethical decision-making, part 1 Ethical intuitive decision-making (i.e. happening in decision-makers' subconsciousness)

\begin{tabular}{|l}
\hline $\begin{array}{c}\text { Ethical intuitive decision-making (i.e. happening in decision-makers' sub- } \\
\text { consciousness) }\end{array}$ \\
\hline • provides creative decisions (which may be encouraged, but more difficult to \\
manage) \\
- is useful in conditions of partial information and risk \\
- often provides a rapid response to unforeseen events \\
- is strongly dependent on the knowledge, experience, values and level of moral \\
development of decision-maker \\
- provides advantages(creativity, commitment) as well as \\
disadvantages(thoughtlessness, the greater risk, the greater stress caused by ethical \\
dilemmas) \\
• is the foundation of knowledge about the possible philosophical and ethical models \\
as in analytical decision-making \\
- its foundation is the knowledge and consciousness of the reality; the decision \\
makers should attain the highest possible level of development regarding ethical \\
decision-making and moral operation (Tavčar (2002) speaks about the level of \\
personal ethical/moral development); mature human personality, upright and strong \\
people are needed* \\
•characteristics of the decision-maker: knowledge, experience, honesty, fairness, \\
self-esteem, rational assessment, confidence, creativity, temperance, responsibility, \\
conscience, perseverance, wisdom, no short-term and narrow-minded orientation* \\
•most appropriate for the level of enterprise policy* \\
•most commonly used by business owners(who decide on the vision, mission, \\
purposes and core objectives)* \\
• forms of expression: general methods of mental models*
\end{tabular}

Legend: * = Author's contribution.

Source: Adapted from Tavčar $(2000,2002)$, supplemented with our own findings; own expose/design. 
$1^{\text {ST }}$ INTERnational SCIENTIFIC CONFERENCE »TEACHing MethodS FOR ECONOMicS AND BUSINESS SCIENCES «

T. Štrukelj: Selected Approach to Faculty's Ethical Decision-Making towards Building a Good Student Environment

Table 2: Interdependent approaches to enterprise's ethical decision-making, part 2 Ethical analytical decision-making (according to the model, method, theory)

\section{Ethical analytical decision-making (according to the model, method, theory)}

- takes into account the circumstances

- attains high quality

- requires identification of the values of people in individual cases and in specific environments (and the identification of rules for the observance of these values or for selection among them)

- requires more knowledge, dedication and time, so often there is no time (nor capacity) for it

- concerns an area of philosophy (bases on the application of philosophical theories and knowledge of philosophical and ethical theories)

- may be very difficult: it requires in-depth and broad knowledge and skills from managers

- most appropriate for the level of strategic management*

- most commonly used by senior - top managers, i.e. principals, the DirectorsGeneral_(decision makers on strategies)*

- forms of expression: more complex methods, models, algorithms*, for example: ethics of benefits(teleological approaches), ethics of justice and rights, ethics of duties(deontological approaches), the mixed approaches, a number of other approaches

- frame-work rules of procedure for partly foreseeable conditions, capturing the routine parts of the work procedures, providing more time and capacity for the creative parts of the work procedures*

Legend: * = Author's contribution.

Source: Adapted from Tavčar $(2000,2002)$, supplemented with our own findings; own expose/design. 
T. Štrukelj: Selected Approach to Faculty’s Ethical Decision-Making towards Building a Good Student Environment

Table 3: Interdependent approaches to enterprise's ethical decision-making, part 3 Ethical routine decision-making

\section{Ethical routine decision-making}

- pre-defined choices for foreseeable conditions for (more or less mandatory instructions for treatment: what should be done in individual cases and how)

- quick and efficient

- suitable for simple situations

- rules may be inappropriate for special cases and circumstances

- best suited for the operational level of realization management and tactical level of realization management*

- most commonly used by lower - first line managers (who decide on the optimal allocation of executive tasks) and middle managers (who decide on providing and optimal allocation of resources)*

- forms of expression: a vision, mission, mission statement, fundamental objectives, regulations, rules of procedure, (moral) rules, patterns of ethical decisions for individual cases and circumstances, instructions, manuals, standards, codes, etc.*

- frame-work rules of procedure for partly foreseeable conditions, capturing the routine parts of the work procedures, providing more time and capacity for the creative parts of the work procedures*

Legend: * = Author's contribution.

Source: Adapted from Tavčar $(2000,2002)$, supplemented with our own findings; own expose/design.

\section{Ethical routine decision-making - a case of FEB}

Ethical dilemmas are dealt with in a code of ethics, which is becoming an increasingly important enterprise 'ethical tool' for routine decision-making. Code of ethics presents to an enterprise its clear orientation in the decisions that are repeated. Ethical codes are also among the essential components of the high ethical standards in business performance, because enterprises write their routine ethical business performance rules into them. Codes of ethics and similar documents (Tavčar, 2002, p. 218) are very useful as managers are relieved of the routine decision-making and guidance. Codes of ethics (Možina et al., 2004, pp. 396-397) can be important assets in many everyday decisions as they clearly and simply set out the rules of conduct. A code of ethics should be used critically and in accordance with one's own values and the values of the people who are affected by the decisions, and it should always be considered whether it corresponds to the circumstances in which one would like to use it. A code of ethics by itself does not provide adequate ethical decision-making for every circumstance, so it should be used in accordance with the actual decision and adjusted if necessary. However, one must also consider the fact that a code of ethics is a way of ensuring enterprise's ethical practices and that the enterprise ethics (Belak, Je. et al., 2010) should be planned. Codes of ethics or ethical code are becoming an increasingly important rule of enterprises' routine ethical decisionmaking; enterprises focus on their ethical routine rule sin writing. A proposal for a Code of Ethics of, for example, the Faculty of Economics and Business, University of Maribor 
$1^{\text {ST }}$ InTERnATIONAL SCIENTIFIC CONFERENCE $»$ TeACHING METHOdS FOR ECONOMICS AND BUSINESS SCIENCES «

T. Štrukelj: Selected Approach to Faculty’s Ethical Decision-Making towards Building a Good Student Environment

(FEB), is shown in Tables 4-8. The presented Code of Ethics of the Faculty of Economics and Business (FEB), University of Maribor, supports the FEB's Core Values (FEB, 2016):

- Academic freedom;

- Knowledge;

- Cooperation;

- Personal and social responsibility;

- Equality and democracy;

- Credibility and ethical action;

- Dialogue and interpersonal respect;

- Innovation;

- Critical thinking; and

- Entrepreneurship.

One of the important principles of corporate social responsibility (CSR) in ISO 26000 (ISO, 2010) is ethical behavior. It stands for the values of honesty, equity and integrity. These values imply a concern for people, animals and the environment and a commitment to address the impact of its activities and decisions on stakeholders' interests. Tables 4-8 thus show an example of possible way of implementing CSR in the FEB's organization practice - by using a code of ethics. Although we introduce the example of tertiary education code of ethics proposal, it could be used as a model of how it could look also in enterprises. When preparing a code of ethics, organizations should include their attitude towards all of their stakeholders, the animals and the natural environment.

In Tables 4-8, a proposed Code of Ethics of the Faculty of Economics and Business (FEB), University of Maribor, is one possible way to build a good teaching and learning environment so that students can acquire professional competences which will enable them to be successful in today's global business environment in an ethical and social responsible way. 
Table 4: Proposed Code of Ethics of the Faculty of Economics and Business (FEB), University of Maribor, part for the academic staff (faculty teachers and associates)

\section{Proposed Code of Ethics for FEB Academic Staff}

The academic staff, (faculty teachers and associates) of FEB strives towards high ethical standards and fully moral handling in all aspects of our work and behaviour, achieving this with dialogue and interpersonal respect. Management provides a transparent use of public money and informs all employees about important matters.

We all cooperate together and strive to continuously improve the quality of our work. From the scientific research point of view, we use academic freedom to cocreate and expand trends of social and otherwise responsible development of science and innovatively incorporate this science into our pedagogical (teaching) work and into our collaboration with organizations outside the university. We perform our teaching responsibly in accordance with all of the duties entrusted to us. We equip future graduates with the consciousness (why) and the knowledge (what and how). We educate them into intellectual elite of critical thinking of Slovenian nation, and we give them the latest economic and business skills and methodologies to stimulate their entrepreneurship. In this way, they develop into major actors of Slovenian, European and world economies. Our expertise and professionalism is deepened with the cooperation with the business sector, because, first, we have the responsibility to

transfer the latest scientific research findings into practice and, second, we are responsible for the dissemination of practical experiences in science. Whatever the scope of our appearance, we innovate and upgrade our work; we are role-models of good and honest humans who intercede on equality and democracy, and advocates of the animals and the environment. We present an upright pillar of ethics and moral behavior of Slovenian society through our personal responsibility, credibility and ethical action. 
$1^{\text {ST }}$ INTERNATIONAL SCIENTIFIC CONFERENCE »TEACHING Methods FOR ECONOMICS AND BUSINESS SCIENCES «

T. Štrukelj: Selected Approach to Faculty's Ethical Decision-Making towards Building a Good Student Environment

Table 5: Proposed Code of Ethics of the Faculty of Economics and Business (FEB), University of Maribor, part for the professional co-workers

\section{Proposed Code of Ethics for FEB professional co-workers}

Professional co-workers of FEB timely and correctly carry out our professional support for academic staff as well as students and graduates of FEB, as we co-create the goodwill of FEB in its immediate and wider environment together with them. We are aware that every service of FEB is better with excellent support services and this is why we offer the best possible quality services and constantly search for different

aspects of their possible improvements. In our professional field, we follow the innovations in order to improve our knowledge, performance in the work we have been entrusted in our society. We perform our work with full responsibility with dialogue, cooperation and interpersonal respect. We are aware that we are the ambassadors of the exchange of all and right, thus credible, information within FEB and between FEB and its environment, and in this way we co-create the success of FEB, its social responsibility and the sustainable development of the planet Earth.

Table 6: Proposed Code of Ethics of the Faculty of Economics and Business (FEB), University of Maribor, part for the students

\section{Proposed Code of Ethics for FEB students}

$\mathrm{We}$, the students of FEB, are aware that we need to acquire our knowledge in a responsible and ethical manner towards people/society, animals and the environment.

As more knowledge and experiences mean better personal preparedness for the future of our working life, in addition to regular duties as are prescribed in ours study program and study direction, we continuously look for opportunities for further education, training and practical experience in Slovenian business practice. Thus, we try to work individually and in teams to gain as much critical thinking, knowledge and experiences as possible from the study of mandatory contents, and we are also

innovating and upgrading this knowledge: we participate in lectures of visiting experts from outside FEB, and actively cooperate and participate in the organization and execution of the events, excursions and complementary educations that are organized by the FEB for us, or are otherwise available to us in an environment where we live and work. Already during the study, we transfer our knowledge, experience and information from the FEB to business practice and vice versa and thus stimulate our entrepreneurship for the future. 
T. Štrukelj: Selected Approach to Faculty's Ethical Decision-Making towards Building a Good Student Environment

Table 7: Proposed Code of Ethics of the Faculty of Economics and Business (FEB), University of Maribor, part for the graduates

\section{Proposed Code of Ethics for FEB graduates}

We, the graduates of FEB, are equally and democratically integrated into Slovenian, European and/or world economic/business practice and society, and we take care of ethical and responsible work in organizations where we work and work with, as well as ethical and responsible behaviour of the society in which we live. Therefore, we are with our operation, critical thinking and behaviour expanding ethical practice on all people and all natural/social environments where we are present, and we are personally responsible to them for the transfer of the knowledge and experiences

gained from studying at FEB. We are also obliged to continually improve and expand our expertise, spread it to others and use it responsibly. We remain loyal to FEB also after graduation, because we are aware that due to personal transformation during our study, we are FEB's lifelong stakeholders. Therefore, we will use our best opportunities for unselfish help in the development of FEB, and will actively collaborate with FEB also after graduation, in an entrepreneurial way.

Table 8: Proposed Code of Ethics of the Faculty of Economics and Business (FEB), University of Maribor, common part for the academic staff (faculty teachers and associates), professional co-workers, students and graduates

\section{Proposed Code of Ethics for all FEB staff and students}

We, the academic staff (faculty teachers and associates), professional co-workers, students and graduates of FEB, are morally obliged to create, disseminate, maintain and innovate personal and social responsibility, credibility and high ethical standards of all stakeholders of all organizations and environments in which we are active. Thus, with critical thinking, we co-create sustainable development and invest our share into the efforts for survival of the planet Earth, equality and democracy, and for the preservation of the existing society/human civilization, nature and animals. This is achieved by constantly innovating both our personal as well as institutional values, culture, ethics, norms and habits, improving the(inter)human relationships with cooperation, dialogue and interpersonal respect, upgrading our expertise, and honest realization of our profession, as well as by innovating business processes of FEB and other organizations and environments, which we can influence. We commit ourselves that we will always take full responsibility for our actions and behaviour, and the consequences that will result from it, and that we will provide with true and correct/complete information all our business partners. We are aware that only in such ethically acceptable manner, and with joint efforts, we will preserve the honour of FEB.

\section{Conclusions}

Nowadays a new, requisitely holistic way of social and economic development is needed. This requires even more creativity and innovation, including innovation in the context of enterprise policy innovation (see, e.g. Belak, Je., 2013; Dankova et al.,2015; Hauptman 
$1^{\text {ST }}$ InTERnATIONAL SCIENTIFIC CONFERENCE $»$ TeACHING METHOdS FOR ECONOMICS AND BUSINESS SCIENCES «

T. Strukelj: Selected Approach to Faculty's Ethical Decision-Making towards Building a Good Student Environment

\& Belak, Je., 2015; Štrukelj \& Šuligoj, 2014). Successful enterprises need answers to many questions, and often they have to place in the background the logic of the industry, in which they are active, and bring to the fore "endless" ways of thinking. Business ethics, which deals with criteria of business practice with regard to good and bad decisions/actions, is one of the key success factors of today business performance. The experience, reported in public press, proves that innovative enterprises succeed even in crises, because they have appropriate requisitely holistic enterprise policy and strategies, including enterprise ethics and social responsibility, exposing interdependence and holism, as important sources of productivity, efficiency, and profitability (Rejc Buhovac \& Epstein, 2014; Štrukelj, 2015). Invention-innovation-diffusion processes (IIDP) are natural consequences and components of such business practices that deserve imitation and require a transition from a traditional, self-enclosed and non-cooperative behavior of key enterprise stakeholders by the (dialectical) systems approach (Mulej et al., 2013). This approach can be - theoretically speaking - informal, e.g. supported by the ISO 26000 Standard on SR (ISO, 2010). Ethical behaviour is defined in it as human's values of honesty, equity and integrity, i.e.: concern for people, and the environment and commitment to address the impact of its activities and decisions on stakeholders' interests (ISO, 2010, pp. 10-14).

Responsible organizations (as institutions of interest-linked people and property) define their basic, general and long-term characteristics in their enterprise policy as an important management instrument influencing their development and operation. The differences in enterprises' policies result from differences in (stakeholders') interests, reflecting their values, culture, ethics, and norms (Potočan \& Mulej, 2007). The future enterprise policy, therefore governance and management, is also influenced by the existing enterprise policy (Kavčič et al., 2015; Štrukelj \& Šuligoj, 2014). To reach enterprise excellence, enterprise policy should be innovated toward social responsibility $(E U, 2011)$ through responsible and sustainable enterprise policy (Štrukelj et al., 2012) resulting from enterprises' values, culture, ethics, and norms, thus (also) from enterprise ethics, for better stakeholder quality of life. By this, enterprise culture plays an important role (Duh et al., 2016). This is why in this paper we share our professional view and experiences in the field of enterprise ethics. We present approaches to enterprise's ethical decision-making from the theory viewpoint and the importance of enterprise ethics and social responsibility promoting from both the theory and practice viewpoint. As a possible strength of a possible enterprises' practice we suggest the implementation of enterprises' code of ethic. Experiences show that this is an effective routine decision-making tool, which is worth to be incorporated into business practice.

A code of ethics is a document that expresses enterprises' social responsibility and thus leads towards better enterprises' competitiveness. Due to globalization and the increasingly harsh competitive conditions, which the owners, managers, professionals and other employees face during their enterprise development and business practice, it is important to pay more attention to the topic of business ethics as one of the enterprise's key success factors. This article thus presented our own view on basic starting-points of business ethics and focused on routine ethical decision-making: decision making with 
T. Štrukelj: Selected Approach to Faculty’s Ethical Decision-Making towards Building a Good Student Environment

pre-defined choices for the foreseeable circumstances that are similar and predictable in countries/areas/industries with similar business practices. In the contribution, we included - in our opinion - all essential and only essential viewpoints with the aim to increase knowledge about business ethics, which is useful for both for-profit and non-profit oriented enterprises/organizations.

As for an organization which educates future business people, we presented how a code of ethics can be applied in all the aspects of its operations (educational, professional and scientific activities) and implemented by all of its main stakeholders, which is of crucial importance if we are to contribute to a fair and socially responsible society and economy.

\section{References}

Ammann, M., Oesch, D., \& Schmid, M. M. (2011). Corporate governance and firm value: International evidence. Journal of Empirical Finance, 18(1), 36-55.

Belak, Je. (2013). Corporate governance and the practice of business ethics in Slovenia. Systemic Practice and Action Research, 26(6), 527-535.

Belak, Je., Duh, M., Mulej, M., \& Štrukelj, T. (2010). Requisitely holistic ethics planning as precondition for enterprise ethical behaviour. Kybernetes, 39(1), 19-36.

Belak, Je., \& Milfelner, B. (2011). Informal and formal institutional measures of business ethics implementation at different stages of enterprise life cycle. Acta Polytechnica Hungarica, $8(1), 105-122$.

Belak, Je., \& Mulej, M. (2009). Enterprise ethical climate changes over life cycle stages. Kybernetes, 38(7/8), 1377-1398.

Blanchflower, D. G., \& Oswald, A. J. (2011). International happiness: A new view on the measure of performance. Academy of Management perspective, 25(1), 6-22.

Čančer, V., \& Šarotar Žižek, S. (2015). A proposed approach to the assessment of psychological well-being in organizations. Applied Research in Quality of Life, 10(2), 217-235.

Dankova, P., Valeva, M., \& Štrukelj, T. (2015). A comparative analysis of international CSR standards as enterprise policy/governance innovation Guidelines. Systems Research and Behavioral Science, 32(2), 152-159.

Duh, M., Belak, Je., \& Milfelner, B. (2016). The importance of culture for enterprise dynamics: The role of type and strength of culture. Ekonomska istraživanja, 29(1), 263-285.

Duh, M., \& Štrukelj, T. (2011). Integration and requisite holism of enterprises' governance and management as precondition for coping with global environmental changes. Acta Polytechnica Hungarica, Journal of Applied Sciences, 8(1), 41-60.

Dyck, R. G. (2011). Whither economics? A checklist for change. Naše gospodarstvo, 57(3-4), 39.

EC (2011). Beyond GDP: Measuring progress, true wealth, and the well-being of nations. European Commission, DG Environment, DG Eurostat, and Beyond GDP Partners. Retrieved form www.beyond-gdp.eu

Epstein, M. J. (2010). Thinking straight about sustainability. Stanford Social Innovation Review, $8(3), 51-55$.

EU (2011). A renewed EU strategy 2011-14 for corporate social responsibility. Brussels: European Commission. Retrieved from http://ec.europa.eu/enterprise/policies/sustainablebusiness/files/csr/new-csr/act_en.pdf 


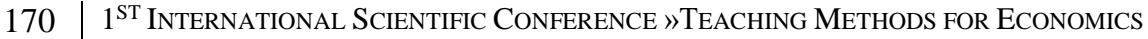
AND BUSINESS SCIENCES «

T. Strukelj: Selected Approach to Faculty's Ethical Decision-Making towards Building a Good Student Environment

FEB (2016). FEB's Core Values.University of Maribor, Faculty of Economics and Business (FEB). Retrieved December 31, 2016, from http://www.epf.um.si/en/aboutfaculty/introduction/mission-and-vision/

Hauptman, L., \& Belak, Je. (2015). Ethical tax corporate governance of state owned enterprises. Systems Research and Behavioral Science, 32(2), 183-189.

Hrast, A., Mulej, M., \& Kojc, S. (Eds.) (2013). Education and Communication for More Social Responsibility: Conference Proceedings = Izobraževanje in komuniciranje za več družbene odgovornosti: zbornik prispevkov, $8^{\text {th }}$ IRDO International Conference Social Responsibility and Current Challenges 2013 Maribor, Slovenia: IRDO.

ISO (2010). ISO 26000 - Social responsibility. Discovering ISO 26000. ISO International Organization for Standardization: International Standards for Business, Government, and Society. Retrieved from http://www.iso.org/iso/iso_catalogue/management_and_leadership_standards/social_resp onsibility/sr_discovering_iso26000.htm

Judge, T. A., \& Kammayer-Mueller, J. D. (2011). Happiness as a societal value. Academy of Management Perspective, 25(1), 30-41.

Kavčič, K., Meško, M., Meško Štok, Z., \& Markič, M. (2015). Corporate policy and the degree of management sophistication in Slovenian companies. International Journal of Management and Enterprise Development, 14(1), 70-88.

Madu, C. N., \& Kuei C. (Eds.). (2012). Handbook of sustainability management. London: Imperial College Press.

Motohashi, K., Lee, D.-R., Swang, Y.-W., \& Kim, S.-H. (2012). Innovative converged service and its adoption, use and diffusion: a holistic approach to diffusion of innovations, combing adoption-diffusion and use-diffusion paradigms. Journal of Business Economics and Management, 13(2), 308-333.

Možina, S., Tavčar, M., Zupan, N., \& Kneževič, A. N. (2004). Poslovno komuniciranje: evropske razsežnosti. Maribor: Obzorja.

Mulej, M., Božičnik, S., Čančer, V., Hrast, A., Jurše, K., Kajzer, Š., ... Ženko, Z. (2013).

Dialectical systems thinking and the law of requisite holism concerning innovation. Litchfield Park: Emergent Publications.

OECD (2011). Your Better Life Index: Country Notes. Paris, France: OECD. Retrieved from www.oecd.org/betterlifeindex

Potočan, V., \& Mulej, M. (2007). Transition into an innovativeenterprise. Maribor: University of Maribor, Faculty of Economics and Business.

Rejc Buhovac, A., \& Epstein, M. J. (2014). Making sustainability work. Best economic impacts ( $2^{\text {nd }}$ edition). Sheffield, UK: Greenleaf; San Francisco, USA: Berrett-Koehler.

Šarotar Žižek, S., Štrukelj, T., \& Mulej, M. (2011). Enterprise policy for social responsibility and enterprise stakeholder well-being. In P. Doucek, G. Chroust, \& V. Oškrdal, (Eds.), IDIMT-2011: Interdisciplinarity in Complex Systems / 19th Interdisciplinary Information Management Talks. (pp. 233-242). Linz: Trauner Verlag; Johannes Kepler Universität, Institut für Systems Engineering \& Automation: Schriftenreihe Informatik 36.

Štrukelj, T. (2015). Dialektični sistem vidikov za inoviranje upravljanja in vodenja tranzicijskega podjetja: doktorska disertacija. (Unpublished doctoral thesis), Univerza v Mariboru, Ekonomsko-poslovna fakulteta, Slovenia.

Štrukelj, T., \& Mulej, M. (2014). Promoting social responsibility and society health with care for enterprise ethics. In M. Mulej, A. Hrast, S. Kojc, (Eds.), Health - Personal and/or Social Responsibility?: Conference Proceedings $9^{\text {th }}$ IRDO International Conference Družbena odgovornost in izzivi časa 2014 (7 pages). Maribor, Slovenia: IRDO.

Štrukelj, T., Mulej, M., \& Sternad, S. (2012). Firm vision and policy innovations toward social responsibility for firm's long-term survival. In D. Tipurić, M. Dabić, (Eds.), Management, 
T. Štrukelj: Selected Approach to Faculty’s Ethical Decision-Making towards Building a Good Student Environment

governance, and entrepreneurship: new perspectives and challenges (pp. 200-216). Darwen: Access Press.

Štrukelj, T., \& Šuligoj, M. (2014). Holism and social responsibility for tourism enterprise governance. Kybernetes, 43(3-4), 394-412.

Tavčar, M. I. (2000). Kulture, etike in olika managementa. Kranj: Moderna organizacija.

Tavčar, M. I. (2002). Etika managementa. In S. Možina, R. Rozman, M. I. Tavčar, D. Pučko, Š. Ivanko, B. Lipičnik, ...B. Kovač (Eds.), Management, nova znanja za uspeh (pp. 206232). Radovljica: Didakta.

Wagner, G. (2012). But will the planet notice?: How smart economics can save the world. New York: Hill and Wang.

Wang, L., \& Juslin, H. (2012). Values and corporate social responsibility perceptions of Chinese university students. Journal of Academic Ethics, 10(1), 57-82.

Wu, J., \& Wu, T. (2010). Green GDP. In: Berkshire encyclopedia of sustainability: Vol. 2 The business of sustainability (pp. 248-259) Great Barrington: Berkshire Publishing. 


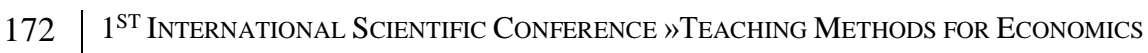
AND BUSINESS SCIENCES« 


\title{
Creative Learning through Simulated Firm
}

\author{
AMALIA VENERA TODORUȚ
}

\begin{abstract}
This paper approaches aspects regarding creative learning through simulated firm. Creative learning is based on an innovative teaching, which is regarded more as a process that involves implementing new methods, content and tools that would be benefits for students and, implicitly, for their creative potential. The paper aims at describing the student-centred teaching method called "simulated firm", like a vector for developing creative learning. This method is directed at building the competences, abilities, attitudes and personal capacity allowing students to act on behalf of being respectful of the environment and, at the same time, identifies and finds solutions for different issues in the context of sustainable development. This method supports the development of a sustainable culture relevant to their actions as responsible citizens. At the end, I present a case study referring to how to apply a simulated firm in Romania through a project.
\end{abstract}

Keywords: • creative learning • simulated firm • innovation • values • capacity building •

Correspondence Address: Amalia Venera Todoruţ, Ph.D., Professor, "Constantin Brancusi" University of Targu-Jiu, Faculty of Educational Science and Public Administrations, Victorieri street, no.15, bl.15, ap.8, Targu-Jiu, Romania, e-mail: amalia_venera@yahoo.com. 
$1^{\text {ST }}$ InTERnational SCIENTIFIC CONFERENCE »TEACHING Methods FOR ECONOMicS AND BUSINESS SCIENCES«

A. Venera Todoruț: Creative Learning through Simulated Firm

\section{$1 \quad$ Introduction}

Simulated enterprise is an interactive learning method which aims at developing entrepreneurship by integration and interdisciplinary application of knowledge that ensures conditions for practical thoroughness of the skills acquired by students in professional training. The purpose of this method is teaching the students business skills by simulating the processes and activities that occur in a real firm and its relations with other firms and institutions. The simulated enterprise facilitates learning and development of economic and legal knowledge required in a real firm, forming skills and competences that can be applied in all the economic areas and in all positions within an organization (Nicolescu, Cochină, \& Anghel, 2005).

The overall objective of learning through the simulated enterprise is developing the entrepreneurial spirit by:

Familiarizing students with the specific activities of a real firm;

$>$ Simulating the economic processes specific to the real business environment;

$>$ Improving the business language;

$>$ Providing knowledge and factual information about the action of the mechanisms of the market economy, the importance of education in achieving a career and the impact of economy on the future of young people;

$>$ Encouraging the spirit of competition, quality and responsibility;

$>$ The development of competences, skills and attitudes necessary for a dynamic entrepreneur: - creativity, competitiveness, critical thinking, analytical thinking, problem solving, decision making, accountability, teamwork, initiative, adaptability, perseverance, self-organization and self-evaluation of the individual resources and flexibility.

The implementation of the "simulated enterprise" concept aims at creating the dynamic entrepreneurial pattern, able to develop a new production process, to bring to market a new product or service or to discover a new way of distribution. The results expected from the implementation of this method are (Nicolescu et al., 2007):

$\checkmark$ Increasing the graduates' insertion on the labour market;

$\checkmark$ Reducing the period of habituation to work;

$\checkmark$ A better adaptability to changing the workplace;

$\checkmark$ Knowing the specific processes of a company;

$\checkmark$ Flexibility;

\section{Approach to set up a simulated enterprise}

In Romania, the simulated enterprises are integrated with the national network of training firms/simulated enterprises coordinated by ROCT - Centre of Network Training Firms/Simulated Enterprise from Romania (Romanian Coordination Centre of Training 
A. Venera Todoruţ: Creative Learning through Simulated Firm

Firms) (www.roct.ro). ROCT is a department of the National Centre for the Development of Vocational and Technical Education and has the following responsibilities:

$\checkmark$ It registers training firms/simulated enterprises in high schools and higher education from Romania, according to the procedures of registration of a real firm.

$\checkmark$ It coordinates the activity of the national network of training firms/simulated enterprises in Romania through:

$\checkmark$ The simulation of the activities developed by the Chamber of Commerce and Industry of Romania and the Trade Register;

$\checkmark$ The simulation of the activities of the virtual bank national and international settlement activities;

$\checkmark$ The simulation of the activities referring to social and health insurance payments, taxes and fees, as required by law;

$\checkmark$ Organizing activities for training teachers on training firms/simulated enterprises;

$\checkmark$ Organizing and participating in manifestations and international projects related to the activity of training firms/simulated enterprises;

$\checkmark$ Developing partnerships with economic agents;

$\checkmark$ Elaborating teaching materials for training firms/simulated enterprises;

$\checkmark$ Disseminating information on partnership opportunities on the international market of training firms/simulated enterprises, in the country and abroad;

$\checkmark$ It represents training firms/simulated enterprises from the international network EUROPEN;

$\checkmark$ It monitors and assesses the activity of the training firms/simulated enterprises in the national network.

ROCT ensures all the activities that simulate the external environment of a real enterprise. ROCT represents a unique structure at a national level, being affiliated to EUROPEN ("EUROpean Practice Enterprises Network") starting with the school/academic year 2008/2009 - The international network of training firms/simulated enterprises.

Students go through a series of steps in establishing a simulated firm as follows (www.roct.ro):

1. Reserving the name of the simulated enterprise;

2. Registering the simulated enterprise on the ROCT platform;

3. Filling the necessary documents to validate the simulated enterprise. For the new enterprise to become active both on the roct.ro platform and in the Simulated enterprise program, it is necessary to fill in the documents below:

a) Application for reserving the name;

b) Registration form in the SE database;

c) The Constitutive Act of the SE;

d) Application for the SE tax record; 

AND BUSINESS SCIENCES «

A. Venera Todoruț: Creative Learning through Simulated Firm

e) Authorisation request for the SE activity;

f) Rental Agreement for the SE;

g) Statement on authorising the SE activity;

h) SE Statement;

i) Account opening form for the SE;

j) Signature specimen for the SE;

4. The validation of the simulated enterprise and receiving the official documents. Based on the documents sent by the simulated enterprise, ROCT issues the documents to be submitted to it. From now on, the simulated enterprise starts to work with the other simulated enterprises, being able to make virtual transactions and take part in the national and international fairs held in Romania or other countries.

Documents issued by ROCT are: Certificate of registration (enforceable document against third parties); Explanations symbolization: Certificate of registration; Ascertaining Certificate; Receipt for the name reservation fee; Receipt for formation expenses; Fiscal record.

\section{The steps of the simulated enterprises activities}

The main steps of developing activities within the simulated enterprises refer to (Nicolescu et al. 2007):

Step 1: Setting up the simulated enterprise:

Establishing the new firm coordinates by specifying:
a. the object of activity,
b. name,
c. legal form,
d. social capital,

Designation of the general manager;

$>$ Filling in the constitutive documents according to the ROCT requests (www.roct.ro): reserving the name of the simulated enterprises; registering the simulated enterprise on the roct.ro platform;

Filling in the necessary documents to validate the simulated enterprise; 
A. Venera Todoruț: Creative Learning through Simulated Firm

Step 2: Simulating the employment procedure for jobs of the simulated enterprise by filling in the following documents:

> CV; Letter of intent; Recommendation; Employment Application; Interview Guide; Employment file (Copy of the identity documents of employee: card/ID card, job application, CV, Letter of Intent, Recommendation, Employment decision, the minutes of the interview committee, individual employment contract, Medical Certificate, job description); Instruction sheet at employment regarding health and safety at work.

Step 3: The job description is learnt by employees.

Step 4: The progress of the relations between the simulated enterprise and ROCT takes into consideration as priority:

regular consultation of the site www.roct.ro; the notification of ROCT Centre regarding any legal changes occurred within the simulated enterprise; the monthly transmission of archived payment instruments to ROCT, on banca.virtuala@roct.ro address; the achievement of, at least, one national economic transaction per month; contacting at least three simulated enterprises from abroad during an academic year and achieving international economic transactions with them; the compliance of registration procedures in national and international fairs according to ROCT.

Step 5: The commercial transactions progress with internal and external partners, in accordance with ROCT approach.

Step 6: Elaborate and submit the file with the documentation regarding the simulation progress.

\subsection{Case study - aspects of the activity within the simulated enterprise in Romania}

The project "Transition from school to working life through practice and simulated enterprise" had an important role in implementing the concept of simulated enterprise in Romania. So, through this project the following has been pursued:

$\checkmark$ To facilitate and improve the access on the labour market for 7000 students, by providing advice and guidance through: counselling meetings and individual and group professional orientation, organized in universities, within some workshops and the Summer School; counselling and professional orientation in cyberspace - using ICT and Smartphone application;

$\checkmark$ To support the development of entrepreneurial and innovative spirit among a minimum of 2250 students by organizing and implementing activities as a simulated enterprise. 

AND BUSINESS SCIENCES «

A. Venera Todoruț: Creative Learning through Simulated Firm

$\checkmark$ To improve the insertion of students on the labour market through internships in real firms for 500 students.

The main expected results are:

- 7000 students participating in direct counselling and professional orientation;

- 200 students participating in counselling and professional orientation activities within the Summer School;

- 3000 students that will use developed online and Smartphone instruments within the project;

- 7 territorial centres within the partner arranged universities where the simulated enterprises will develop their activity;

- 25 simulated enterprises set up according to ROCT methodology - Centre of Network Training Firms/Simulated Enterprise from Romania;

- 2250 students involved in internships within the simulated enterprises;

- 3 national fairs of the organised simulated enterprises;

- 25 simulated enterprises participating in fairs;

- at least 900 members of the target group taking part in fairs;

- 9 simulated enterprises awarded;

- 9 enterprises participating European fairs of the simulated enterprises;

- At least 25 framework conventions concluded with firms that will develop internships;

- 500 students participating in internships within real enterprises;

- 1 set of batteries of psychological and vocational test for SUDENTS - in order to achieve the matching with professions that are appropriate to their profile and available on the project's site;

- 1 Smartphone application.

It is thought that the proposal regarding the integration of some managerial methods and software instruments had an important role:

The assessment of students involved in simulated enterprises based on an activity report made at the end of a three-month cycle. In this regard, we propose that the performances evaluation of the simulated enterprises be based on the Balanced Scorecard method, so that the achieved performances are analyzed from multiple perspectives (financial, customers, internal processes and organizational learning). Students will receive the task at the beginning of a simulation cycle to develop systems of performance key indicators that integrate all the activities which will take place within the simulated enterprises;

$>$ The creation of an online platform for networking and dissemination of the results achieved by all the simulated enterprises managed by partners; in this way, a good collaboration between students from all universities and also, the transparency of the results and performances registered by the virtual enterprises created through this project will be ensured. 
$>$ The use within the simulated firm activities of some Project Management software solutions. Thus, the simulated enterprises' managers will also benefit from these software tools, which are materialized in planning activities, the inventory of resources and their allocation to the developed activities, highlighting the cost on activities/resources etc.

$>$ Identifying opportunities for students to take part in simulated enterprises' competitions, in addition to those promoted in EUROPEN network, such as Virtual Business Challenges managed by Junior Achievement-Young Enterprise Europe (http://www.jaeurope.org/).

At the level of the "Constantin Brâncuşi" University from Targu-Jiu, three simulated enterprises, "Best Consulting SE", "Smart Thinking" and "Gorj Lex", were established, which involved a target group of 600 students. They took part in three editions of the simulated enterprises Fairs and were awarded for the most innovative products, the best seller and the best offer.

\section{Conclusions}

'The simulated enterprise' is an interplay learning method, a modern concept for an interdisciplinary integration and application of knowledge, an approach of teachinglearning process ensuring proper conditions for probing and practical thorough learning of the abilities achieved by students in the course of professional training.

Via this innovating method, besides the economic practical activities found in the real firms, the students may simulate a series of processes and activities directed towards education for sustainability. The simulated enterprise is a model of real enterprise, being a method of practical approaching with integrated contents, a method conceived to form personal attitudes and behaviours which, starting with the basic functions to those of management within an enterprise, may be applied in all the economic domains. Through this method, the students may be involved as agents of change in the challenges connected with sustainability by simulating activities and initiating business which then, can favour creating a whole culture for sustainability.

The acquired key skills (i.e. the ability to work in team, interdisciplinary thinking, communication abilities and decision-making capacity) allow students to achieve some professional skills and a high flexibility in the labour market and also, finding affinity for a particular job. The achieved skills can easily determine finding a new job, while reducing the period of getting used to work, which is especially beneficial for both future employees and the employer.

The simulated enterprise is, therefore, an exceptional training for a successful integration of students in the professional life, as it requires creativity, innovation, risk taking and the ability to plan and manage projects, too, in order to achieve the objectives. 
$1^{\text {ST }}$ InTERnational SCIENTIFIC CONFERENCE »TEACHING METHOdS For ECONOMics AND BUSINESS SCIENCES «

A. Venera Todoruț: Creative Learning through Simulated Firm

\section{References}

Nicolescu, O., \& Verboncu, I., (2007) Managementul organizaţiei. Bucureşti: Editura Economică.

Nicolescu, O., Cochină, I., \& Anghel F. (2005). Simularea managerial-intreprenorială-PRELEM $X X I-2003$. București: Editura Olimp.

Nicolescu O., Popa I., Nicolescu C., Anghel F., Ceptureanu S., \& Ceptureanu E. (2007). Aplicații și scheme pentru training și consultanță în managementul pragmatic al firmelor, managementul resurselor umane și în managementul proiectelor cu finanțare națională și international. București: Editura Olimp.

Nicolescu, O., \& Radu. I. (1995). SIMACO - Cartea jucătorului. Bucureşti: Editura Economică.

ROCT - Centrala Rețelei Firmelor de Exercițiu / Întreprinderilor Simulate din România. (2017). Metodologie. Retrieved from https://www.roct.ro 


\title{
The Quest for Optimal Fusion of Learning, Teaching and Evaluation for Improving Student Classroom
}

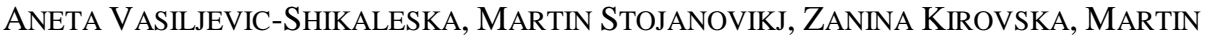 \\ KISELICKI \& BILJANA GJOZINSKA
}

\begin{abstract}
This paper presents a comprehensive investigation of the preferred learning styles of students and the manner materials are being presented in the classroom, as one of the most important components in the learning environment. Therefore, a survey of students' and teachers' views on the use of various learning and teaching techniques during classes was conducted. Data were summarized using descriptive statistical analysis. Students' opinion is that extensive use of exercises with real business data and case studies is very important and would contribute the most to their acquired knowledge. Teachers' perspective differs only in the employment of problem based learning which they also consider as very beneficial teaching method. The shift of lectures from professor-to-student to student-to-student interaction greatly fosters the active and collaborative instead of cooperative learning style. The introduction of open-book and oral examination would additionally enable more accurate evaluation of students' knowledge. Taken together, matching the learning and teaching styles combined with accurate knowledge evaluation would improve overall students' academic achievement.
\end{abstract}

KEYWORDS: - learning style - teaching style • active learning • collaborative learning $\bullet$ business and management $\bullet$

CoRReSPONDENCE AdDRESSEs: Aneta Vasiljevic-Shikaleska, Ph.D., Assistant Professor, Integrated Business Institute, Str. "3-ta Makedonska Brigada" no. 66A - Floor 1, 1000 Skopje, Macedonia, email: aneta@fbe.edu.mk. Martin Stojanovikj, M.Sc., Lecturer, Integrated Business Faculty, Str. "3ta Makedonska Brigada" no. 66A - Floor 1, 1000 Skopje, Macedonia, e-mail: martin.stojanovik@fbe.edu.mk. Zanina Kirovska, Ph.D., Associate Professor, Integrated Business Institute, Str. "3-ta Makedonska Brigada" no. 66A - Floor 1, 1000 Skopje, e-mail: zanina.kirovska@fbe.edu.mk. Martin Kiselicki, M.Sc., Lecturer, Integrated Business Faculty, Str. "3-ta Makedonska Brigada" no. 66A - Floor 1, 1000 Skopje, e-mail: martin.kiselicki@ fbe.edu.mk. Biljana Gjozinska, Ph.D., Assistant Professor, Integrated Business Institute, Str. "3-ta Makedonska Brigada" no. 66A - Floor 1, 1000 Skopje, e-mail: biljana.gjozinska@ fbe.edu.mk. 
$1^{\text {ST }}$ INTERNATIONAL SCIENTIFIC CONFERENCE »TEACHING METHOdS FOR ECONOMICS AND BUSINESS SCIENCES «

A. Vasiljevic-Shikaleska, M.Stojanovikj, Z. Kirovska, M. Kiselicki \& B. Gjozinska: The Quest for Optimal Fusion of Learning, Teaching and Evaluation for Improving Student Classroom

\section{Introduction}

The review of relevant literature strongly indicates that understanding of learning styles and the role of learning styles in the teaching and learning process is one of the key components for improving students' classroom experience and preparing the students for careers in the competitive and demanding business world. It was shown that academic performances of students are greatly affected by their learning styles (Garton et al., 1999, pp. 11-20) and that knowledge of learning styles and a commitment to match them with teaching styles and strategies are one of the main factors for a successful teaching process (Rogowsky et al., 2015, pp. 64-78). In the process of learning and the interaction with the learning environment students obtain a lot of new information which is later on associated to the preliminary information already existing in their memories thus causing changes in both, the existing and new information. It was observed that greater learning gains can be achieved when teaching is designed by having in mind students' learning styles (Larkin, 2003, pp. 1-8).

Up-to-date, very extensive work has been carried out on investigating the learning and teaching styles and valuable result were obtained. According to (Cassidy, 2004, pp. 419444) and (Tulbure, 2012, pp. 65-74) the learning style is a habitual process of perceiving and thinking. It is intimately related with personality, affection, and motivation characteristics and can serve as an indicator to predict students' success in classroom activities. Furthermore, (Sternberg et al., 2008, pp. 486-506) divided the learning and thinking into two basic styles: ability based and personality based, and said that both are important for teaching and assessment. It was stated that teachers need to account differences in how students learn and think and design instruction accordingly to obtain optimal instructional outcomes. Researchers elaborated that teachers believe that students perform better when they receive information in their preferred learning style and that students with strong learning style preference can benefit more in academic outcome (Dekker et al., 2012, pp. 1-8; Altun \& Yazici, 2010, pp. 98-202).

Generally, learning styles are styles or individual learning technique that act with its environment, to process, interpret and obtain information, experiences or desirable skills (Othaman \& Amiruddin, 2010, pp. 652-660).

Teaching styles on the other hand, can be defined as teaching roles comprising attitudes, behaviors, preferred methods and techniques (Vaughn \& Baker, 2001, pp. 610-612; Visser et al., 2006, pp. 97-112).

Based on the teacher's thoughts, ability, and beliefs about what constitutes a good teaching the teaching styles can vary between a teacher-centered and a student-centered teaching style (Alhussain, 2012, pp. 122-129). Some teachers believe that a class should be teacher-centered, where the teacher is the expert and authority in presenting information. Contrary, others take a learner-centered approach, where teachers view their role more like a facilitator for students learning. 
A. Vasiljevic-Shikaleska, M.Stojanovikj, Z. Kirovska, M. Kiselicki \& B. Gjozinska: The Quest for Optimal Fusion of Learning, Teaching and Evaluation for Improving Student

Teaching style awareness may also affect classroom setting, activities assessment, and teacher-student interactions which become information for better understanding, changing, modifying, and supporting to improve their interaction with students while maintaining all contextual aspects of teaching. Additionally, it was observed that student diversity is a factor which also needs to be taken into consideration by teachers (Bidabadi \& Yamat, 2010, pp. 219-226). Teachers should be aware that before planning their teaching process and assessment in classrooms, they should consider also this diversity factor and create the most appropriate ambience with students' academic achievement and their needs, so that various learning experience structure are assignable to all students. This includes diverse learning styles such as visual, auditory, aural or kinaesthetic. Having in mind that students do not learn the same way, it is very important for the teachers to understand learning style differences and teach in a manner in which all learning styles are incorporated. It would enable the largest number of students can to learn equally and effectively (Cano et al., 1992, pp. 8-15).

Assessment is another vital part of the teaching and learning process. It is very important for the teacher to ensure that there is alignment between teaching methods, learning outcomes and assessment criteria since this correlation enables to make the overall learning experience more transparent and meaningful for students.

There are various assessment methods used in higher education to assess students' achievements. Primarily, by the assessment method chosen, the teacher needs to be able to effectively assess the objectives and learning outcomes of the course, module or the overall aims of the study programme. Therefore, when choosing assessment items, the teacher should on one hand consider the immediate task of assessing student learning in a particular unit of study, and on the other hand has to bear in mind the broader aims of the programme and the competences and the graduate profile.

Out of what teachers do, nothing affects students more than assessment. Poor assessment methods can distort the picture of students' knowledge and their achievements in the learning process. Good assessment practice includes feedback activities that accompany the process of teaching and learning. Assessment comprises of designing assignments and exams, grading and giving feedback on students' performance.

In general, assessment can be summative or formative. Summative is usually measured at the end of a course or module or a period of learning. The outcome of summative assessment is normally a final grade or mark of the overall performance in the course with almost no feedback. Formative assessment is done during a course or any other form of learning/teaching. Even though students are graded at the end of the course, they receive timely feedback on segments of the subject matter taught, which helps them detect their strengths or weaknesses during the course in order to either repair or strengthen them (Fry et al., 2009, pp. 137). 
$1^{\text {ST }}$ InTERnational SCIENTIFic CONFERENCE »TEACHING METHOdS FOR ECONOMics AND BUSINESS SCIENCES «

A. Vasiljevic-Shikaleska, M.Stojanovikj, Z. Kirovska, M. Kiselicki \& B. Gjozinska:

The Quest for Optimal Fusion of Learning, Teaching and Evaluation for Improving

Student Classroom

It is more than obvious that students' development and academic achievement are very closely related with the learning, teaching and assessment methods being implemented at the respective educational institution. Therefore, the aim of this paper was to find the optimal combination between learning and teaching style along with accurate knowledge evaluation thus ensuring greater academic success of students. Several teaching methods and techniques inside and outside of the lecture format were analyzed, from two points of view (students and teachers), in terms of their importance and utilization on the business and management courses at the Integrated Business Faculty in Skopje (R. Macedonia). Utilization of different assessment methods was also assessed. The following table provides a descriptive presentation of the teaching methods and techniques subject to this study. 
A. Vasiljevic-Shikaleska, M.Stojanovikj, Z. Kirovska, M. Kiselicki \& B. Gjozinska: The

Quest for Optimal Fusion of Learning, Teaching and Evaluation for Improving Student

Classroom

Table 1: Brief description of the teaching methods and techniques analyzed in the paper

\begin{tabular}{|c|c|}
\hline $\begin{array}{c}\text { Teaching } \\
\text { method/technique }\end{array}$ & Description \\
\hline Seminar & $\begin{array}{l}\text { A meeting between the teacher and a very small group of } \\
\text { students to discuss a particular topic. It is often based on } \\
\text { feedback to an essay or assignment. During the discussion } \\
\text { a paper is being presented by a student or students and } \\
\text { under tutorials (Fry et al., 2009, p. 79). }\end{array}$ \\
\hline Tutorial & $\begin{array}{l}\text { A small group of students in which they discuss about } \\
\text { their work with the teacher }\end{array}$ \\
\hline Exercise classes & Practical exercises relevant to the course \\
\hline Workshop & $\begin{array}{l}\text { A class or series of classes in which a small group of } \\
\text { students exchange of ideas and learn/ practice the methods } \\
\text { and skills used for doing something. }\end{array}$ \\
\hline Case study & $\begin{array}{l}\text { A documented study of a specific real-life situation or } \\
\text { imagined scenario. Students have to analyse the } \\
\text { prescribed cases and present their interpretations or } \\
\text { solutions, supported by the line of reasoning employed } \\
\text { and assumptions made }\end{array}$ \\
\hline $\begin{array}{l}\text { Problem based learning } \\
\text { (PBL) }\end{array}$ & $\begin{array}{l}\text { Students gain knowledge and skills by working for an } \\
\text { extended period of time to investigate and respond to a } \\
\text { complex question, problem, or challenge }\end{array}$ \\
\hline Online/Distance learning & $\begin{array}{l}\text { Learning process, which includes learning with the } \\
\text { assistance of the Internet and a personal computer }\end{array}$ \\
\hline Buzz-groups & $\begin{array}{l}\text { Small groups of } 2-3 \text { participants which discuss a specific } \\
\text { question or issue in order to come up with many ideas in } \\
\text { a short time. }\end{array}$ \\
\hline Snowballing & Turning buzz groups into larger groups. \\
\hline Cross-overs & Mixing students into groups \\
\hline Rounds & Giving turns to individual students to talk \\
\hline Role play & $\begin{array}{l}\text { A simulation exercise where teacher and students take on } \\
\text { assumed roles in order to act out a scenario in a } \\
\text { contrived setting. The participants can act out the } \\
\text { assigned roles in order to explore the scenario, apply } \\
\text { skills, experience the scenario from another view point, } \\
\text { evoke and understand emotions that maybe alien to } \\
\text { them. It helps to make sense of theory and gathers } \\
\text { together the concepts into a practical experience. }\end{array}$ \\
\hline
\end{tabular}


$1^{\text {ST }}$ InTERNATIONAL SCIENTIFIC CONFERENCE »TEACHING METHOdS FOR ECONOMICS AND BUSINESS SCIENCES «

A. Vasiljevic-Shikaleska, M.Stojanovikj, Z. Kirovska, M. Kiselicki \& B. Gjozinska:

The Quest for Optimal Fusion of Learning, Teaching and Evaluation for Improving

Student Classroom

\section{$2 \quad$ Data and methodology}

Data were gathered from a sample consisting of first, second and third year undergraduate students studying business and management at the Integrated Business Faculty in Skopje, R. Macedonia and the teachers involved in the respective courses. The sample consisted of 117 respondents, 108 of which were student, and the remaining were professors.

The investigation was conducted using a survey method with previously prepared questionnaires in order to gather information about:

a. The learning styles students usually practice in the business and management courses

b. The teaching styles and assessment methods usually applied by the respective professors

c. The opinions of both, students and teaching staff, about such styles and methods.

Therefore, two types of questionnaires, consisting of questions with multiple-choice answers and questions with a Likert scale, were developed and administered to the students and teachers as well.

Once the surveying process was completed data were processed and analyzed using descriptive statistics in terms of frequency, percentage, mean and standard deviation (Rogowsky et al., 2015, pp. 64-78; Dincol et al., 2011, pp. 854-858).

\section{$3 \quad$ Main findings}

The study aimed to investigate and fuse together the learning and teaching methods utilized on the business and management courses at the Integrated Business Faculty in order ensure classroom effectiveness and enable greater academic success of students. Several teaching methods and techniques, in terms of their importance and utilization on the business and management courses were studied. Consequently, the results are as follows:

\subsection{Frequency of utilizing particular teaching methods during the classes of business and management and importance of such methods}

The results show that most of the students agree that practical exercises $(26 \%)$ were very often used at the classes of business and management whereas both, the seminars $(31 \%)$ and tutorials (25\%) were frequently delivered (Table 2 ). In response to the question about the importance of each of these methods students answers were that practical exercises $(46 \%)$, seminars $(37 \%)$ and problem based learning $(31 \%)$ would contribute at most towards achieving specific knowledge and skills (Table 3). 
A. Vasiljevic-Shikaleska, M.Stojanovikj, Z. Kirovska, M. Kiselicki \& B. Gjozinska: The

Quest for Optimal Fusion of Learning, Teaching and Evaluation for Improving Student

Classroom

Table 2: Students' opinion about the frequency of usage of particular teaching method

\begin{tabular}{|l|c|c|c|c|c||}
\hline $\begin{array}{c}\text { Type of } \\
\text { activity }\end{array}$ & $\begin{array}{c}1 \text { (Very } \\
\text { often) }\end{array}$ & $\begin{array}{c}\mathbf{2} \\
\text { (Frequently) }\end{array}$ & $\begin{array}{c}\mathbf{3} \\
\text { (Neutral) }\end{array}$ & $\begin{array}{c}\mathbf{4} \\
\text { (Rarely) }\end{array}$ & $\begin{array}{c}\mathbf{5} \\
\text { (Never) }\end{array}$ \\
\hline Seminar & $26 \%$ & $31 \%$ & $19 \%$ & $10 \%$ & $13 \%$ \\
\hline Tutorials & $16 \%$ & $25 \%$ & $21 \%$ & $19 \%$ & $19 \%$ \\
\hline Exercise & $26 \%$ & $21 \%$ & $30 \%$ & $10 \%$ & $13 \%$ \\
\hline Workshops & $15 \%$ & $19 \%$ & $28 \%$ & $22 \%$ & $16 \%$ \\
\hline Case study & $18 \%$ & $19 \%$ & $20 \%$ & $21 \%$ & $21 \%$ \\
\hline PBL & $17 \%$ & $22 \%$ & $28 \%$ & $18 \%$ & $16 \%$ \\
\hline $\begin{array}{l}\text { Distance } \\
\text { learning }\end{array}$ & $19 \%$ & $19 \%$ & $19 \%$ & $17 \%$ & $25 \%$ \\
\hline
\end{tabular}

Table 3: Students' opinion about the importance of the particular method for achieving specific knowledge and skills

\begin{tabular}{||l|c|c|c|c|c||}
\hline $\begin{array}{c}\text { Type of } \\
\text { activity }\end{array}$ & $\begin{array}{c}\mathbf{1} \text { (Very } \\
\text { important) }\end{array}$ & $\begin{array}{c}\mathbf{2} \\
\text { (Important) }\end{array}$ & $\begin{array}{c}\mathbf{3} \\
\text { (Neutral) }\end{array}$ & $\begin{array}{c}\mathbf{4} \text { (Not } \\
\text { important) }\end{array}$ & $\begin{array}{c}\mathbf{5} \text { (Not } \\
\text { important } \\
\text { at all) }\end{array}$ \\
\hline Seminar & $37 \%$ & $25 \%$ & $17 \%$ & $9 \%$ & $12 \%$ \\
\hline Tutorials & $27 \%$ & $29 \%$ & $22 \%$ & $14 \%$ & $8 \%$ \\
\hline Exercise & $46 \%$ & $19 \%$ & $14 \%$ & $13 \%$ & $8 \%$ \\
\hline Workshops & $25 \%$ & $27 \%$ & $19 \%$ & $19 \%$ & $10 \%$ \\
\hline Case study & $27 \%$ & $25 \%$ & $23 \%$ & $14 \%$ & $11 \%$ \\
\hline PBL & $31 \%$ & $28 \%$ & $18 \%$ & $13 \%$ & $10 \%$ \\
\hline $\begin{array}{l}\text { Distance } \\
\text { learning }\end{array}$ & $19 \%$ & $21 \%$ & $29 \%$ & $17 \%$ & $14 \%$ \\
\hline
\end{tabular}

Previous results are aligned with the descriptive statistics of means and standard deviations (SD) summarized in Table 4. It can be seen that the most important and most frequently used teaching method according the mean value is the "practical exercises" method with a mean value of 2.19 and 2.63, respectively. Herein we would like to emphasize that lower mean value indicates greater frequency of utilization and higher importance of the respective teaching method. The standard deviation for the "practical exercises" method for both cases, importance of the method and frequency of its usage, is almost the same (1.36 and 1.32). The next methods, according the mean value of the method importance and frequency of its usage are the seminars (2.34 and 2.53) and problem based learning (2.43 and 2.94). 
$1^{\text {ST }}$ INTERNATIONAL SCIENTIFIC CONFERENCE »TEACHING METHODS FOR ECONOMICS AND BUSINESS SCIENCES «

A. Vasiljevic-Shikaleska, M.Stojanovikj, Z. Kirovska, M. Kiselicki \& B. Gjozinska: The Quest for Optimal Fusion of Learning, Teaching and Evaluation for Improving Student Classroom

Table 4: Summary statistics for the frequency of usage and importance of particular teaching method (students' opinion)

\begin{tabular}{||l|c|c|c|c||}
\hline \multirow{2}{*}{ Type of activity } & \multicolumn{2}{|c|}{ Frequency of usage } & \multicolumn{2}{c||}{ Importance } \\
\cline { 2 - 5 } & Mean & SD & Mean & SD \\
\hline Seminar & 2.53 & 1.32 & 2.34 & 1.37 \\
\hline Tutorial & 3.00 & 1.35 & 2.48 & 1.25 \\
\hline Exercises & 2.63 & 1.32 & 2.19 & 1.36 \\
\hline Workshop & 3.05 & 1.28 & 2.62 & 1.34 \\
\hline Case study & 3.09 & 1.40 & 2.57 & 1.31 \\
\hline Problem based learning & 2.94 & 1.30 & 2.43 & 1.32 \\
\hline Online learning & 3.08 & 1.46 & 2.84 & 1.30 \\
\hline
\end{tabular}

Teachers' perspective concerning the frequency of using the mentioned teaching techniques during the classes and their importance is similar to the students opinion and differs only in the employment of problem based learning and workshops. Teachers deem these methods also as very beneficial and highly important. These data, as presented in Tables 5 and 6 , show that workshops and problem based learning were used frequently, comprising 56\% and $44 \%$ of the answers given. The calculated low values of means 1.11 for both, workshops and problem based learning (Table 7), indicate that teachers consider these methods as highly important for achieving specific knowledge and skills.

Table 5: Teachers' opinion about the frequency of utilizing particular teaching method

\begin{tabular}{|l|c|c|c|c|c||}
\hline $\begin{array}{c}\text { Type of } \\
\text { activity }\end{array}$ & $\begin{array}{c}\mathbf{1} \text { (Very } \\
\text { often) }\end{array}$ & $\begin{array}{c}\mathbf{2} \\
\text { (Frequently) }\end{array}$ & $\begin{array}{c}\mathbf{3} \\
\text { (Neutral) }\end{array}$ & $\begin{array}{c}\mathbf{4} \\
\text { (Rarely) }\end{array}$ & $\begin{array}{c}\mathbf{5} \\
\text { (Never) }\end{array}$ \\
\hline Seminar & $56 \%$ & $33 \%$ & $0 \%$ & $11 \%$ & $0 \%$ \\
\hline Tutorials & $0 \%$ & $22 \%$ & $33 \%$ & $44 \%$ & $0 \%$ \\
\hline Exercise & $44 \%$ & $44 \%$ & $11 \%$ & $0 \%$ & $0 \%$ \\
\hline Workshops & $11 \%$ & $56 \%$ & $33 \%$ & $0 \%$ & $0 \%$ \\
\hline Case study & $0 \%$ & $33 \%$ & $22 \%$ & $44 \%$ & $0 \%$ \\
\hline PBL & $22 \%$ & $44 \%$ & $33 \%$ & $0 \%$ & $0 \%$ \\
\hline $\begin{array}{l}\text { Distance } \\
\text { learning }\end{array}$ & $0 \%$ & $11 \%$ & $0 \%$ & $33 \%$ & $56 \%$ \\
\hline \hline
\end{tabular}


A. Vasiljevic-Shikaleska, M.Stojanovikj, Z. Kirovska, M. Kiselicki \& B. Gjozinska: The Quest for Optimal Fusion of Learning, Teaching and Evaluation for Improving Student Classroom

Table 6: Teachers' opinion about the importance of the respective method for achieving specific knowledge and skills

\begin{tabular}{|l|c|c|c|c|c||}
\hline $\begin{array}{c}\text { Type of } \\
\text { activity }\end{array}$ & $\begin{array}{c}\mathbf{1} \text { (Very } \\
\text { important) }\end{array}$ & $\begin{array}{c}\mathbf{2} \\
\text { (Important) }\end{array}$ & $\begin{array}{c}\mathbf{3} \\
\text { (Neutral) }\end{array}$ & $\begin{array}{c}\mathbf{4} \text { (Not } \\
\text { important) }\end{array}$ & $\begin{array}{c}\mathbf{5} \text { (Not } \\
\text { important } \\
\text { at all) }\end{array}$ \\
\hline Seminar & $44 \%$ & $56 \%$ & $0 \%$ & $0 \%$ & $0 \%$ \\
\hline Tutorials & $0 \%$ & $89 \%$ & $11 \%$ & $0 \%$ & $0 \%$ \\
\hline Exercise & $89 \%$ & $11 \%$ & $0 \%$ & $0 \%$ & $0 \%$ \\
\hline Workshops & $56 \%$ & $44 \%$ & $0 \%$ & $0 \%$ & $0 \%$ \\
\hline Case study & $22 \%$ & $56 \%$ & $11 \%$ & $11 \%$ & $0 \%$ \\
\hline PBL & $89 \%$ & $11 \%$ & $0 \%$ & $0 \%$ & $0 \%$ \\
\hline $\begin{array}{l}\text { Distance } \\
\text { learning }\end{array}$ & $0 \%$ & $11 \%$ & $11 \%$ & $56 \%$ & $22 \%$ \\
\hline
\end{tabular}

Table 7: Summary statistics for the frequency of usage and importance of particular teaching method (teachers' opinion)

\begin{tabular}{||l|c|c|c|c||}
\hline & \multicolumn{2}{|c|}{ Frequency of usage } & \multicolumn{2}{c||}{ Importance } \\
\hline & Mean & SD & Mean & SD \\
\hline Seminar & 1.67 & 0.94 & 1.56 & 0.5 \\
\hline Tutorial & 3.22 & 0.79 & 2.11 & 0.31 \\
\hline Exercises & 1.67 & 0.67 & 1.11 & 0.31 \\
\hline Workshop & 2.22 & 0.63 & 1.44 & 0.50 \\
\hline Case study & 3.11 & 0.87 & 2.11 & 0.87 \\
\hline Problem based learning & 2.11 & 0.74 & 1.11 & 0.31 \\
\hline Online learning & 4.33 & 0.94 & 3.89 & 0.87 \\
\hline \hline
\end{tabular}

\subsection{Types of teaching techniques utilized inside and outside the lecture \\ format}

When asked about the teaching techniques used inside the lecture format teachers said that inside the lecture format they utilize almost equally student's presentations, crossovers and role play with exception of the rounds which are used with 7 to10 percentage points above the other inside the lecture techniques. However, the answers given by the students imply that students would prefer student's presentations and buzzgroups (Figure 1) which on the other hand enables shifting even more the teaching approach towards student-to student interaction. 
$1^{\text {ST }}$ INTERnational SCIENTIFic CONFERENCE $\gg$ TEACHING METHOdS FOR ECONOMICS AND BUSINESS SCIENCES «

A. Vasiljevic-Shikaleska, M.Stojanovikj, Z. Kirovska, M. Kiselicki \& B. Gjozinska: The Quest for Optimal Fusion of Learning, Teaching and Evaluation for Improving Student Classroom

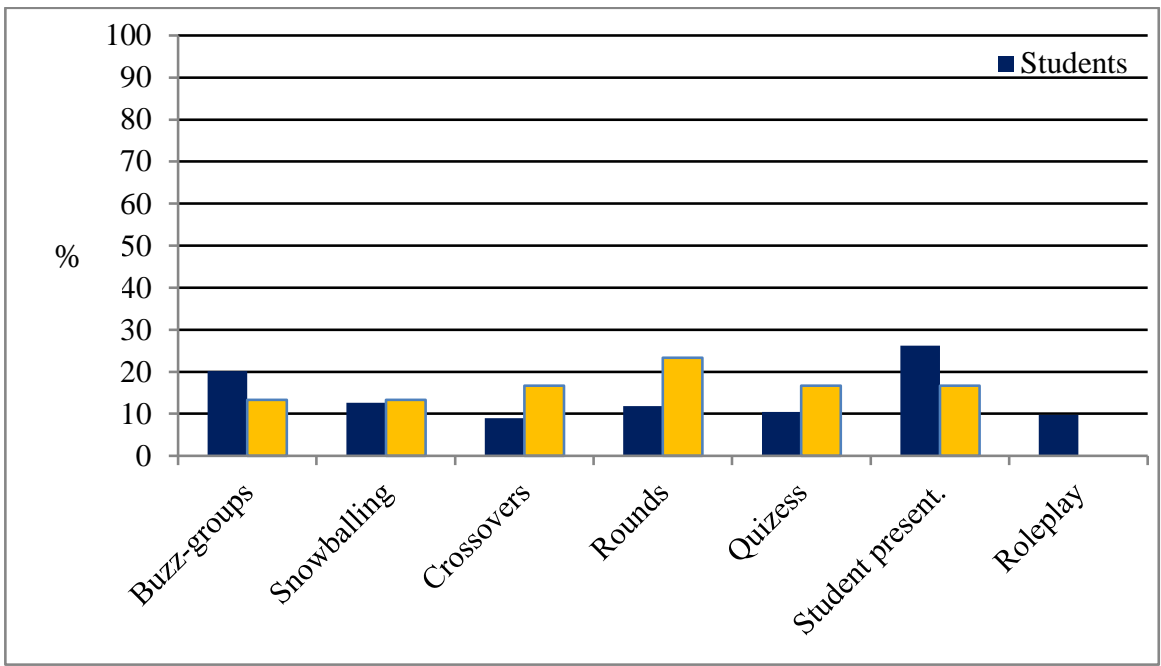

Figure 1: Teaching techniques utilized inside the lecture format

The results presented on Figure 2 show that there is a perfect match between the techniques used outside the lecture format by the teachers and the ones preferred by the students. The team work, independent projects and group discussions are the most preferred techniques by the teachers and students indicated that active and collaborative learning styles are being greatly implemented on the business and management courses at the faculty. 
A. Vasiljevic-Shikaleska, M.Stojanovikj, Z. Kirovska, M. Kiselicki \& B. Gjozinska: The Quest for Optimal Fusion of Learning, Teaching and Evaluation for Improving Student

Classroom

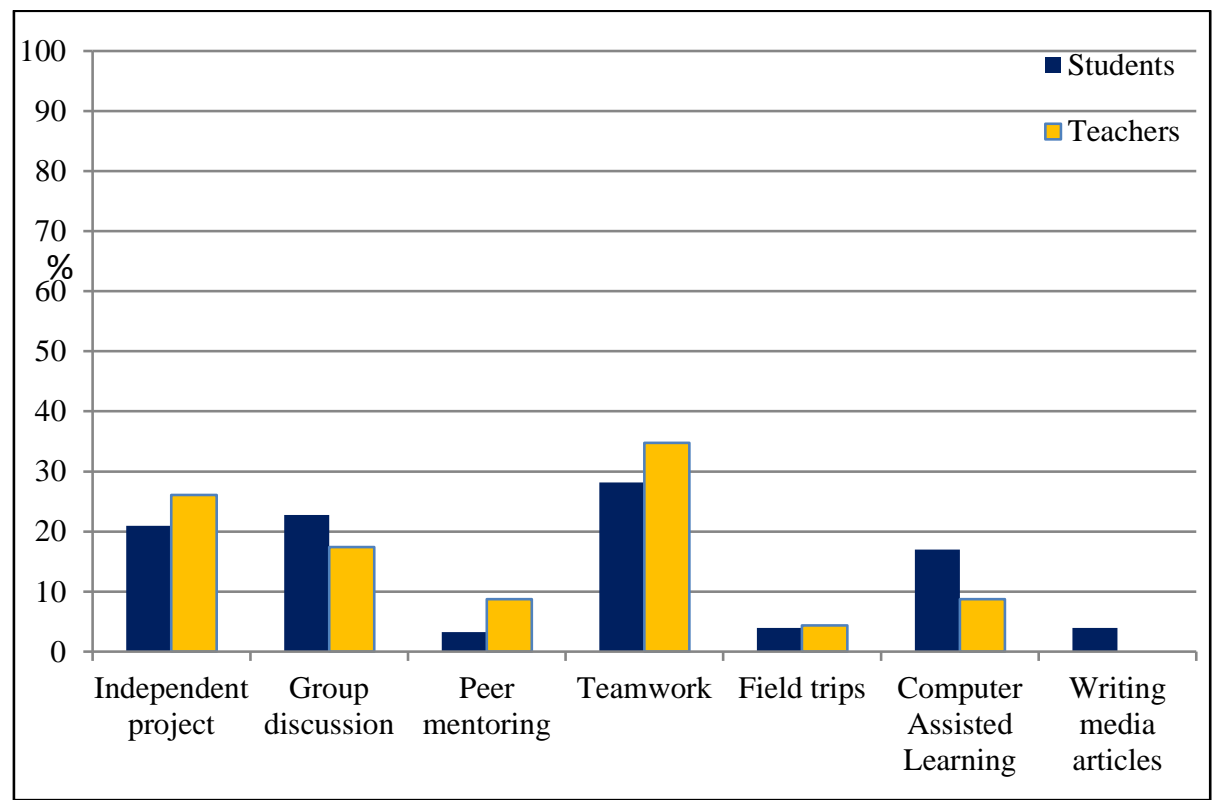

Figure 2: Teaching techniques utilized outside the lecture format

Additionally, students said that introducing more case studies, practical work, internet reading and internship would improve their specific knowledge and skills.

\subsection{Types of assessment methods utilized for evaluation of students' knowledge and understanding}

Concerning the results obtained for the assessment methods it can be summarized that traditional summative approaches of assessment (paper - and - pencil) was usually utilized. Both respondent groups, the students and the teachers, agree that the most used methods of examination are essays and multiple choice questions whereas the least used method is open-book examination.

From students point of view the most commonly practiced assessment methods are essays (written examination) and multiple choice questions followed by demonstration of practical skills and oral examination (Figure 3). 
$1^{\text {ST }}$ INTERNATIONAL SCIENTIFIC CONFERENCE »TEACHING METHODS FOR ECONOMICS AND BUSINESS SCIENCES «

A. Vasiljevic-Shikaleska, M.Stojanovikj, Z. Kirovska, M. Kiselicki \& B. Gjozinska: The Quest for Optimal Fusion of Learning, Teaching and Evaluation for Improving Student Classroom

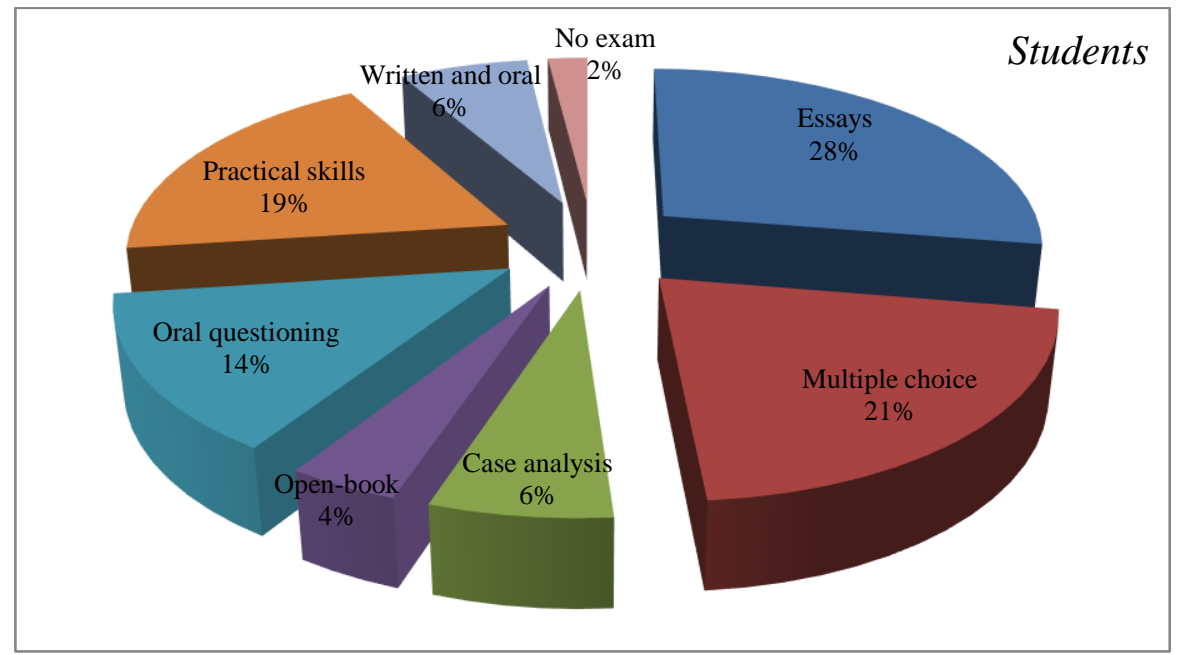

Figure 3: The most commonly used assessment methods by student' opinion

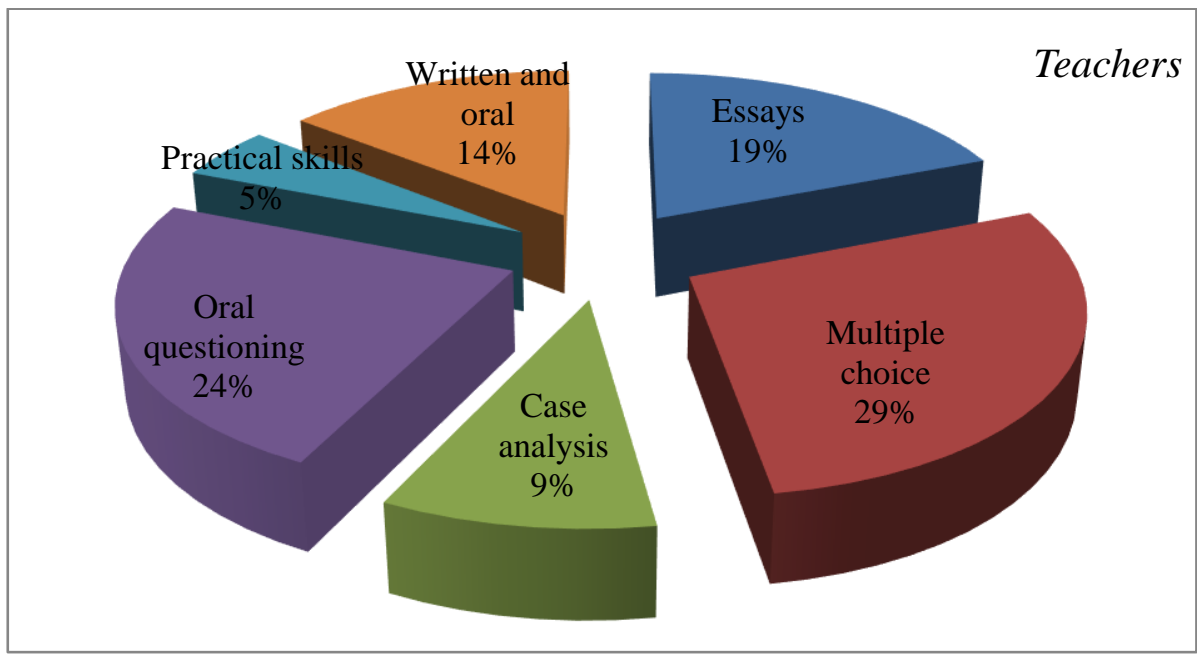

Figure 4: The most commonly used assessment methods by teachers' opinion

According teachers' responses, multiple choice questions, oral examination and essays are usually utilized. The teacher emphasize that oral examination is extremely important because paper-and-pencil tests tend to produce students who are test-smart but poor problem solvers in real situations and on the other hand students seem to lack in communication and other soft skills including social ones. Although assessment is still used in grading students based on their performances, worldwide there is a growing 
A. Vasiljevic-Shikaleska, M.Stojanovikj, Z. Kirovska, M. Kiselicki \& B. Gjozinska: The Quest for Optimal Fusion of Learning, Teaching and Evaluation for Improving Student Classroom

realization that it should be used to facilitate learning and skills development of students and to motivate them to perform better.

\section{Conclusion and recommendations}

In this study, a research of the preferred learning styles of students and the manner materials are being presented in the classroom was carried out.

Several teaching methods and techniques inside and outside of the lecture format were analyzed, from two points of view (students and teachers), in terms of their importance and utilization on the business and management courses at the Integrated Business Faculty in Skopje (R. Macedonia).

It was observed that students prefer utilization of practical exercises with real business data, seminars and tutorials as the most appropriate methods for gaining specific knowledge. On the other hand, teachers think that problem based learning, in addition to practical exercises and seminars, is also very beneficial teaching and learning method.

The in-class shift of lectures from teacher-centred to student-centred along with the team work, independent projects and group discussions, as outside activities, foster the active and collaborative instead of the cooperative learning style.

Assessment of students' performance and abilities accurately and reliably has always been a challenge. Our results implied that usually summative assessment method was used for assessing students' overall achievement. Teachers and students opinion is that the introduction of open-book examination, oral examination and analysis of cases/data/texts in addition to the commonly practiced summative assessment methods would contribute towards more accurate evaluation of students' knowledge.

The previously mentioned observations provide valuable information concerning the gaps identified in the utilization of teaching, learning and assessment methods on the business and management courses at the faculty. Based on our findings, we would recommend:

- Greater utilization of problem based learning, case studies and business simulations.

- Greater involvement of students during the lectures, particularly by making presentations on topics related to the respective course, or participating in the design of the lectures.

- Peer mentoring and tutoring as a helpful alternative to the traditional lecturing format in order to help students' present ideas in a more comprehensible manner.

- Formative evaluation of students' activity in the classroom and peer evaluation among students. 


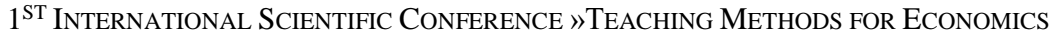
AND BUSINESS SCIENCES «

A. Vasiljevic-Shikaleska, M.Stojanovikj, Z. Kirovska, M. Kiselicki \& B. Gjozinska:

The Quest for Optimal Fusion of Learning, Teaching and Evaluation for Improving

Student Classroom

\section{Acknowledgement}

The research was conducted within the framework of Erasmus+ programme under the action KA203, Project No. 2014-MK01-KA203-000275 "Innovative Strategic Partnership for European Higher Education" (ISPEHE).

\section{References}

Alhussain, A. M. (2012). Identifying teaching style: The case of Saudi college English language and literature teachers. English Language Teaching. 5(8), 122-129.

Altun, F., \& Yazici, H. (2010). Learning styles of the gifted students in Turkey. Procedia-Social Behavioral Sciences, 9, 98-202.

Belk, J. A., \& Calais, G. J. (1998). Portfolio assessment in reading and writing: Linking assessment and instruction to learning. Paper presented at the annual meeting of Mid-South Educational Research Association, New Orleans, November 10-12, 1993. Retrieved from https://eric.ed.gov/?id=ED365732

Bidabadi, F. S., \& Yamat, H. (2010). Learning style preferences by Iranian EFL freshman university students. Procedia-Social and Behavioral Sciences, 7, 219-226.

Cano, J., Garton, B. L., \& Raven, M. R. (1992). The relationship between learning and teaching styles of student performance in a Methods of Teaching Agriculture course. Journal of Agricultural Education, 33(3), 16-22.

Cassidy, S. (2004). Learning styles: an overview of theories, models, and measures. Educational Psychology, 24(4), 419-444.

Dekker, S., Lee, N. C., Howard-Jones, P., \& Jolles, J. (2012). Neuromyths in education: Prevalence and predictors of misconceptions among teachers. Frontiers in Psychology: Educational Psychology, 429, 1-8.

Dinol, S., Temel, S., Oskay, O. O., Erdogan, U. I., \& Yilmaz, A. (2011). The effect of matching learning styles with teaching styles on success. Procedia-Social and Behavioral Sciences, $15,854-858$.

Fry, H., Ketteridge, S., \& Marshal, S. (2009). A Handbook for teaching and learning in higher education: Enhancing academic practice. New York: Routledge, Taylor\&Fransis group.

Garton, B. L., Spain, J. N., Lamberson, W. R., \& Spiers, D. E. (1999). Learning styles, teaching performance and student achievement: A relational study. Journal of Agricultural Education, 40(3), 11-20.

Larkin, T. (2003). Learning style in the classroom: A research guided approach. In Proceedings of the International Conference on Engineering and Computer Education (ICECE 2003), Session ETIB (pp. 1-8). Sao Paolo: Brazil. Retrieved from http://citeseerx.ist.psu.edu/viewdoc/download?doi=10.1.1.595.3391\&rep=rep1\&type=pdf

Othaman, N., \& Amiruddin, M. H. (2010). Different perspectives of learning styles from VARK model. Procedia - Social and Behavioral Sciences 7, 652-660.

Rogowsky, B. A., Calhoun, B. M., \& Tallal, P. (2015). Matching learning style to instructional method: Effects on comprehension. Journal of Educational Psychology, 107(1), 64-78.

Sternberg, R. J., Grigorenko, E. L., \& Zhang, L. F. (2008). Styles of learning and thinking matter in instruction and assessment. Perspectives on Psychological Science, 3(6), 486-506.

Tulbure, C. (2012). Investigating the relationships between teaching strategies and learning styles in higher education. Acta Didactica Napocensia, Vol. 5(1), 65-74.

Vaughn, L., \& Baker, R. (2001). Teaching in the medical setting: balancing teaching styles, learning styles and teaching methods. Medical Teacher, 23(6), 610-612 
A. Vasiljevic-Shikaleska, M.Stojanovikj, Z. Kirovska, M. Kiselicki \& B. Gjozinska: The Quest for Optimal Fusion of Learning, Teaching and Evaluation for Improving Student

Classroom

Visser, S., McChlery, S., \& Vreken, N. (2006). Teaching styles versus learning styles in the accounting sciences in the United Kingdom and South Africa: a comparative study. Meditari Accountancy Research. 14(2), 97-112. 
$196 \mid 1^{\text {ST }}$ InTERnational SCIENTIFIC CONFERENCE »TEACHING METHOdS For ECONOMiCS AND BUSINESS SCIENCES« 


\title{
Teaching Methods to Support Creative Environment
}

\author{
ZDENKA ŽENKO
}

\begin{abstract}
Teaching in economic and business disciplines includes developing creativity. The intercultural dimension, interconnectedness through social networks and accessibility of on line courses demands greater adaptability of university teachers, to requisitely manage the complexity in more global community. Innovating is the focus of modern societies and this strategic priority of societies and individuals is based on creativity. Creativity can be fostered by encouraging the lateral and divergent way of thinking. Six thinking hats method of De Bono encourages such thinking and it should be purposefully combined with other methods. Communication among members is vital not only to describe the idea but through the whole invention-innovation diffusion process. Therefore, teacher's role became not only to offer knowledge for their future social or professional roles but also to prepare teaching methods to develop creative environment in the classroom for more international or internationally active millennia students.
\end{abstract}

Keywords: $\cdot$ creativeness $\cdot$ innovations $\bullet$ teaching methods $\bullet$ stress $\bullet$ communication •

CoRrespondence AdDress: Zdenka Ženko, Ph.D., Professor, University of Maribor, Faculty of Economics and Business, Razlagova ulica 14, 2000 Maribor, Slovenia, e-mail: zdenka.zenko@um.si. 
$1^{\text {ST }}$ INTERNATIONAL SCIENTIFIC CONFERENCE $\gg$ TEACHING METHOdS FOR ECONOMICS AND BUSINESS SCIENCES"

Z. Ženko: Teaching Methods to Support Creative Environment

\section{Introduction}

Teaching in economic and business disciplines is mostly about learning theoretical explanations, approaches, and more practical case studies. Due to the development of both theory and practice in global environment, this task is very challenging. When knowledge and experience are combined with intellectual capacity of finding new concepts, ideas, solutions, we are developing creativity. The essence of modern world might be the knowledge how to understand the possibilities and needs of our societies. The most important factor for the success of companies or the economy is the knowledge how to use the information, also the information communication technology (ICT), how to select and determine what goals to reach and to manage and to develop the ambition for achieving continuous innovation for excellent quality (Ženko, 1999, p.1). These basic needs have not changed much, society has.

As business teachers, we are preparing our students for their and our future. Not only we give them theories on specific subjects, we also support them in developing their strategy as a direction of their personal and professional life. Strategy should be understood here with the dynamic concept, including the advancement of young professionals developing their competitive strength for tomorrow. As companies or societies, also young professionals need to establish what they want to become in their life - like a vision statement. They have to recognize the valuable goals and select what they want to achieve, like a mission statement with a plan of performance goals. As researchers, teachers and mentors we can help them during the process: "How will we get there?", by facilitating their intellectual growth, to select their priorities and offer them guidelines for their personal and professional development.

Based on data from Credit Suisse for 2015, Treanor (2015) reports that half of the world's wealth is now owned by $1 \%$ of world's citizens. Before the 2008 crisis, it was owned by $2 \%$. Only $14 \%$ of adults worldwide are middle class with USD 50,000 to 500,000 of personal wealth (savings, properties, pension plans, and other assets).With having only USD 68,800 , one is among the $10 \%$ of the richest. Zumbrum (2016) calculated from Federal Reserve data for the USA in 2015 that, on average, a 20-year-old person in the USA has USD 0 in personal wealth, a 30-year-old average person has USD 98,000, and a 40-year-old already has USD 308,000 in personal wealth.

We know from different sources that many professions of today are already endangered by technological advancement (ICT, robotics, self-driving cars, etc.). There are also predictions that only the more educated persons (those holding a master's degree and above) can expect relative increase of their salaries. Thus, we see less job openings, longer working years and salary increase mostly for the more educated ones. Inflation in Slovenia $2008-2016$ was $12 \%$ and net salaries increased around 17\%. With 5\% (or EUR 50) real growth in 8 years, we can speak of the stagnation of real income. With longer work period and lower retirement compensations, many employees hardly manage their financial stress. Todurov (2016) reports on a recent study from 2015 that only $3 \%$ of Slovenes know basic rules of investing and only $6 \%$ know how to manage savings. More 
than $90 \%$ of Slovenes do not have enough knowledge to manage their finances and prepare for their future needs. PricewaterhouseCoopers (2017) reports that 3 hours per week are spent for managing personal finances during working time, or two weeks yearly.

As professions will change or disappear, so will the businesses. If an employed adult in the EU can expect to change the employer 5 times during one's working period, so can younger generation expect to change not only employers but also working areas or professions.

Our students experience globalism and great quantity of information as the abundance of possibilities. It might be more difficult to select the right goals for future personal and career development. A few decades ago, university graduates used to find well paid employment quite easily. The middle class now amounts only to $14 \%$ and is predicted to be even smaller in the future. The salaries with real growth are predicted only for the most educated ones. And saving for health insurance and pension presents considerable stress already for the working population. Knowledge as can be taught might not be sufficient. But if we teach students to become creative and innovative, their potentials for better life are greater.

Innovating is the focus of modern societies. Dyer et al. (2011, p.1) discuss the innovation as the strategic priority for virtually every company. Precondition of innovations is creative environment were ideas can develop into useful solutions of meaningful needs. The IBM research (IBM, 2010) of fifteen hundred CEOs recognized that creativity is the number one leadership competency of the future. Creativity has become more important due to the above described viewpoints.

\section{$2 \quad$ Preconditions for innovating}

\subsection{Creativeness}

The importance of learning process relates to the (prolonging) duration of time spent in different schools by the majority of citizens. We start our formal education very young in our formative age and become socially modified for many years. Learning process includes also mental development, understanding, reasoning, communication and decision making. As teachers, we are developing students' knowledge also at the theoretical, methodological and practical basis. We also need to promote such values, norms, culture and ethics to support the development of individuals as creative members of local and global societies.

The creativity of preschool children is very high. Preschool teachers in Slovene public preschool care are encouraging, developing and supporting children to express themselves in many areas. In elementary schools, the development of creativity is still in focus during the first years, but later the more rigorous learning replaces more creative subjects. Educational systems should encourage the development of attitudes for functioning in the society, work related values and communication skills. We should also 
encourage the development of passion for the search for new knowledge, creativeness, individuality of each person and respect for other beings. We should also promote learning of communicating, cooperating in groups, and ethics of interdependence. Students should master to clearly describe their ideas, honestly express their personal opinion, reason their position, and present their decisions.

But in Slovenia, by the time they become students, they mostly prefer to listen than talk. Although I often stress how important communicating is in innovating, the majority of students seldom present their opinions. They need a lot of encouragement before they openly discuss different viewpoints. I introduced active participation as a method of teaching in all my courses. If a class is too big, they may exceptionally also submit their opinions as notes on paper or e-mails after class. My grading system includes 10\% to 20\% of the final grade for active participation during lectures.

Oral presentations, as a way to participate in class, support the communication among the millennia students who are more used to short texting on mobile phones than thoroughly expressing their ideas, beliefs and thoughts. Students, as well as elementary school pupils, state stress as an important hindering factor in their learning process as well as life (Ženko \& Marn, 2014). Tertinek et al. (2017) presented the high stress factors for students at FEB: speaking in class as part of active participating; deadlines for seminar papers, tests and exams; orally presenting their seminar papers in the classroom; general pear pressure among youngsters; social contacts with different sex.

To advance their communication, cooperation and management skills, my students at FEB work on semester research papers in groups. In international courses, groups should include members from different countries, in Europe this often means from different cultures. Groups present their seminar research in class and also lead the discussion. With this work, they can earn $40 \%$ of the final grade. Seminar research project includes theory from our lectures applied to a practical case or society, with their own comments, critics, ideas, models, etc. The third part of their grade is an individual written exam, where $20 \%$ of points are allocated for theoretical responses and $20 \%$ for the description of how this theory works in practical case. Excellent grades are reserved for the students with more holistic answers and more original cases.

There are some students who tell me that this is their first course where they can really participate in the learning process and express their personal opinion. Due to their previous experiences in educational systems, it takes me few weeks before we build a nurturing, safe, trusting and creative learning environment. At the end of the semester, many students state that being allowed to participate and also being critical during the learning process is very rewarding for them.

\section{$3 \quad$ Phases of creative processes and ways of thinking}

Creativity is a complemental and social process. So is creating a creative environment. A part of our class environment was described above. The discussion part, comments, 
critics, their own ideas, many cases, longer seminar research group paper were included to foster five for creativity important features: non-conformism, flexibility, originality, perseverance and team cooperation.

For creativity, non-conformism represents a source of unique ways of perceiving the objective reality. Students are encouraged to disagree with me, but they are asked to state the sources of the data they present or authors of the theory that they find more relevant. Flexibility needs to be encouraged and supported during the invention process when to fail or have difficulties is a natural path of discoveries. Originality here represents unique solutions, combinations or inventor's step. They can be fostered by encouraging the lateral and divergent way of thinking.

Idea creating process could be presented, studied and managed in four basic stages: 1 . Preparation is hard analytical work. 2. Incubation or stand still means material will be consciously and unconsciously processed by our brains. 3. Illumination is a great moment when perfect solution appears. In this stage lateral thinking is crucial. 4. Verification stage should give answers to: can we produce this great solution and it is used as beneficial. This verification stage takes a lot of time and many co-workers from different areas of specializations should participate. This last stage of idea creating process requires analytical work again.

As we can observe different stages of idea creating process, so we can observe different ways of thinking. Vertical and convergent ones are quite common in western European cultural education system. Divergent thinking is known, but is not supported enough in the education system. The least imbedded in our education of economists and managers is lateral thinking. Illumination phase without well-developed lateral thinking is severely hindered.

To develop creativity, we need to use and combine all four ways of thinking. We can apply methods of creative thinking and decision making which support learning of lateral and divergent ways of thinking. These two ways are less common in educational process than convergent and vertical way of thinking.

\section{Some methods to support creative thinking}

We can select among more than hundred creative thinking methods. For each method, we need to build theoretical understanding of the purpose, aim, duration and limitations, etc. The second success factor is the practical experience of applying a certain method. The third factor is the selection of a combination and sequence order of chosen methods. Like a person leading the brainstorming session, so the skilled person selecting and leading the mix of methods is required for a successful creative process. Not only methods support the search for creative solutions or innovative ideas. People participating in creative methods develop their way of thinking. De Bono's (1999) 'Six thinking hats' method encourages lateral thinking. Under the red hat we may express emotions, too. Under the black hat, we may express doubts, negative thoughts fear. When we use the 'Six thinking 
$1^{\text {ST }}$ INTERNATIONAL SCIENTIFIC CONFERENCE »TEACHING Methods FOR ECONOMICS AND BUSINESS SCIENCES«

Z. Ženko: Teaching Methods to Support Creative Environment

hats' method every member of the group is allowed and expected to think and present his opinion under each hat. Classical corporate meeting is more like as follows: CFO focuses only on finances, and if you are not from the production, you are not qualified to discuss production problems. Also position, seniority, hierarchy, specialization, are not playing a significant role among participants of the 'Six thinking hats' method.

Creative thinking should be purposefully supported and combined with other methods like USOMID, ABC, Delphi, Designer thinking, Fish bone.

The methods are well described in other publications, so in this paper we will only briefly introduce their main objectives.

\section{1 'Six thinking hats' method}

Edward DeBono (1999) designed this method to encourage and allow people participating in a group to think and discuss the object under consideration from different viewpoints. This is a very unusual practice in organizations. Imagine a session in a court where the plaintiff, the defendant and the judge are equally trying to find the truth. People are, due to their specialization, hierarchical position, organization, age, and gender, etc., unable to express their honest opinion or state all the information they have or might be able to acquire. With 'Six thinking hats', we move from such common way of thinking and decision making to a more holistic and participative one. We use six imaginary hats of different colors. Under each hat, only a specific type of ideas, opinions, questions, and data might be stated, but everyone is invited to participate. For example, we first use a blue hat under which everybody in the group should say something about the objective of gathering, facts, information, data, and similar. Other hats are white, red, black, yellow, green and the concluding or final blue hat. Under red hat we can express emotions, fears, suspicions and intuitions. No data or reasoning is required. Just "I feel that..." is enough for the opinion to be presented and taken into consideration by the group. For creativeness and innovativeness, the yellow hat is also interesting and valuable. Under the yellow hat, group members can be very optimistic, positive, and can discuss all the possible benefits of the issues discussed. 'Six thinking hats' allow us to stay focused during the discussion from many different viewpoints. Each person is encouraged to think and state their specialist knowledge, opinion or emotions and fear, or doubts under the specific hat.

\subsection{Design thinking}

Design thinking can be described as a systematic methodology or a philosophy, strategy of creating solutions for users. It includes three processes: understand, explore and materialize. At Stanford University, doctoral school classes are offered to their enrolled students as well as to other interested individuals from public, academic or entrepreneurial organizations (https://dschool.stanford.edu/classes/). In teaching creative thinking, we can use this method as a method with 5 stages: empathize, define, ideate, prototype and test. Students can form a group and work through these stages. First, they select a problem or an area where they want to search for a creative solution. Later in the first stage, they 
think as a user - how the problem appears to the user. So the innovative process includes the users from the earliest stages of designing solutions for them. In class, they develop simple models, prototypes with paper, plastic, cardboard, colors, paperclips, etc. After testing, they re-design several prototypes in a few hours.

Design thinking can be seen as a philosophy, as an open source innovating process. It is also a combination of creative methods applied during the design process. Students also need to apply knowledge and practical experience from other courses and can benefit from the skills developed in their personal life.

\section{The findings and conclusions of the paper with thoughts and suggestions for further research / implication for teaching practice}

The accumulation of wealth in the minority of $1 \%$ and their control or power presents a threat for sustainable development. It might be a greater threat for the younger generation. As a group, they are most creative, educated, they know how to use communication tools and social media. They might be globally more open and tolerant of different cultures. If we develop their creativeness and knowledge of innovative management, they will be more successful in introducing social changes.

Creativity can be nurtured in supportive creative environment. It is an individual's mental capacity. For them to present their ideas, we should support our students in learning how to communicate and to cooperate in groups as well as the ethics of interdependence. Students should master the ability to clearly describe their ideas, to honestly express their personal opinion, to reason their position, and to present their decisions.

In companies and societies, we can select proper mix of creative thinking methods. Not only we develop a creative thinking team, we change the creative culture and the ways of thinking and perceiving our objective realities needs and possibilities. For ideas to develop into innovations, the cooperation in groups of versatile specialists assures the requisite variety.

\section{References}

De Bono, E. (1999). Six thinking hats. New York: Back Bay Books.

Stanford University. (n.d.) Design thinking crash course. [Online video] Retrieved from https://dschool.stanford.edu/resources/virtual-crash-course-video

Dyer, J., Gregsen, H. \& Christensen, C. (2011).The innovator's DNA. Boston, Massachusetts: Harvard Business Review Press.

IBM. (2010). Capitalizing on complexity: Insights from the global chief executives officer study. Somers, USA: Author.

Plattner, H., Meinel, C., \& Leifer, L. J. (Eds.). (2011). Design thinking: understand, improve, apply. Understanding innovation. Berlin; Heidelberg: Springer-Verlag.

PricewaterhouseCoopers. (2017). 2017 Employee financial wellness survey. Retrieved from https://www.pwc.com/us/en/private-company-services/publications/financial-well-beingretirement-survey.html 
Z. Ženko: Teaching Methods to Support Creative Environment

Stanford University. (n.d.) Design thinking course. Retrieved from https://dschool.stanford.edu/classes

Tertinek, Z., Ban D., Kamenik, D., \& Gorjup A. (2017). Stres. (Unpublished seminar paper for Innovation Management course, winter semester of 2016 - 2017). University of Maribor, Faculty of Economics and Business, Slovenia

Todurov, M. (2016, December 1). Finančni stress je največji dejavnik stresa pri posameznikih. Svet kapitala. Retrieved from http://svetkapitala.delo.si/finance/visoka-cena-financnega-stresa$448 \#$

Treanor, J. (2015, October 13) Half of worlds wealth now in hands of $1 \%$ of population - report. The Guardian. Retrieved from https://www.theguardian.com/money/2015/oct/13/halfworld-wealth-in-hands-population-inequality-report

Zumbrum, J. (2016, June 21) Not just the 1\%: The upper middle class is larger and richer than ever. The Wall Street Journal. Retrieved from https://blogs.wsj.com/economics/2016/06/21/notjust-the-1-the-upper-middle-class-is-larger-and-richer-than-ever/

Ženko, Z. (2013). Dilemmas of teaching socially responsible behavior to students. In: A. Hrast, M. Mulej, \& S. Kojc (Eds.). Education and Communication for More Social Responsibility: Conference Proceedings = Izobraževanje in komuniciranje za več družbene odgovornosti: zbornik prispevkov, sh $^{\text {th }}$ IRDO International Conference Social Responsibility and Current Challenges 2013 (6 pages). Maribor, Slovenia: IRDO.

Ženko, Z., \& Marn, S. (2014). Socially responsible behavior against stress in elementary school. In: M. Mulej, A. Hrast, \& S. Kojc, (Eds.), Health - Personal and/or Social Responsibility?: Conference Proceedings $9^{\text {th }}$ IRDO International Conference Družbena odgovornost in izzivi časa 2014 (8 pages). Maribor, Slovenia: IRDO.

Ženko, Z. (1999). Comparative analysis of management models in Japan, United States of America, and Western Europe (Unpublished doctoral thesis). University of Maribor, Faculty of Economics and Business, Slovenia. 

